\title{
MI
}
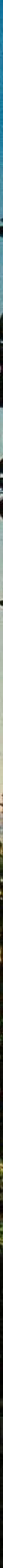


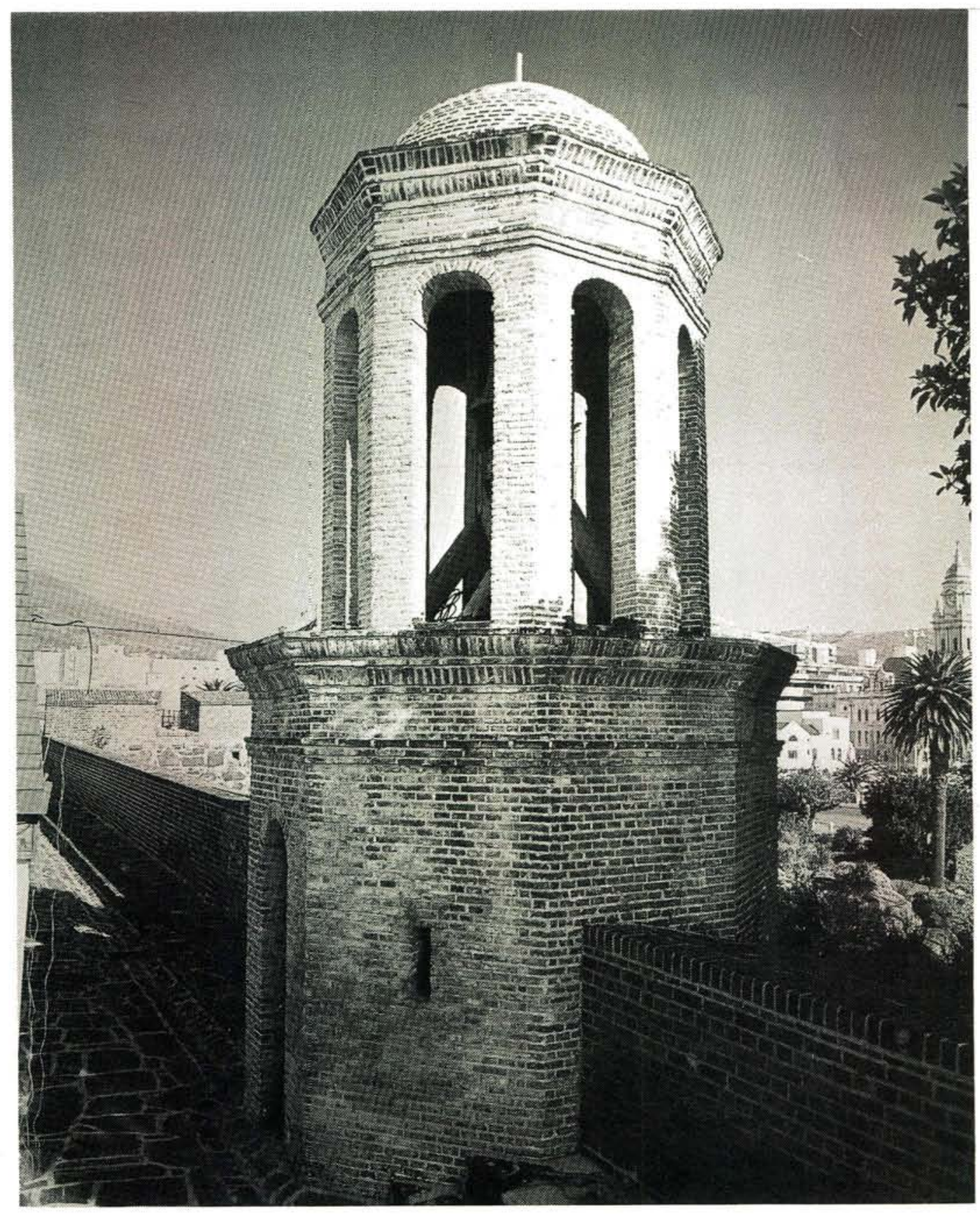

\section{Cover Picture}

The Belfry after Restoration

\section{Voorbladfoto}

Die Kloktoring na Restourasie 


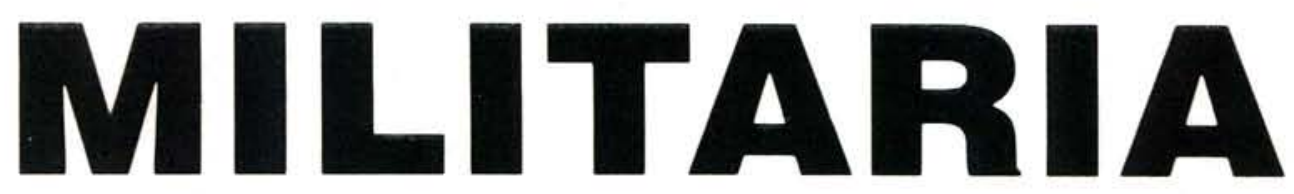

\section{Amptelike Vaktydskrif van die SAW}
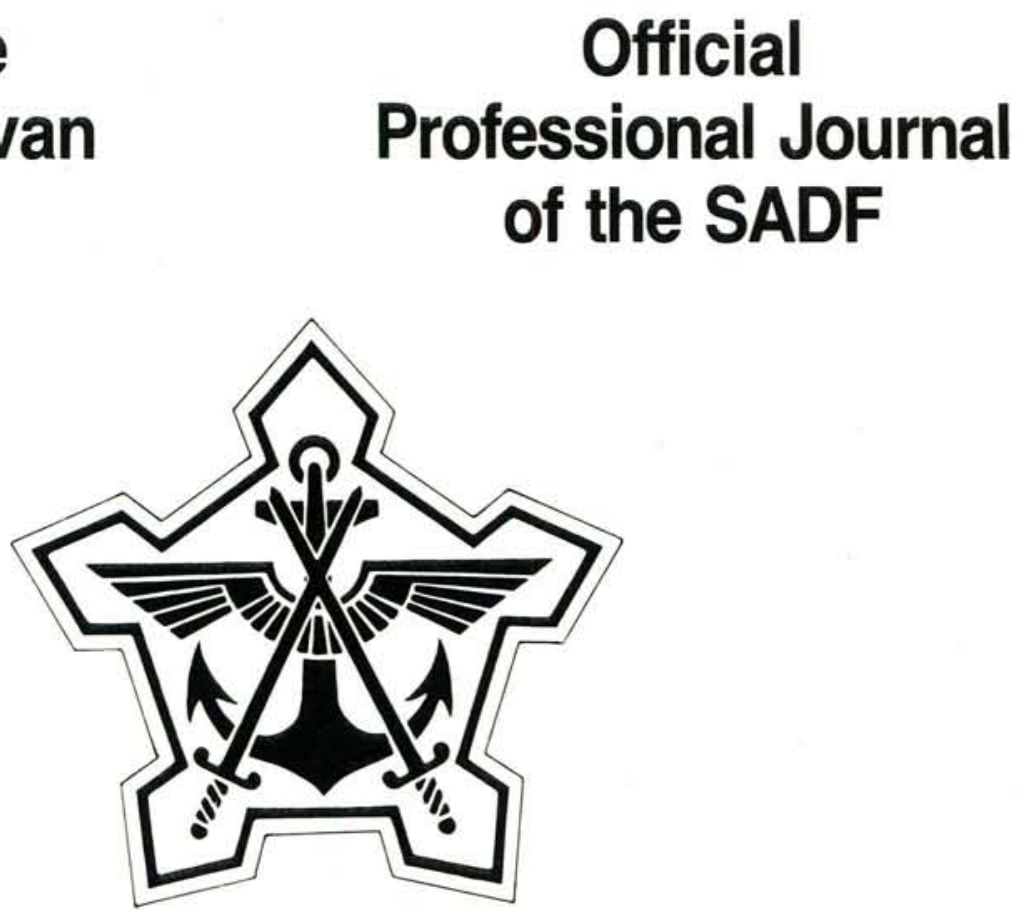

Redaksie

Militêre Informasieburo

SAW

Privaatsak X289

Pretoria
Edited by:

Military Information Bureau

SADF

Private Bag X289

Pretoria
MILITARIA is verkrygbaar by die Militêre Informasieburo, SAW, Privaatsak X289, Pretoria 0001, Suid-Afrika.
MILITARIA is available at the Military Information Bureau, SADF, Private Bag X289, Pretoria 0001, South Africa. 
Opinions expressed by individual contributors do not necessarily reflect the official viewpoint of the SADF.

Persoonlike menings in die loop van ' $n$ artikel uitgespreek, word nie noodwendig deur die SAW onderskryf nie. 


\section{Inhoudsopgawe/Contents}

\section{Editorial}

Redaksioneel

Introduction to the photograph collection; Castle of Good Hope Cdr W.M. Bisset Inleiding tot die fotoversameling: Kasteel de Goede Hoop Kdr W.M. Bisset

1. Historical Background

Historiese Agtergrond

The Castle of Good Hope/Die Kasteel de Goede Hoop Miss/Mej W.J.

Kroukamp

2. The Castle in later years

Die Kasteel in later jare

3. The Military significance of the Castle

Die Militêre betekenis van die Kasteel

4. The First World War

Die Eerste Wêreldoorlog

5. The Second World War

Die Tweede Wêreldoorlog

6. The Castle as Fortress

Die Kasteel as Vesting

7. Military Service and Training: post-war period Militêre Diens en Opleiding: na-oorlogse periode

8. The Castle as accommodation for Governors, Commanders, officers and troops

Die Kasfeel as huisvesting vir Goewerneurs, Bevelvoerders, offisiere en troepe

9. Visitors

Besoekers

10. The No. 1 Military District and Cape Command Visitors books 1919-1957 $\mathrm{Kdr} / \mathrm{Cdr}$ W.M. Bisset

11. Functions held at the Castle

Funksies gehou in die Kasteel

12. Herdenkings en sosiale geleenthede

13. Awarding of Medals, Decorations and Honours Toekennings van Medaljes, Dekorasies en Eerbewyse

14. The Dark Hole/Die Donker Gat Lt A.M. Le Roux

15. Prison

Gevangenis

16. The Castle's Museums

Die Kasteel se Musea 


\section{Redaksie/Editorial Staff}

Besturende Redakteur Managing Editor

: $\quad$ Maj J.Y. Erasmus

Uitvoerende Redakteur/ Executive Editor

: Lt A.M. Le Roux

Fotografiese Redakteur Photographic Editor

: Lt Kdr/Lt Cdr E.M. Meyers

Medewerkers/Co-Workers : Mej/Miss W. Kroukamp Mnr/Mr J.A. Visser 


\section{EDITORIAL}

The Castle in Cape Town is undoubtedly the oldest landmark in the history of South Africa, that has been preserved for the present and coming generations. Now, 319 years after the cornerstone for the building of the Castle was laid, the restoration of this historical fortress is already in full swing. In 1986 it will be closed temporarily to facilitate further restoration work and when it reopens, one will be able to view the Castle in all its old splendour.

The closing of the Castle coincides with the moving of the Maritime Museum to a more appropriate place in the old Victoria tidal basin in Table Bay. The relocation of the Maritime Museum, which was established in the Castle in 1971, is necessitated by the restoration work on the Castle. The relocation of the Maritime Museum in the harbour of Table Bay will revive the historical importance of the area and will assist in restoring Cape Town's historical link with the sea. At the new venue, the Maritime Museum will be able to accommodate considerably more memorabilia.

To date the Maritime Museum has been run by the SA Defence Force Museum Service assisted by the National Maritime Museum Trust. The control of the Museum will now pass to a civilian body. The SADF Museum Service will retain certain items relating to South Africa's naval history which will be displayed in a SA Naval Museum to be established in the grounds of Fort Wynyard in Green Point.

This edition of Militaria is dedicated entirely to the origin and history of the Castle. The interesting illustration material included herein, brings the role that the Castle played in the military history of the Republic of South Africa, clearly to the fore.

\section{REDAKSIONEEL}

Die Kasteel in Kaapstad is ongetwyfeld die oudste landmerk in die geskiedenis van SuidAfrika, wat vir die huidige en komende geslagte behoue gebly het. Nou, 319 jaar nadat die hoeksteenlegging vir die bou van die Kasteel gelê is, is die restourasie van hierdie historiese vesting reeds in volle swang. In 1986 sal dit tydelik ges/uit word om verdere herstelwerk te vergemaklik en wanneer dit weer oopgestel word, sal die Kasteel ten volle in sy ou glorie besigtig kan word.

Die sluit van die Kasteel val ook saam met die verskuiwing van die Maritieme Museum na 'n geskikter plek in die Ou Victoria-getykom in Tafelbaai. Die verskuiwing van die Maritieme Museum wat in 1971 in die Kasteel gevestig is, word genoodsaak deur die restourasiewerke aan die Kasteel. Die hervestiging van die Maritieme Museum in die hawegebied van Tafelbaai sal die historiese belangrikheid van die gebied laat herleet, en daartoe meehelp om Kaapstad se historiese verbintenis met die see in ere te herstel. In sy nuwe tuiste sal die Maritieme Museum heelwat meer gedenkwaardighede in sy versameling kan huisves.

Tot op hede is die Maritieme Museum deur die Suid-Afrikaanse Weermag se Museumdiens, bygestaan deur die SA Nasionale Maritieme Trust, bedryf. Die beheer van die museum sal nou aan 'n burgerlike instansie oorgedra word. Die SA Museumdiens sal egter sekere items wat op die vlootgeskiedenis van Suid-Afrika betrekking het, behou vir opname in die SA Vlootmuseum wat by Fort Wynyard (Groenpunt) opgerig gaan word.

Hierdie uitgawe van Militaria word ten volle gewy aan die ontstaan en geskiedenis van die Kasteel. Uit die interessante illustrasiemateriaal wat hierin opgeneem is, kom die rol wat die Kasteel in die Republiek van Suid-Afrika se krygsgeskiedenis gespeel het, duidelik na vore. 


\section{AN INTRODUCTION TO THE PHOTOGRAPH COLLECTION: CASTLE OF GOOD HOPE}

\author{
by Cdr W.M. Bisset (SO1, SADF \\ Museums Service)
}

The Castle of Good Hope in Cape Town is South Africa's oldest and most important historical monument, so one would expect that many photographs depicting its history would be readily available. Unfortunately this is not the case and there are a number of gaps in this collection.

The most important collection of early photographs of the Castle is that assembled by the Cape Archives. Most of the photographs were taken by Mr Arthur Elliott between 1900 and 1914. They provide us with a vivid picture of the officers, men, women and children of the British Garrison and show the state of the building at that time. In some instances careful scrutiny reveals architectural embellishments which have since disappeared or makes it possible to read the painted signs over the doorways which indicate who occupied the room or rooms at the time.

Mrs Felicity Moore's photographs of the Castle, its Combined Operations Room and the personnel who manned it in the closing stages of the Second World War, fill a very important gap and are published for the first time.

It is hoped that the publication of this special edition of Militaria will lead to the discovery of more historic photographs of the Castle. Our debt to the photographers whose work has been included, is immense.

\section{INLEIDING TOT DIE FOTO-VERSAMELING: KASTEEL DE GOEDE HOOP}

\author{
deur kdr W.M. Bissef (SOI, SAW \\ Museumdiens)
}

Die Kasteel de Goede Hoop in Kaapstad is een van Suid-Afrika se oudste en belangrikste historiese monumente en 'n mens sou verwag dat baie foto's wat die geskiedenis daarvan uitbeeld geredelik beskikbaar sou wees. Ongelukkig is dit nie die geval nie en is daar aspekte wat nie deur die beskikbare foto's gedek word nie.

Die belangrikste versameling van vroee foto's van die Kasteel is die wat deur die Kaapse Argief byeen gebring is. Meeste van die foto's is geneem deur mnr Arthur Elliott tussen 1900 en 1914. Hulle bied ons ' $n$ duidelike prentije van die offisiere, manskappe, vroue en kinders van die Britse garnisoen en toon die toestand van die gebou op daardie tydstip. In sommige gevalle toon deeglike bestudering van die foto's argitektoniese versierings wat sedertdien verdwyn het of word dit moontlik om die geskilderde aanwysings bokant deuropeninge te lees, wat aandui wie die vertrek of vertrekke ten tye beset het.

Mev Felicity Moore se foto's van die Kasteel, sy gesamentlike operasies kamer en die personeel wat dit beman het in die finale stadium van die Tweede Wêreldoorlog, vul 'n baie belangrike leemte en word vir die eerste keer gepubliseer.

Dit word vertrou dat die publisering van hierdie spesiale uitgawe van Militaria sal lei tot die ontdekking van nog meer historiese foto's van die Kasteel. Ons is besondere dank verskuldig aan die fotograwe wie se werk inges/uit is.

Acknowledgements/Erkennings

The valuable help of the following is gratefully acknowledged

Akkersdyk Studios

Lt R. Appel

AO2NOO2 V.G. Barsdorf

Mnr/Mr R.H. Beard

$\mathrm{Mnr} / \mathrm{Mr} \mathrm{G}$. Borain

Kaapse Argief/Cape Archives

Cape Field Artillery

Cape Town Highlanders

Cape Town Rifles

Mnr/Mr W.G. Cooper

Kol/Col L.A. Crook, SM, JCD

$\mathrm{Mnr} / \mathrm{Mr} \mathrm{C}$. Danziger

Maj A.G.D. Gordon

Mnr/Mr Don Nelson

Mrr \& Mev/Mr \& Mrs G. Fagan 


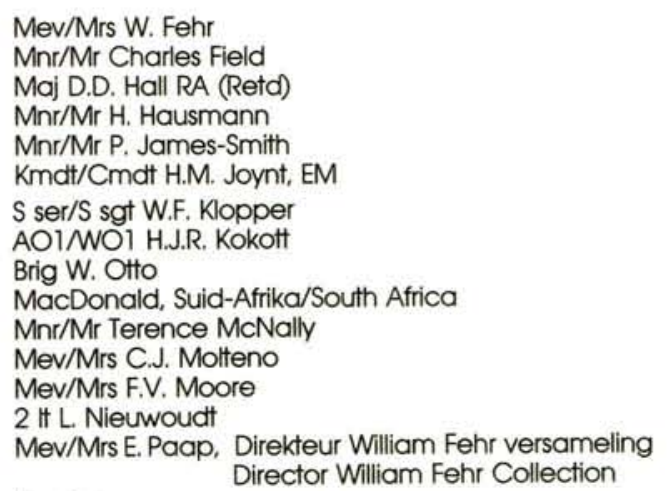

Paratus

WrrvPte A.V. Philcox

Mev/Mrs W.H.E. Poole

Mev/Mrs G.M. Prinsloo

Mev/Mrs E. Rausch

KoVCol D.C. Robertson, JCD

SAW Filmburo/SADF Film Bureau

SA Voot Drukeenheid/SA Navy Printing Unit

The Argus

The Cape Times

Uniform

Taylor's Studios Cape Town

Kommandement Westelike Provinsie/Western Province Com-

mand

AOINOI G.F. Wilson, PMM

The entire collection of photographs was made available to Militaria by Cdr W.M. Bisset (SO1 SADF Museums Service) and

the outlay and arrangement of photographs were taken care of by Lt Cdr E.M. Meyers (photographic editor, Militaria).

Die hele versameling foto's is aan Militaria beskikbaar gestel deur Kdr W.M. Bisset (SOI SAW Museimdienste) en die uitleg en ordening van die foto's is behartig deur Lt kdr E.M. Meyers (fotografiese redakteur, Militaria). 


\section{Historical background Building of the Castle}

\section{Historiese agtergrond Die bou van die Kasteel}

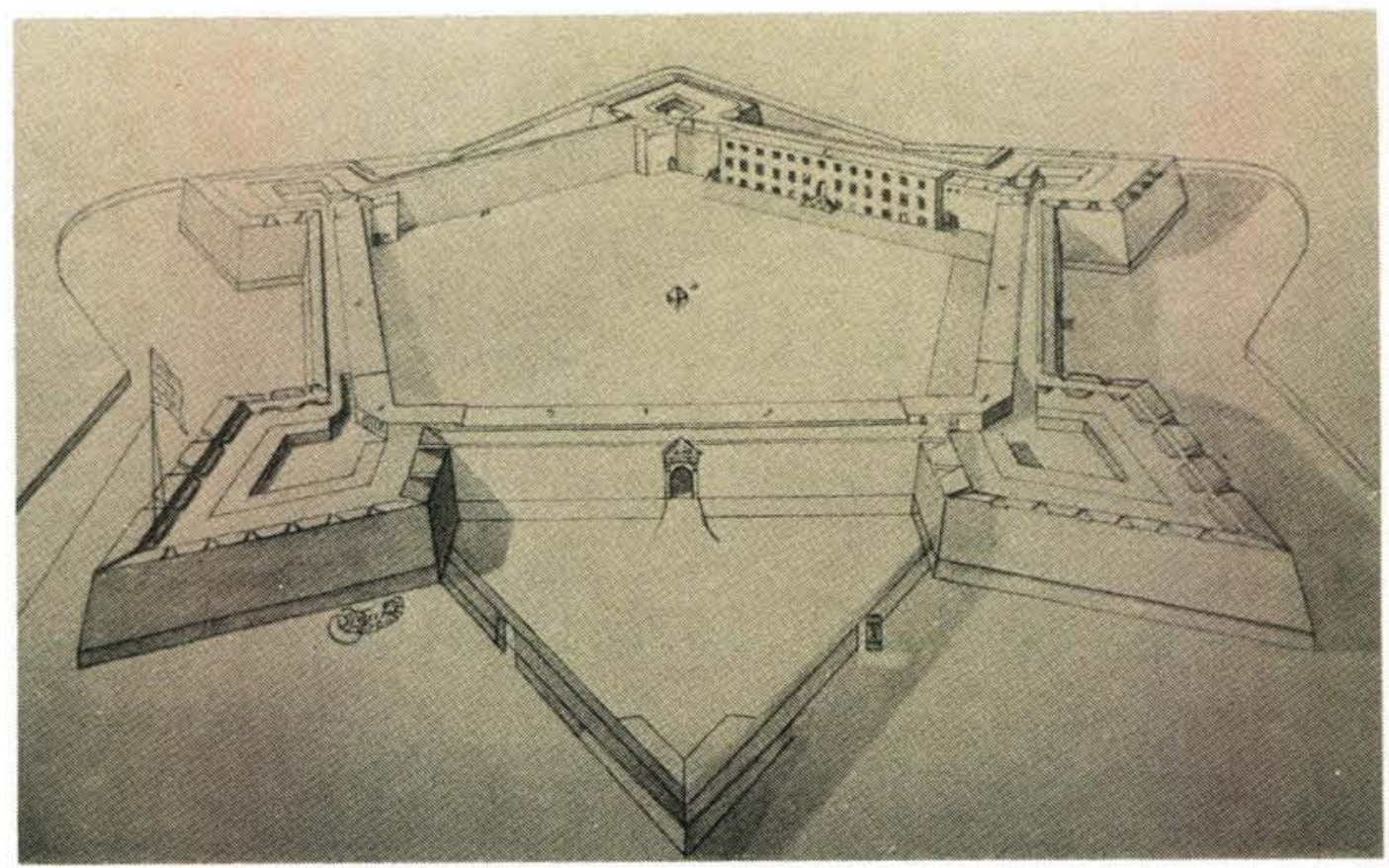

The Castle prior to the building of the Kat or curtain wall in 1695. The watergate midway between Katzenellenbogen and Buren bastions was replaced as the main entrance to the Castle when the Simon van der Stel gateway was completed in April 1684. Inaccessibility at high tide, defence problems and the sandy approach which was impassable to loaded wagons were among the considerations which necessitated this change. It was feared that the ravelin in

front of the watergate might be of greater use to the enemy than to the defenders. In the centre is the well. Between the Oranje and Leerdam bastions was the residence of the Dutch commander at the Cape.

Die Kasteel voor die bou van die Kat of afskortingsmuur in 1695. Halfpad tussen die Katzenellenbogen en Buren bastions het die hek vanaf die waterkant die hoofingang tot die Kasteel geword tot die Simon van der Stel ingang in April 1684

voltooi is. Ontoeganklikheid met hoogwater, verdedigingsprobleme en die sanderige toegang wat onbegaanbaar was vir gelaaide waens, was van die oorwegings wat hierdie verandering genoodsaak het. Die vrees het bestaan dat die ravelyn voor die waterhek vir die wyand meer sou beteken as vir die verdedigers van die Kasteel. In die middel is die put. Tussen die Oranje en Leerdam bastions het die Hollandse kommandeur aan die Kaap tuisgegaan. 
Map of the old Table Bay Kaart van ou Tafelbaai

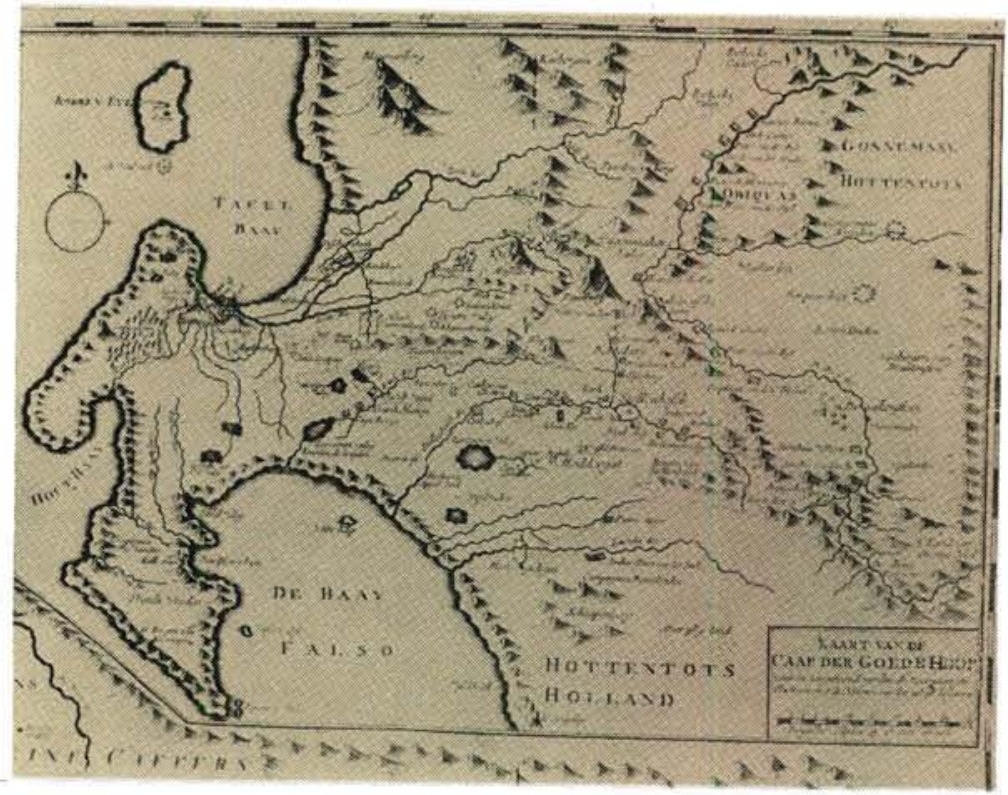

Commissioner Isbrand Goske who selected the site on which the Castle was later built in August 1665. Goske was Governor of the Cape from 1672-1676 and played a decisive role in completing the Castle.

Kommissaris Isbrand Goske wat die perseel gekies het waarop die Kasteel later gebou is in Augustus 1665. Goske was Goewerneur aan die Kaap van 1672-1676 en het' $n$ beslissende rol gespeel in die voltooiing van die Kasteel.

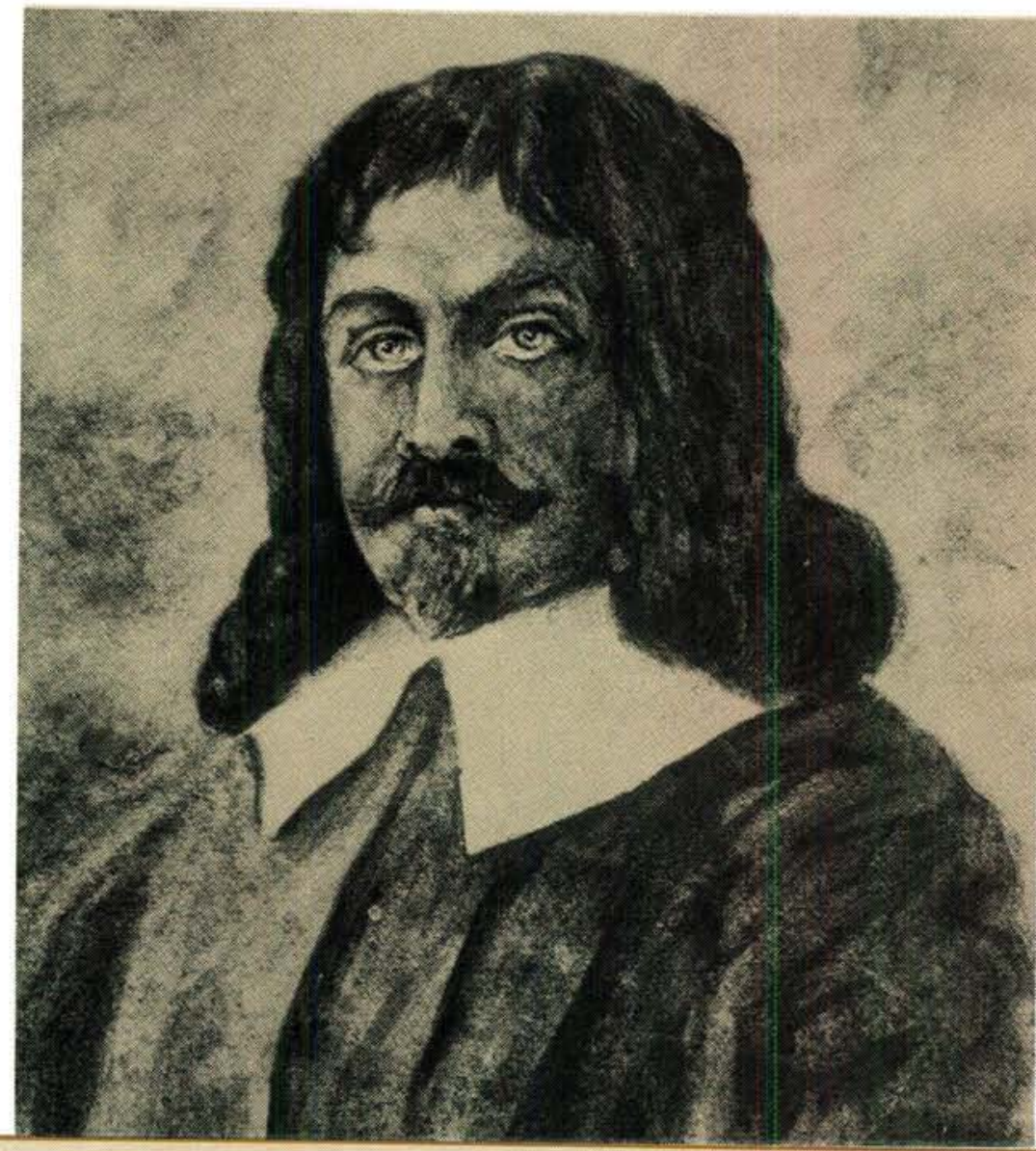


Drawing by Lady Anne Barnard with the Castle in the foreground. Notice the statues by Anreith above the gateway (circa 1797).

Tekening deur Lady Anne Barnard van Tafelbaai met die Kasteel in die voorgrond. Let op die standbeelde van Anton Anreith op die hekpilare (circa 1797).

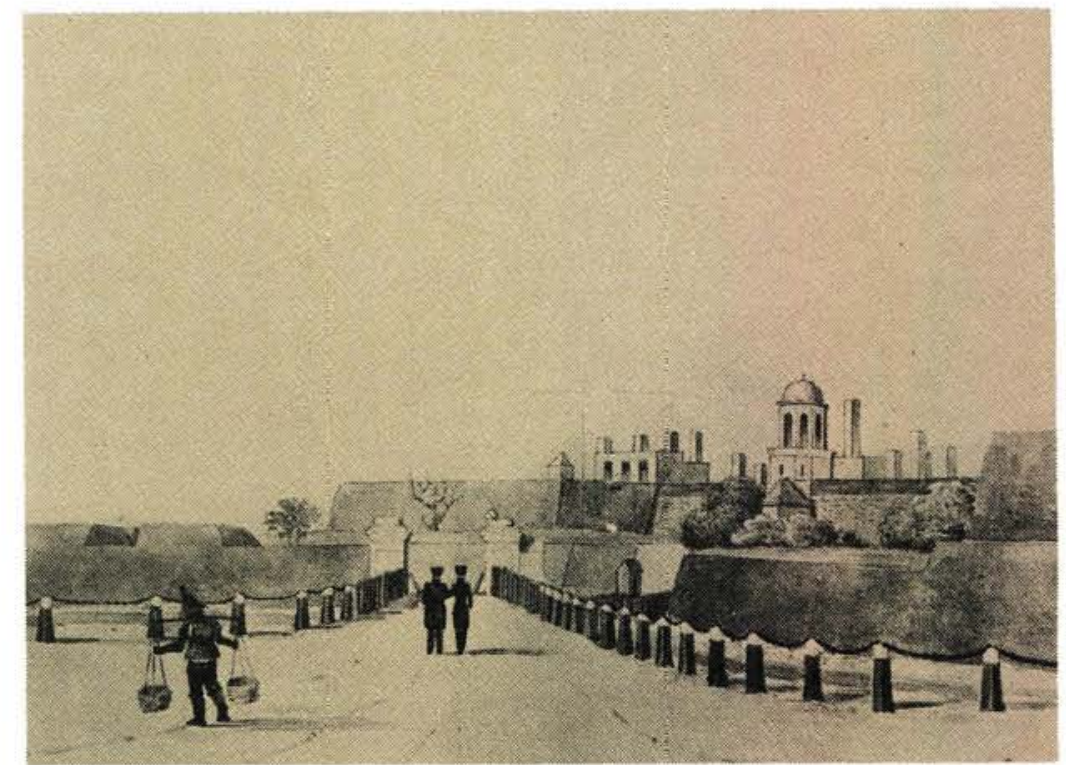

The outer square from the roof of Government House in the Castle circa 1796 as seen by Lady Anne Barnard, wife of Mr Andrew Barnard the Colonial Secretary of the Cape Colony. Lady Anne Barnard was the daughter of the Earl of Balcarres.

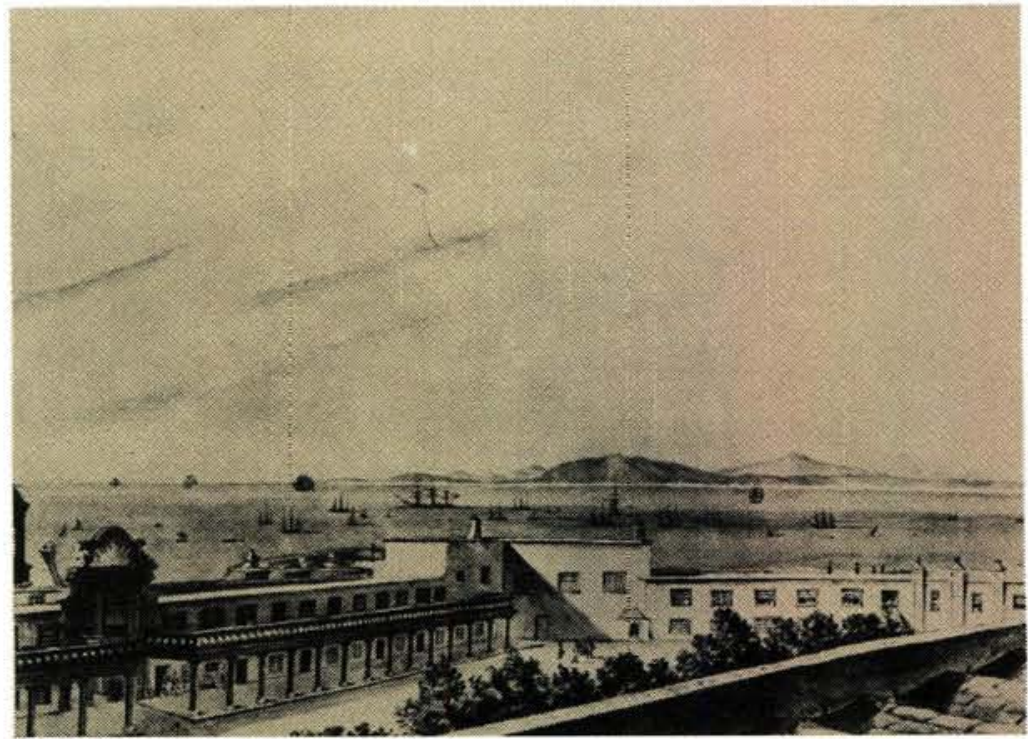

Die buitenste vierkant van die Kasteel (omstreeks 1796) soos gesien deur Lady Anne Barnard, vrou van mnr Andrew Barnard, die Koloniale Sekretaris van die Kaap Kolonie. Lady Anne Barnard was die dogter van die Graaf van Balcarres. 


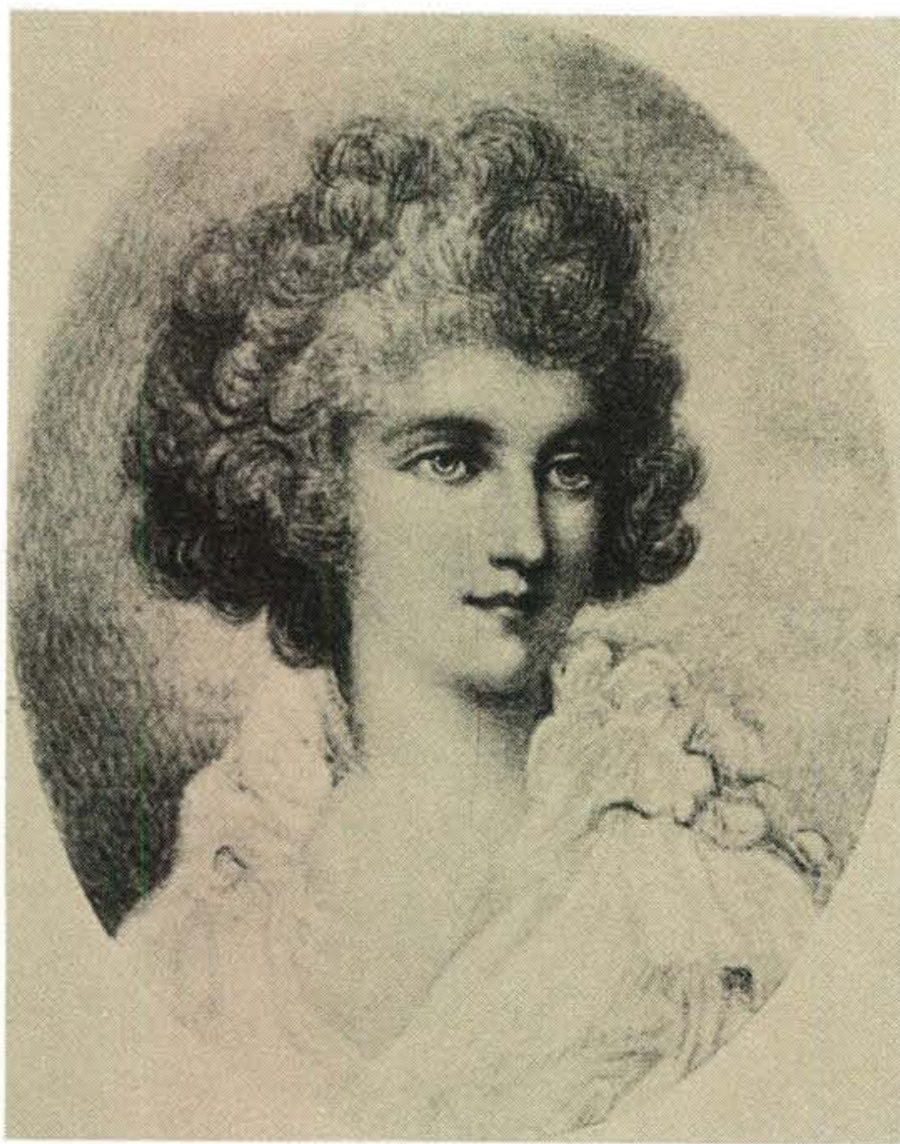

Lady Anne Barnard whose letters and paintings give a fascinating picture of the Castle during the first British Occupation of the Cape 1795-1803.

Lady Anne Barnard. Haar briewe en skilderye bied ' $n$ fassinerende blik op die Kasteel gedurende die eerste Britse Besetting van die Kaap in $1795-1803$.

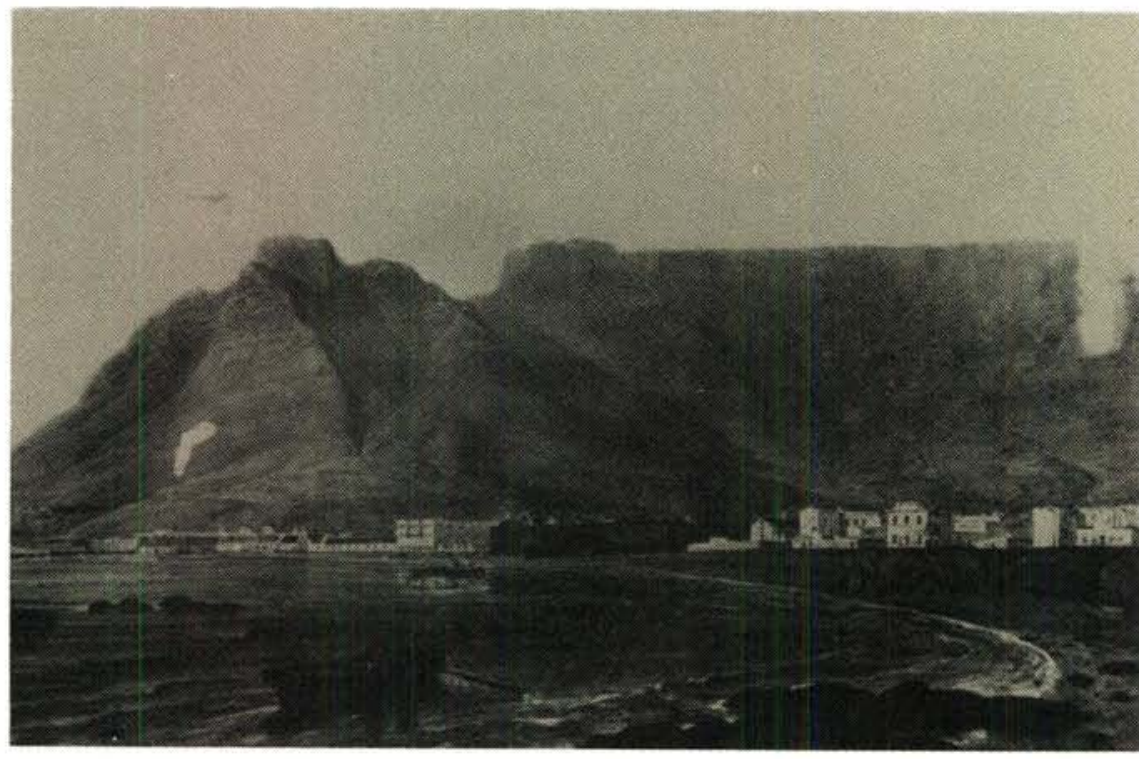

A drawing of Table Bay by Lady Anne Barnard with the Castle in the foreground.

'n Tekening deur Lady Anne Barnard van Tafelbaai met die kasteel in die voorgrond. 
The Dolphin fountain which stood in the middle of the pool of the Governor's garden in the Inner courtyard. The statue was not found when the pool was excavated in 1983.

Die Dolfyn spuitfontein wat in die middel van die wwer binnehof van die Goewerneurstuin geleë was. Die standbeeld is nie gevind toe die wwer opgegrawe is nie.
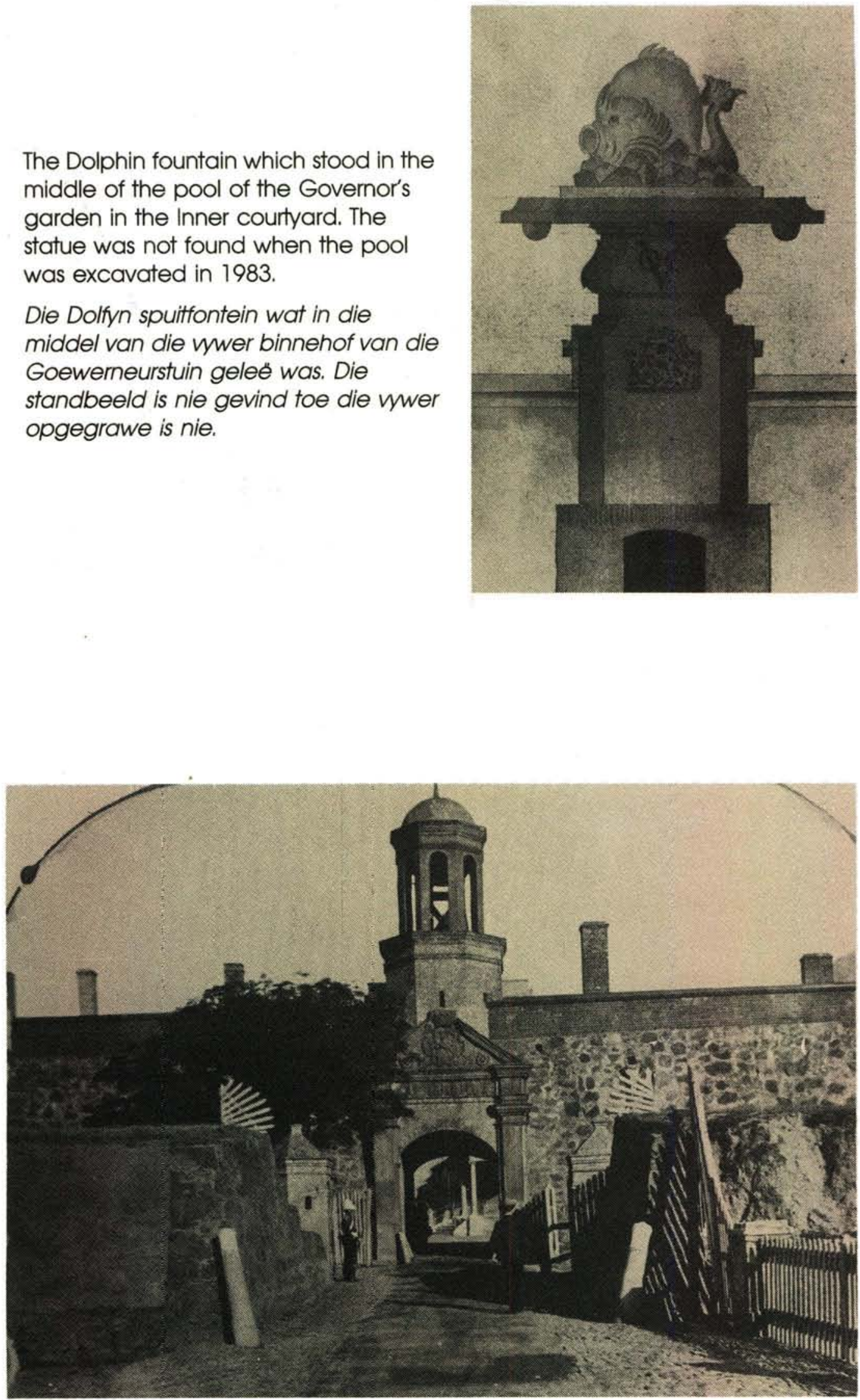

The Van der Stel gateway during the latter half of the 19th Century.

Die Van der Stel poort gedurende die tweede helfte van die 19de eeu. 


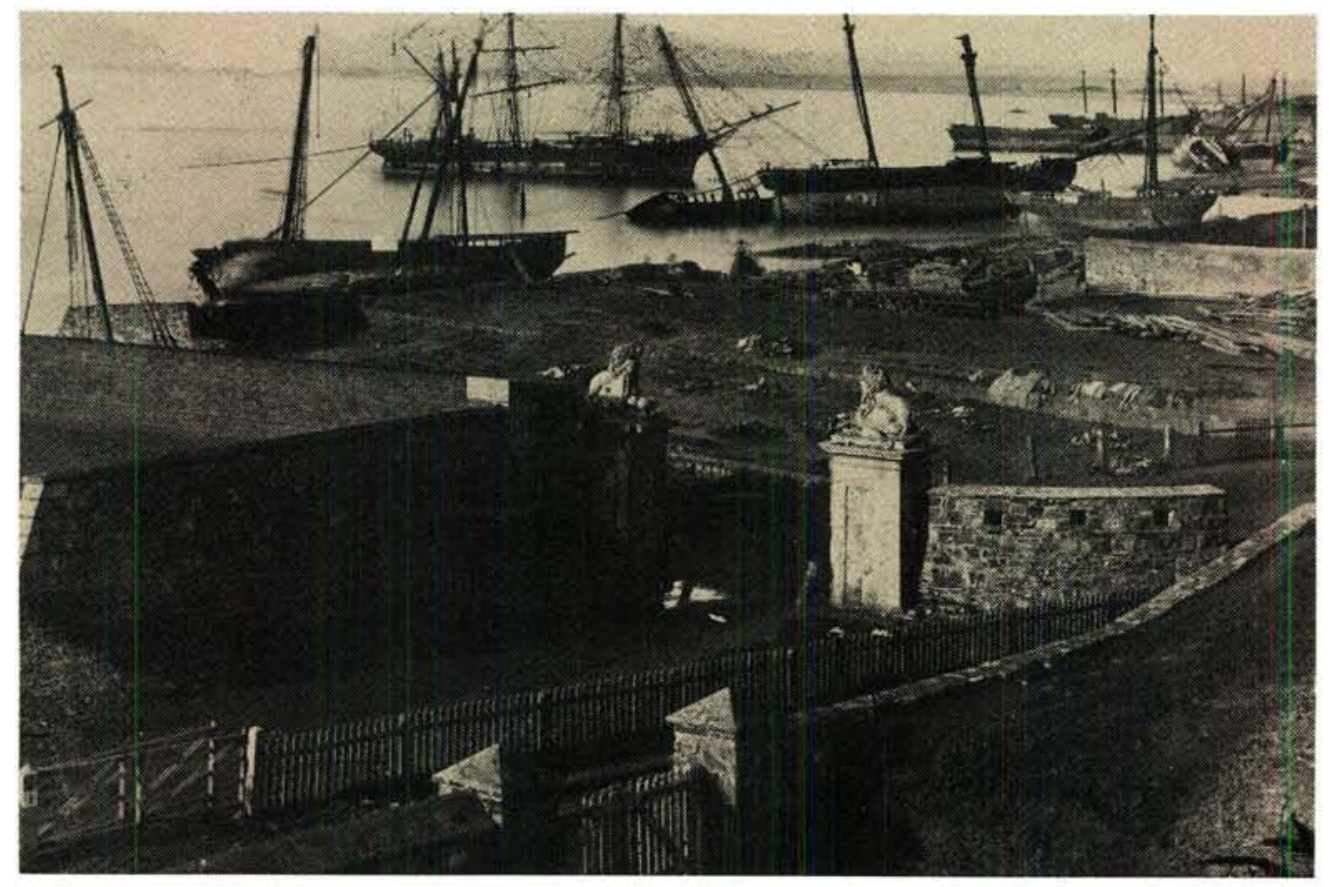

On 17th May 1865 one steamer and some 36 other ships were wrecked in the Great Gale in Table Bay. To the left of the wooden fence was the Imhoff Battery which was situated on the seaward side of the Castle.

Op $17 \mathrm{Mei} 1865$ het 'n stoomskip en sowat 36 ander skepe gestrand tydens die Groot Stormwind in Tafelbaai. Links van die hout heining was die Imhoff Battery wat aan die seekant van die Kasteel geleë was.

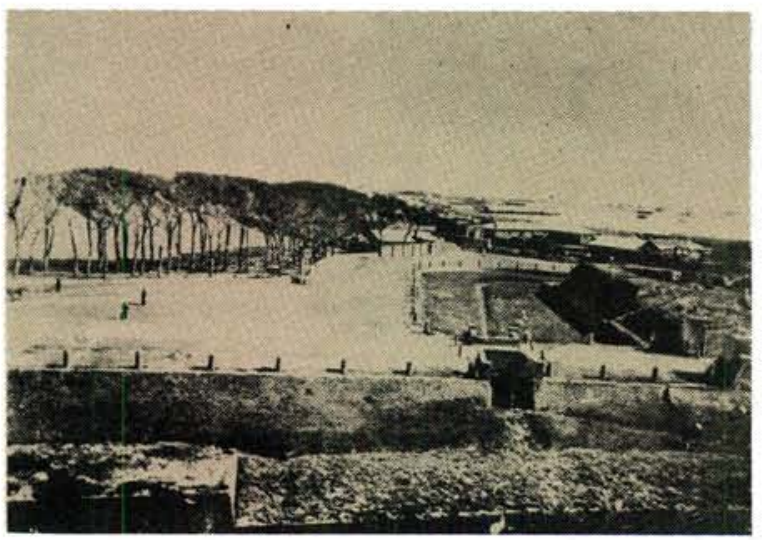

The Grand Parade and lioness gateway to the Castle. The lionesses are attributed to the sculptor Anton Anreith. During the 19th century the smell of the muddy moat known as the Castle Ditch was often the subject of unfavourable comment.

Die Parade en die Leeuin ingang na die Kasteel. Die standbeelde van die Leeumyfies word aan die beeldhouer Anton Anreith toegeskryt. Gedurende die 19 de eeu was die reuk van die modderige meer, beter bekend as die Kasteel Dyk, dikwels die onderwerp van ongunstige kommentaar. 


\section{The Castle of Good Hope}

Miss W.J. Kroukamp

\section{Die Kasteel de Goede Hoop}

Within the sturdy stone walls of the Castle, the early history of our country was wrought by a handful of people, who over the centuries developed into a prosperous community.

The arrival of three ships in Table Bay Harbour in April 1652 was the beginning of a new epoch in the history of South Africa. They had hardly cast anchor, when Commander Jan van Riebeeck went ashore to select a suitable site for the erection of a fort.

A wild and untamed landscape stretched out in front of them. From the ravines the roar of lions could be heard and hippopotami paddled about undisturbedly in the marsh. They also made the acquaintance of the south-east wind (south-easter) which would in years to come considerably delay work on the fort.

Jan van Riebeeck's main function, as embodiment of the authority of the Netherlands East India Company in the southern corner of Africa, was primarily of a military nature. The fort had to serve as a military stronghold in order to confirm and maintain the Netherlands' claim to Table Bay.

Work on the fort had to commence immediately. On a piece of land near the beach on the eastern side of a fresh water river, the first foundations were dug. The fort would take on the shape of a rectangular square fortress with four bulwarks or bastions.

On May 15th the name "De Goede Hoop" was bestowed on the fort. The four points or bastions were named after the four ships that lay in the bay: Drommedaris, Walvisch, Oliphant and Reijger. Although numerous problems such as illness and shortage of building materials recurred, the fort was in a reasonably advanced stage of completion after a month of untiring hard labour.
Binne die stewige klipmure van die Kasteel is die vroee geskiedenis van ons land gesmee deur 'n handjievol mense wat oor die eeve heen gegroei het tot ' $n$ welvarende samelewing.

Die verskyning van drie skepe in Tafelbaai se hawe in April 1652 was die begin van 'n nuwe tydvak in die Suid-Afrikaanse geskiedenis. Hulle het skaars anker gegooi toe Kommandeur Jan van Riebeeck aan land gegaan het om 'n geskikte terrein uit te soek vir die bou van 'n fort.

'n Woeste en ongerepte landskap het voor hulle uitgestrek. Vanuit die klowe is die gebrul van leeus gehoor en seekoeie het onverstoord in 'n moeras rondgeplas. Hulle het ook kennis gemaak met die suidoostewind wat in die daaropvolgende jare werk aan die fort aansienlik sou vertraag.

Jan van Riebeeck se vernaamste funksie as draer van die Nederlandse Oos-Indiese Kompanjiegesag na die Suidhoek van Afrika was grotendeels militêr van aard. Die fort moes as militêre vesting dien om Nederland se aanspraak op Tafelbaai te bevestig en te handhaaf.

Werk aan die fort moes onmiddellik begin. Op 'n stuk grond naby die strand aan die oostekant van 'n varswaterrivier is die eerste fondamente gegrawe. Die fort sou die vorm van 'n reghoekige, vierkantige vesting met vier bolwerke of bastions aanneem.

Op 15 Mei is die naam "De Goede Hoop" aan die fort gegee. Die vier punte of bolwerke is vernoem na die vier skepe wat in die baai gelê het: Drommedaris, Walvisch, Oliphant en Reijger. Hoewel talle probleme soos siektes en 'n tekort aan boumateriaal telkens opgeduik het, was die fort na 'n 
The probation period, however, only started after this point in time. With the arrival of the rainy season, insurmountable problems started to arise. A terrible time followed. The people still remained more or less unsheltered and temporary wooden sheds could not keep out the rain. The constant exposure to dampness and the continuous labour caused illness to increase.

The first family moved into the fort on June 4th and on completion of the northern point, Reijger in August, everybody went to live in the fort. The lions' roar sounded less terrifying than before.

Jan van Riebeeck started his second year at the Cape with ample courage and new zeal. More than 170 men were working on the fort and the work progressed rapidly. The temporary wooden houses in the courtyard were replaced by stone houses. The last two bastions, Walvisch and Oliphant were completed in May and June 1953.

Notwithstanding the problems that they experienced, van Riebeeck announced that their fort was entirely defensible, eighteen months after the first foundations were dug.

During the next rainy season it became evident that the mud walls of the fort were not proof against the soaking rains. It was so dilapidated that parts of it had to be rebuilt from the foundations. Branches and shrubs were mixed with the sods in the hope that it would lend more stability. The fort itself was completed towards the end of 1653.

In March 1656 the work on the fort, including the interior buildings, was completed. With the object of more efficient defence, the "Cat" which was already 7 feet higher than the walls of the fort, was built still higher. Continuous collapse and rebuilding of walls had already become routine work. Even Jan van Riebeeck had to admit that the fort was crumbling.

After ten long years of pioneering, Jan van Riebeeck departed from the Cape. His final request from his successor Zacharias Wage- maand van onvermoeide en harde arbeid al in 'n redelike gevorderde toestand.

Die proeftydperk het egter eers ná hierdie tyd aangebreek. Met die koms van die reënseisoen het onoorkomlike probleme begin kop uitsteek. 'n Ellendige tyd het gevolg. Die mense was nog grotendeels onbeskut en die tydelike houtafdakke kon nie die reën uithou nie. Die gedurige blootstelling aan klammigheid en aanhoudende werk het die siektes laat toeneem.

Die eerste gesin trek op 4 Junie in die fort in en met die voltooiing van die noordpunt, Reijger, in Augustus, het almal in die fort gaan woon. Die gebrul van leeus het minder skrikwekkend geklink as voorheen.

Jan van Riebeeck begin sy tweede jaar aan die Kaap vol moed en nuwe ywer. Meer as 170 mans werk aan die fort en werk vorder vinnig. Die tydelike houthuise op die binneplein word vervang met kliphuise. Die laaste twee bolwerke, Walvisch en Oliphant word in Mei en Junie 1653 voltooi.

Afgesien van die probleme wat hulle ondervind het, berig van Riebeeck 18 maande na die eerste fondamente gegrawe is, "ons fort is in volcomen deffentie".

Gedurende die volgende reënseisoen het dit duidelik geword. dat die fort se kleimure nie bestand was teen die deurdringende reëns nie. Dit was só bouvallig dat dele daarvan uit die fondamente herbou moes word. Takke en bosse is tussen die sooie ingewerk met die hoop dat dit meer stewigheid sou verleen. Die fort self was teen einde 1653 voltooi.

In Maart 1656 was die werk aan die fort, insluitende die binnegeboue, afgehandel. Met die oog op doeltreffender verdediging is die "kat", wat reeds 7 voet hoër was as die mure van die Fort, nog hoër opgemessel. Voortdurende ineenstortings en heropbou van mure het reeds roetinewerk geword. Selfs Jan van Riebeeck moes toegee dat die fort besig was om te verbrokkel. 
naar was that a large firm stone fort should be erected for the protection of the colonists.

The winter rains of 1663 , accompanied by the crumbling of the fort, was the last straw for Zacharias Wagenaar. He made an urgent appeal to the "Here XVII" to replace the mud fort with one of stone. In April 1665 Wagenaar received instructions to carry on with the erection of a stone castle.

The laying of the corner stone of the Castle of Good Hope on the terrain "66 Rhijnlandse Roeden", east of the old fort, was celebrated in a festive manner in January 1666. The new fort would take on the shape of a pentagon, in other words a fortress with five bastions. Underneath each bastion would be a powder magazine. Around the castle a moat of 2,5 metres would be dug. The engineer Pieter Dombaer was commissioned to erect the building.

The work was tackled with new zeal. A large "boerhuys" was immediately erected in the centre of the courtyard, providing shelter against the rain and gale winds.

The building operations progressed rapidly. Even the soldiers were used to break stones and to gather shells for the lime. The foundations of the first bastion were nearly completed by May 1666. It was accordingly estimated that it would take ten to twelve years' hard work to complete the Castle; that is five bastions, moats, bridges, sea dikes, basements, sewerage, draw-wells, warehouses and living quarters.

News reached the Cape in July 1672 that war had broken out between the Netherlands and France. Preparations for the defence of the Cape were made and work on the Castle was continued in all haste. A new Governor, Isbrand Goske, arrived at the Cape and immediately inspected the building site. The progress was, however, not as successful as was hoped. The old problem of rain, illness and lack of workers once more arose. In addition the Company wanted to keep the building expenses as low as possible, but their efforts to economise, on the contrary, cost them rather more than less.
Na tien lange jare van baanbrekerswerk vertrek Jan van Riebeeck uit die Kaap. Sy laaste versoek aan sy opvolger, Zacharias Wagenaar, was om 'n groot en stewige klipfort ter beskerming van die nedersetters op te rig.

Die winterreëns van 1663 met die gepaardgaande verbrokkeling van die fort was die laaste strooi vir Zacharias Wagenaar. Hy doen 'n dringende beroep op die Here XVII om die kleifort met klip te vervang. In April 1665 ontvang Wagenaar opdrag om voort te gaan met die bou van 'n klipkasteel.

Die hoeksteenlegging van die Kasteel de Goede Hoop op die nuwe terrein "60 Rhijnlandse Roeden" oos van die ou fort, is in Januarie 1666 op 'n feestelike wyse gevier. Die nuwe fort sou die vorm van 'n pentagoon aanneem, dws 'n vesting met wy bolwerke. Onder elke bolwerk sou 'n kruitmagasyn wees. Rondom die kasteel sou 'n grag van 2,5 meter gegrawe word. Die bouwerk is opgedra aan die ingenieur, Pieter Dombaer.

Die werk is met hernude ywer aangepak. 'n Groot "boerehuys" is onmiddellik in die middel van die binneplein opgerig wat vir die werkvolk as skuiling sou dien teen die reën en stormwinde.

Bouwerk het vinnig gevorder. Selfs die soldate is ingespan om klippe te breek en skulpe vir kalk bymekaar te maak. Die fondamente van die eerste bolwerk was in Mei 1666 byna voltooi. Daarvolgens is bereken dat dit tien tot twaalf jaar se harde werk sou kos om die hele Kasteel, dws wy bolwerke, gragte, brûe, seedyke, kelders, riole, waterpulte, pak- en woonhuise, te voltooi.

Nuus bereik die Kaap in Julie 1672 dat oorlog tussen Nederland en Frankryk uitgebreek het. Voorbereidings ter verdediging van die Kaap is getref en werk aan die Kasteel is in aller haas voortgesit. 'n Nuwe goewerneur, Isbrand Goske, arriveer in die Kaap en inspekteer die bouterrein onmiddellik ná sy aankoms.

Die vordering was egter nie so voorspoedig as wat gehoop is nie. Die ou probleme van 
Despite all the setbacks, the fortress approached completion, slowly but surely. In October 1673 the "corps de guarde" in the sea point was completed. Two months later the third bastion was ready and shortly thereafter the fourth bastion was brought to the required height.

Isbrand Goske at this stage felt that his task at the Cape had been completed. In March 1676 Johan Bax was appointed the new governor at the Cape. At the same time the fifth bastion was completed. The most urgent work that still lay ahead was the completion of the gateway, the interior heights of the curtains and the warehouses.

The powder cellar that was commenced during Isbrand Goske's time was completed in March 1677. Before the Castle of Good Hope could be regarded as completed, accommodation had to be built for the sickcomforter, preacher and the governor, and a moat had to be dug. Quite a number of defence constructions also had to be added before it would comply with the requirements of a military stronghold.

Governor Bax received a serious warning from the authorities to be on the lookout for an enemy attack. The garrison would have to be enlarged without delay. Two years after his entering office, governor Bax could proudly announce to the "Here XVII" that the Castle was for the first time in a "tamelijke genoegsame postuur van deffentie".

On the death of governor Bax, the following interior buildings had already been completed: powder cellars, a provision warehouse, a ships doctors' shop, warehouses and living quarters and a carpenter's shop.

In April 1679 the Political Council decided to name the five bastions of the Castle in honour of Prince Willem of Oranje (William of Orange) as follows:

West Bastion:

Leerdam

South Bastion:

Southeast Bastion:

Oranje

East Bastion:

North Bastion: reën, siektes en gebrek aan werkvolk het weer eens opgeduik. Boonop wou die Kompanjie die boukoste so laag as moontlik hou, maar hul poging om te besuinig het hulle eerder duurder te staan gekom.

Ten spyte van al die teenslae, nader die vesting stadig maar seker voltooiing. In Oktober 1673 was die "corps de guarde" in die seepunt voltool. Twee maande later was die derde bolwerk gereed en kort daarna is die vierde bolu ark tot op die vereiste hoogte gebring.

Isbrand Goske het in dié stadium gevoel dat sy taak aan die Kaap afgehandel was. In Maart 1676 word Johan Bax as nuwe goewerneur aan die Kaap aangestel. Terselfdertyd word die wyde bolwerk voltooi. Die dringendste werk wat nog voorgelê het, was die voltooiing van die poort, die binneste hoogtes van die gordyne en die pakhuise.

Die kruitkelder wat gedurende Isbrand Goske se tyd begin is, word in Maart 1677 voltooi. Voordat die Kasteel de Goede Hoop as voltooi beskou kon word, moes verblyf vir die sieketrooster, predikant en goewerneur opgerig en die grag gegrawe word. 'n Hele aantal verdedigingskonstruksies moes ook bygevoeg word voordat dit aan die doel van 'n militêre vesting beantwoord het.

Goewerneur Bax ontvang van owerheidsweë 'n ernstige waarskuwing om op sy hoede te wees teen 'n wandelike aanval. Die garnisoen sou sonder versuim vermeerder moet word. Twee jaar ná sy diensaanvaarding, kon Goewerneur Bax met trots aan die Here XVII berig dat die Kasteel vir die eerste keer in "tamelijcke genoegsame postuur van deffentie" was.

Met die afsterwe van Goewerneur Bax was die volgende binnegeboue reeds voltool: Kruitkelders, 'n negosiepak'huis, 'n sjirurgynswinkel, pak- en woonhuise en 'n timmermanswinkel.

In April 1679 besluit die Politieke Raad om die wy punte of bolwerke van die Kasteel ter ere van prins Willem van Oranje soos volg te noem: 
With the arrival of Simon van der Stel at the Cape in 1679, most of the work on the Castle had been completed.

He made changes and additions to the Castle, on his own initiative. The approach from the sea was closed and the main entrance, as we know it today, was built. The pentagonal courtyard was divided by a wall curtain, known as the "Cat" and the balcony was added which would become the centre of activities in the Castle. The Bell Tower above the entrance was built and the original bell which was cast in Amsterdam in 1699 , still hangs in it.

The termination of the Netherlands occupation of the Cape in the 18th century, brought about great change at the Castle. Holland and England were in a state of war against France, and England sent an expeditionary force to seize the Cape in order to prevent it from coming into French possession. British soldiers marched into the Castle in 1795.

In 1797 the first British governor, Lord McCartney arrived at the Cape. He was accompanied by his secretary Andrew Barnard whose wife Lady Anne brought gaiety and colour to the Castle.

For almost half a century the Castle remained the centre of the economical and social life of the Europeans in South Africa. Nevertheless the continued existence of this oldest and most important building in South Africa, was threatened on three occasions during the 19th century. In 1864 governor Philip Wodehouse recommended that it should be done away with, as a means of economising. The plan was, however, postponed and later abandoned.

In 1866 the military authority decided to demolish the Castle. According to the British officers the building was not hygienic enough and it was inadequate as a military stronghold. They wanted to erect barracks in its place. Protest campaigns were held and the "Afrikanerbond" under the leadership of Jan Hofmeyer directed powerful appeals to
Wespunt:

Leerdam

Suidpunt:

Oranje

Suidoostelike punt:

Oospunt:

Noordpunt:

Nassau

Katzenellenbogen

Buren

Met Simon van der Stel se koms in 1679 aan die Kaap is meeste van die bouwerk aan die Kasteel voltooi. Hy bring op eie inisiatief veranderinge en byvoegings aan die Kasteel aan. Die toegang van die see af word toegemaak en die hoofingang, soos ons dit vandag ken, word gebou. Die wythoekige binnewerf word verdeel deur 'n muurgordyn, bekend as die "Kat" en 'n balkon word bygevoeg wat die middelpunt van die bedrywighede in die Kasteel sou word. Die kloktoring bo die ingang is gebou en die oorspronklike klok wat in 1699 in Amsterdam gegiet is, hang steeds daarin.

Die beëindiging van die Nederlandse besetting van die Kaap in die 18de eeu, bring groot veranderinge in die Kasteel teweeg. Holland en Engeland verkeer in 'n staat van oorlog teen Frankryk en Engeland stuur 'n ekspedisiemag om die Kaap te beset sodat dit nie in Franse besit kan kom nie. Britse soldate marsjeer in 1795 die Kasteel binne.

In 1797 arriveer die eerste Britse goewerneur, Lord Macartney, aan die Kaap. Hy word vergesel deur sy sekretaris, Andrew Barnard, wie se vrou, lady Anne, vrolikheid en kleur aan die lewe in die ou Kasteel bring.

Vir byna 'n halfeeu was die Kasteel die middelpunt van die ekonomiese en maatskaplike lewe van die Blanke in Suid-Afrika. Tog was die voortbestaan van hierdie oudste en belangrikste gebou in Suid-Afrika in die 19de eeu drie keer bedreig. In 1864 het goewerneur Philip Wodehouse aanbeveel dat as 'n besparingsmiddel daarmee weggedoen sal word. Die plan is egter uitgestel en later afgestel.

In 1866 besluit die militêre owerheid om die Kasteel af te breek. Volgens Britse offisiere was die gebou nie higiënies genoeg nie en was dit ondoeltreffend as 'n militêre vesting. Hulle wou barakke in sy plek oprig. Protes- 
the queen. Accordingly, the building was saved.

Towards the end of the 19th century the Railways insisted on the demolition of the Castle to make way for railway lines to the Cape station. They were successful in that the Van Immhoff Battery and the Van Immhoff house were removed, but public resistance against it, under the leadership of Mrs Marie Koopmans-De Wet, prevented the demolition of the Castle.

During the 19th century the state departments were gradually removed from the Castle so that only the army remained. In 1917 the Imperial Powers handed the Castle over to the SA Defence.

Today, thousands of rand are spent yearly on the maintenance of the Castle. The Architect Francis Macey (Sir Herbert Baker's partner) had already written in 1908: "Old walls have been removed and new partitions made, and chimney pieces and doors swept away, making it difficult in many places to identify the position or determine the use of some of the old rooms. Now stands the poor building in mute but eloquent reproach at the indifference to its fate of those who should hold it their dearest possession."

Architects have already for the past few years, worked on the bastions of the Castle to prevent that they become more damaged. In excavations made in the courtyard, interesting discoveries with regard to the history of the Castle were made. A swimming pool with a fountain was dug up as well as earthenware, pieces of porcelain and coins from the year 1797. The idea with the present restoration work is to assure that the Castle will remain standing for the next few centuries.

Today the Castle is not only a symbol of the administrative developments of the Cape of Good Hope, but also of the perseverance and drive displayed by South Africans from veldtogte is gehou en die Afrikanerbond onder leiding van Jan Hofmeyer het kragtige vertoe aan die Koningin gerig. Sodoende het die gebou behoue gebly.

Teen die einde van die 19de eeu het die spoonwee op die sloping van die Kasteel aangedring om plek te maak vir spoorlyne na die Kaapse stasie. Hulle was suksesvol in soverre die Van Immhoff-battery en daarmee die Van Immhoff-huis verwyder is, maar die openbare verset daarteen onder leiding van mev Marie Koopmans-De Wet, het die sloping afgeweer.

In die loop van die 19de eeu is die staatsdepartemente geleidelik van die Kasteel verskuif sodat net die leërmag oorgebly het. In 1917 het die Imperiale Magte die Kasteel aan die S.A. Weermag oorhandig.

Vandag word duisende rande jaarliks aan die onderhoud van die Kasteel bestee. Die argitek Francis Macey (Sir Herbert Baker se vennoot) het reeds in 1908 geskryt: "Old walls have been removed and new partitions made, and chimney pieces and doors swept away, making it difficult in many places to identify the position or determine the use of some of the old rooms. Now stands the poor building in mute but eloquent reproach at the indifference to its fate of those who should hold it their dearest possession."

Argitekte werk al die afgelope paar jare aan die bolwerke van die Kasteel om te voorkom dat dit verder beskadig word. In uitgrawings wat in die binnehof gemaak is, is interessante ontdekkings ivm die geskiedenis van die Kasteel gemaak. 'n Swembad met 'n spuitfontein is opgegrawe asook erdeware, porseleinstukke en muntstukke van 1797. Die idee van die huidige restorasiewerk is om te verseker dat die Kasteel vir die volgende paar eeve staande sal bly.

Vandag is die Kasteel nie slegs 'n simbool van die administratiewe en militêre ontwikkeling van die Kaap de Goede Hoop nie, maar ook van die volharding en deursettingsvermoë wat Suid-Afrikaners van geslag tot geslag openbaar het. Dit is dus ook 
generation to generation. It is therefore only fitting that the oldest building in South Africa is presently again used as military Headquarters of Western Province Command.

\section{Blbliography}

1. RAS, A.C. Die Kasteel en andere vroee Kaapse vestingswerke, 1652-1713, Tafelberg Publishers (Edms) Bpk, Kaapstad, 1959. paslik dat die oudste gebou in Suid-Afrika huidiglik weer gebruik word as militêre hoofkwartier van die Kommandernent Westelike Provinsie.

\section{BIbliografie}

1. RAS, A.C. Die Kasteel en andere vroee Kaapse vestingswerke, 1652-1713, Tafelberg Uitgewers (Edms) Bpk, Kaapstad, 1959. 


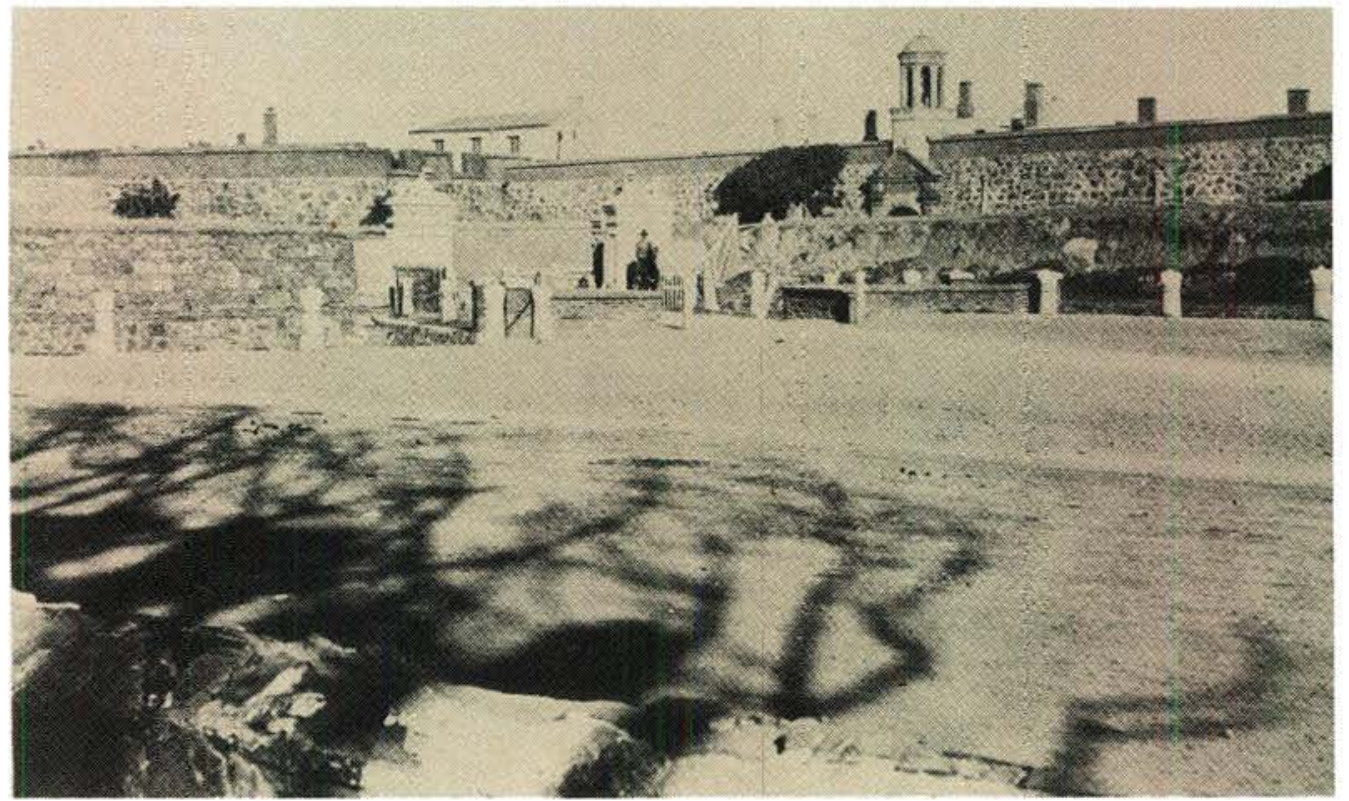

The main entrance to the Castle during the latter half of the 19th cenfury. The lower photograph was taken some years later.
4 Die hoofingang tot die Kasteel gedurende die laaste helfte van die 19 de eeu. Die onderste foto is etlike jare later geneem.

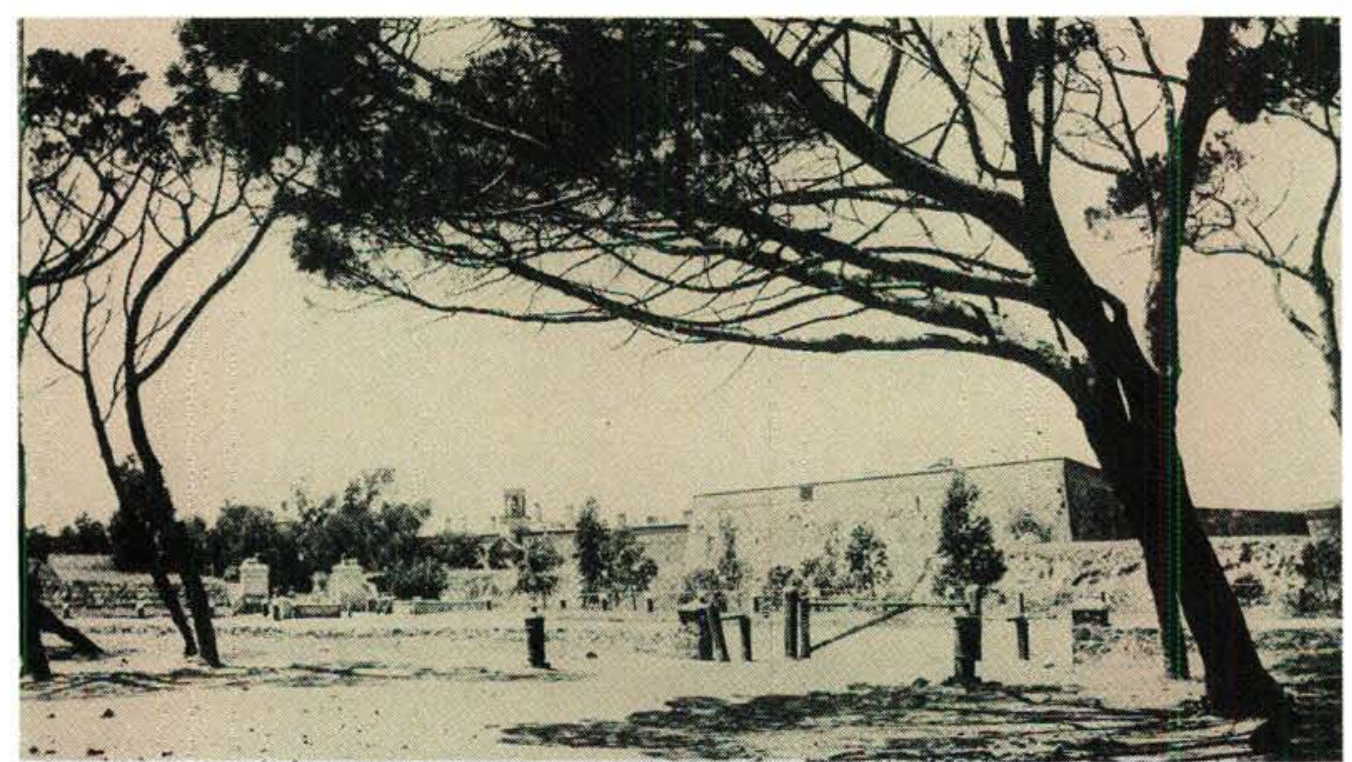




\section{The Castle in later years}

\section{Die Kasteel in later jare}

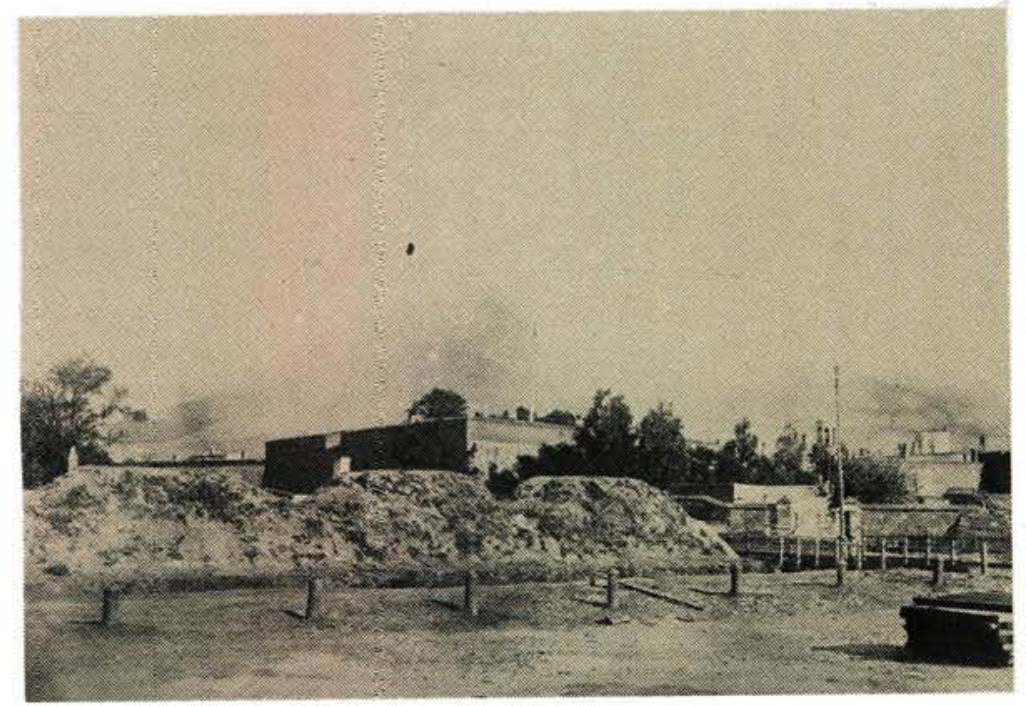

In 1879 Katzenellenbogen Bastion was known as Flagstaff Bastion. When this photograph was taken the flag had been moved to Buren Bastion.

In 1879 het Katzenellenbogen Bastion bekend gestaan as die Vlagstokbastion. Toe hierdie foto geneem is, was die vlag verskuif na Buren Bastion.

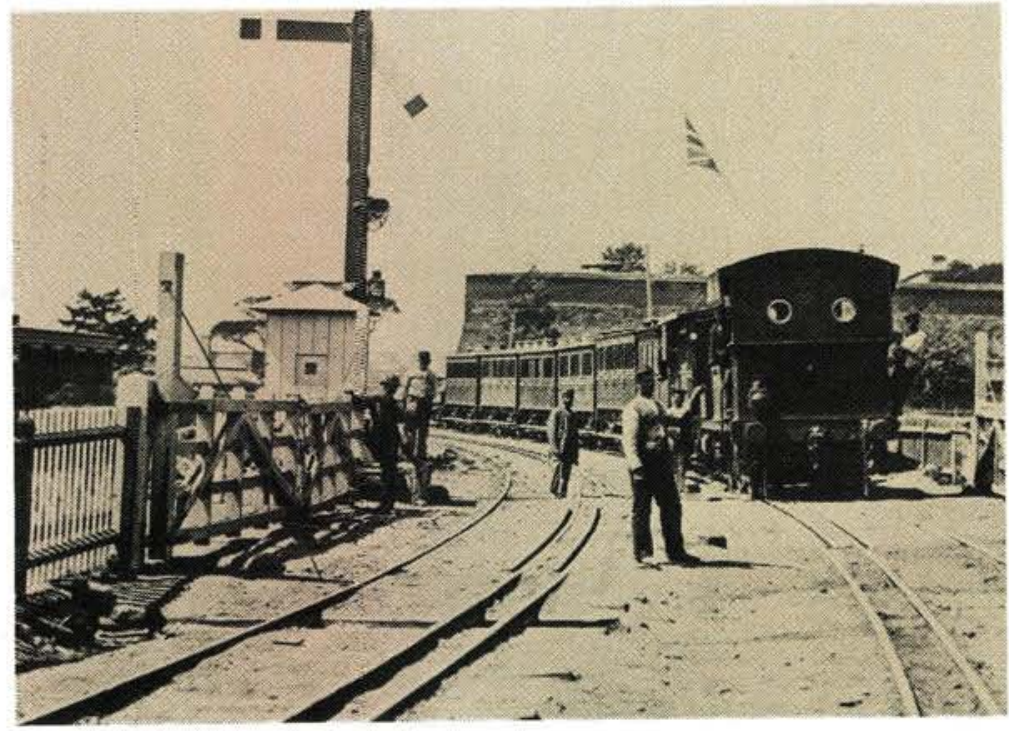

The greatest threats to the Castle have come not from an external enemy but from railway expansion on the seaward side, the tramways on the landward side of the building and the British Army, which attempted to sell and/or demolish the building in 1864, 1884 and 1886.

Die grootste bedreiging van die Kasteel het gekom, nie van 'n eksterne vyand nie, maar van die spoorweguitbreiding aan die seekant, die tremweë aan die landwaartse kant van die gebou en van die Britse Leër wat gepoog het om die gebou te verkoop en/of te sloop in 1864, 1884 en 1886. 
The Castle in 1925. The buildings in the Royal Engineers Yard between the Oranje and Leerdam Bastions can be clearly seen.

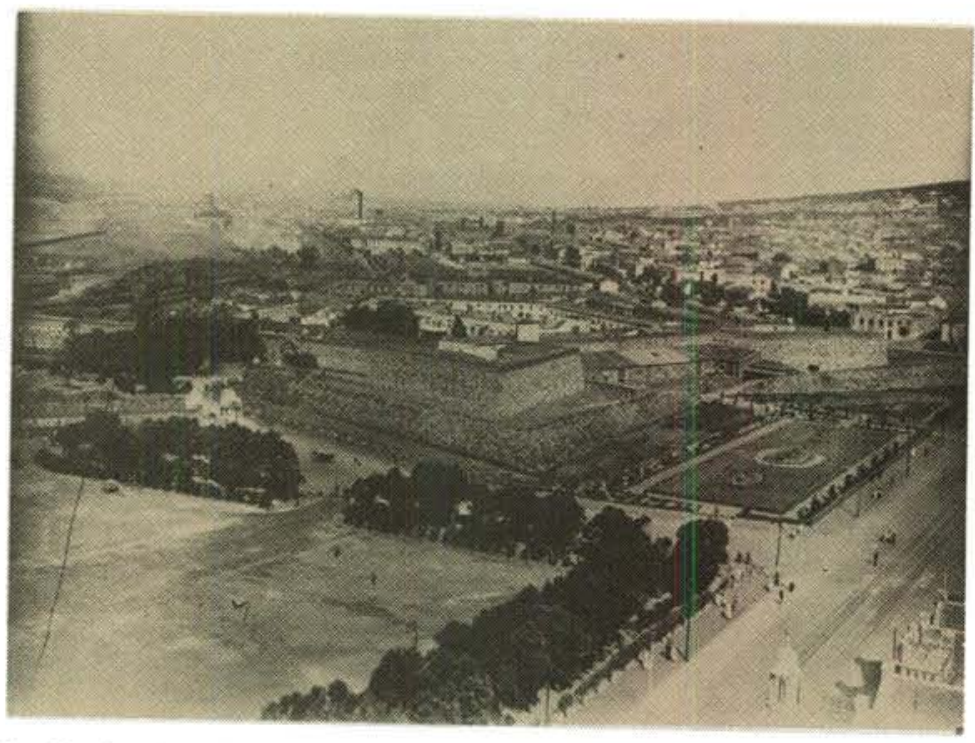

Die Kasteel in 1925. 'n Mens kan duidelik die gebou in die Koninklike Ingenieurswerf tussen die Oranje en Leerdam bolwerke sien.

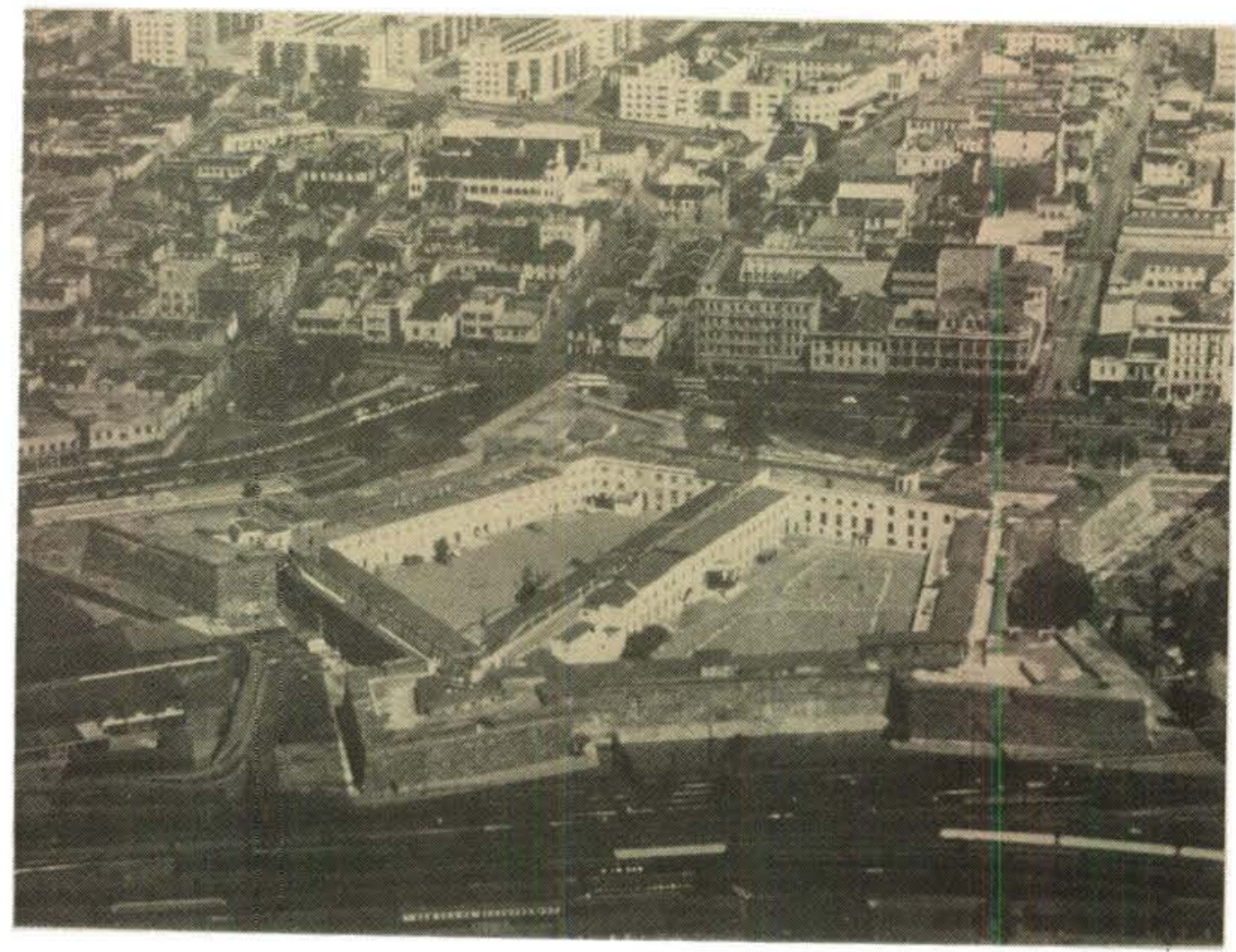

An aerial view of the Castle when the railroad was still there. Lugfọto van die Kasteel toe die treinspore nog daarlangs geloop het. 


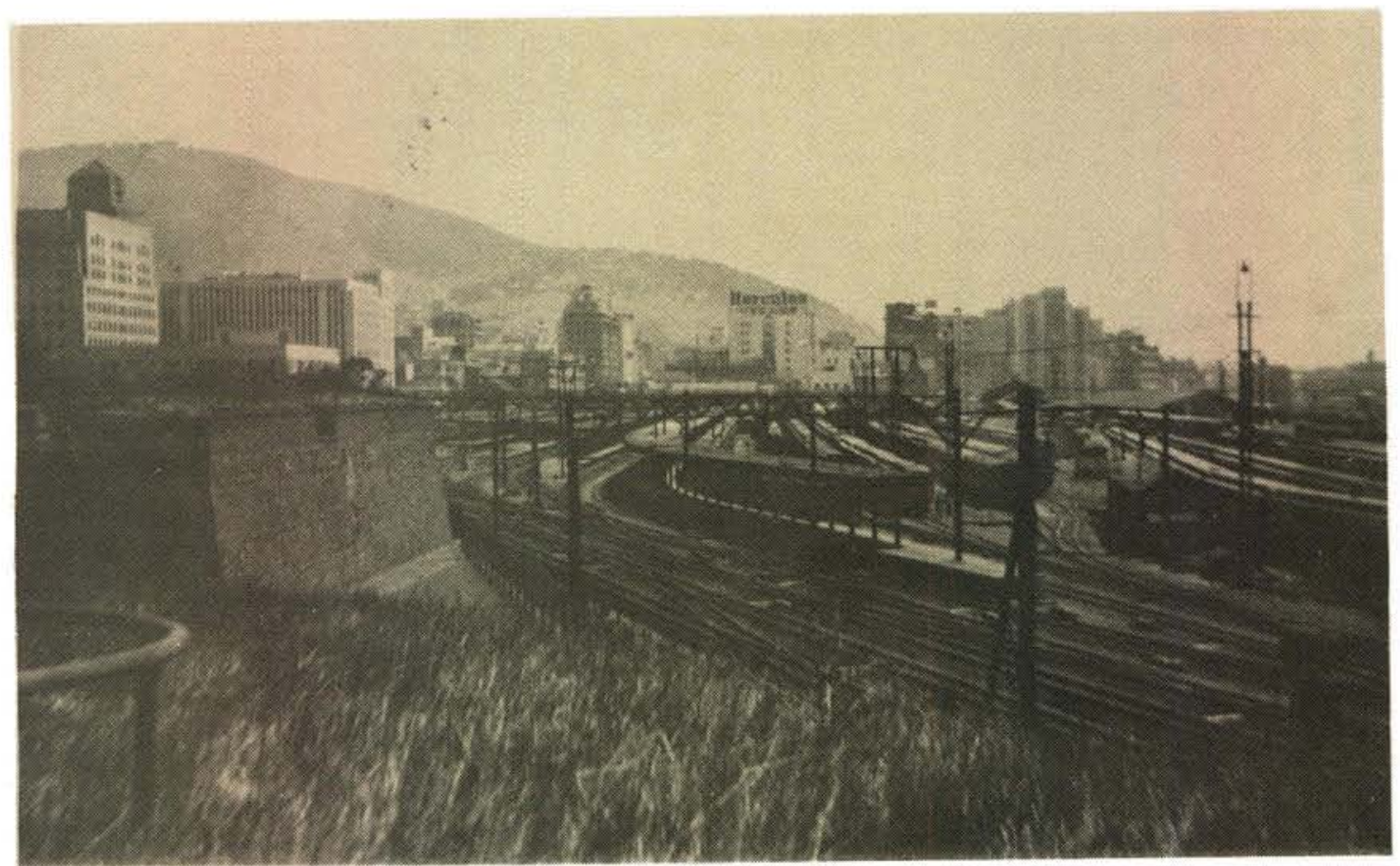

Buren Bastion and the railway line from Katzenellenbogen Bastion in April 1952. Buren Bastion en die spoorlyn vanaf Katzenellenbogen Bastion in April 1952.

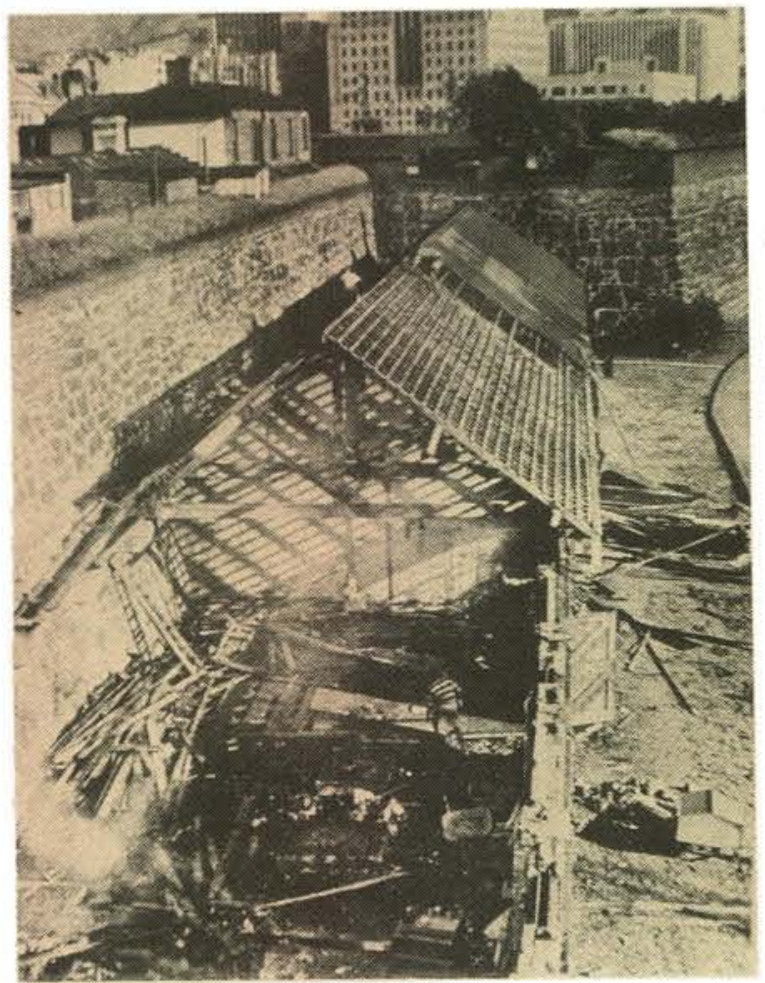

This photograph depicts the demolition of the wood and iron buildings between Katzenellenbogen and Buren on 2 August 1952.

Hierdie foto toon die sloping van die hout en yster gebou tussen Katzenellenbogen en Buren op 2 Augustus 1952 aan. 


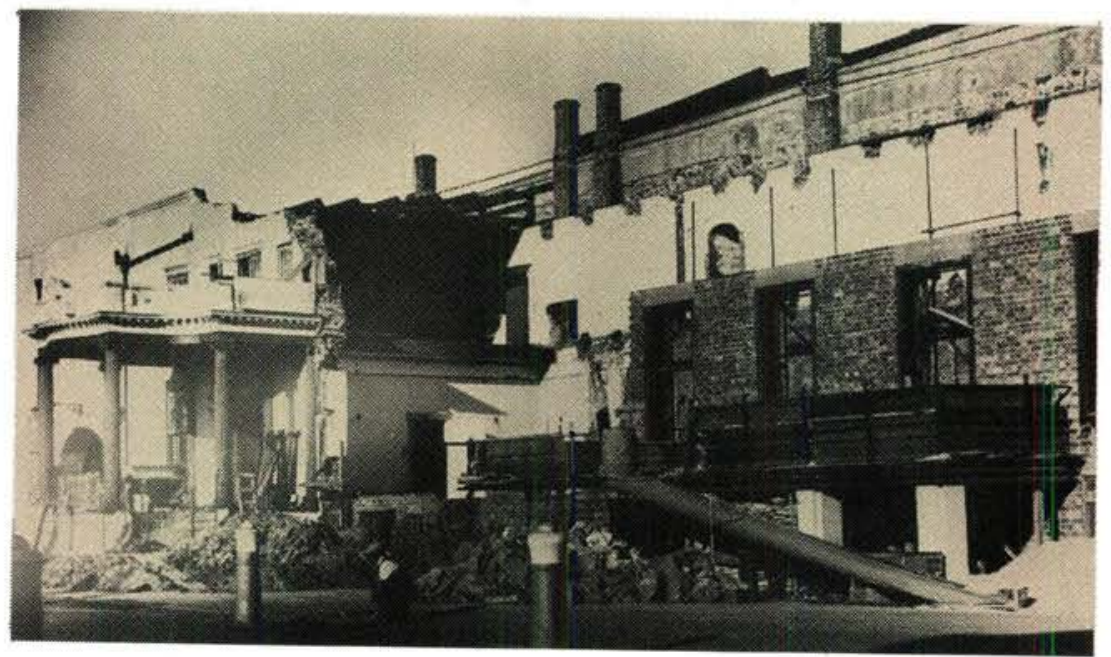

This remarkable photograph reveals the extent of the renovations carried out from 1935 to 1937. The fireplace, stairs and ballroom floor were replaced. The Castle was declared a national monument in 1936.

Dié merkwaardige foto toon die omvang van die restourasiewerk wat vanaf 1935 tot 1937 aan die Kasteel gedoen is. Die vuurherd, trap en die vloer van die balsaal is vervang. Die Kasteel is in 1936 as 'n nasionale monument verklaar.

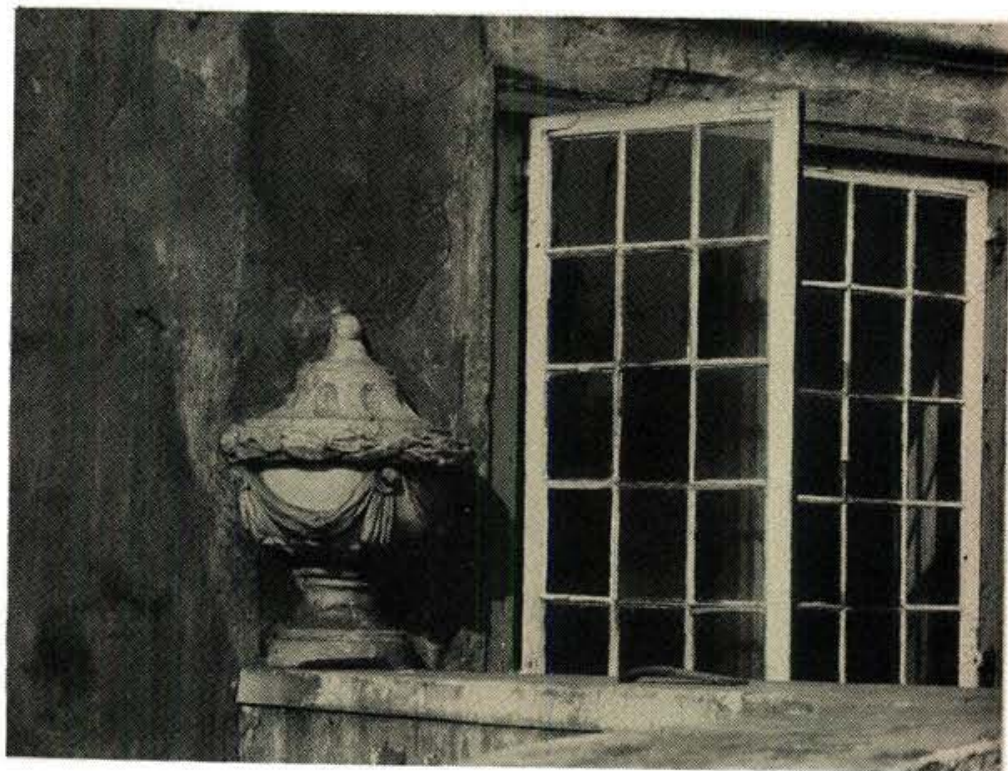

This decorative urn above the Nieuwe Kat balcony disappeared. It is most fortunate that this photograph of it has survived.

Dit is 'n geluk dat 'n foto van hierdie dekoratiewe kruik bo die "Nieuwe Kat" balkon behoue gebly het, want die kruik het daarna verdwyn. 


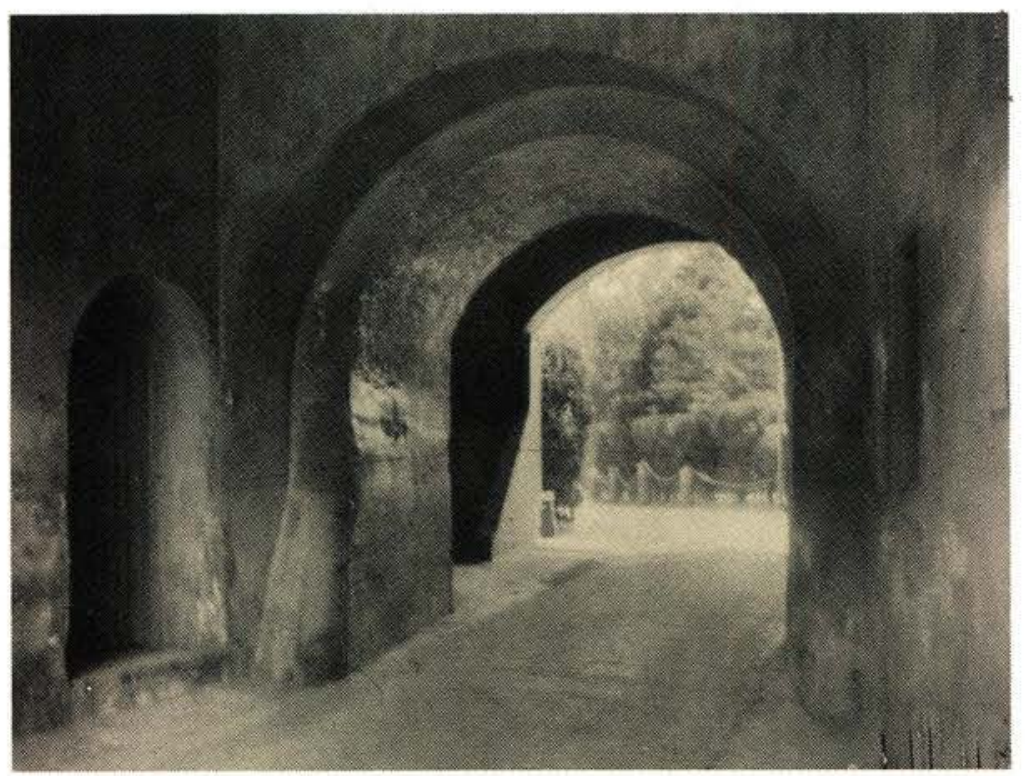

Behind the door on the left is the well. The Kat or curtain wall can be seen to the right of the door.

Agter die muur aan die linkerkant is die put. Die skermmuur kan aan die regterkant van die deur gesien word.

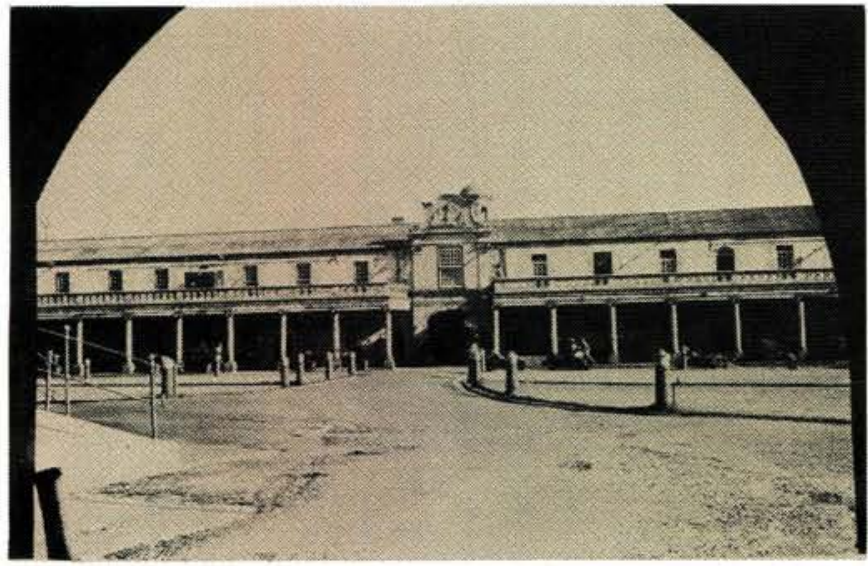

Behind " $A$ " Block is the Old Mutual Head Office completed in 1940. This photograph was probably taken during World War II.

Agter die " $A$ " blok is die hoofkwartier van Ou Mutual, wat in 1940 voltooi is. Hierdie foto is heelwaarskynlik gedurende die Tweede Wêreldoorlog geneem. 
The Inner Courtyard in April 1952.

Die Binnehof van die Kasteel in April 1952.
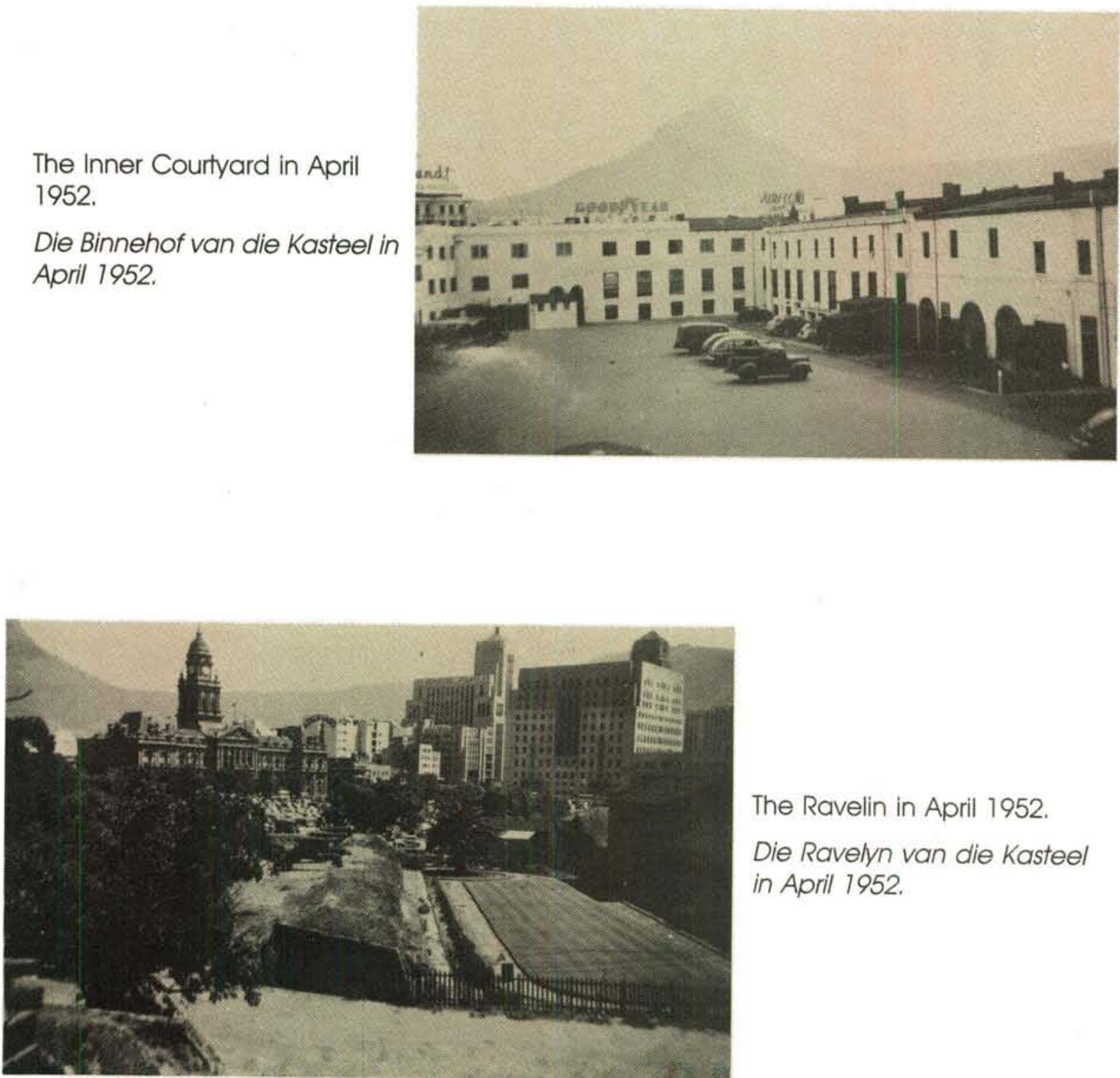

The Ravelin in April 1952.

Die Ravelyn van die Kasteel in April 1952.

Waterproofing Katzenellenbogen bastion in 1978.

Die Katzenellenbogen bastion is in 1978 waterdig gemaak.

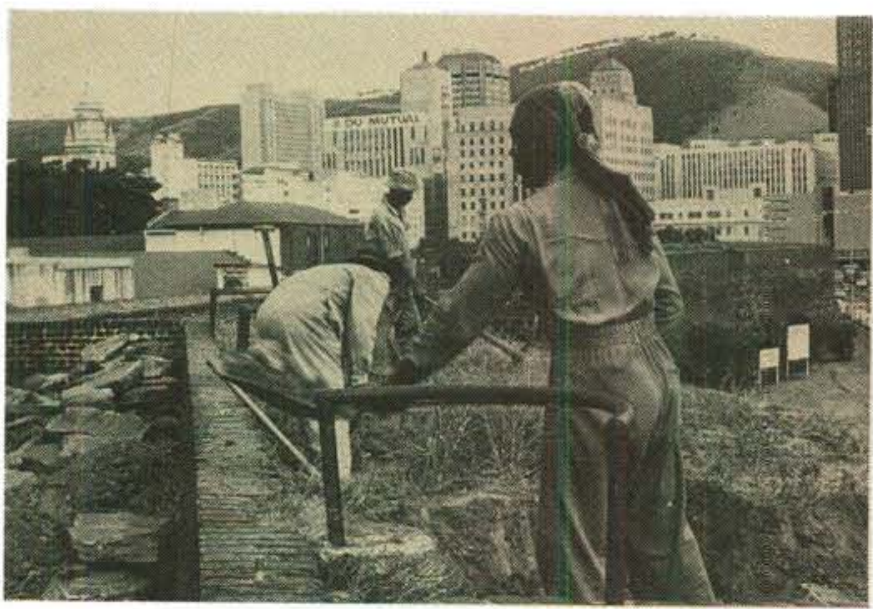




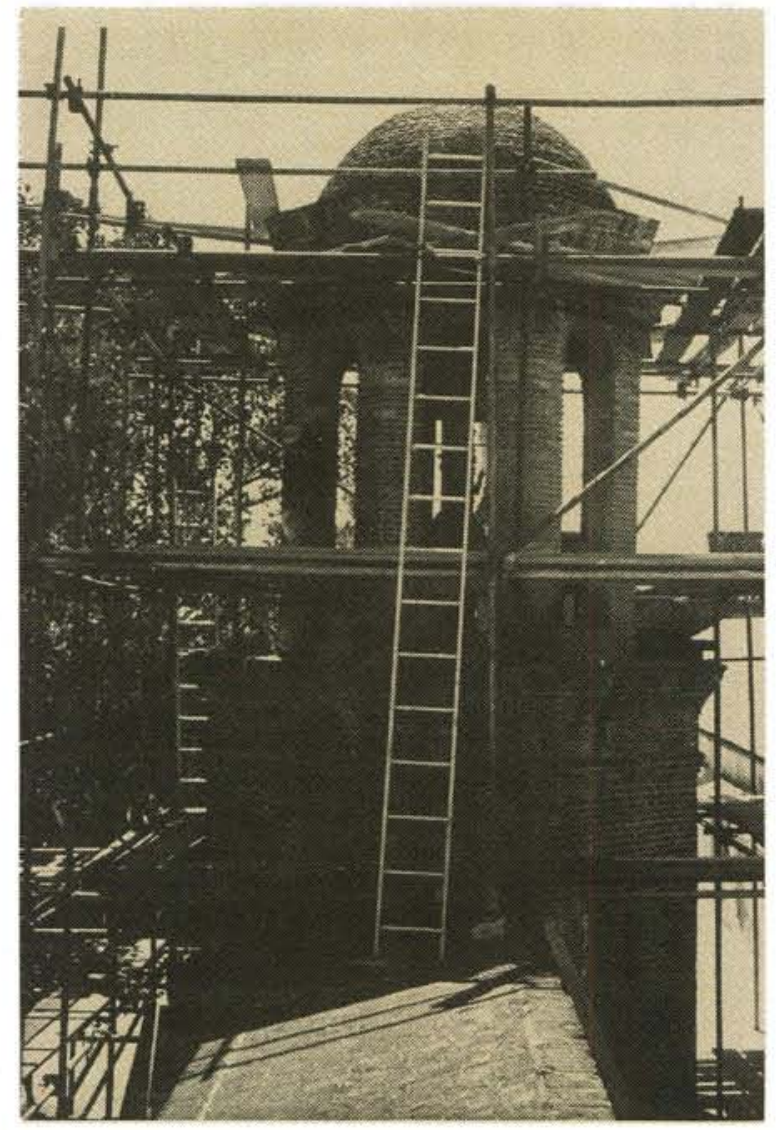

The restoration of the belfry above the main entrance to the Castle in 1979 has made it possible to ring the bell which is dated 1697 again. The bell is rung at noon on weekdays.

Restourasie aan die kloktoring wat bokant die ingang van die Kasteel is. Hierdie restourasie in 1979 het dit moontlik gemaak dat die klok wat uit 1697 dateer nou gedurende die week om 12 h00 lui.

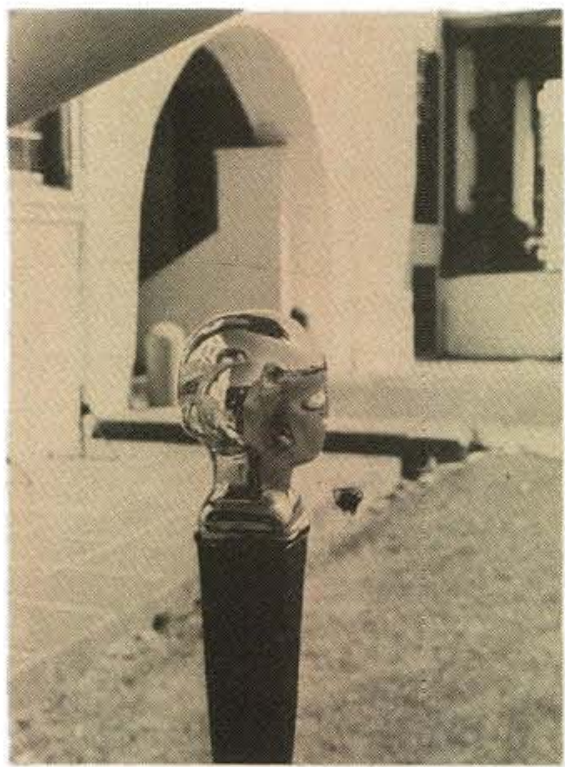

An original brass knob and a lantern at the Castle.

Van die oorspronklike koper knoppe en lanterns by die kasteel.

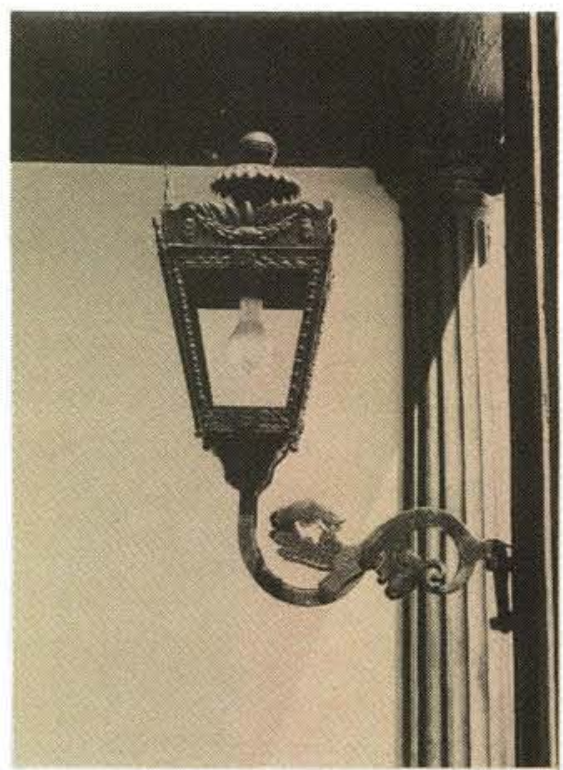




\section{Military importance of Militêre betekenis van the Castle Late 19th century die Kasteel Laat 19de eeu}

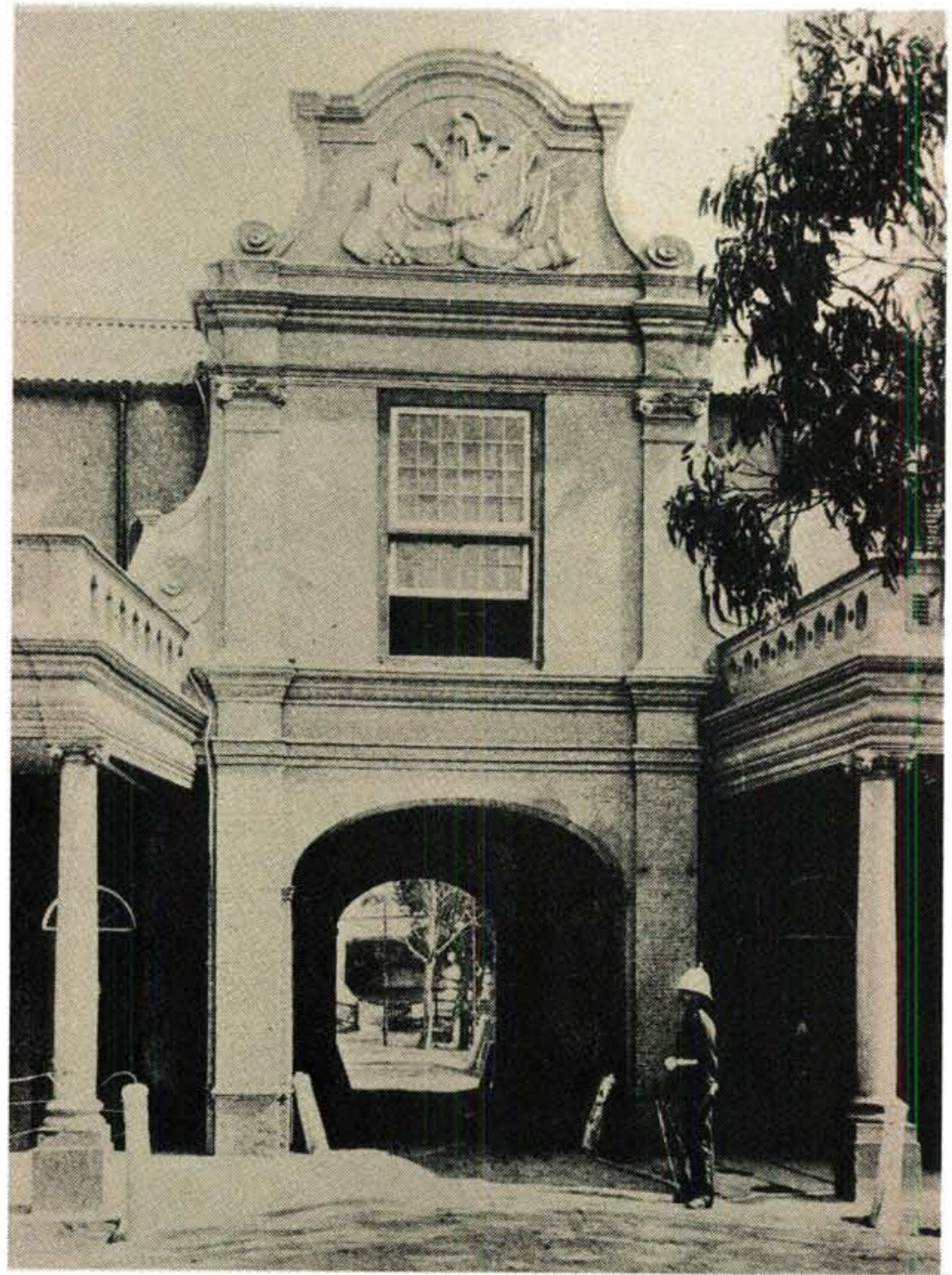

Van der Stel's gateway from the outer courtyard at the end of the 19th Century. Then as now, the guardroom was the room behind the soldier.
Van der Stel se poort vanuit die eksterne binnehof teen die einde van die 19de eeu. Toe, soos nou, was die wagkamer die vertrek agter die soldaat. 


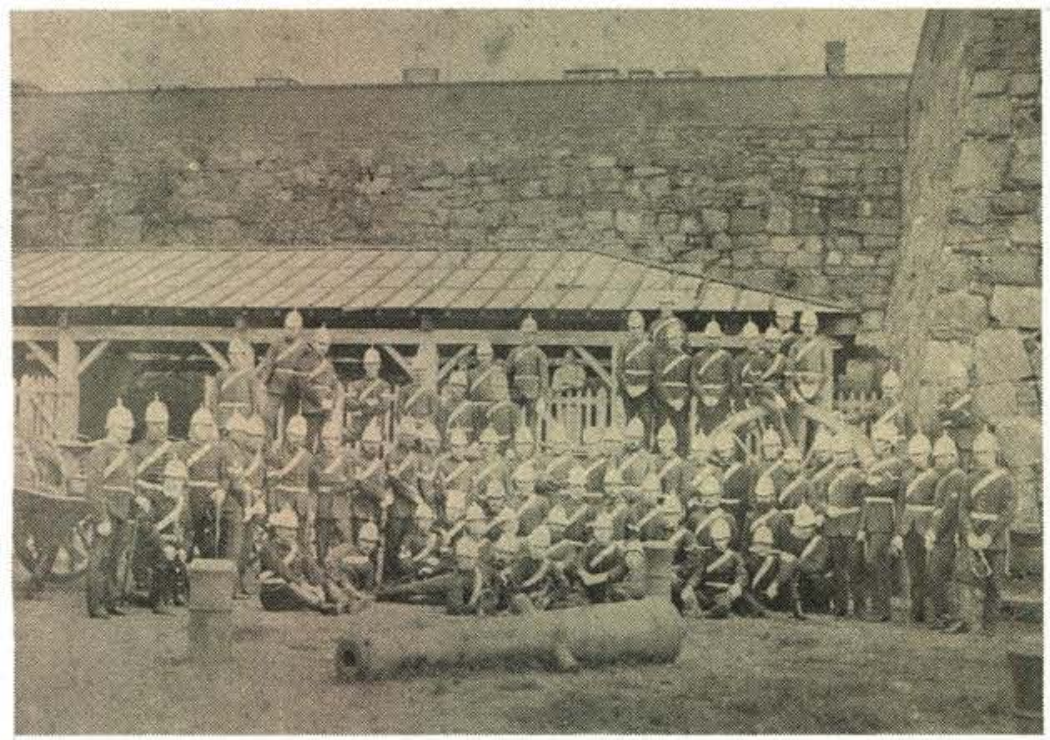

Kaapse Veldartillerie, Prince Alfred's Own Cape Town Volunteer Artillery voor die geweerloodse tussen die Nassau en Katzenellenbogen bastions. Die regiment is in 1870 uitgereik met wit helms. Hierdie beroemde SuidAfrikaanse regiment het op 26 Augustus 1857 tot stand gekom en was die oudste vrywilliger Artillerieregiment in die Britse Gemenebes.

Cape Field Artillery, Prince Alfred's Own Cape Town Volunteer Artillery in front of the gunsheds between Nassau and Katzenellenbogen bastions. The regiment was issued with white helmets in 1870. This famous South African regiment was raised on 26 August 1857 and was the oldest volunteer artillery regiment in the British Commonwealth.

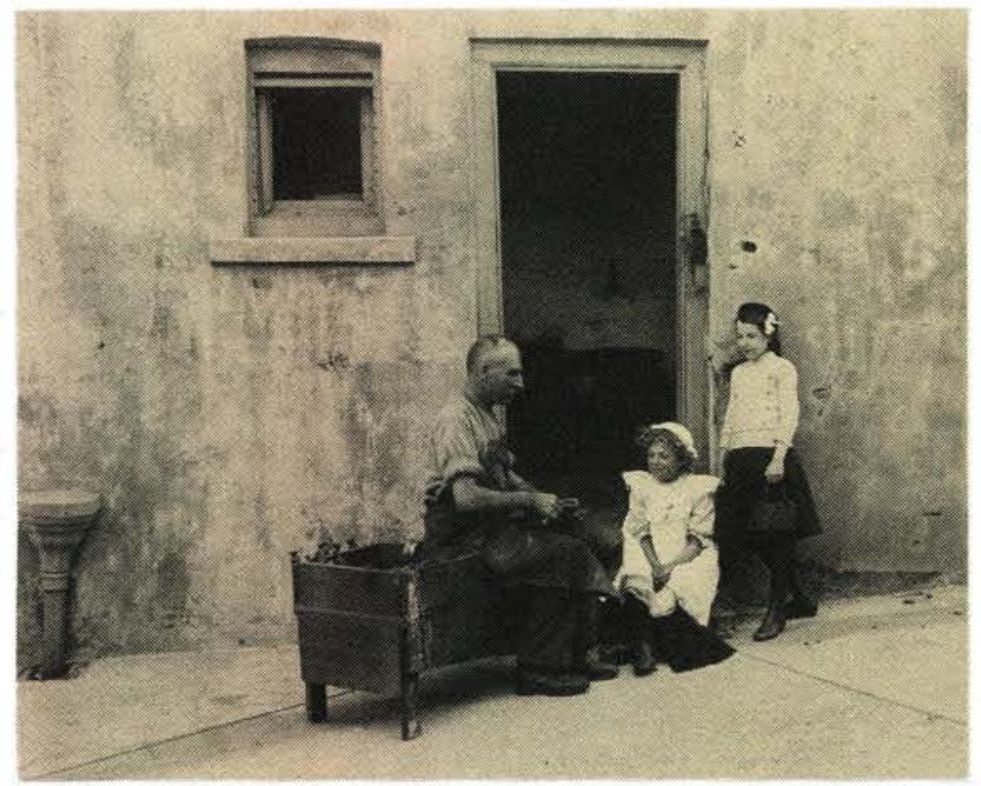

Die dogters van 'n lid van die Britse Leërgarnisoen by die Kasteel bewonder die handewerk van die regimentskoenmaker buite die werkswinkel in Nassau bastion. Binne die winkel is 'n kleretrommel wat aan 14th Company Southern Division Royal Antillery behoort het.

The daughters of a member of the British Army garisson at the Castle admiring the handiwork of the regimental shoemaker outside his shop in Nassau bastion. His bench contains compartments for his tools. Inside the shop is a clothing trunk which belonged to 14th Company Southern Royal Artillery. 


\section{Turn of the century}

\section{Eeuwisseling}

The Castle's fire engine was housed in this ground floor room in Block $\mathrm{E}$ in the outer square: The soldiers are members of the Hampshire Regiment.

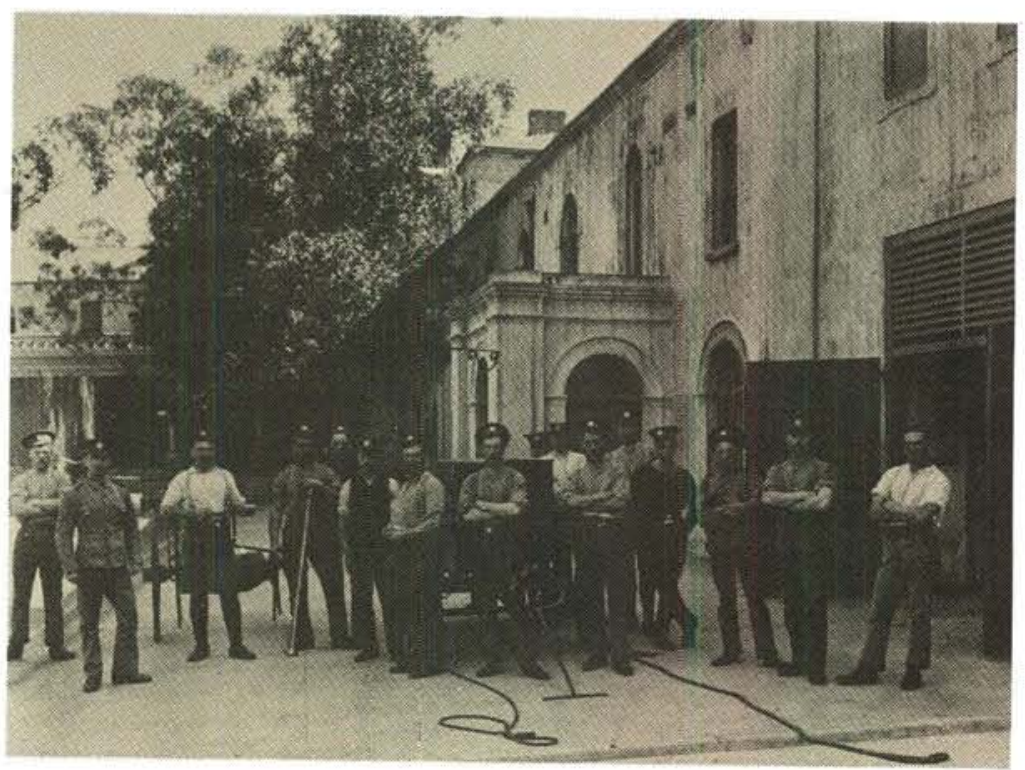

Die Kasteel se brandweenwa is in hierdie kamer op die grondvloer, E Blok in die eksterne binnehof geberg. Die soldate is lede van die Hampshire regiment.

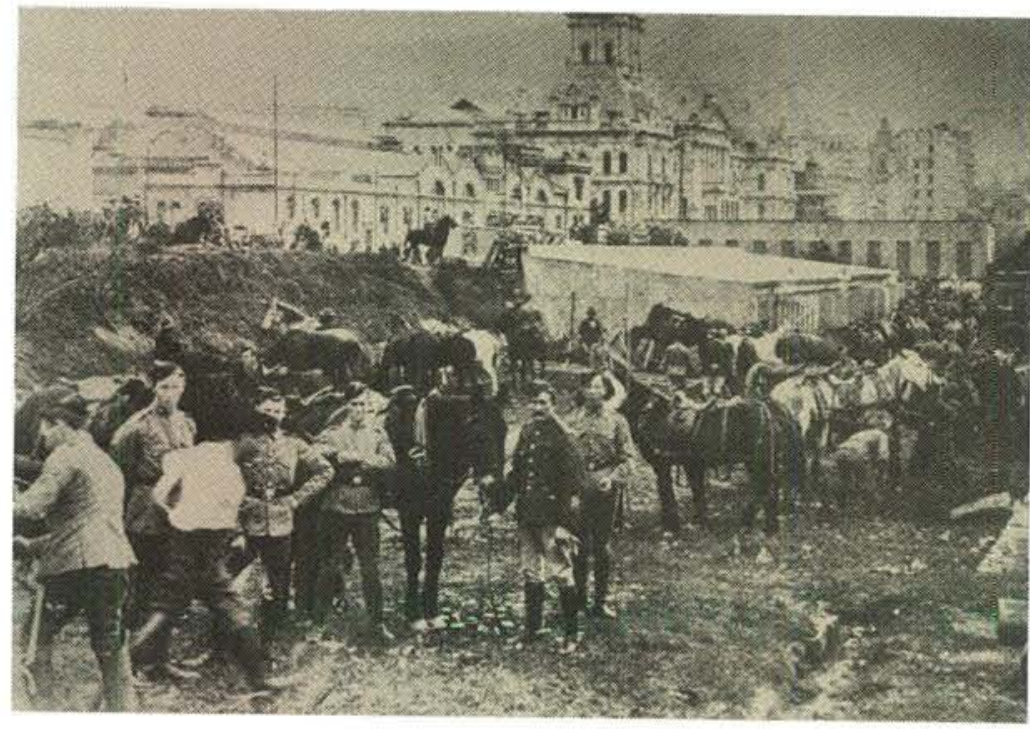

Lede van die Cape Field Artillery besig om op te saal buite die kanonloodse in die Kasteel grag in 1904. Die Ou Drilsaal en die Stadsaal kan in die agtergrond gesien word.
Members of the Cape Field Artillery saddling up outside the gunsheds in the Castle moat in 1904. The Old Drill Hall and City Hall can be seen in the background. 


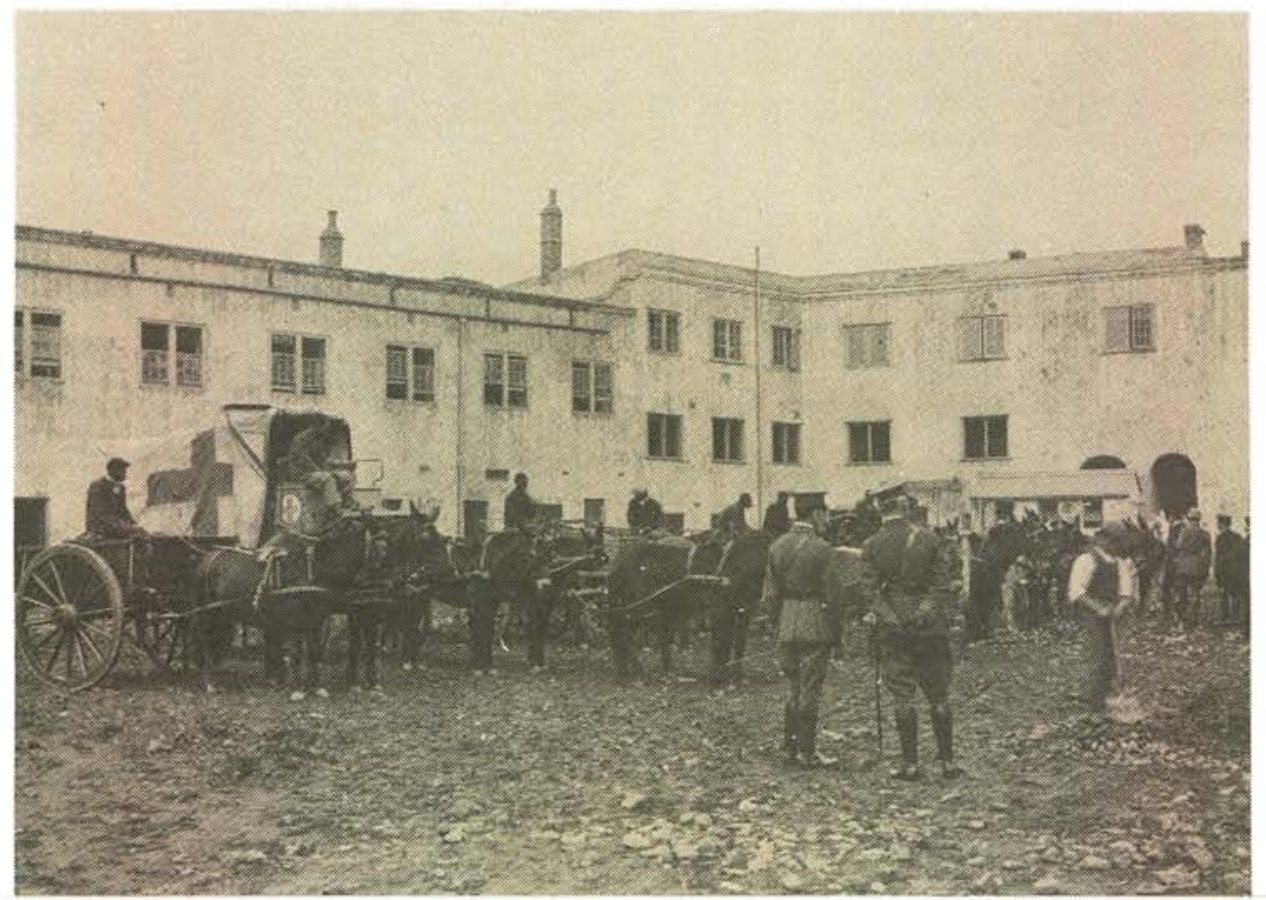

The Inner Courtyard behind Oranje bastion. Inspection of the Army Service Corps by

Major General Sir Henry Scobell, KCVO, CB. General Scobell was appointed General Officer Commanding Cape Colony District on 30 January 1909.

Die binnehof agter die Oranje bastion. Inspeksie van die Leërdienskorps deur Gentmaj Henry Scobell, KCVO, CB. Genl Scobell is aangestel as Bevelvoerder Kaapkoloniedistrik op 30 Januarie 1909.

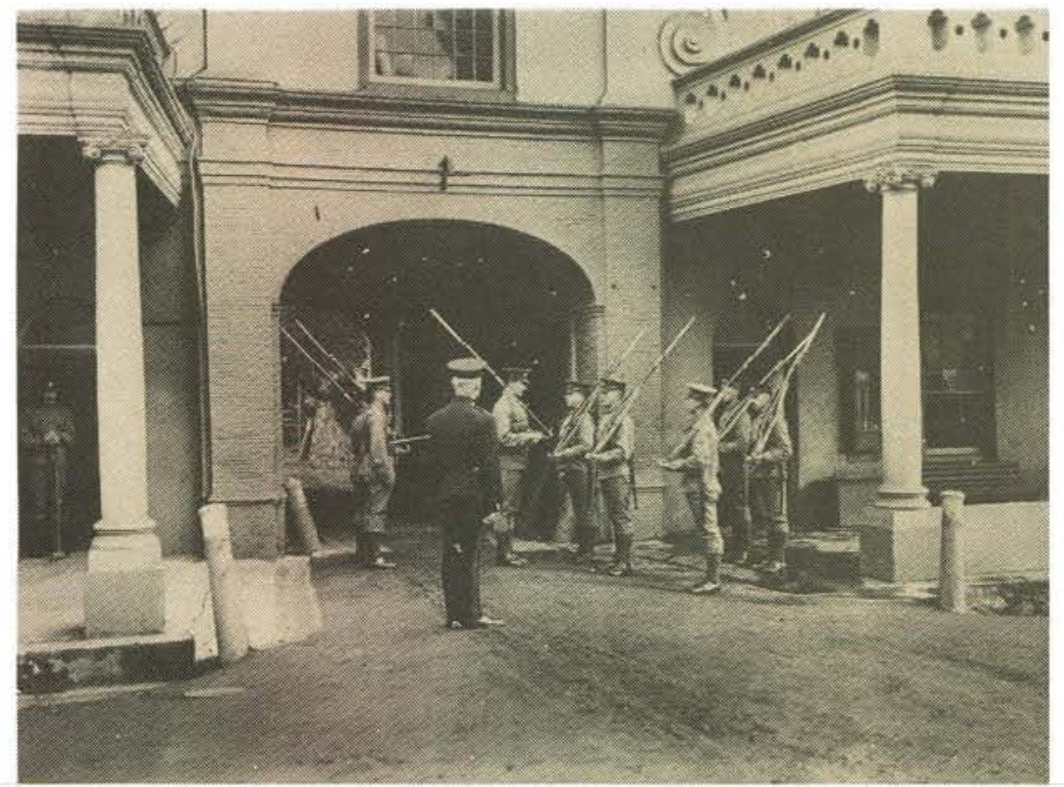

Countless soldiers have done guard duty at the Castle. The infantrymen were members of the British Garrison. Most of the latter left South Africa soon after the outbreak of the First World War.

Talle soldate het wagdiens gedoen by die Kasteel. Hierdie Infanteriesoldate was lede van die Britse Garnisoen. Die grootste deel van laasgenoemde het Suid-Afrika verlaat met die uitbreek van die Eerste Wêreldoorlog. 
Major General Sir Henry Scobell KCVO, $\mathrm{CB}$, extreme right with Col W.H. Rycroft, $\mathrm{CB}$ (Assistant Adjutant and Quartermaster General) and Lt Col S. Hickson, RAMC (Senior Medical Officer) on the balcony outside the former's office. Both Maj Gen Scobell and Maj Gen H.S.L. Ravenshaw, CB, CMG died while serving as GOC at the Castle.

Genl-maj Sir Henry Scobell, KCVO, CB heel regs met Kol W.H. Rycroft, $C B$ (Assistent Adjudant en KwartiermeesterGeneraal en Lt-kol S. Hickson, RAMC (Senior Mediese Offisier) buite eg se kantoor. Beide Genl-maj Scobell en Genl-maj H.S.L. Ravenshaw, CB, CMG het tydens hulle dienstydperk as bevelvoerende offisier by die Kasteel gesterf.
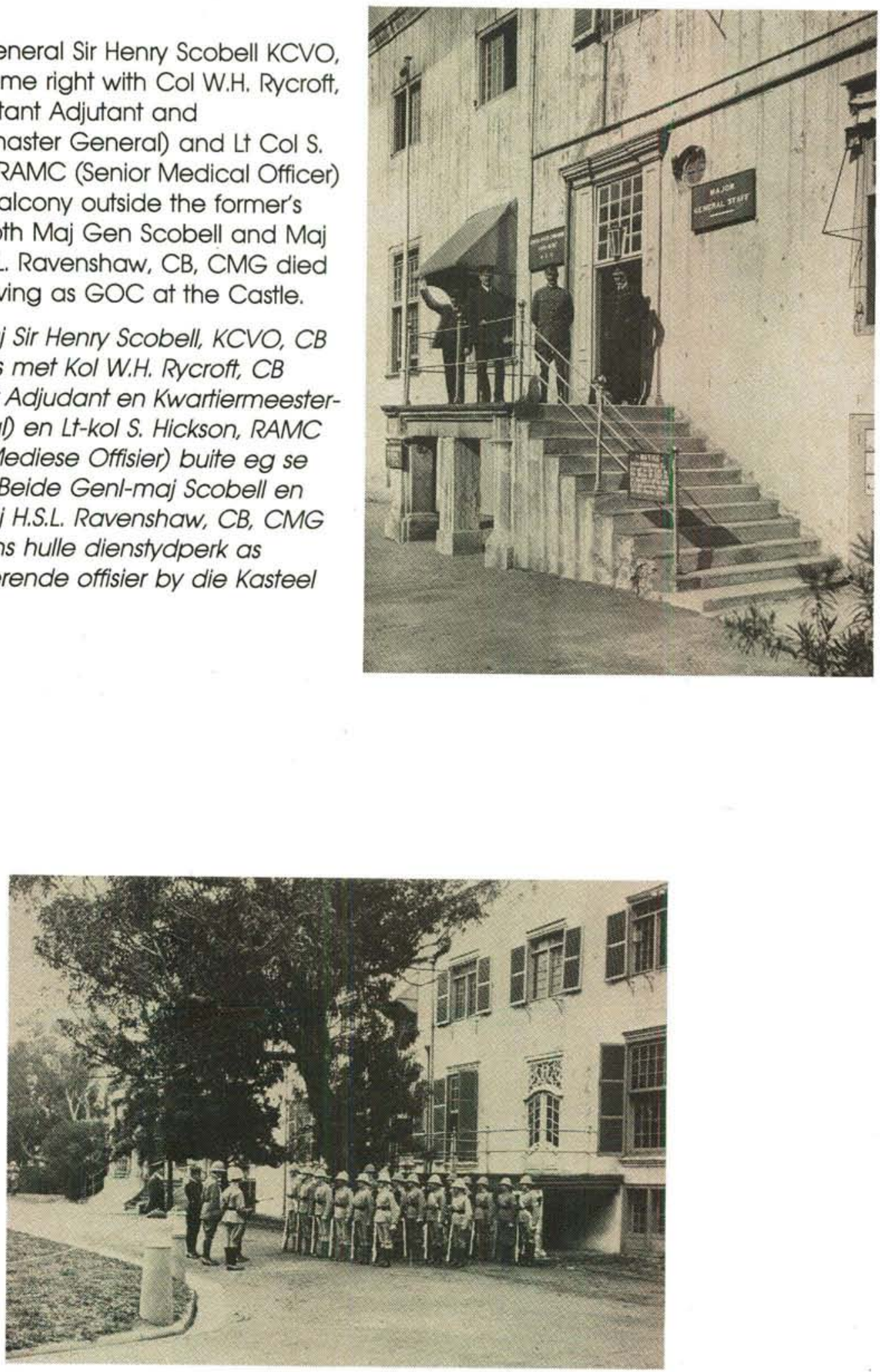

Maj Gen Sir Henry Scobell, General Officer Commanding Cape Colony District, addressing troops in the outer courtyard in 1911. The "Nieuwe Kat" balcony is hidden by the gum tree.

Genl-maj Sir Henry Scobell, Bevelvoerder Kaapkoloniedistrik, spreek troepe toe in die eksterne binnehof in 1911. Die "Nieuwe Kat" balkon word versteek agter 'n Gomboom. 


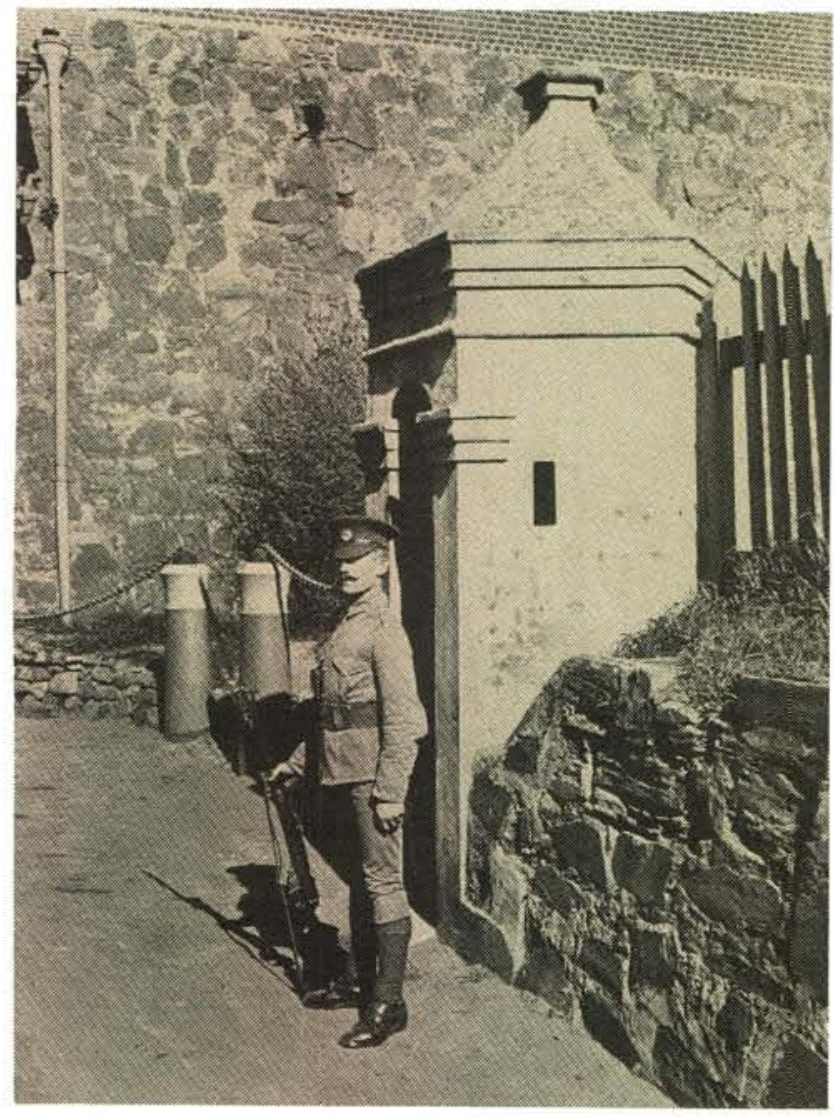

British sentries outside the Van der Stel gateway seen from without and within.

Britse wagte buite die Van der Stel ingang, gesien vanaf die buite- en binnekant.

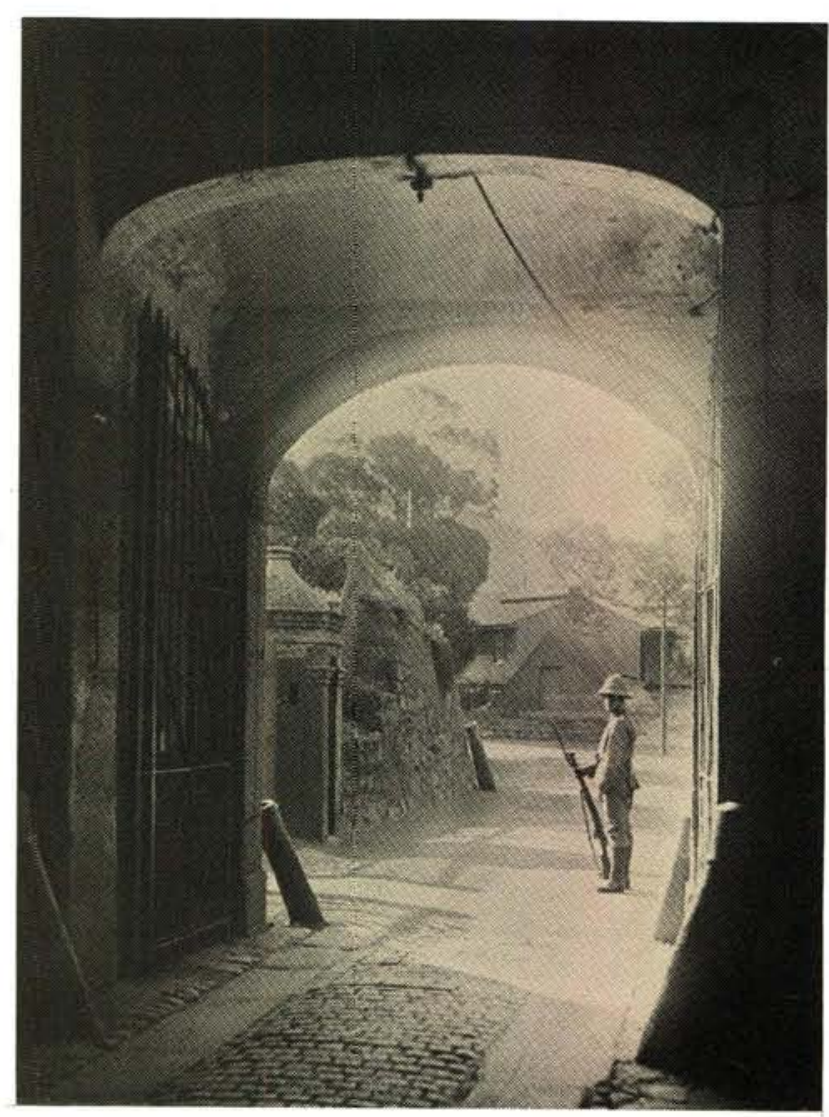




\section{First World War}

\section{Eerste Wêreldoorlog}

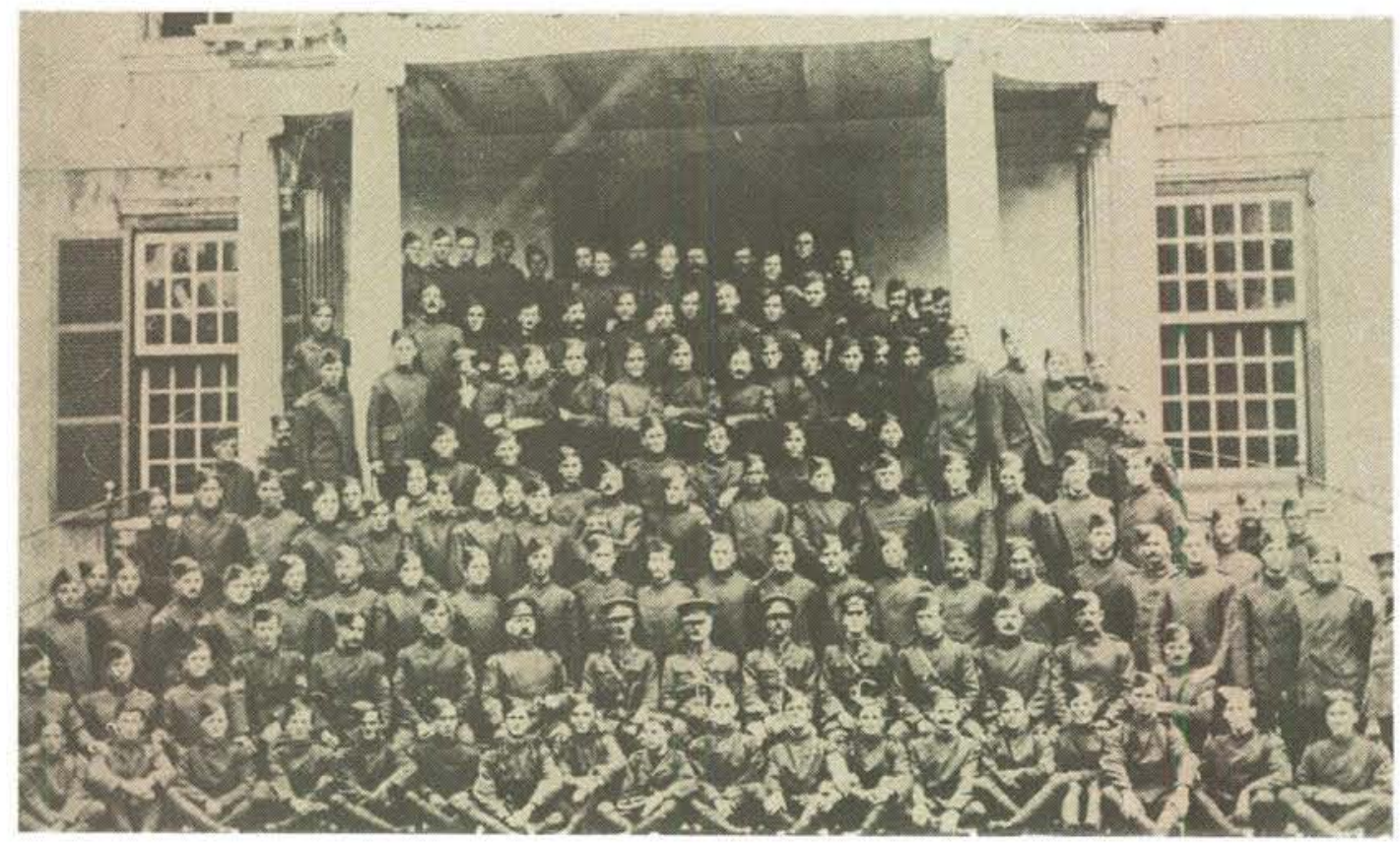

The SA Aviation Corps, predecessor of the SA Air Force, photographed in front of the

"Nieuwe Kat" balcony prior to the German South West Africa Campaign in 1914.

Die SA Vlieënierskorps, waaruit die SA Lugmag ontstaan het, afgeneem voor die "Nieuwe Kat" balkon net voor die Duits Suidwes-Afrika-veldtog in 1914.

Lt Col E.I.D. Gordon, OBE, was the British Garrison Adjutant at the Castle in 1914 and served there again during the Second World War in the SA Staff Corps.

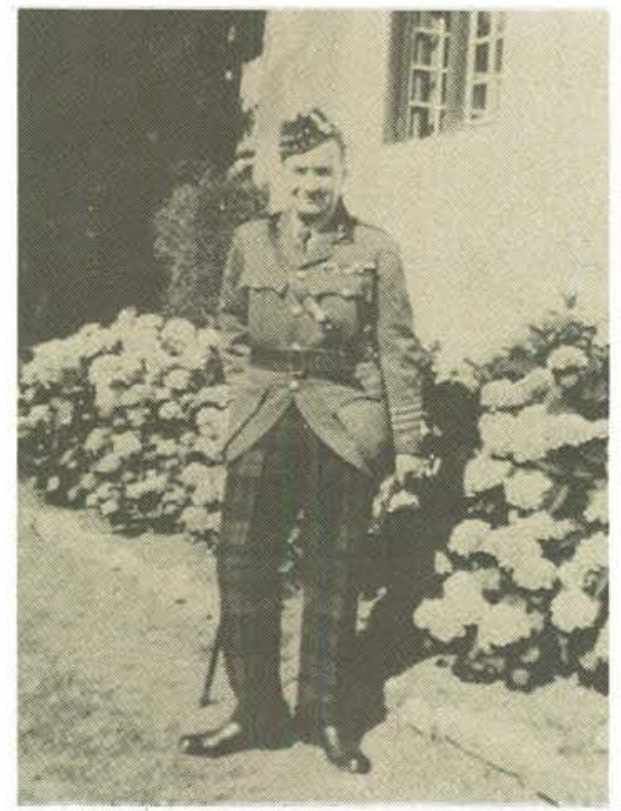

Lt-kol E.I.D. Gordon, OBE was Britse Garnisoen Adjudant by die Kasteel in 1914 en het weer daar gedien gedurende die Tweede Wêreldoorlog, in die SA Stafkorps. 


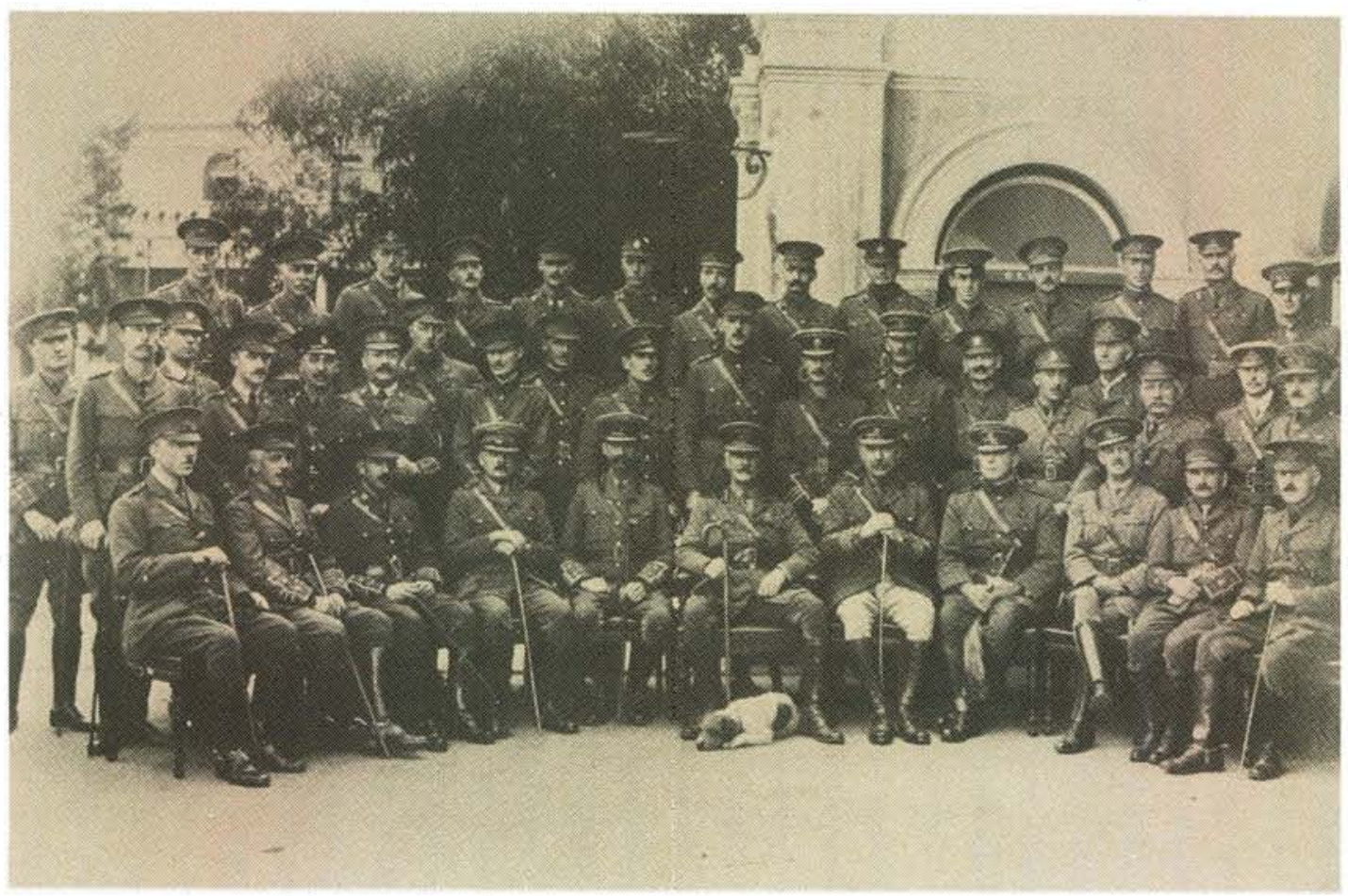

British and South African officers of the Garrison in 1966. In the centre is the General Officer Commanding SA Military Command Maj Gen C.W. Thompson, CB, DSO. The last officer on the top right head side standing is capt Len Beyers who was later Lt Gen and Chief of the General Staff from 1949-50.

Offisiere van die SA Militêre Kommandement afgeneem by die Kasteel in 1916. Op die foto verskyn: Genl-maj C.W. Thompson, die Britse Bevelvoerder (sittende); en kapt Len Beyers (die laaste offisier aan die regterkant in die agterste ry) wat vanaf 1949-1950 Hoof van die Generale Staf was. 


\section{The period 1918-1939}

\section{Die tydperk 1918-1939}

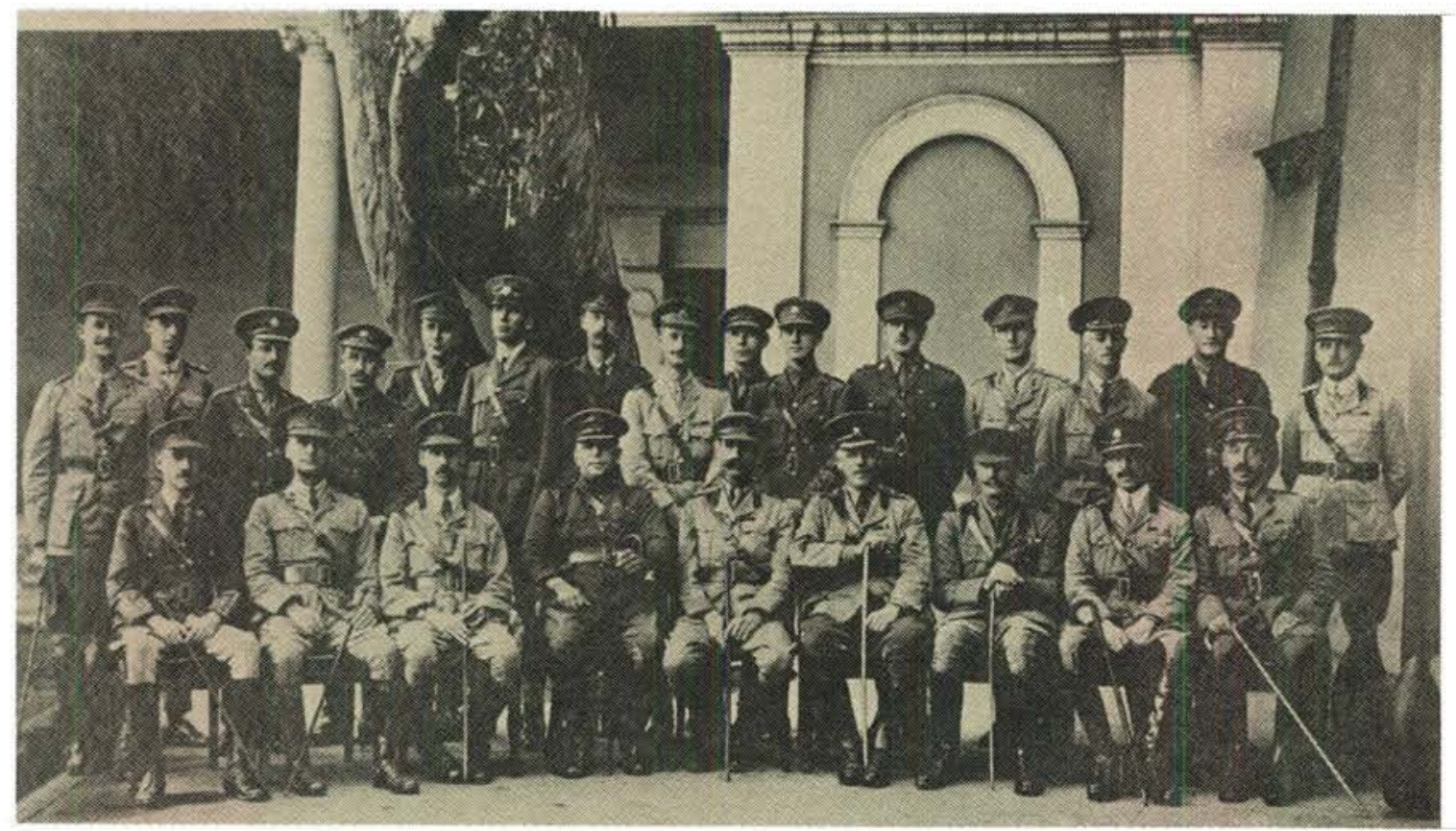

Offisiere van Tafelbaai se vestingwerke April 1919.

Officers Table Bay Defence April 1919.

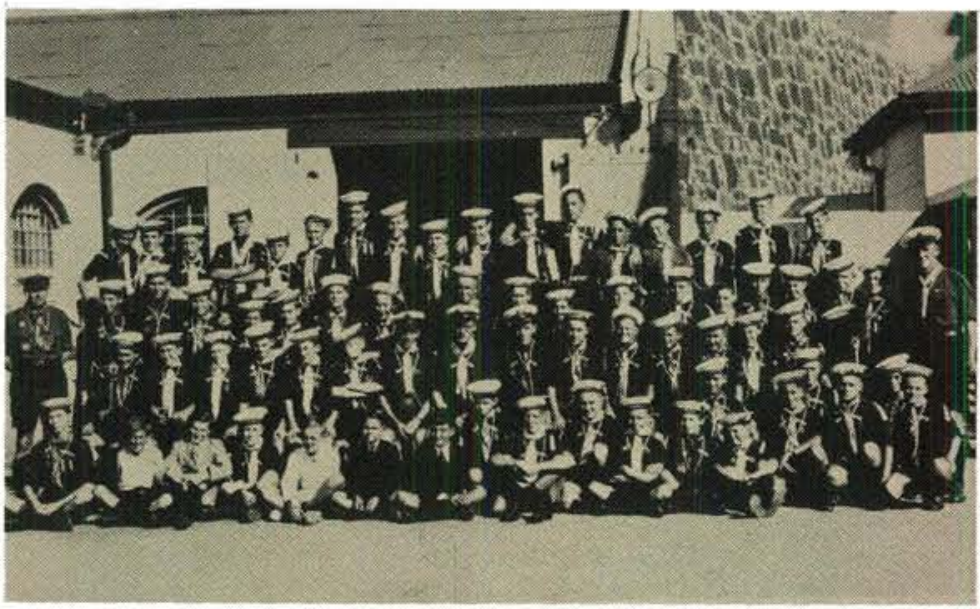

Cape Town Sea Scouts at the RNVR at the Castle.

Vlootverkenners van Kaapstad voor die Britse Koninklike Vlootbasis by die Kasteel. 


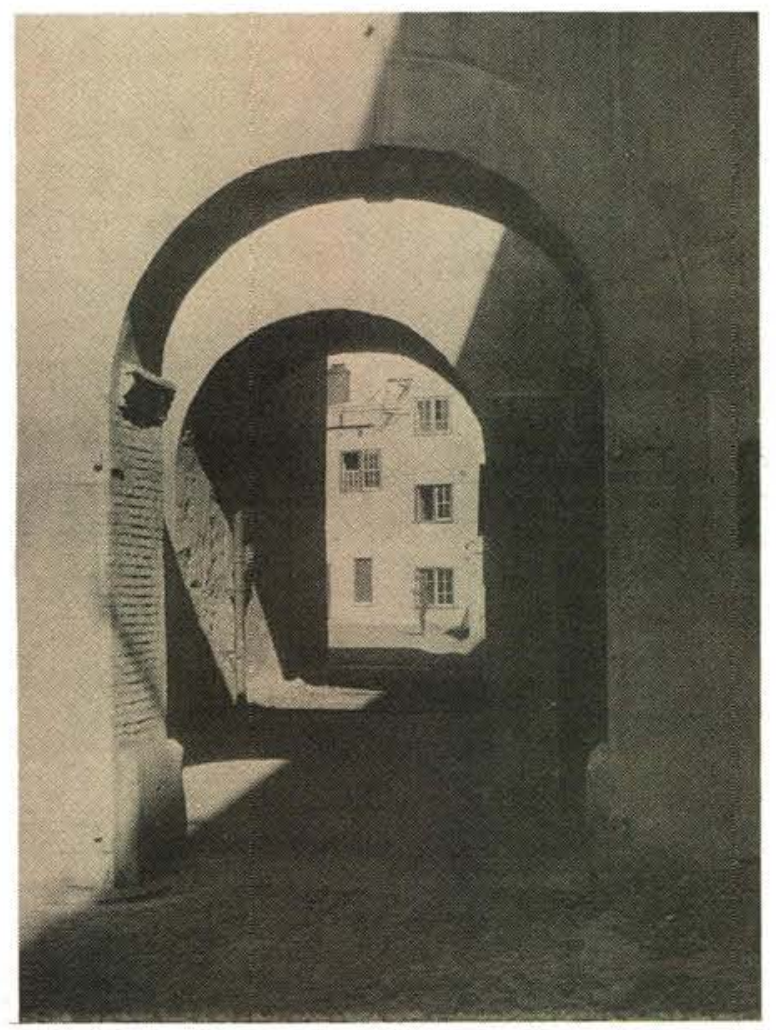

The door to the right of the notice board is the oldest door in South Africa. The photograph was taken after the transfer of the building to the South African Government on 1 December 1921.

Die deur aan die regterkant van die kennisgewingbord is die oudste deur in Suid-Afrika. Hierdie foto is geneem na die oordrag van die gebou aan die SuidAfrikaanse regering op 1 Desember 1921.

Headquarters Staff Cape Peninsula Garrison in August 1925. In the centre seated is Brigadier General W.E.C. Tanner who served three terms as Officer Commanding at the Castle. The third and sixth seated officers Col F.G. Harvey and Capt P. de Waal (SAN) were later also to occupy this coveted post.

Personeel van die Kaapse Skiereiland garnisoen afgeneem voor hulle hoofkwartier in Augustus 1925. In die middel sit briggenl W.E.C. Tanner, wat vir drie termyne bevelvoerende offisier by die Kasteel was. Die derde en sesde sittende offisiere, kol F.G. Harvey en kapt P. de Waal (SAV) het later ook dié pos beklee.

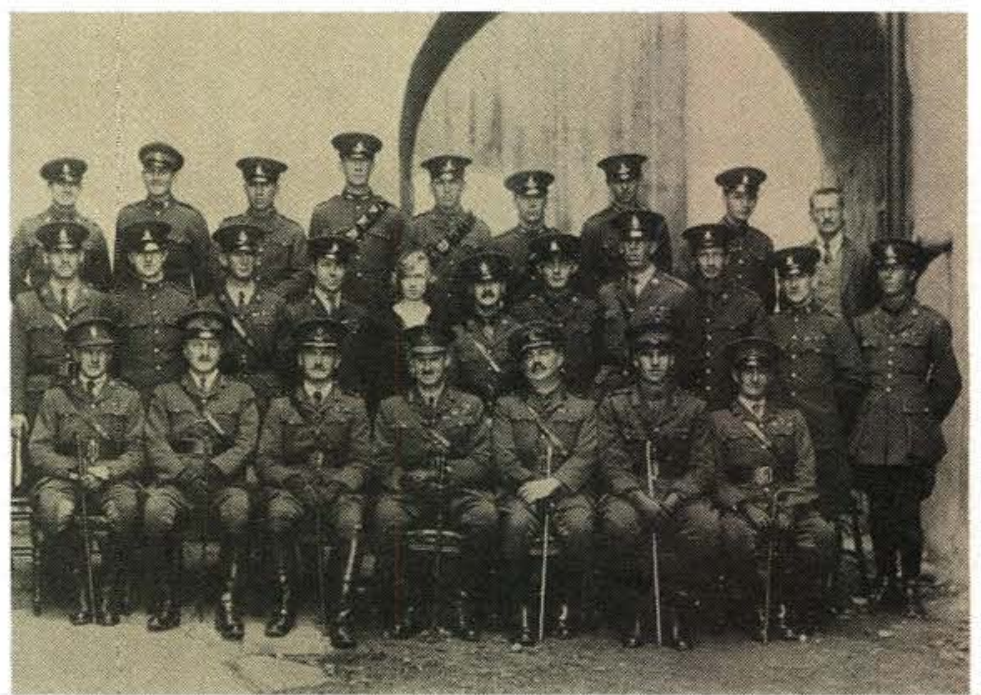




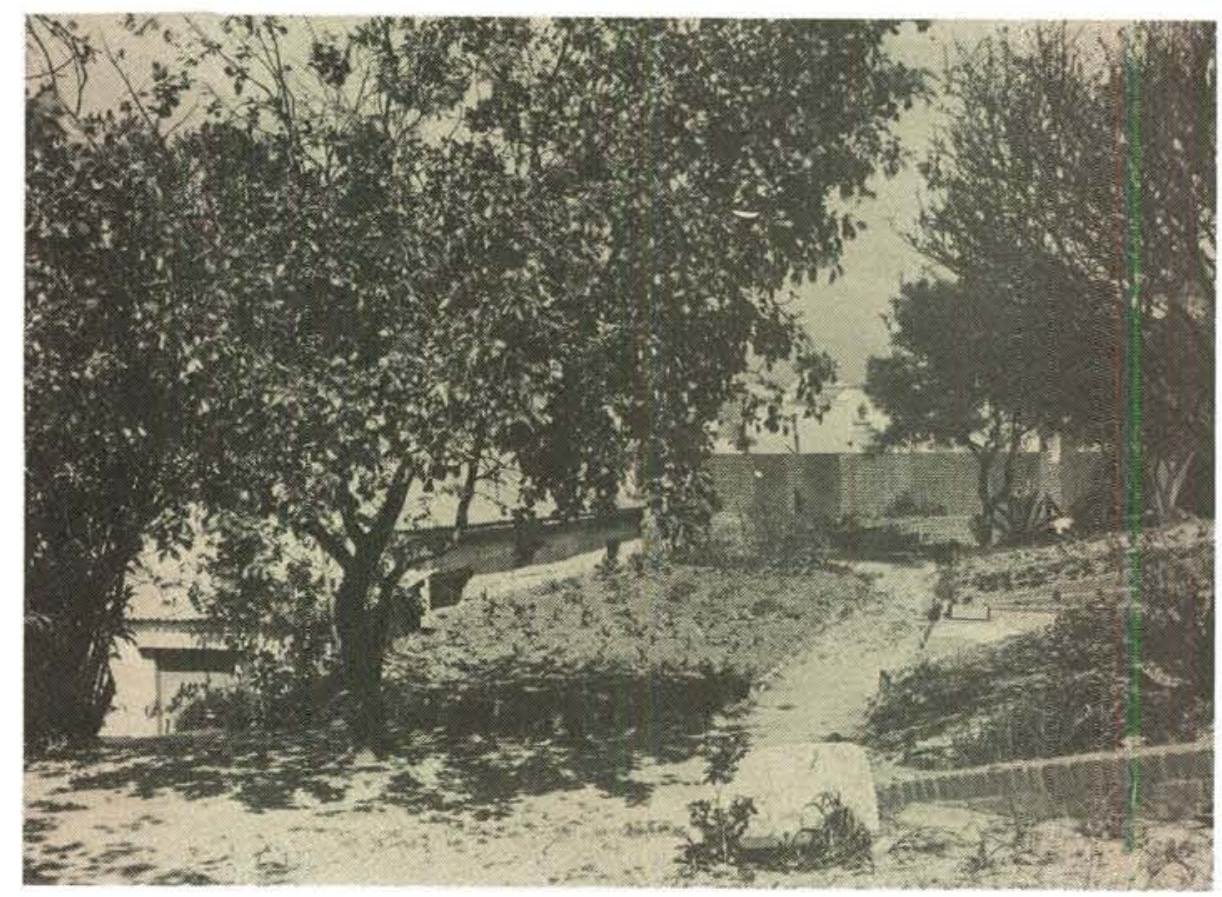

A garden on Buren bastion.

'n Tuin op Buren bastion.

The Union Jack on Leerdam bastion. At sunset a band or the duty bugler (seen here on the extreme right) sounded the retreat.

Die Union Jack op Leerdam bastion. Met sonsondergang het 'n orkes of beuelblaser (heel regs) die aandsinjaal geblaas.

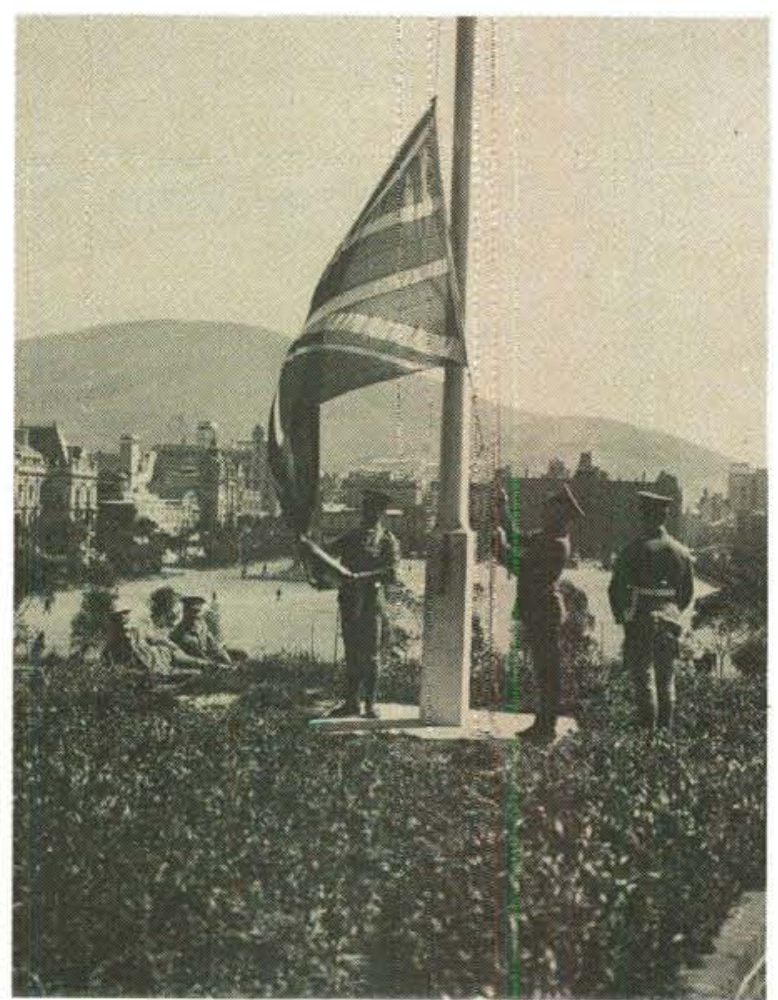




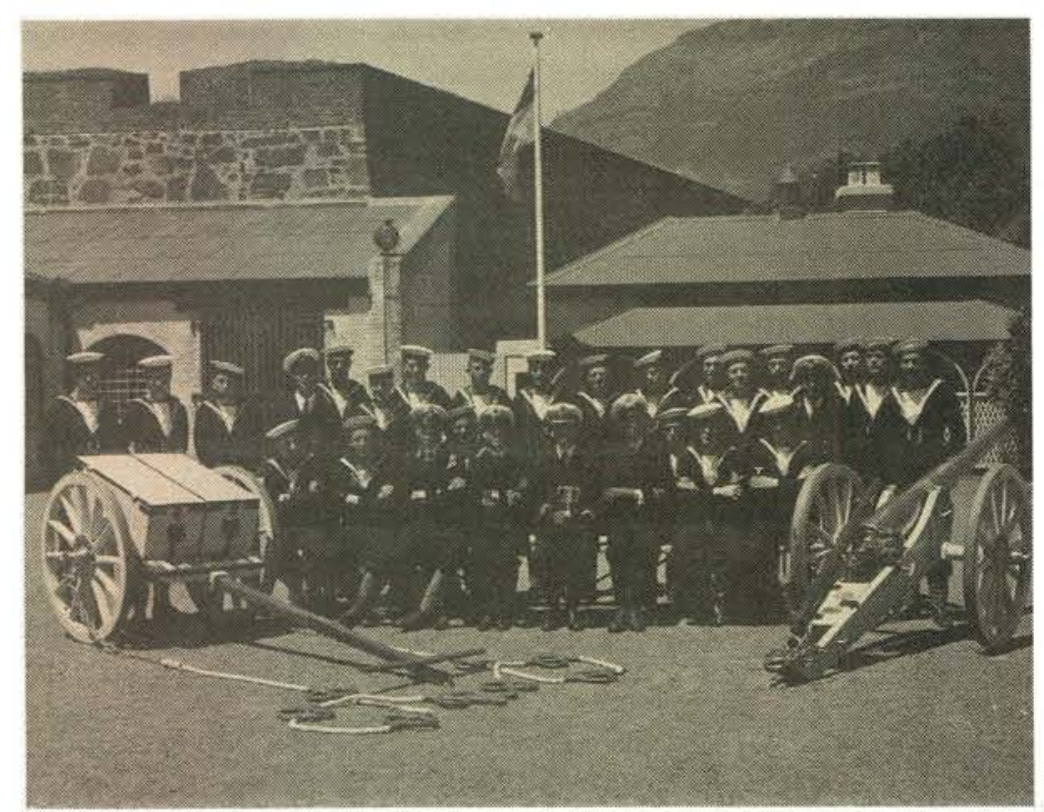

Commander W.J. Copenhagen and members of the team which won the Admiral's Cup as well as the Cup for the fastest time in the gun crew competition at the Empire Exhibition in Johannesburg in 1936. The photograph was taken at the RNVR base at the Castle.

Kommandeur W.J. Copenhagen en lede van die span wat die Admiraalsbeker en die beker vir die vinnigste tyd in die kanonspankompetisie tydens 'n uitstalling in Johannesburg in 1936 gewen het. Die foto is voor die Britse vlootbasis se hoofkwartier in die Kasteel geneem.

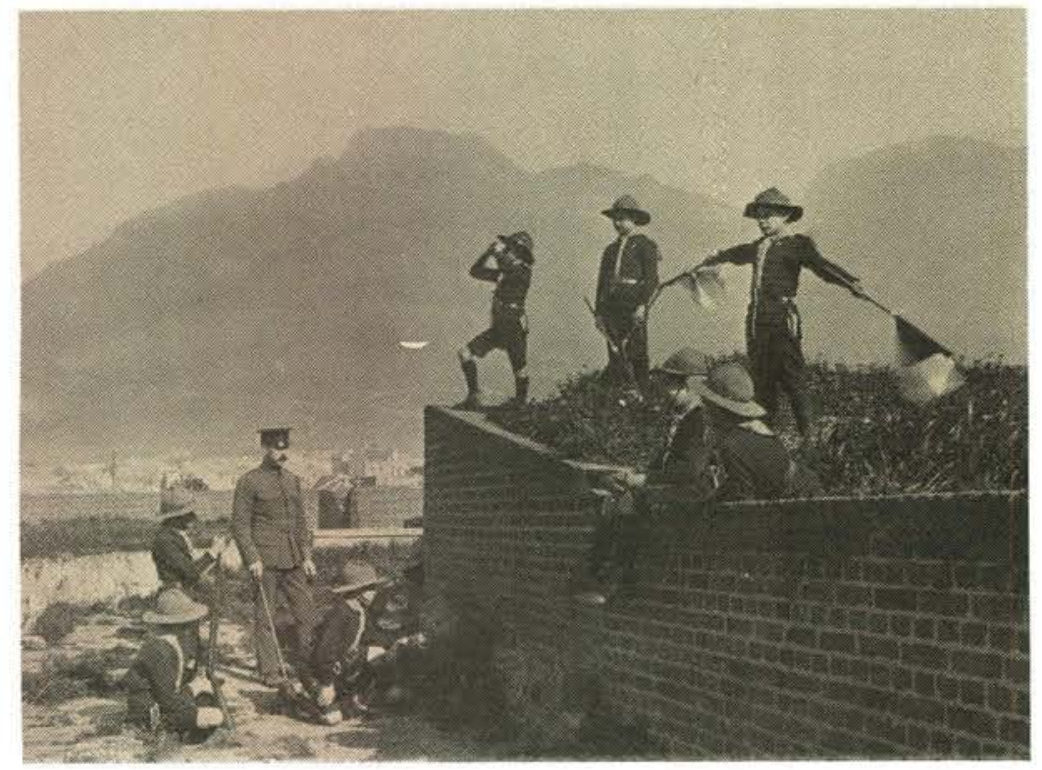

The Castle had its own Boy Scout Troop from 1909-1916.

Die Kasteel het sy eie Padvinder troep gehad van 1909 tot 1916. 


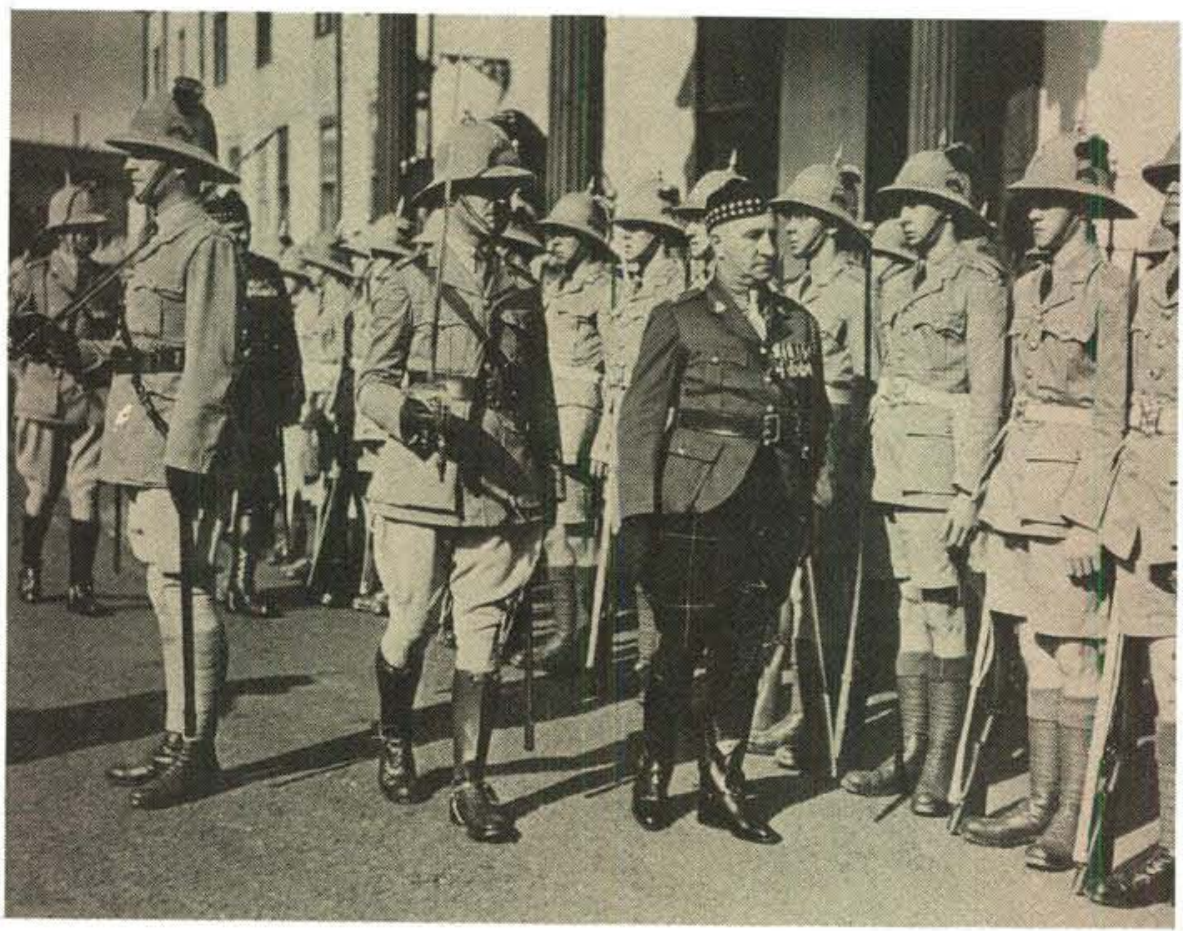

On 26 September 1936 the band of the Duke of Edinburgh's Own Rifles was revived.

After an impressive reunion parade on the Grand Parade Lt Col W.D. Hearn, MC, VD accompanied by the Officer Commanding the Dukes, Lt Col C. Graham Botha inspected the regiment in the outer square at the Castle.

Op 26 September 1936 het die orkes van die Duke of Edinburgh's Own Rifles herleef. $N a ́$ 'n indrukwekkende optog ter viering van die hereniging, het Ht-kol W.D. Hearn, MC, VD, vergesel deur die bevelvoerende offisier van die Dukes, It-kol C. Graham Botha, die regiment in die buitenste plein van die Kasteel geinspekteer. 


\section{Second World War Tweede Wêreldoorlog}

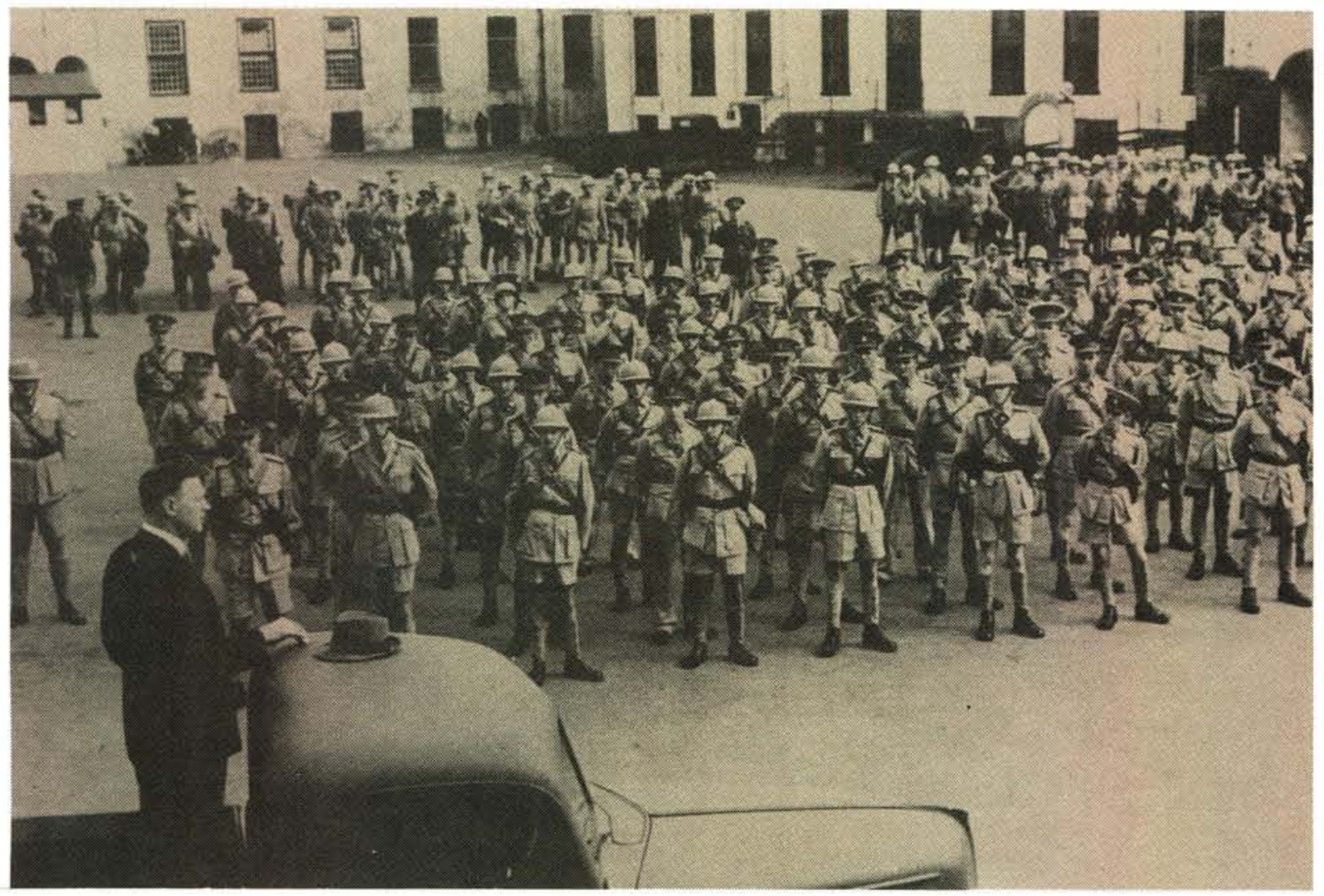

Troops being addressed by his Worship the Mayor of Cape Town, Councillor W. Brinton, in the Inner Courtyard before marching to Cape Town Station to entrain on 6 December 1939.

Soldate word in die binnehof deur die burgemeester van Kaapstad, Raadslid W. Brinton, toegespreek voor hul vertrek op 6 Desember 1939 vanaf Kaapstad stasie.

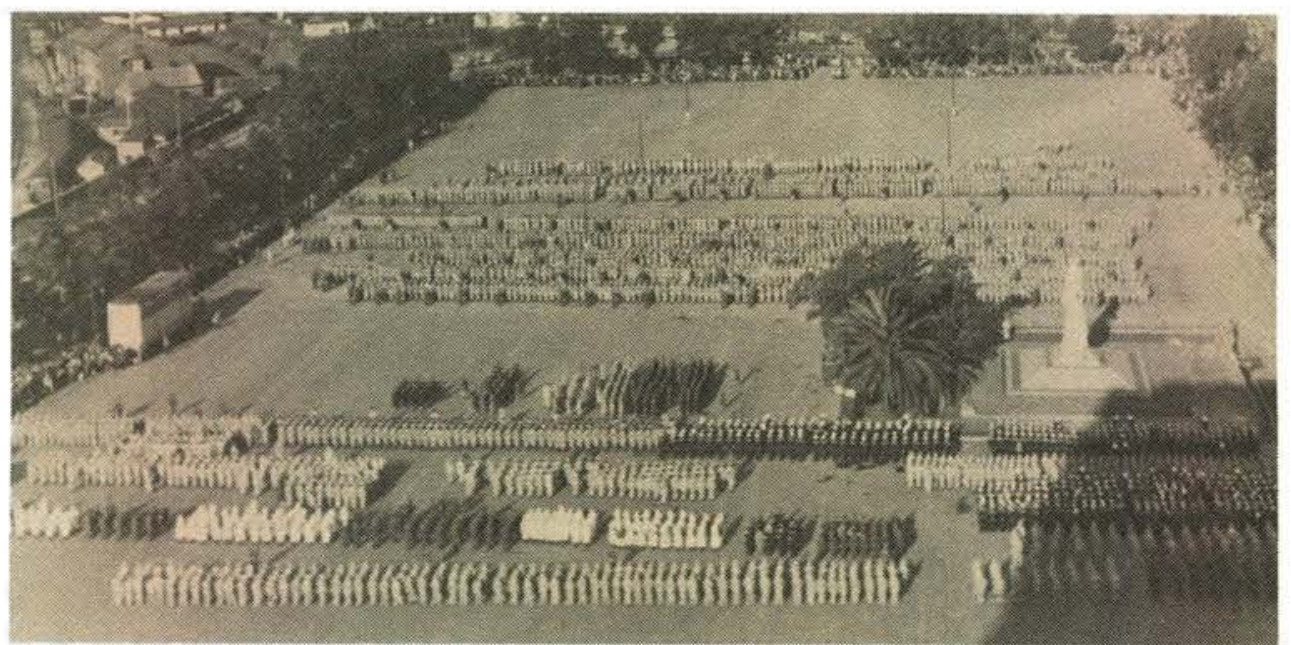

Union Day Parade circa 1939. The medical huts under the Leerdam bastion in which thousands of South Africa's World War II volunteers were examined can clearly be seen.

Uniedag Parade 1939. Die mediese hutte onder die Leerdam bastion waarin duisende van Suid-Afrika se oorlogsvrywilligers ondersoek is, is duidelik sigbaar. 
Rear-Admiral G.W. Halifax, CMG, whose work at the Castle from October 1939 until January 1940 ensured that South Africa succeeded in its second attempt to establish a navy.

Skout-admiraal G.W. Halifax, CMG, het tussen Oktober 1939 en Januarie 1941 baanbrekerswerk by die Kasteel verrig en het verseker dat SA se tweede poging om 'n vloot tot stand te bring, slaag.
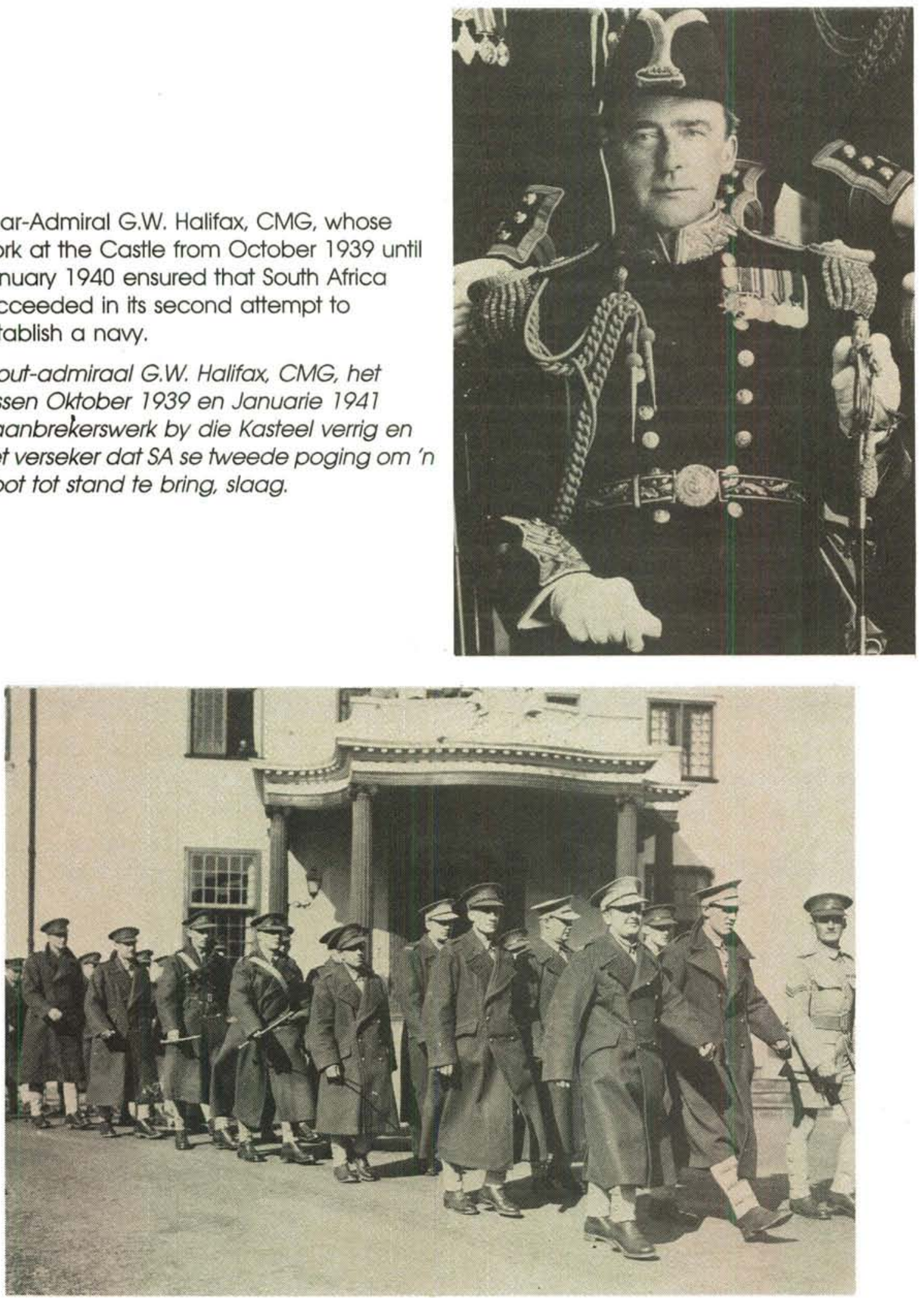

2nd Anti-Aircraft Regiment march out of the Castle to the Cape Town Station on 17 June 1940. After senvice in Abyssinia this Cape Town Sportsman's Regiment served in the Western Desert and was captured when Tobruk fell. 2de Lugafweerregiment marsjeer by die Kasteel uit na die Kaapstadstasie op 17 Junie 1940. Na diens in Abessinië het hierdie regiment in die Westelike Woestyn diens gedoen en is gevange geneem met die val van Tobruk. 


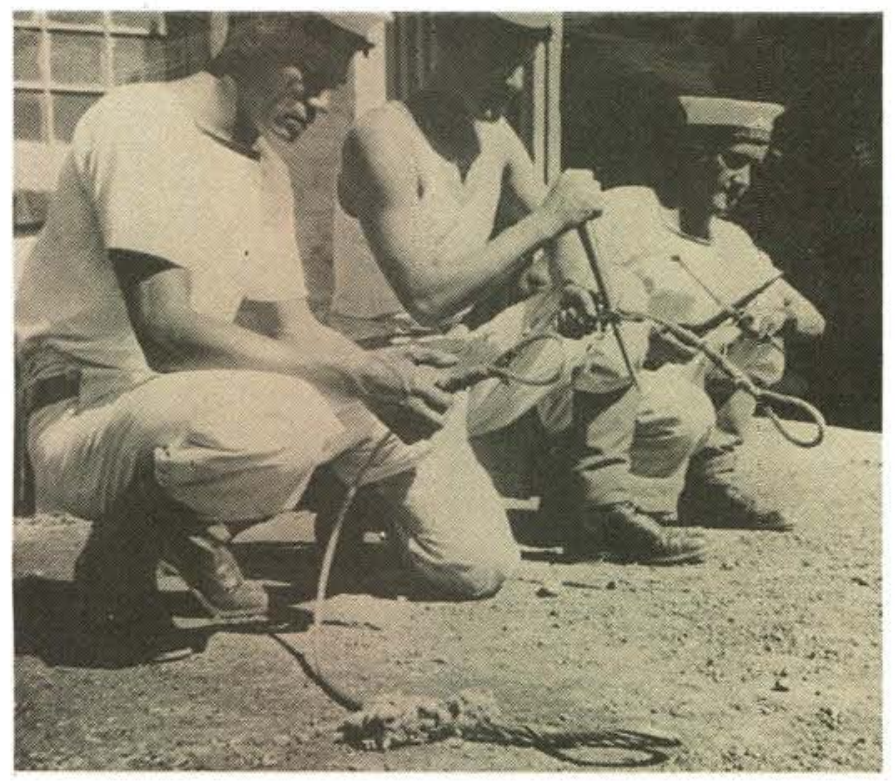

Seaward Defence Force free ratings under training at the Naval Base at the Castle. By 1942 the base was too small and the Navy moved out to Pollsmoor and HMSAS Unitie in the Table Bay Harbour.

Manskappe van die Vloot ondergaan opleiding by die Vlootbasis by die Kasteel. Teen 1942 het die Vlootbasis na Pollsmoor en die HMSAS Unitie in Tafelbaai verskuif aangesien die basis by die Kasteel te klein geword het.

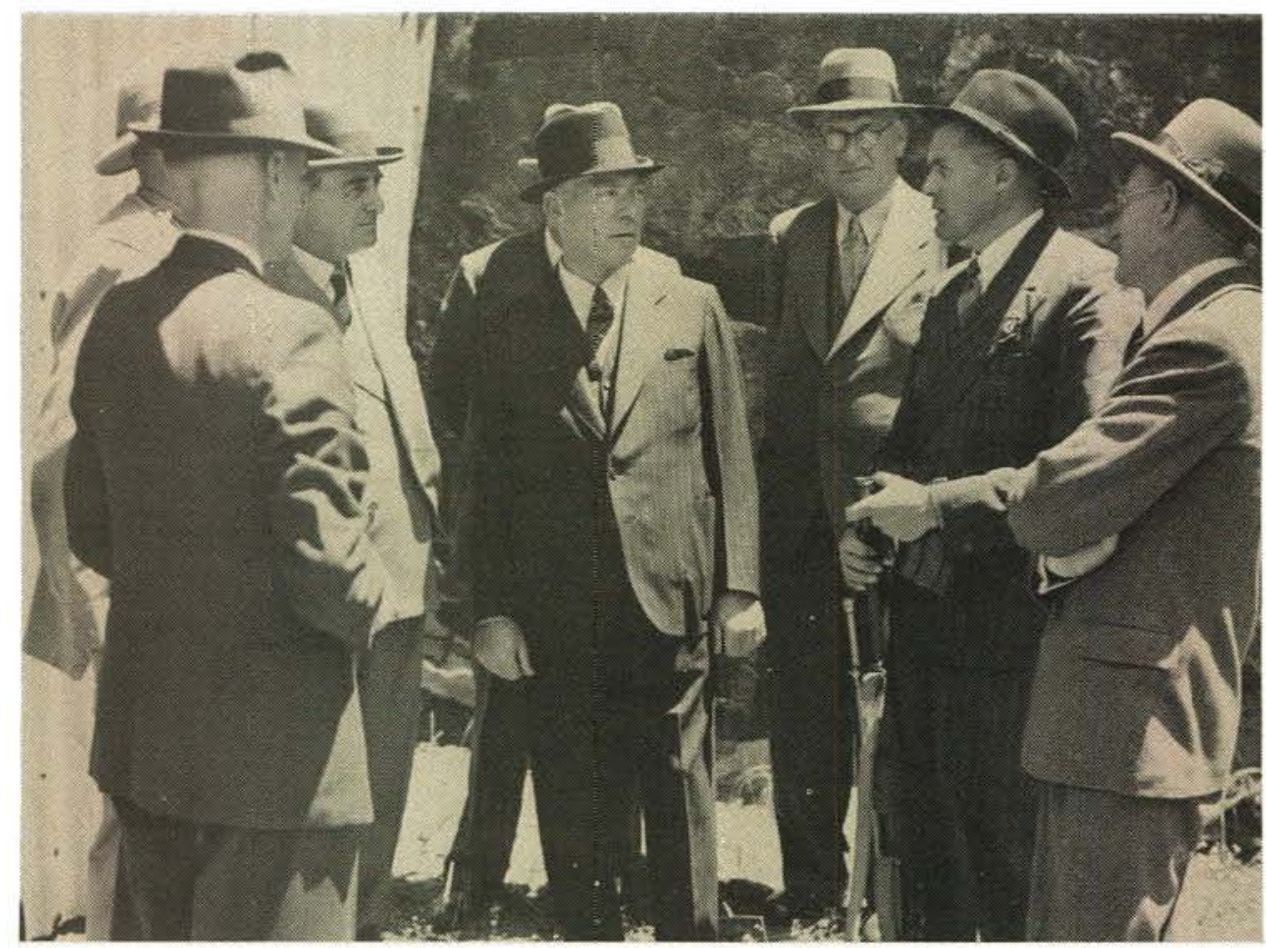

Dr H.J. van der Bijl, Director-General of War Supplies Centre with Mr H.J.R. Rieder (with rifle) after a demonstration of the latter's secret weapon, a .303 rifle with an automatic attachment outside the Castle in January 1941.
Dr H.J. van der Bijl, Direkteur-generaal van Oorlogsvoorrade (middel) in druk gesprek met mnr H.J.R. Rieder buite die Kasteel in Januarie 1941. Die geselskap het 'n demonstrasie van die nuutste geheime wapen, 'n .303 geweer met 'n outomatiese hegstuk, bygewoon. 


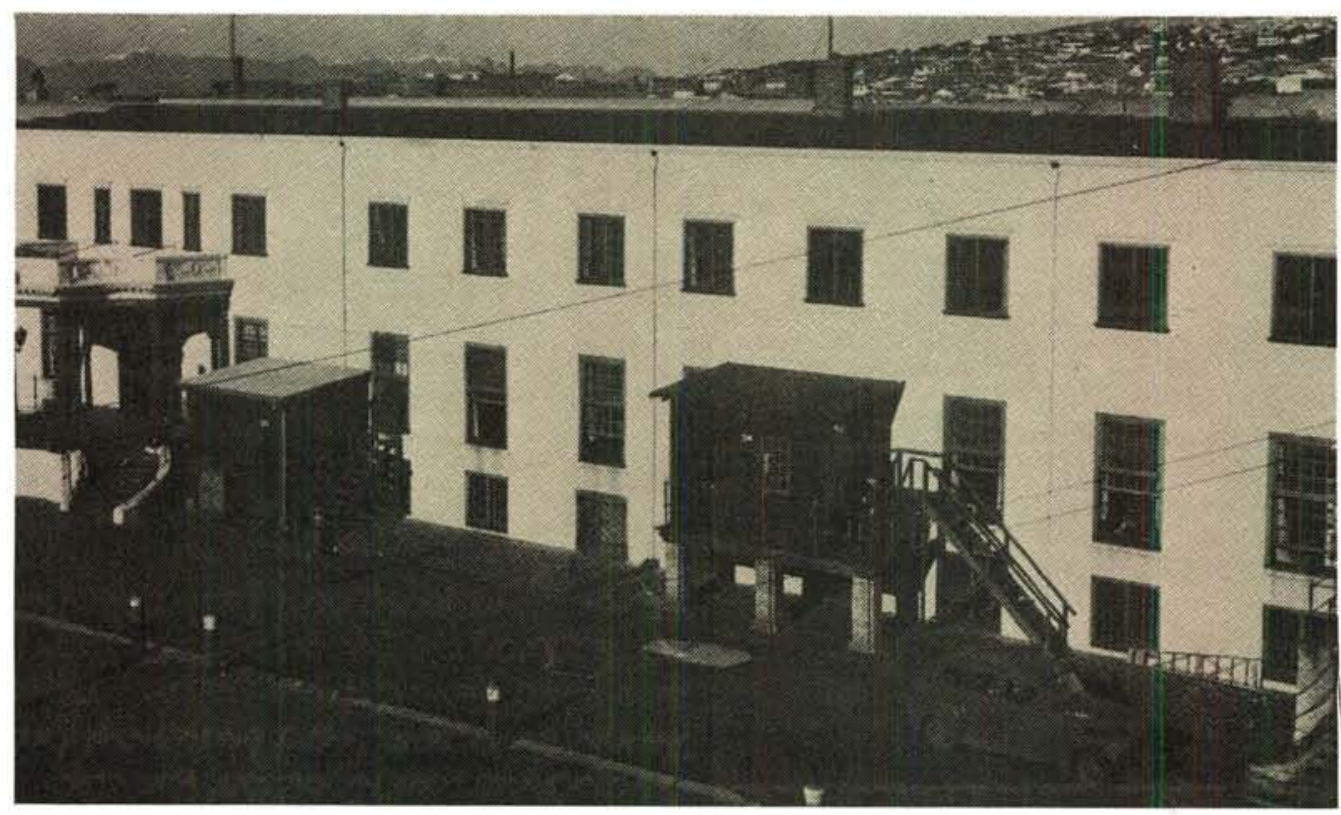

The former Government House during WW II. The room behind the "Nieuwe Kat" balcony was an Officer's Mess. Alongside it were the Special Signals Filter Room and the Combined Operations Room. Access to the latter was via the steps leading up to the temporary wooden enclosed verandah in the middle of the building.
Die eertydse Goewerneurswoning gedurende WO II. Die kamer agter die "Nieuwe Kat" balkon was 'n offisiersmenasie. Langsaan dit was die Spesiale Seinkamer en die Gesamentlike Operasiekamer. Toegang tot dié kamers kon verkry word via die trap wat na die tydelike houtstoep in die middel van die gebou gelei het.

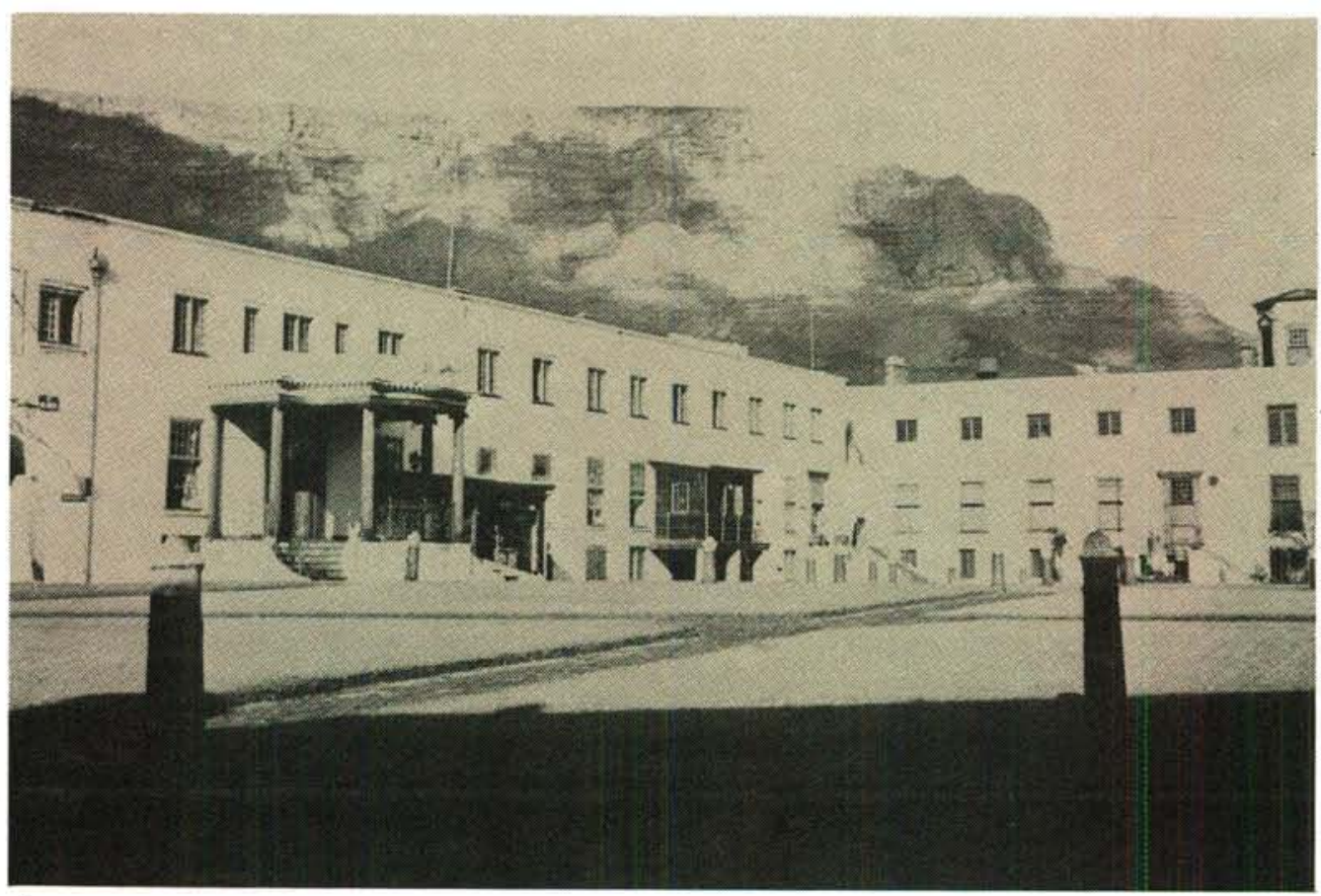

Close up of the exterior of the Combined Operations Room during WW II. (Notice the snow capped mountains and winter uniforms.)
Die buitekant van die Gesamentlike Operasieskamer gedurende die Tweede Wêreldoorlog. (Sien die sneeubedekte berge en winteruniforms). 


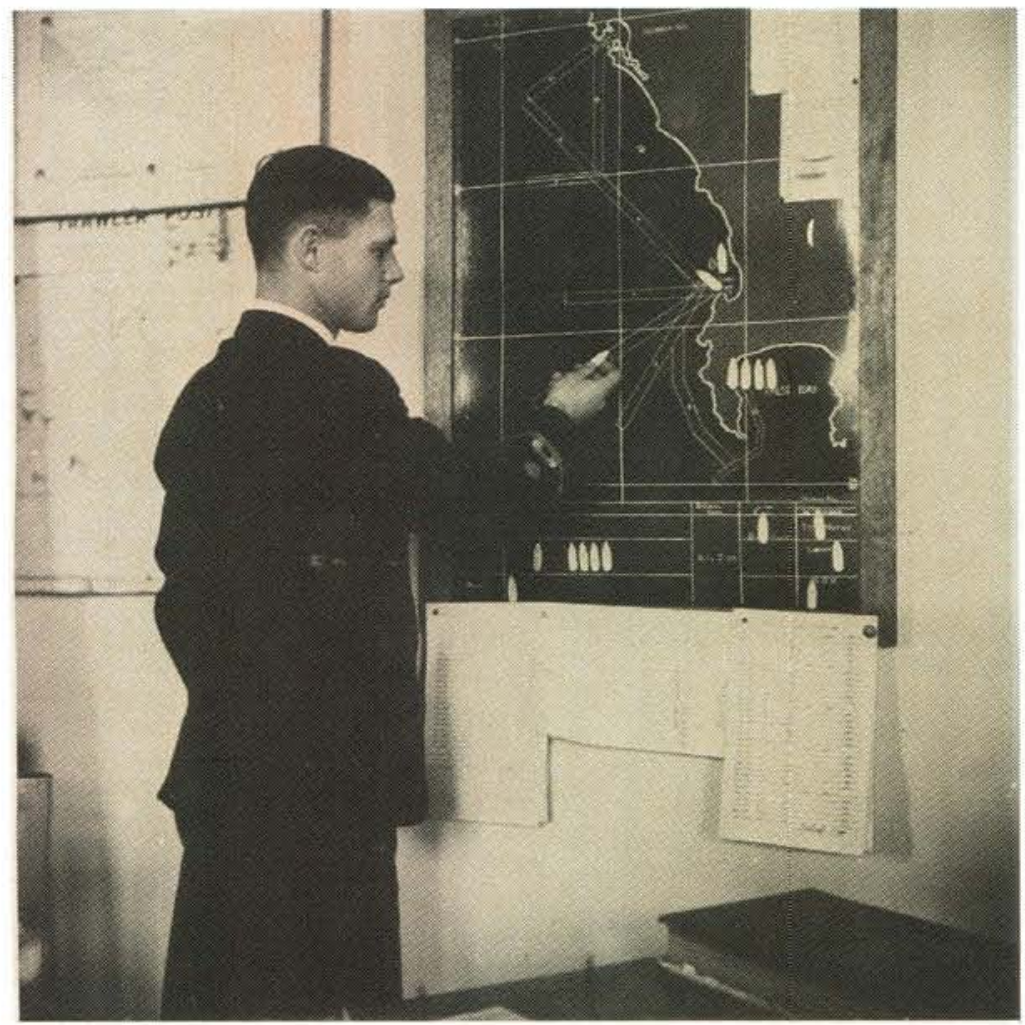

Sub Lieutenant J.H.F. Lilley was one of the SA Naval Forces officers who manned the Castle's Combined Operations Room.

Onder-luitenant J.H.F. Lilley was een van die $S A$ Seemagoffisiere wat die Kasteel se gesamentlike operasiekamer beman het.

Details of the departures and arrivals of ships are updated.

Besonderhede ten opsigte van die aankoms en vertrek van skepe word op datum gehou.

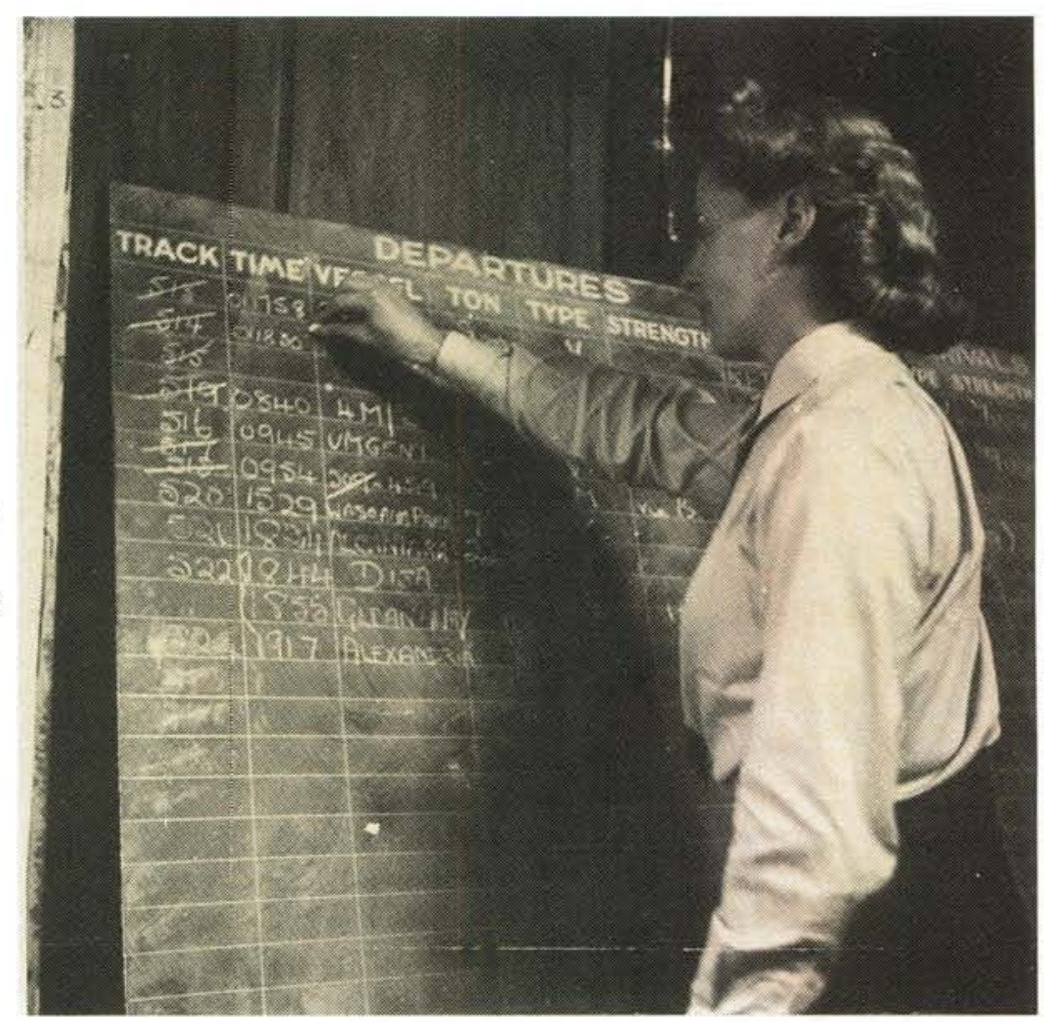




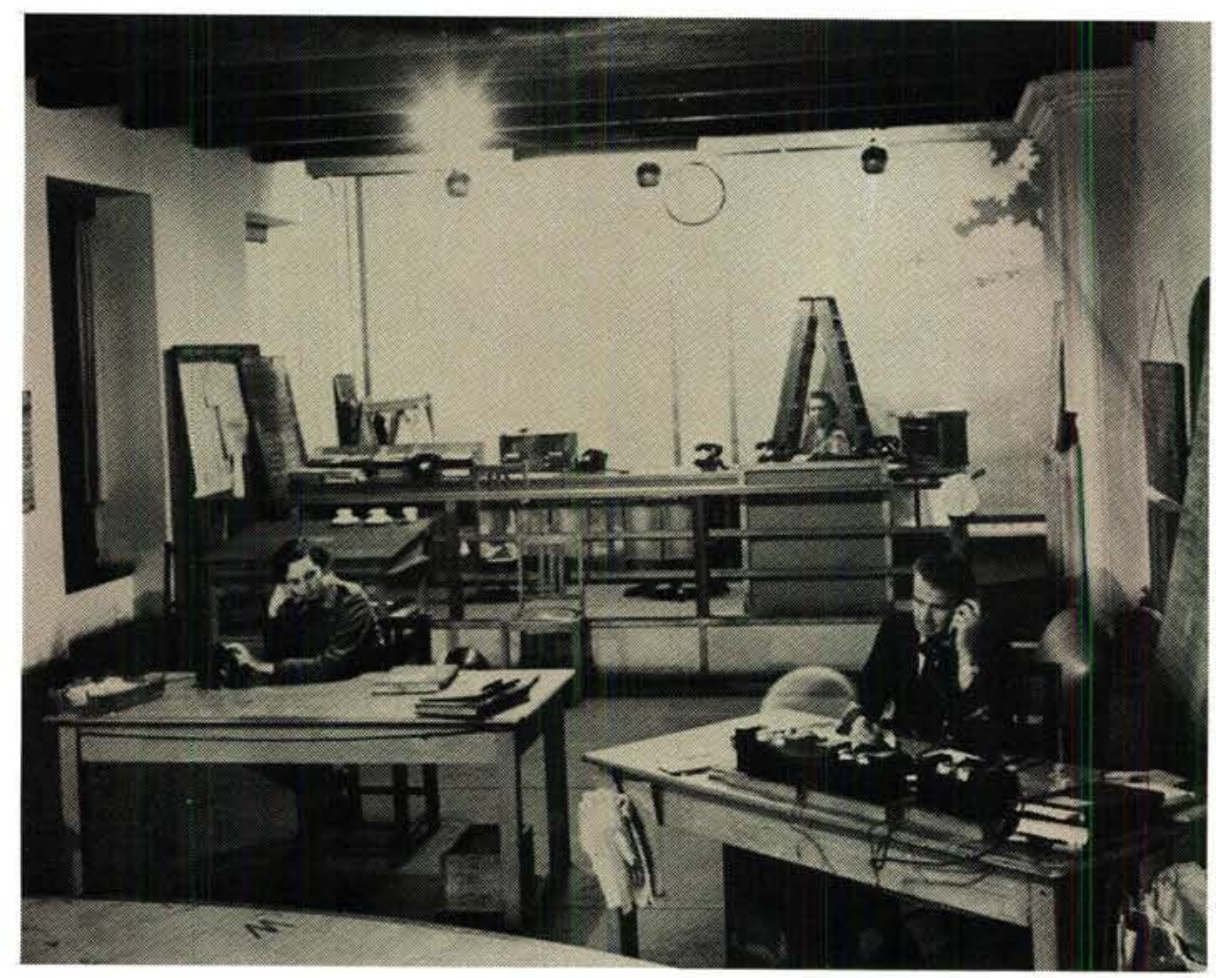

The Combined Operations Room in the Castle in 1945.

Die gesamentlike operasiekamer in die Kasteel in 1945.

Combined Operations personnel on duty: Lieutenant P. Minty, centre, and Privates M. Henderson and T. Imrie.

Gesamentlike operasiepersoneel op diens: luitenant P. Minty, middel, en weermanne $M$. Henderson en T. Imrie.

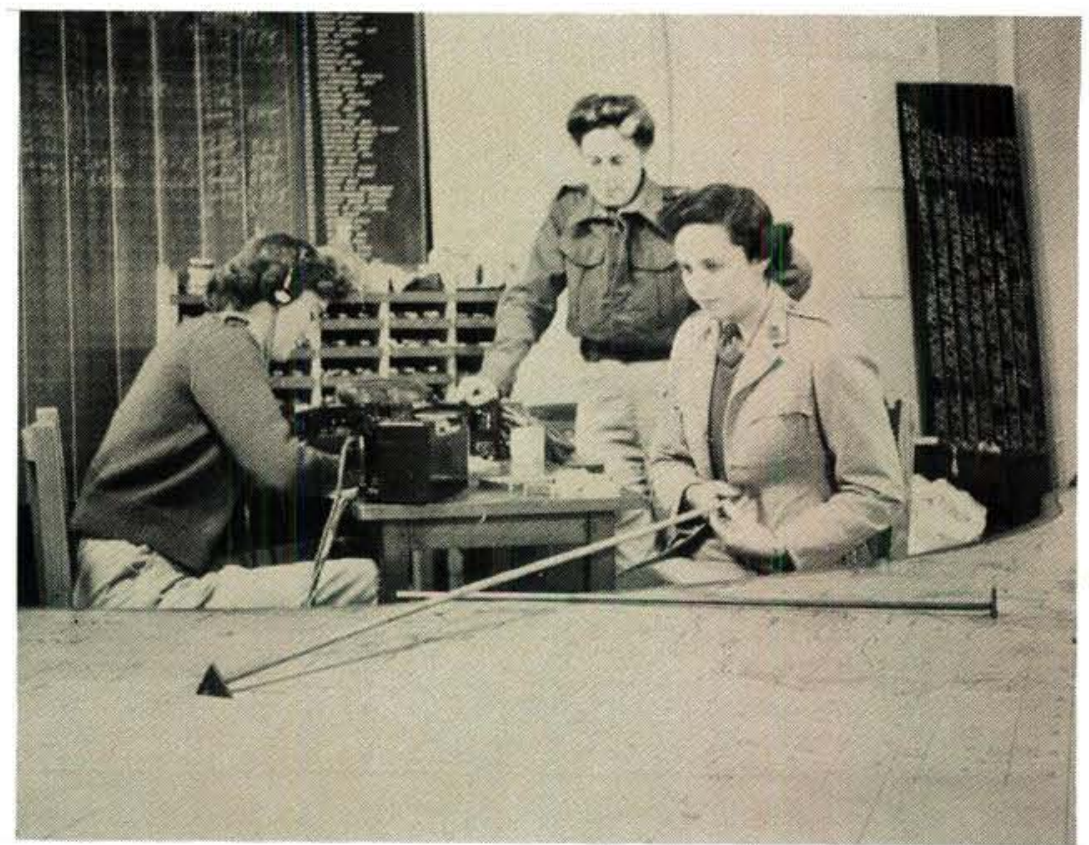




\section{5}

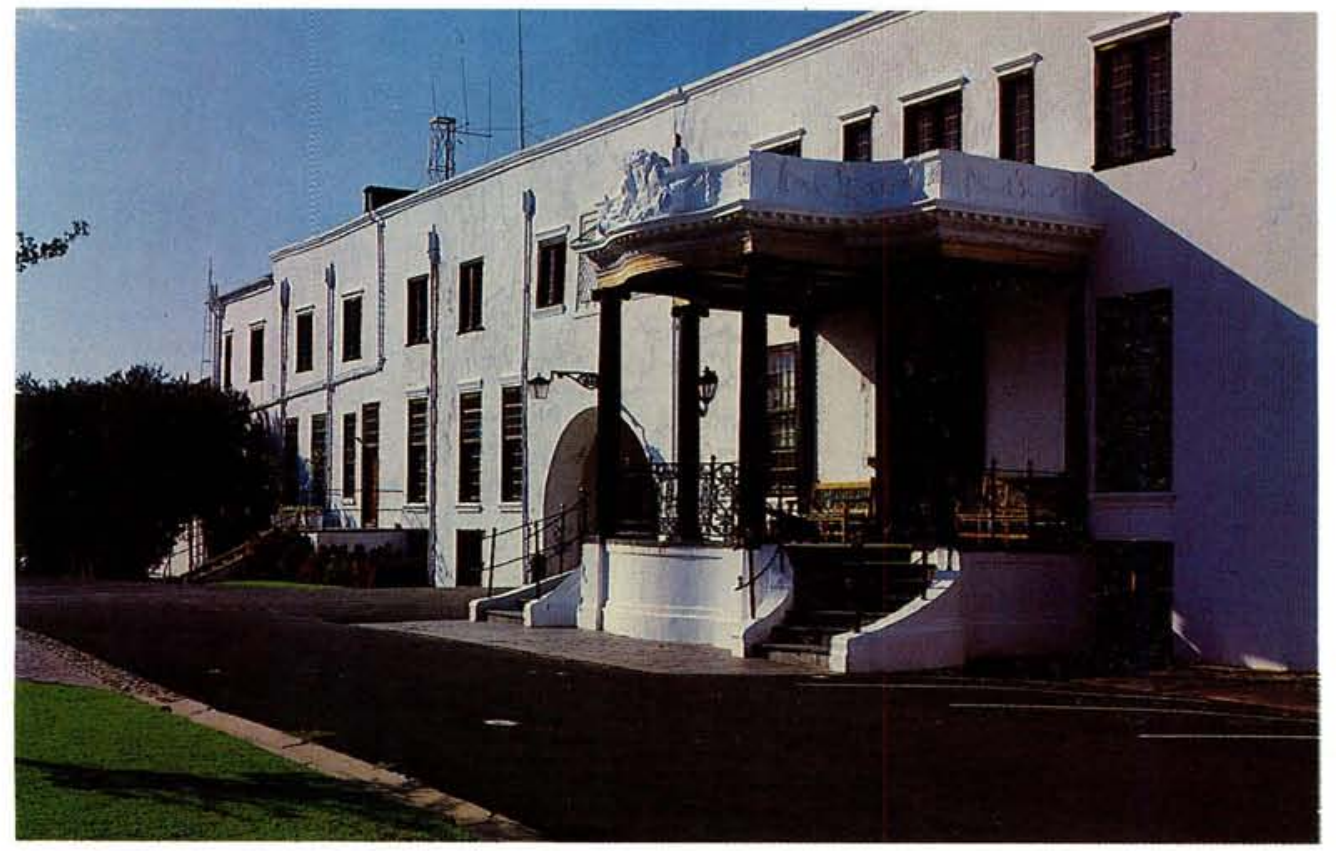

The "Nieuwe Kat" Balcony

Die "Nieuwe Kat" balkon

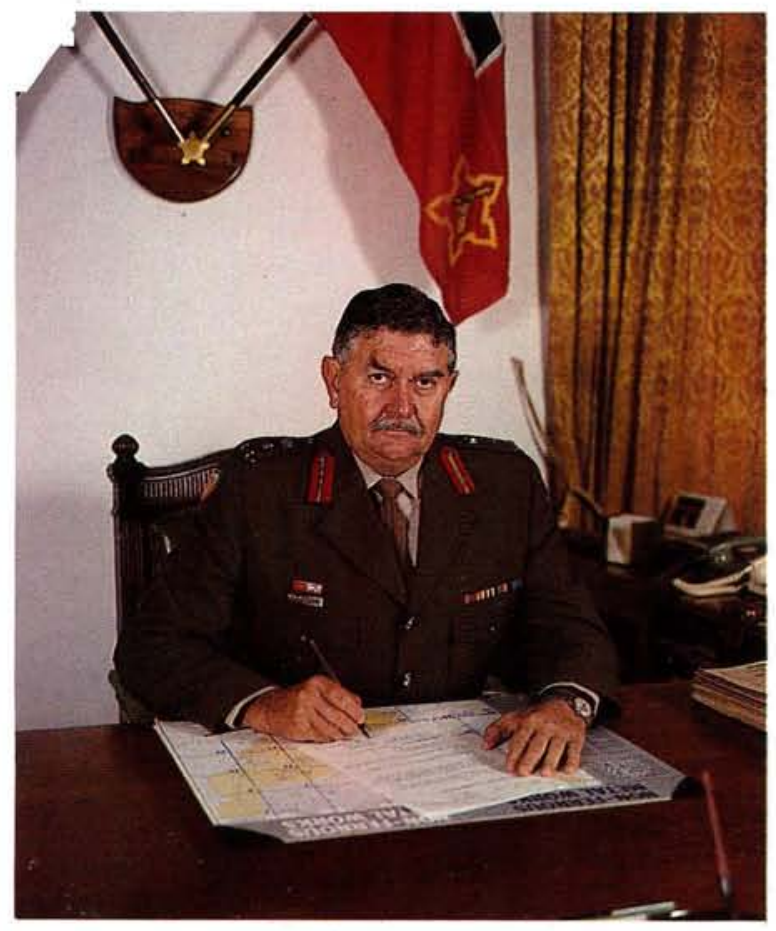

Brig Y. de Bruyn, Officer Commanding Western Province Command since 1 February 1985.

Brig Y. de Bruyn, bevelvoerder van die Kommandement Westelike Provinsie sedert 1 Februarie 1985.

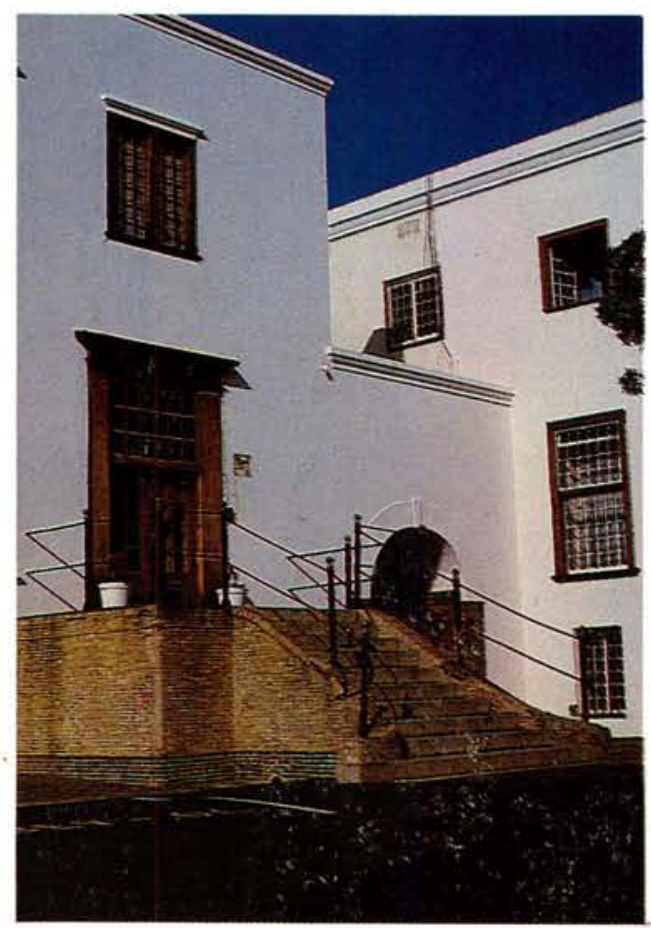

One of the entrances to the former Government House at the Castle.

Een van die ingange na die vroeëre Goewermentshuis by die Kasteel. 


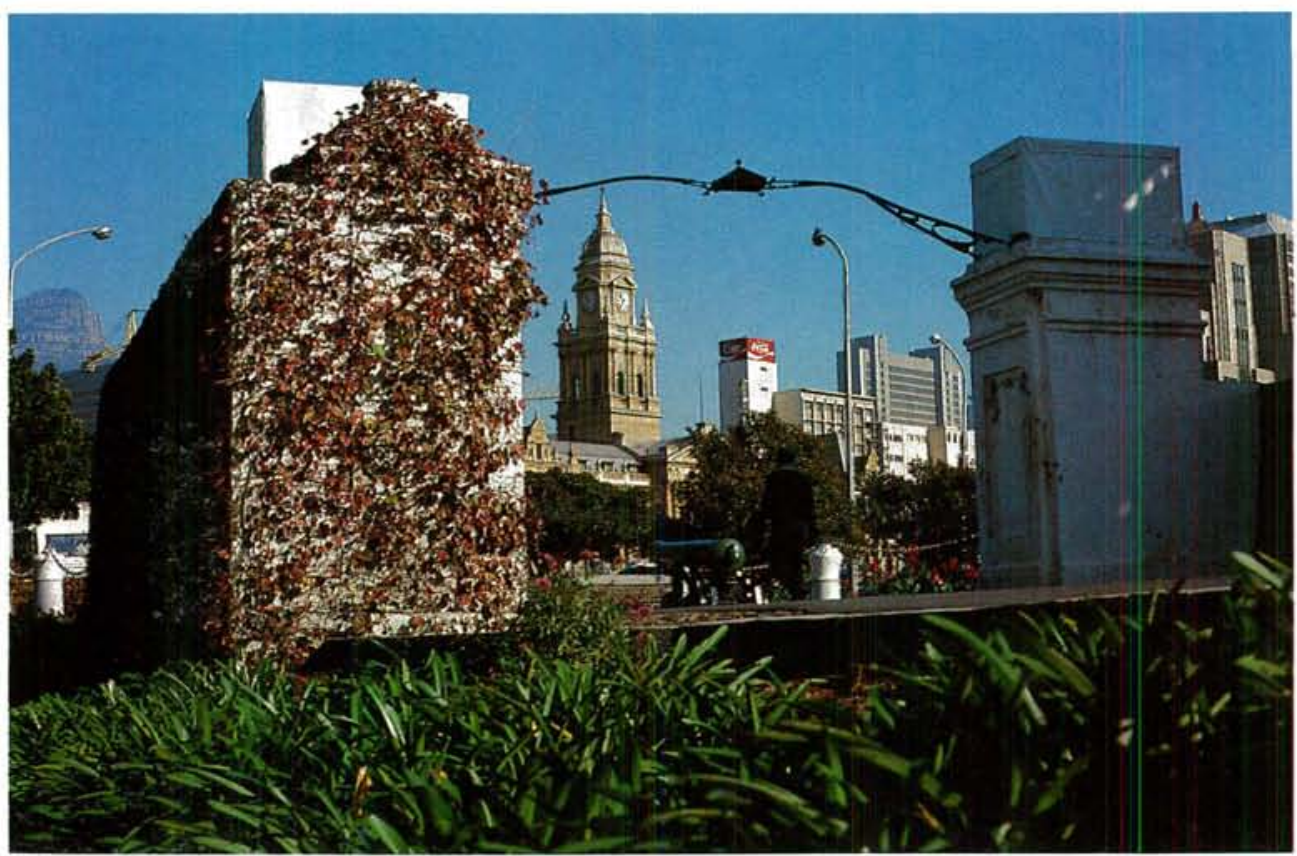

Entrance gates June 1985. On the background the old City Hall of Cape Town can be seen.

Ingangshekke Junie 1985. In die agtergrond is die ou stadsaal van Kaapstad.

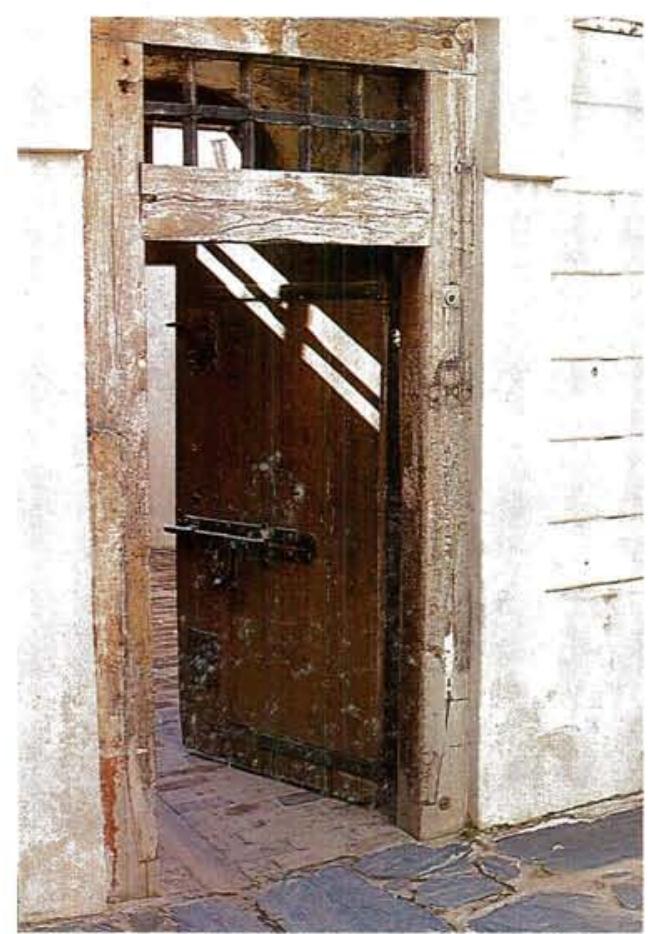

Entrance to the cells in Katzenellenbogen Bastion.

Ingang tot die selle in Katzenellenbogen bolwerk.

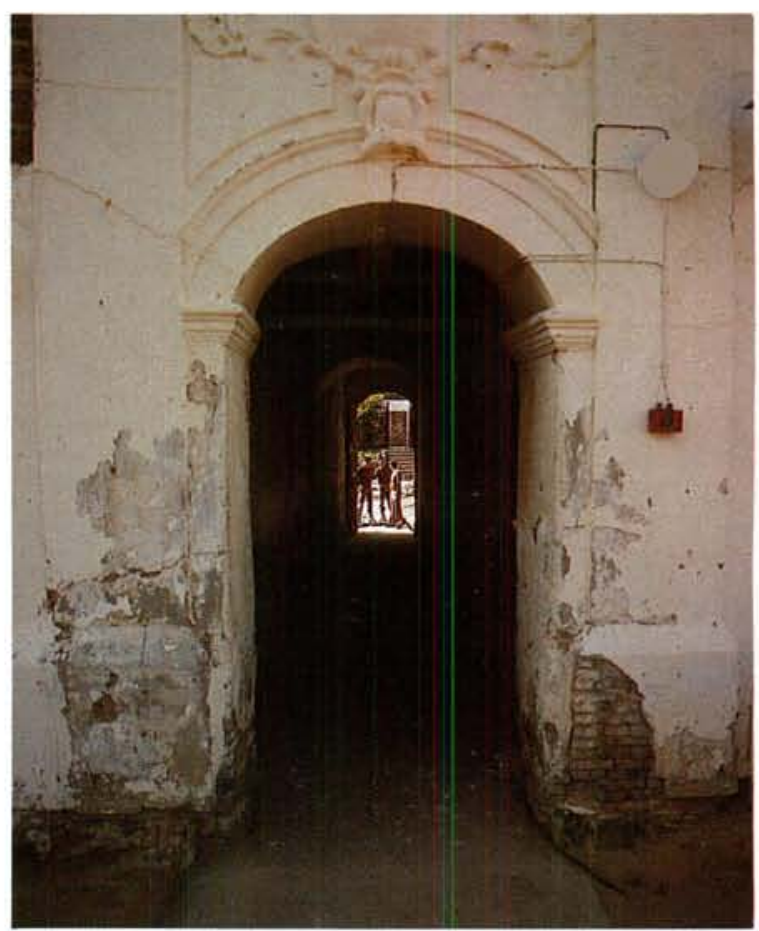

The Sally Port

Die Uitvalspoort 


\section{Restoration in the Inner Courtyard Binneplein}
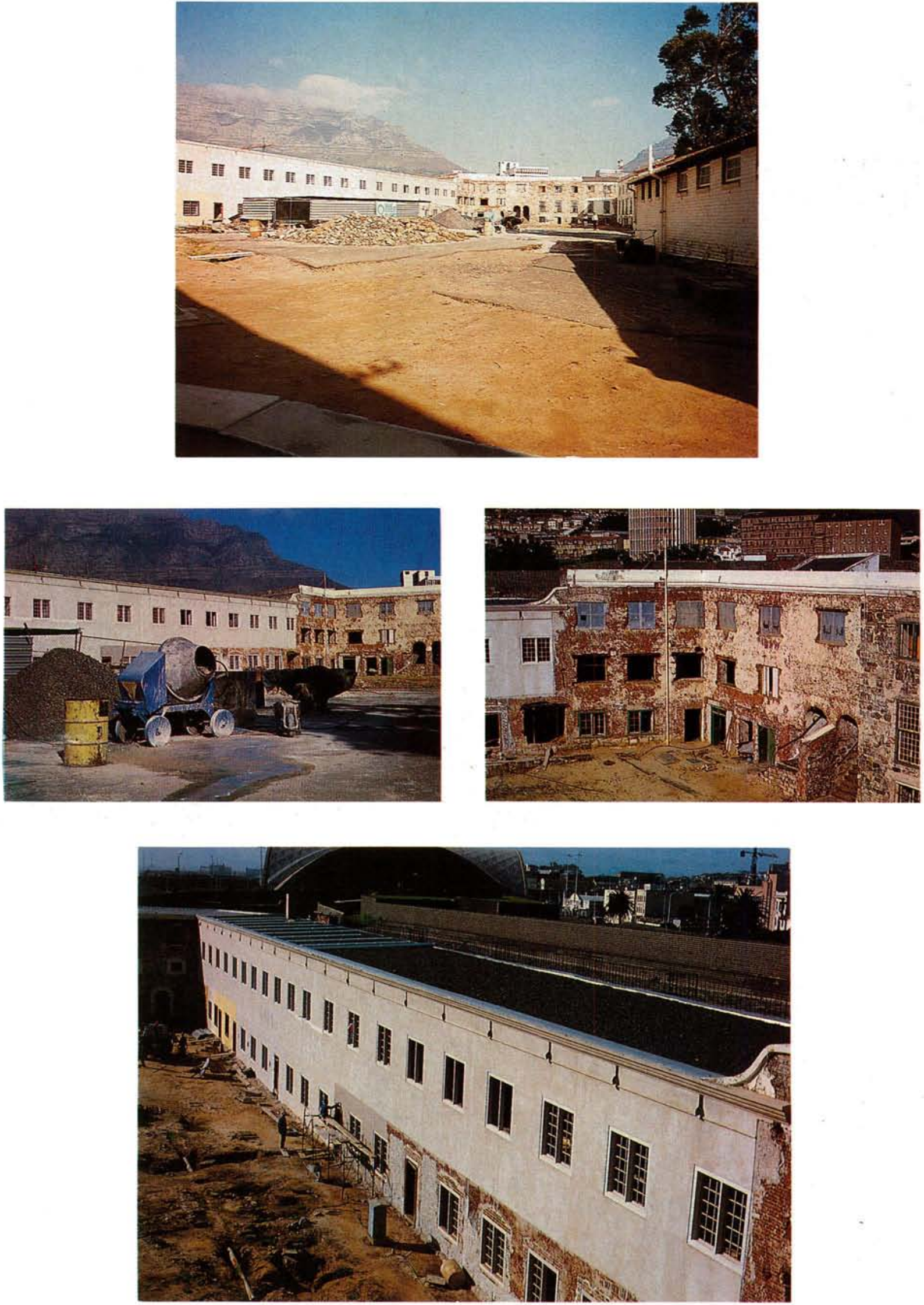


\section{Outside the Castle}

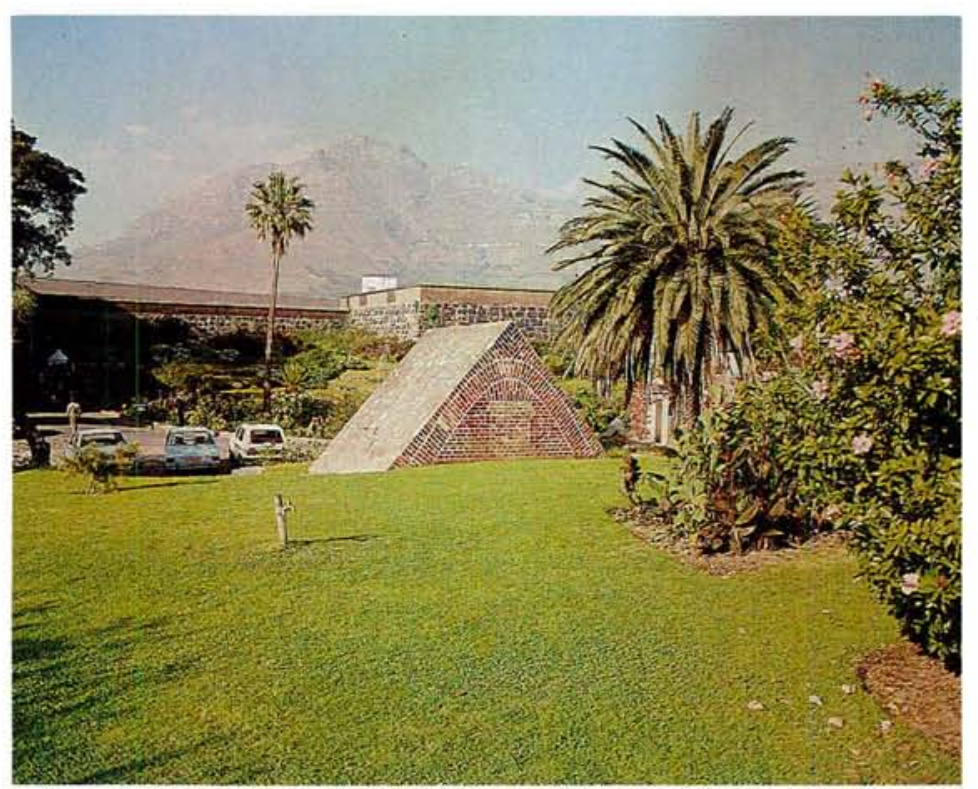

\section{Buite die Kasteel}

The powder magazine on the Ravelin outside the Castle.

Die kruithuis op die ravelyn buite die Kasteel.
The National Flag on Leerdam Bastion. In the background is Table Mountain.

Die Landsvlag wapper op Leerdam-bolwerk. In die agtergrond is Tafelberg.
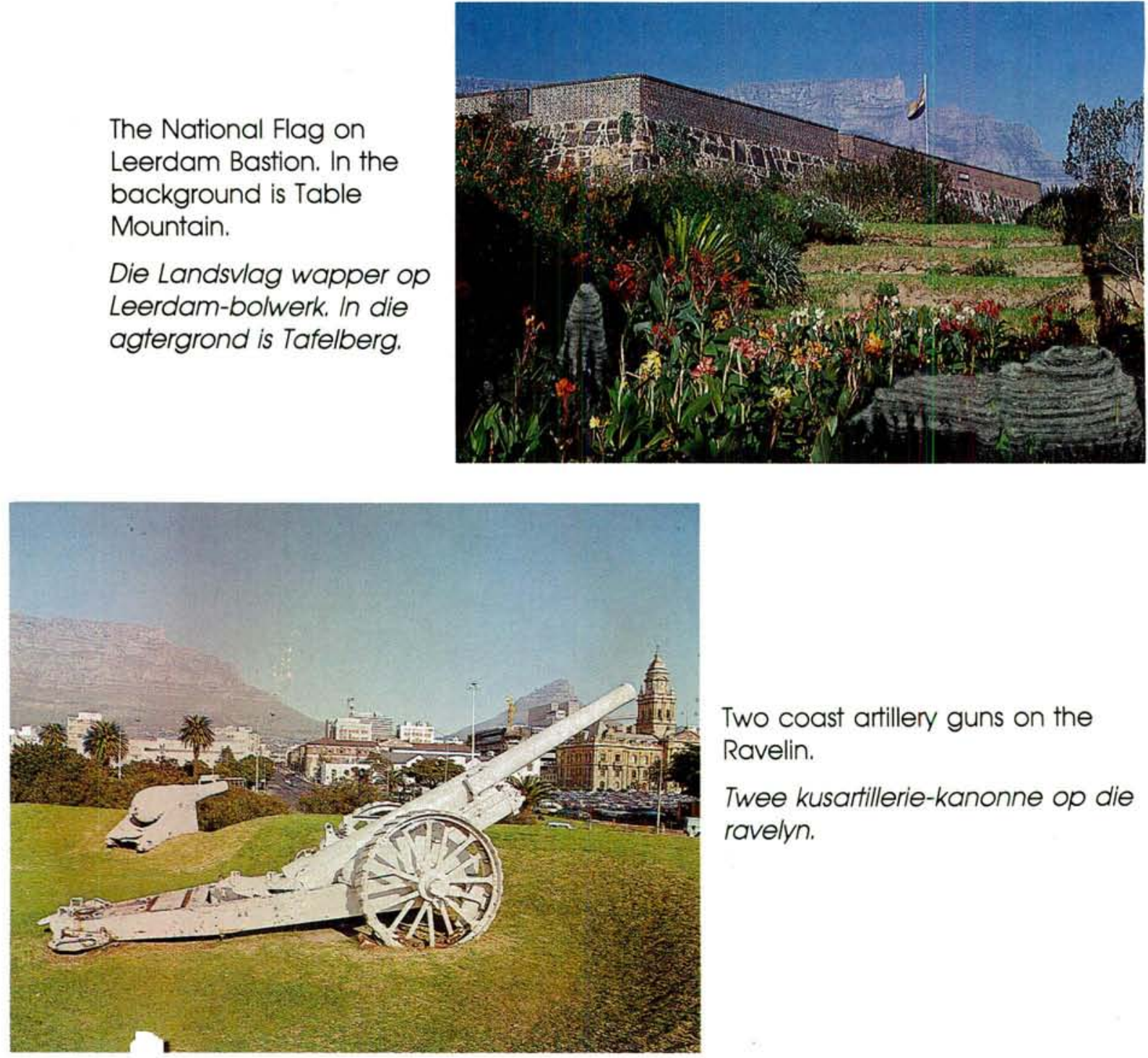

Two coast artillery guns on the Ravelin.

Twee kusartillerie-kanonne op die ravelyn. 


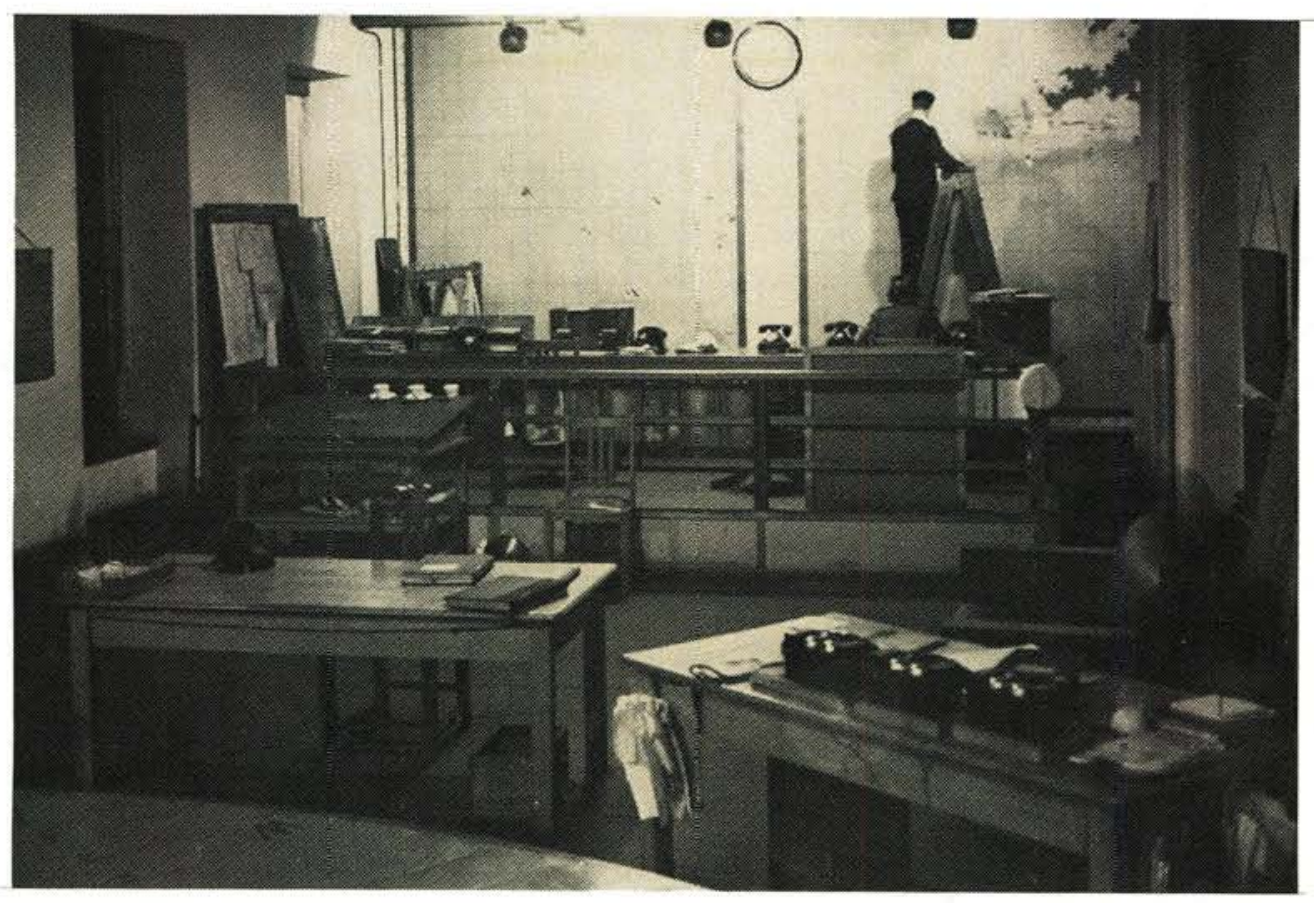

The Castle's Operations Room during the Second World War.
Die operasiekamer gedurende die Tweede Wêreldoorlog.
" $G$ " Section of the Combined Operations Room at the Castle during the Second World War. Those in the lower photograph include Sgt F.V. Watson (left) and Sub Lt J.H.F. Lilley.
Die " $G$ " seksie van die Gesamentlike Operasiekamer by die Kasteel gedurende WO II. Op die onderste foto sit sers F.V. Watson (links) en o It J.H.F. Lilley.

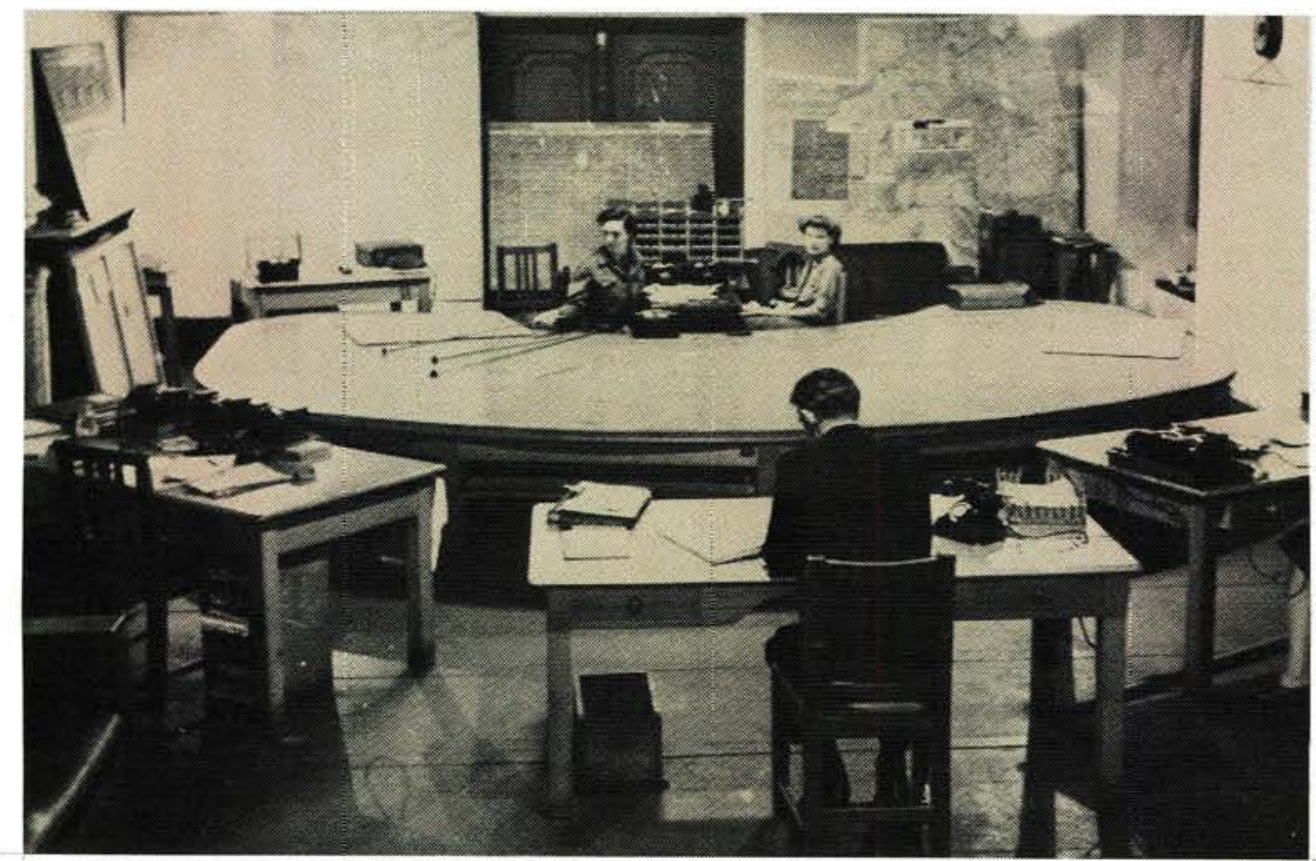




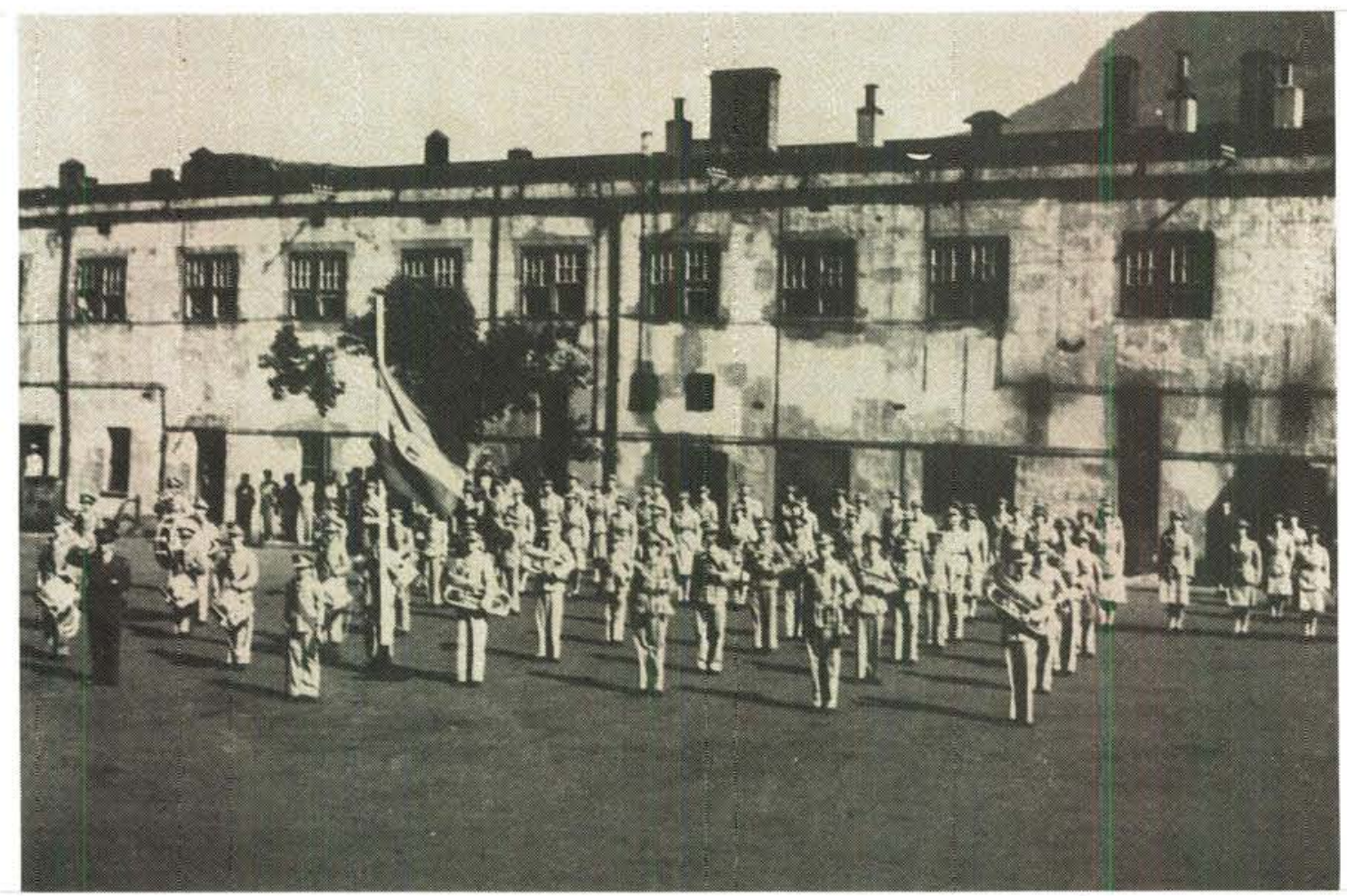

The Young South African League band, official band to the 22nd SA Coast Defence Corps and the Civilian Protective Services on parade at the Women's Auxiliary Army Services 4th Birthday Retreat Ceremony.
Die Orkes van die Vereniging Jong SuidAfrika, wat die amptelike orkes van $22 e$ Bataljon SA Kusverdedigingskorps en die Burgerlike Beskermingsdiens was, tree op tydens die vlagstrykingseremonie van die Vroue Hulpleërdiens se vierde verjaardag in Junie 1944.

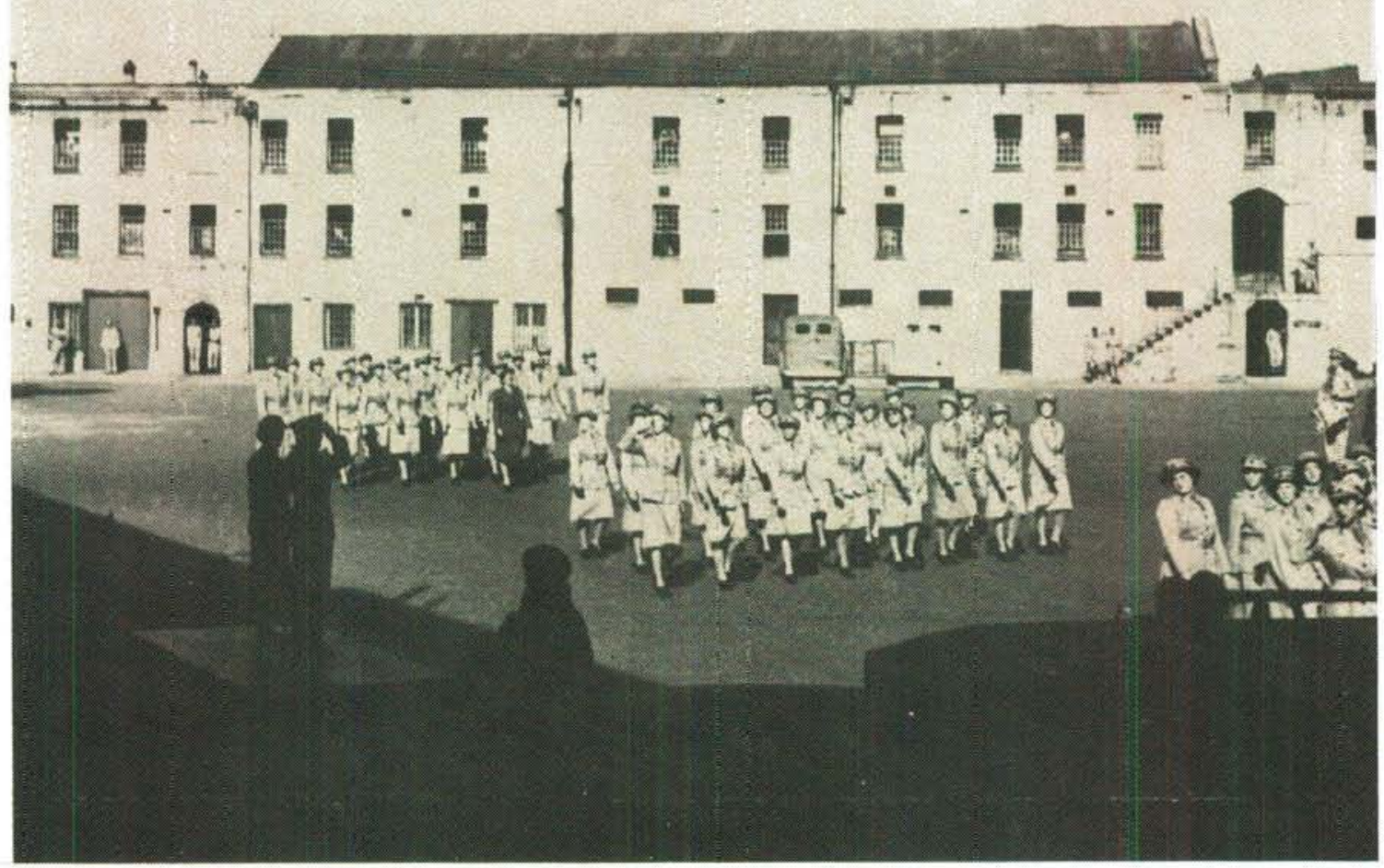




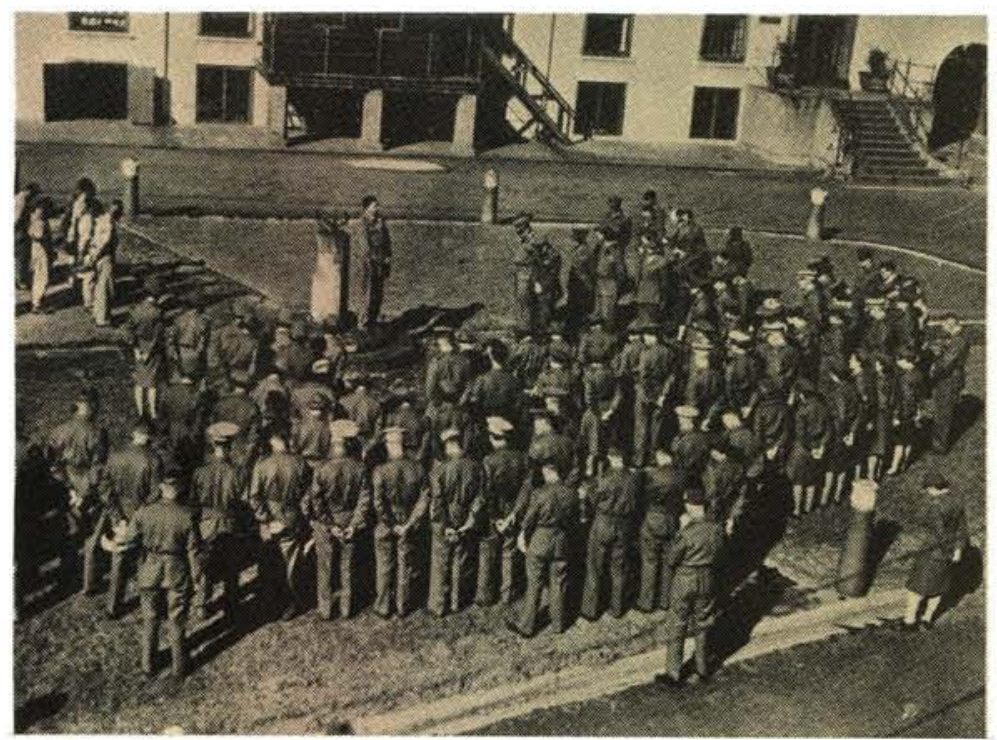

A church parade in the outer courtyard during the Second World War.

\section{'n Kerkparade in die buitenste binnehof} gedurende die Tweede Wêreldoorlog.

On VE day (Victory in Europe) 8 May 1945, the Fortress Commander, Brig C.E. Borain, DSO, MC, VD, ED, announced the thrilling news to the garrison from the "Nieuwe Kat" balcony. News of the Armistice on 11 November 1918 and of V-J day (Victory over Japan) on 2 September

1945 were announced in the same way to the paraded troops.

Op 8 Mei 1945, kondig die Fort Bevelvoerder, brig C.E. Borain, DSO, $M C, V D, E D$, vanaf die "Nieuwe Kat" balkon die vredestyding in Europa aan. Nuus van die wapenstilstand op 11 November 1918 en van die oorwinning oor Japan op 2 September 1945 is op dieselfde wyse aan die soldate oorgedra.

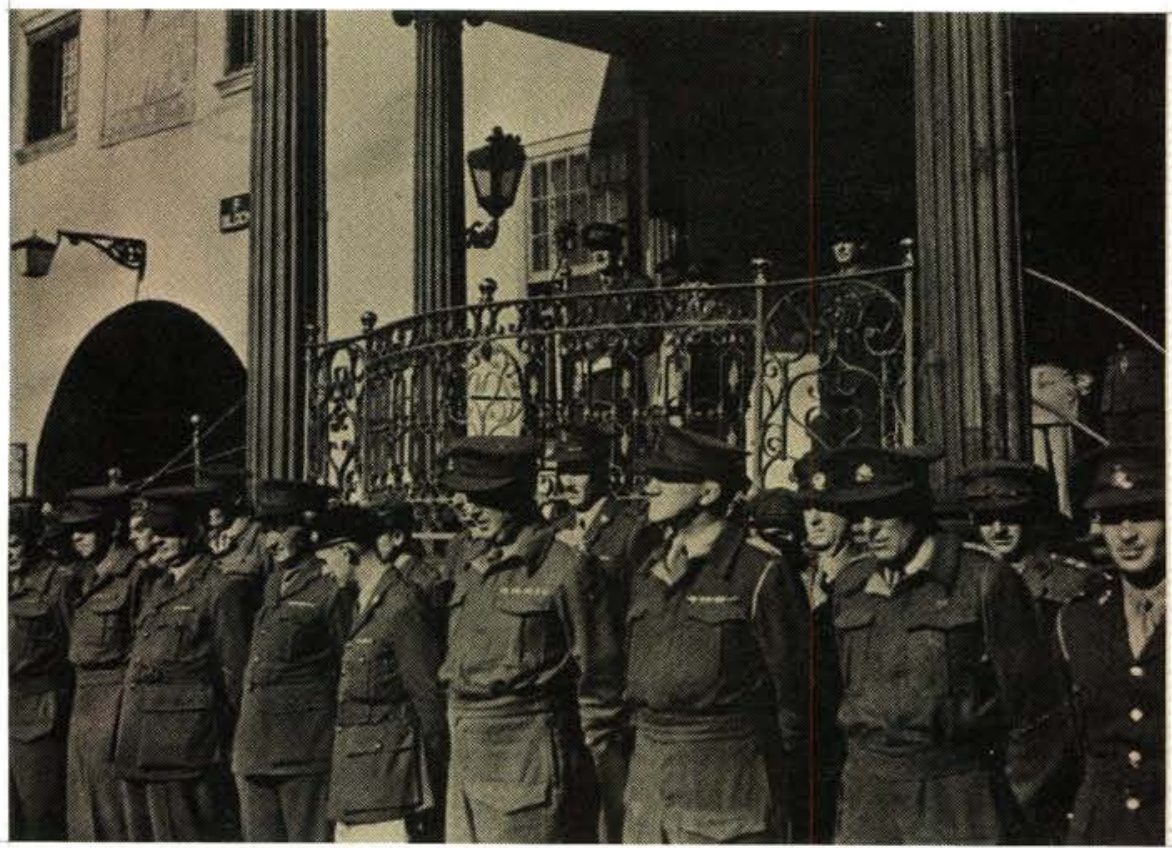



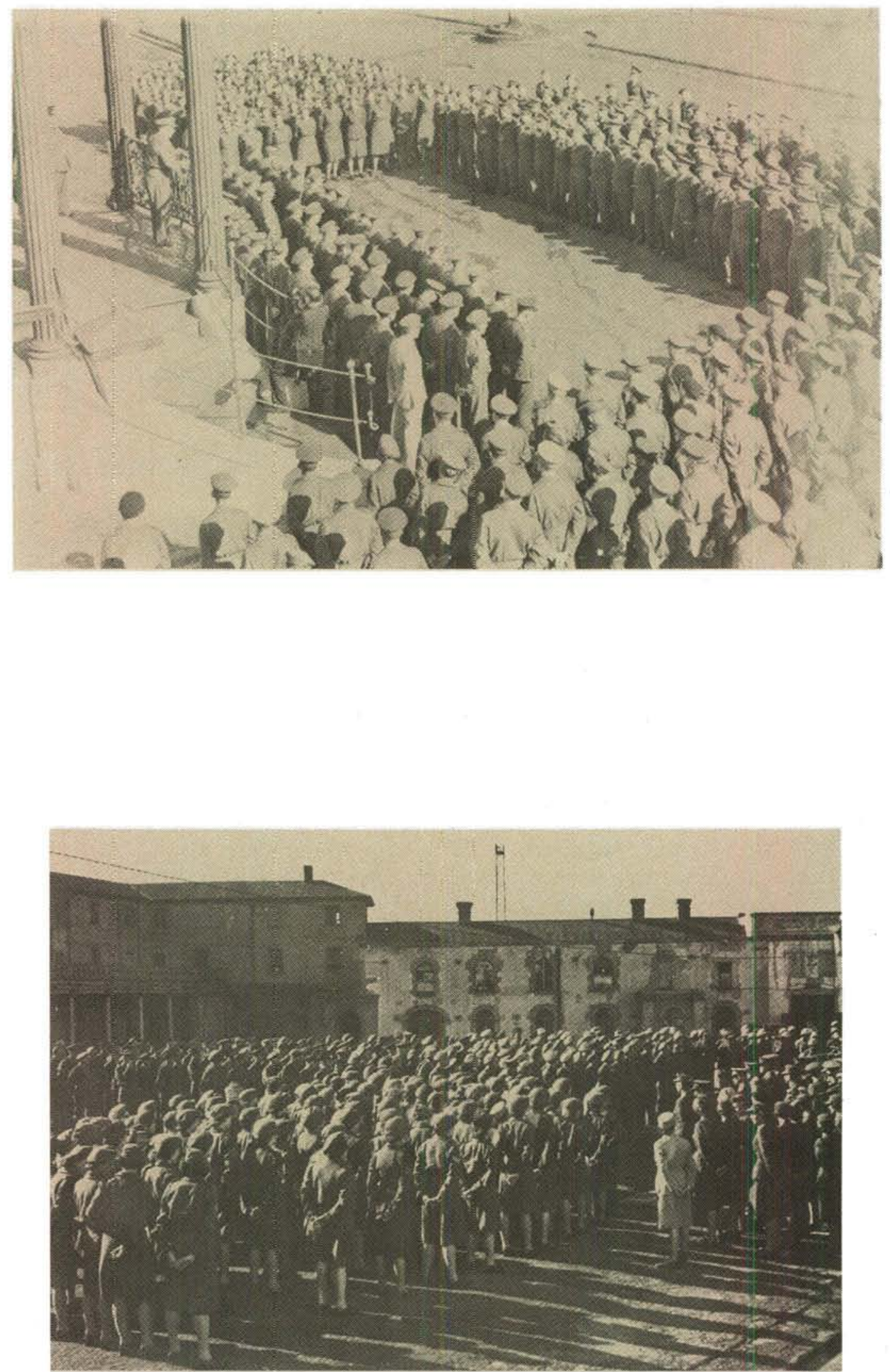

The Fortress Commander, Brig B.F. Armstrong, DSO announces the end of the Second World War on 14 August 1945.

Die Fort Bevelvoerder, brig B.F. Armstrong, DSO kondig die einde van die Tweede Wêreldoorlog aan op 14 Augustus 1945. 


\section{The Castle as fortress Die Kasteel as vesting}

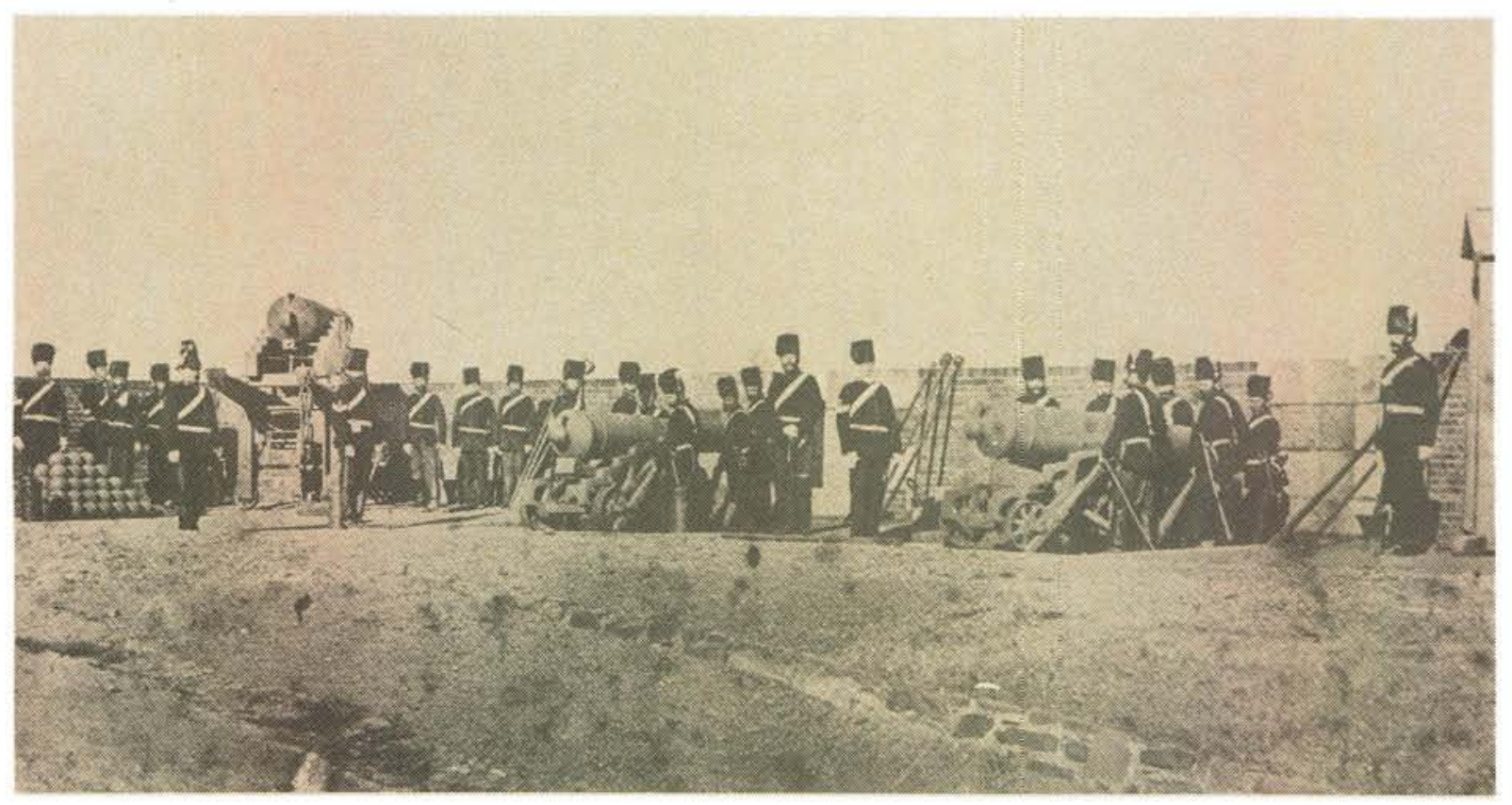

The Cape Field Artillery manning the guns of the Imhoff Battery on the Seaward side of the Castle.

Die Cape Field Artillery beman die kanonne van die Imhoff Battery aan die seewaartse kant van die Kasteel.

One of the castle's original cannons.

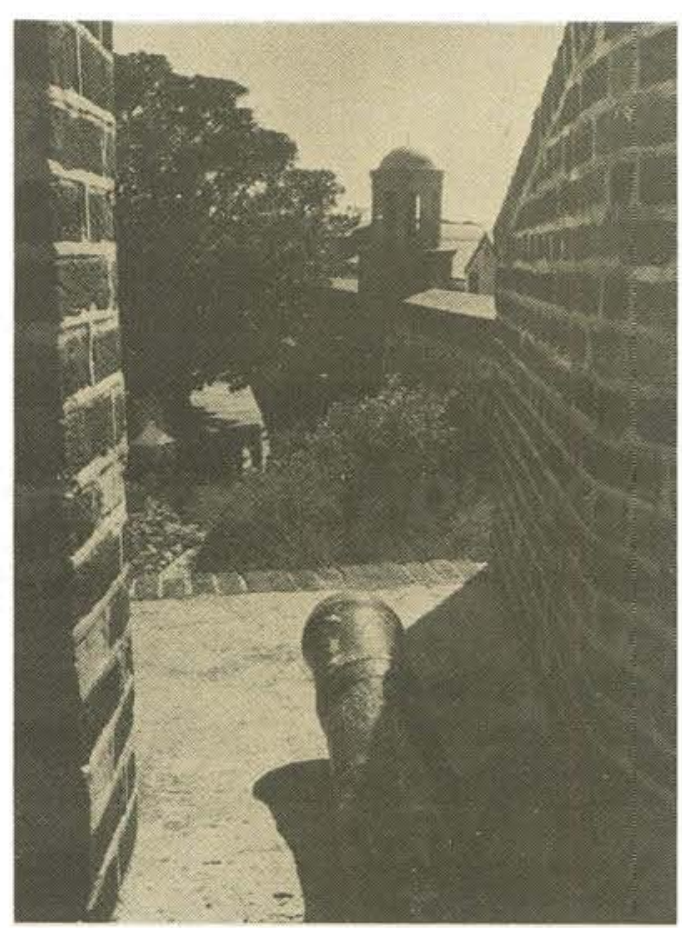

Een van die Kasteel se oorspronklike kanonne. 


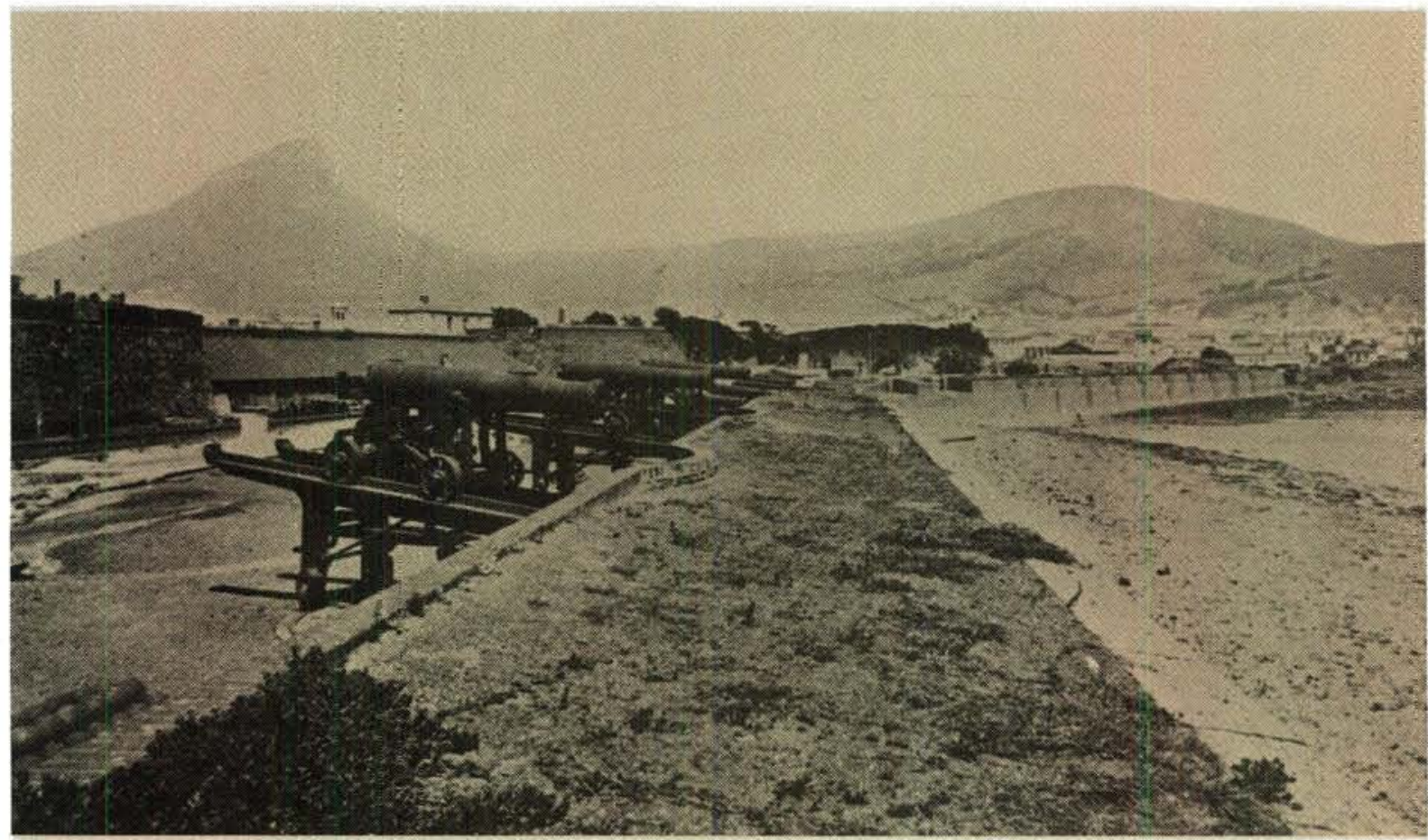

The Imhoff Battery was built on the instructions of Baron von Imhoff, Governor-General of the Dutch East Indies, to protect the seaward side of the Castle. The foundation stone was laid on 23 November, 1744. It was originally armed with 48 heavy guns and several mortars. It was later used as a saluting battery. In 1896 it was demolished to provide ground for railway expansion.

Die Imhoff Battery is gebou in opdrag van Baron von Imhoff, Goewerneur-Generaal van die HOIK om die seewaartse kant van die Kasteel te beskerm. Die hoeksteen is op 23 November 1744 gelê. Dit was oorspronklik bewapen met 48 swaar kanonne en verskeie mortiere. Dit is later gebruik as 'n salueer battery. Dit is in 1896 gesloop om plek te maak vir spoorweguitbreidings.

In February 1952 the Fort Knokke guns which had stood in the moat of the Castle for many years were moored to the Ravelin outside the main entrance. This 7-inch $6 \frac{1}{2}$ tons Rifled Muzzle Loading Gun MK I is dated 1866. Its range was 3170 yards.

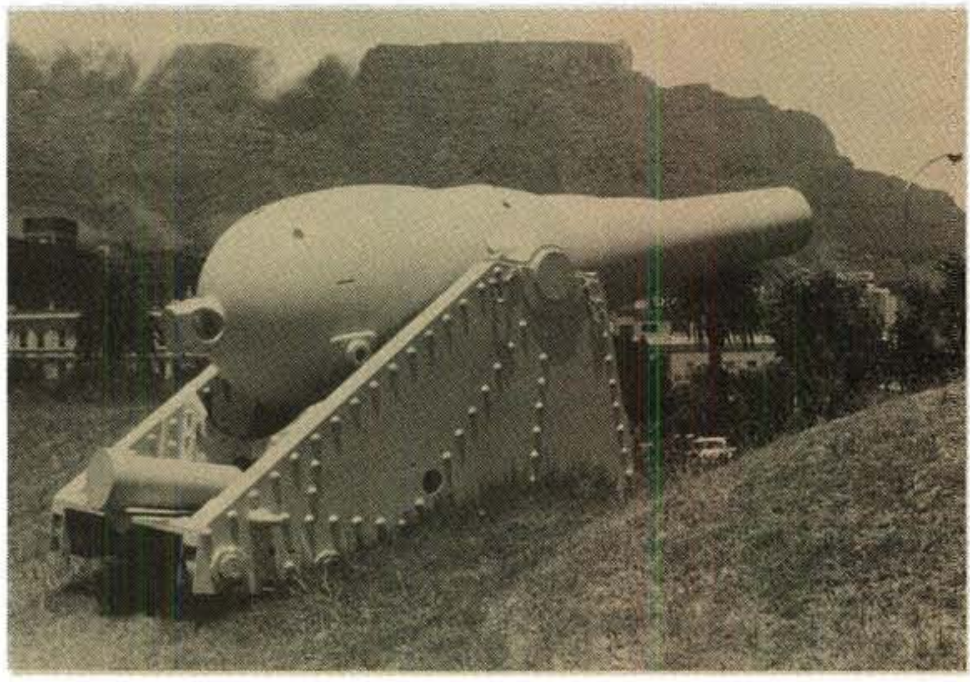

Die Fort Knokke se kanonne wat jare lank in die Kasteel se grag gestaan het, is in Februarie 1952 na die ravelyn buite die hoofingang verskuif. Hierdie 7-duim 6 $\frac{1}{2}$ ton Voorlaaierkanon MK I is in 1866 gemaak. Die kanon se skootafstand was 3170 tree. 


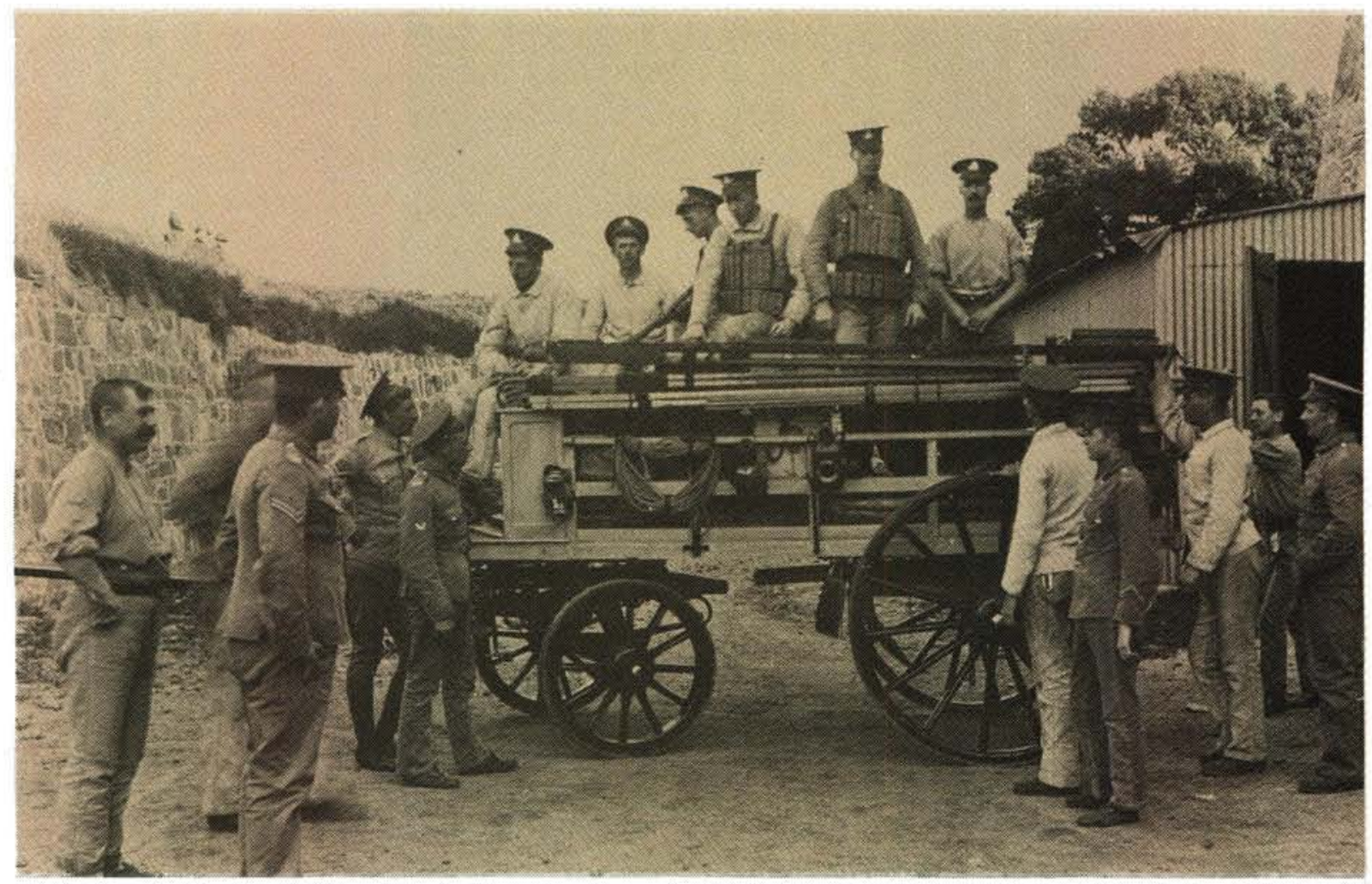

For many years the Royal Garrison Artillery was responsible for the rocket life-saving apparatus. Number 1 Company was based at the Castle and practices were held every month. On this photograph Royal Garrison Artillery gunners can be seen with the wagon beneath one of the bastions of the Castle.

Vir baie jare was die Royal Garrison Artillery verantwoordelik vir die vuurpyl lewensreddersapparaat. Nommer 1 Kompanie se basis was by die Kasteel en oefeninge is elke maand gehou. Op hierdie foto kan Royal Garrison Antillery Kanoniers gesien word met die wa, onder een van die bastions van die Kasteel.

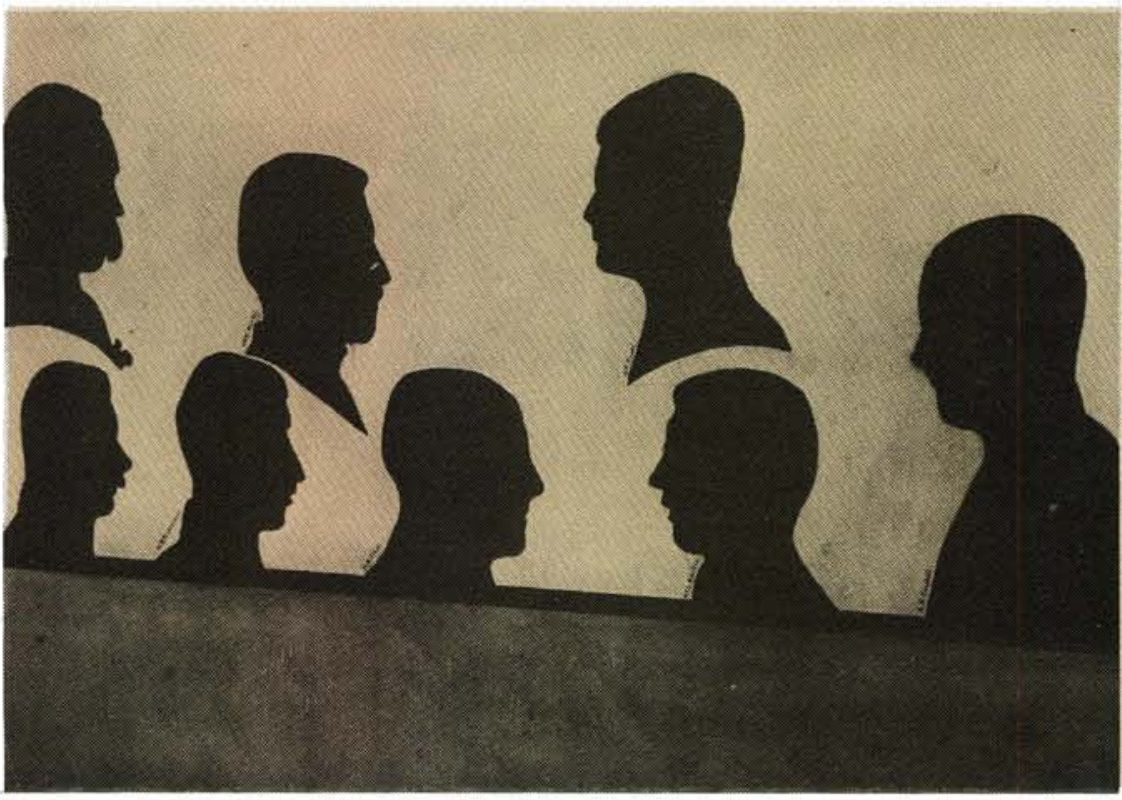

These silhouettes of coast gunner officers decorate the walls of the house in Buren bastion.

Hierdie silhouette van kusartillerie-offisiere versier die mure van die huis in Buren bastion. 


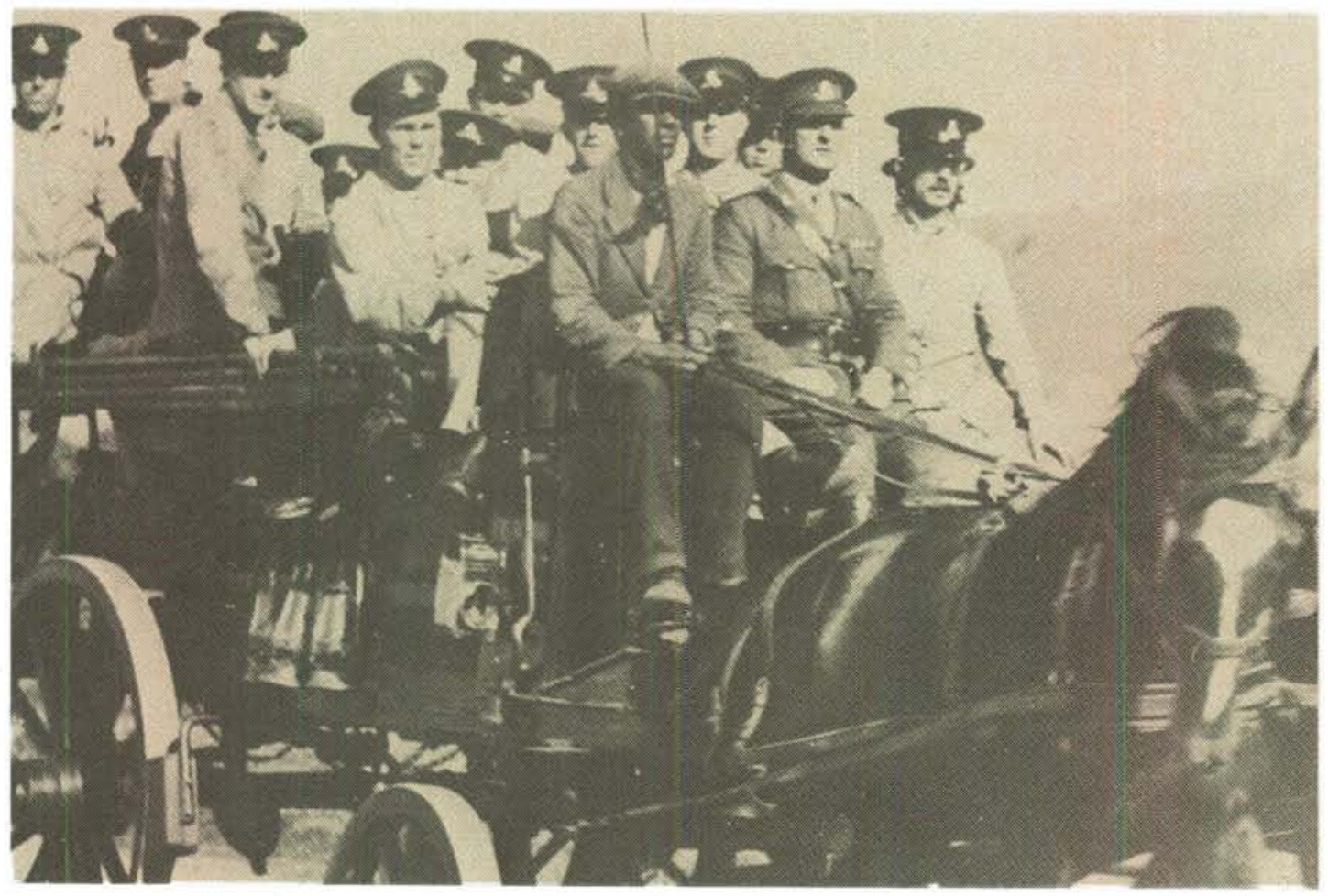

After the departure of the British Garrison South Africa established its own Permanent Garrison Artillery to man its fixed defences. Alongside the driver on the Castle's wagon is Master Gunner Torr.

Na die Britse besettingsmag se onttrekking het Suid-Afrika 'n eie Permanente Artillerie garnisoen gestig om die Kasteel te verdedig. Langs die drywer op die Kasteelwa sit hoofartilleris Torr.

Coast gunners parbuckling the barrel of a 6-inch gun up a slope outside the Castle in July 1923.

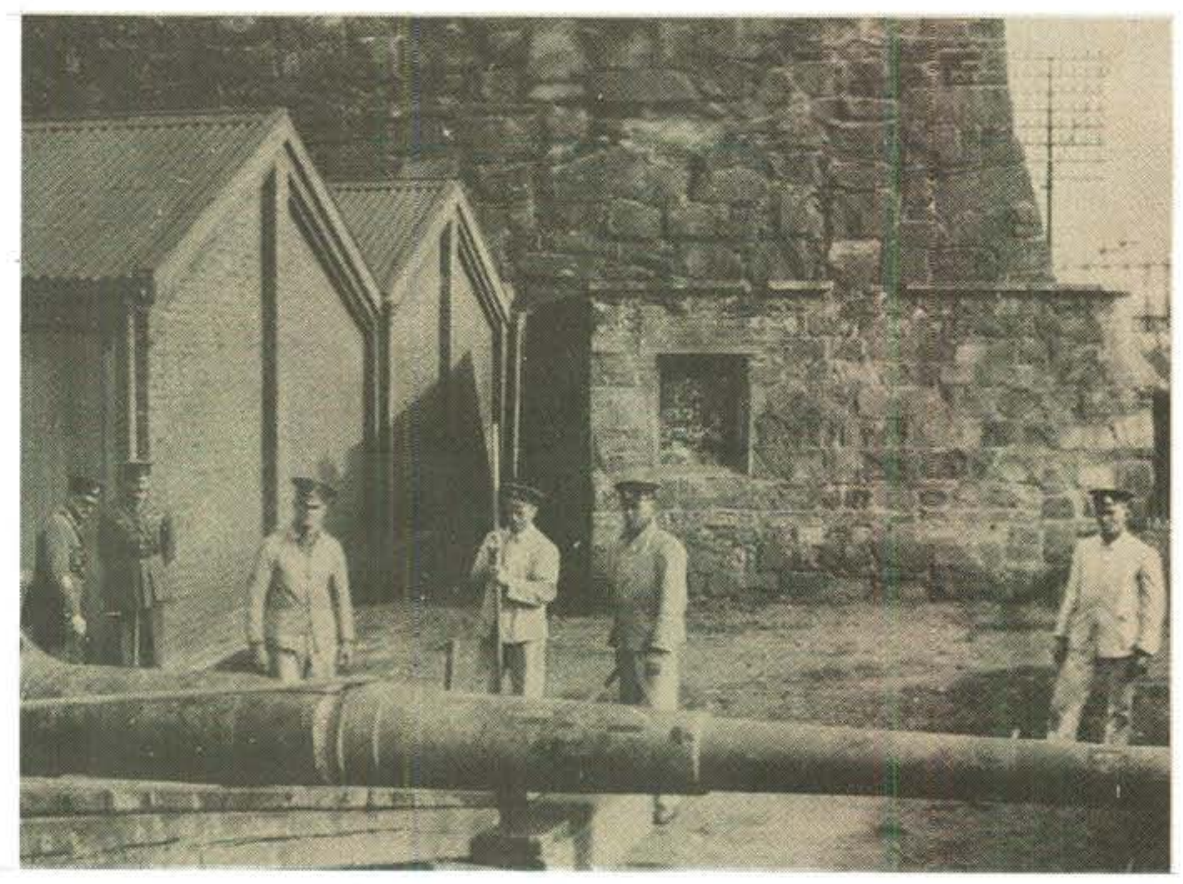

Antilleriste van die Vloot sleep die loop van 'n 6-duim kanon teen 'n steilte uit buite die Kasteel in Julie 1923. 


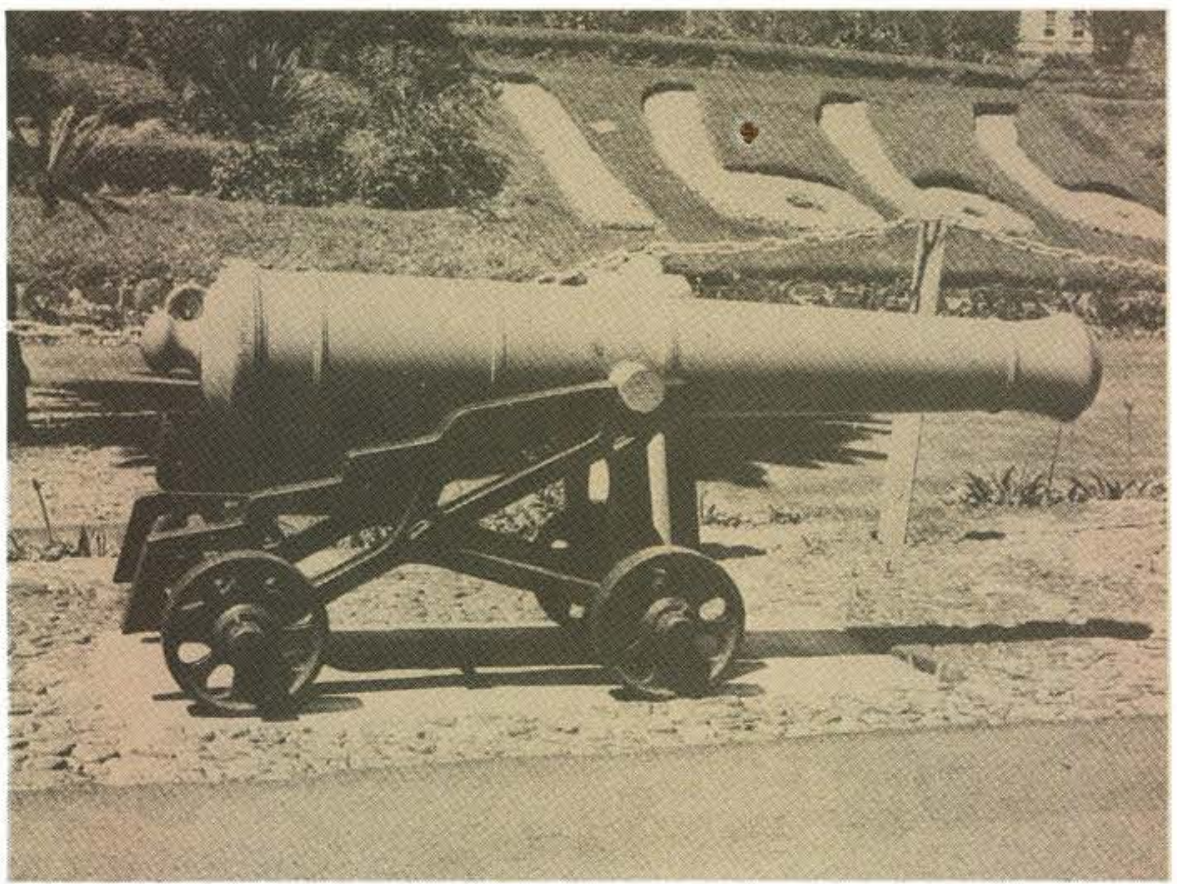

This 18-pounder smooth bore muzzle loader was the Cape Town time (noon) cannon until 1945 when a tap in the tonch hole accidentally broke off and necessitated its secret replacement with a similar gun which had previously occupied its present position in front of the lioness gateway to the Castle.

Hierdie 18-ponder voorlaaier was die Kaapstadse middagkanon tot 1945 toe een van die meganismes per ongeluk gebreek het. Die kanon is op 'n geheimsinnige wyse met 'n soortgelyke een vervang wat steeds voor die ingang na die Kasteel staan.

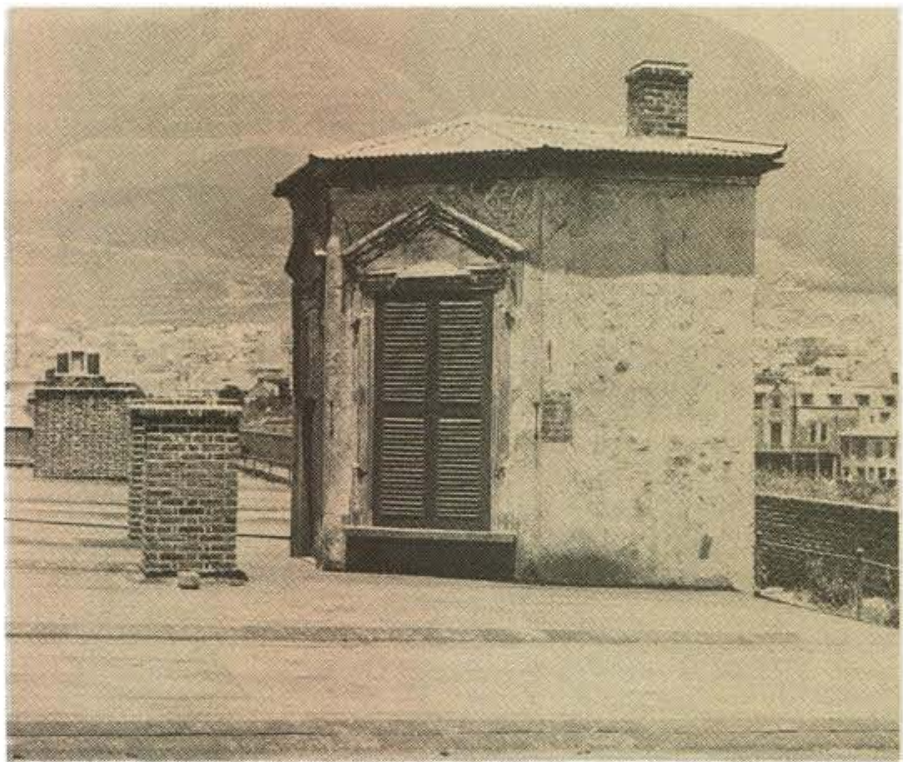

The Captain's Tower from where the Officer Commanding of the Castle's artillery gave orders to the gunners. Presently it is used by the Command's barber.

Die kaptein se toring vanwaar die Bevelvoerder van die Kasteel Artillerie opdragte aan die artilleriste gegee het. Dit word nou deur die Kommandement se barbier gebruik. 
Military training and service

Post War period

\section{Militêre opleiding en diens}

\section{Na-Oorlogse tydperk}

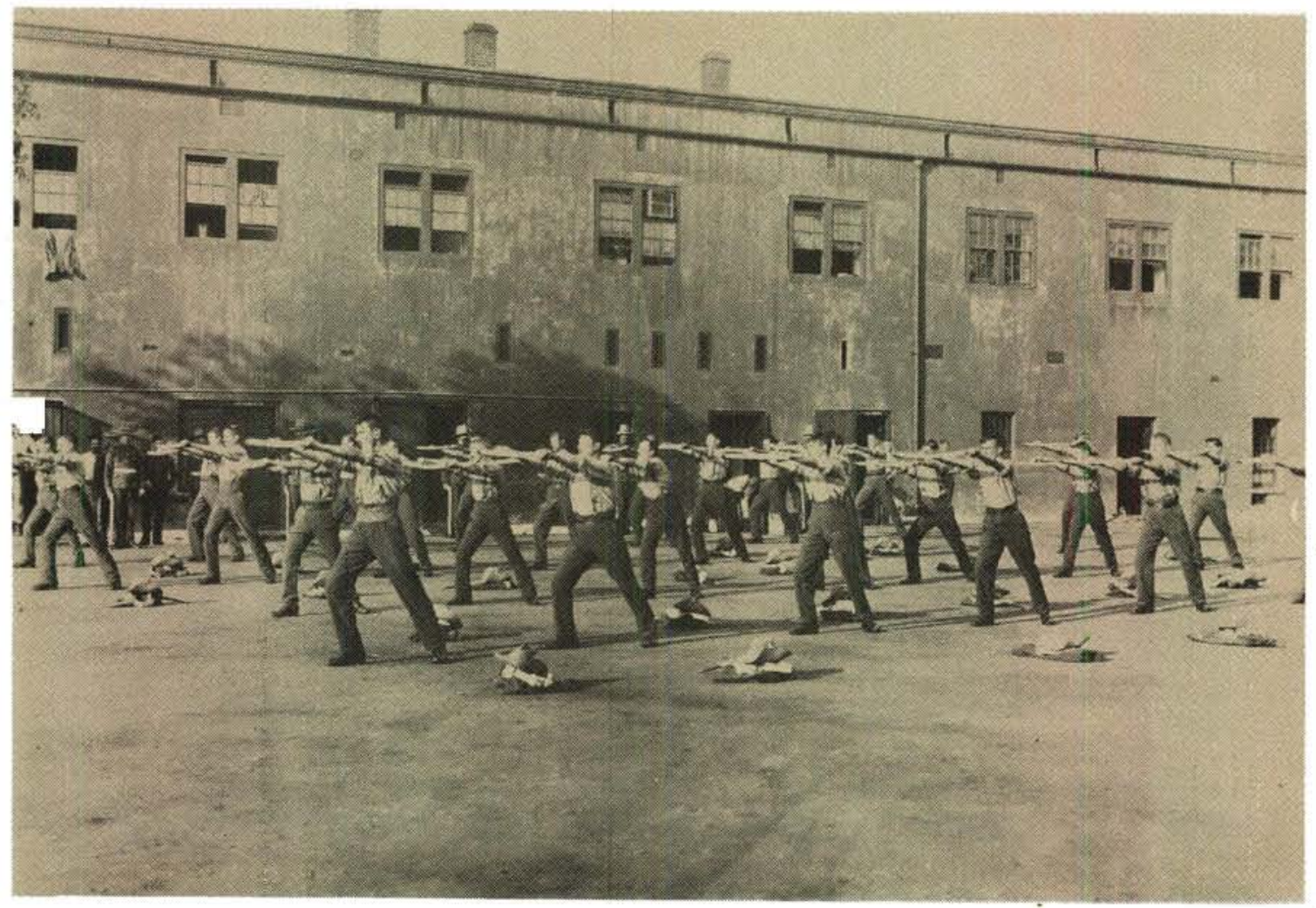

Physical training for colonial troops whose Australian bush hats may be seen on the ground.
Liggaamsoefeninge vir koloniale troepe wie se Australiese boshoede op die grond gesien kan word.
The Mobile Watch in the Inner Courtyard in January 1959.

Die Mobiele Wag in die binnehof van die Kasteel, Januarie 1959.

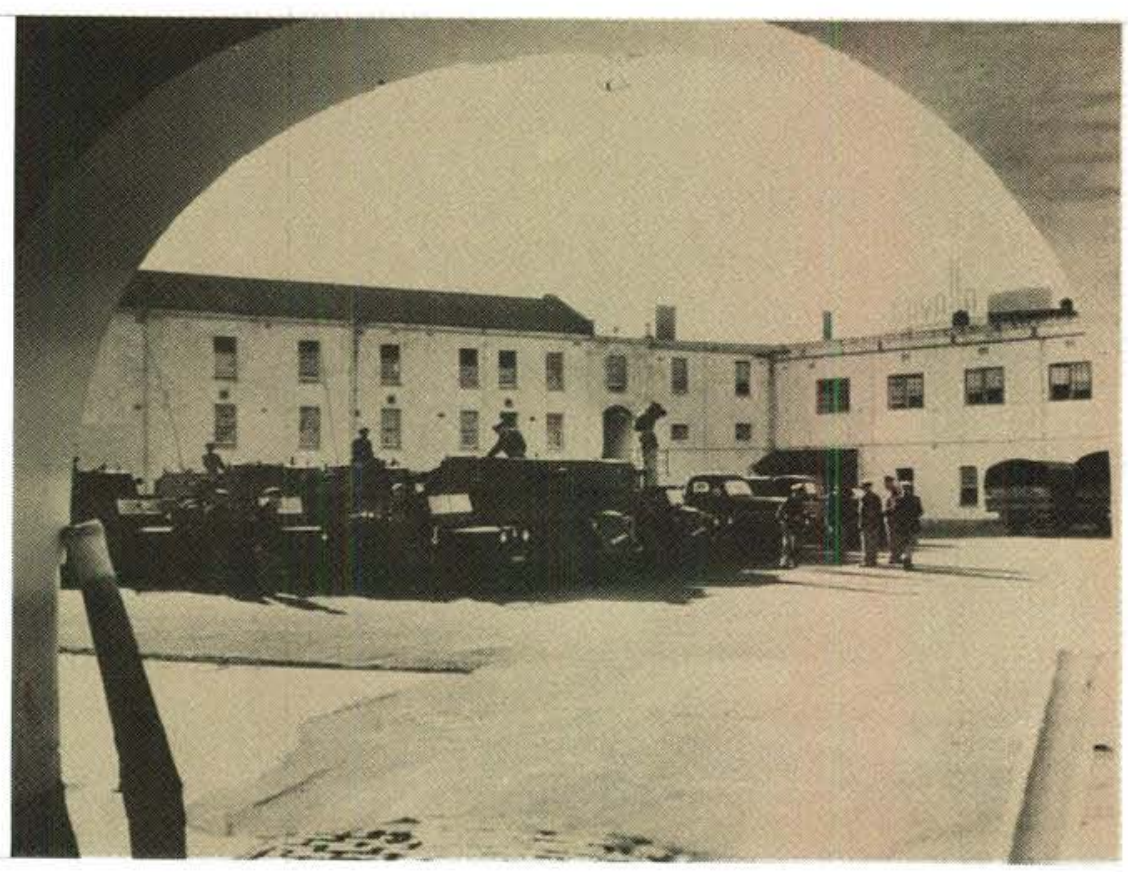




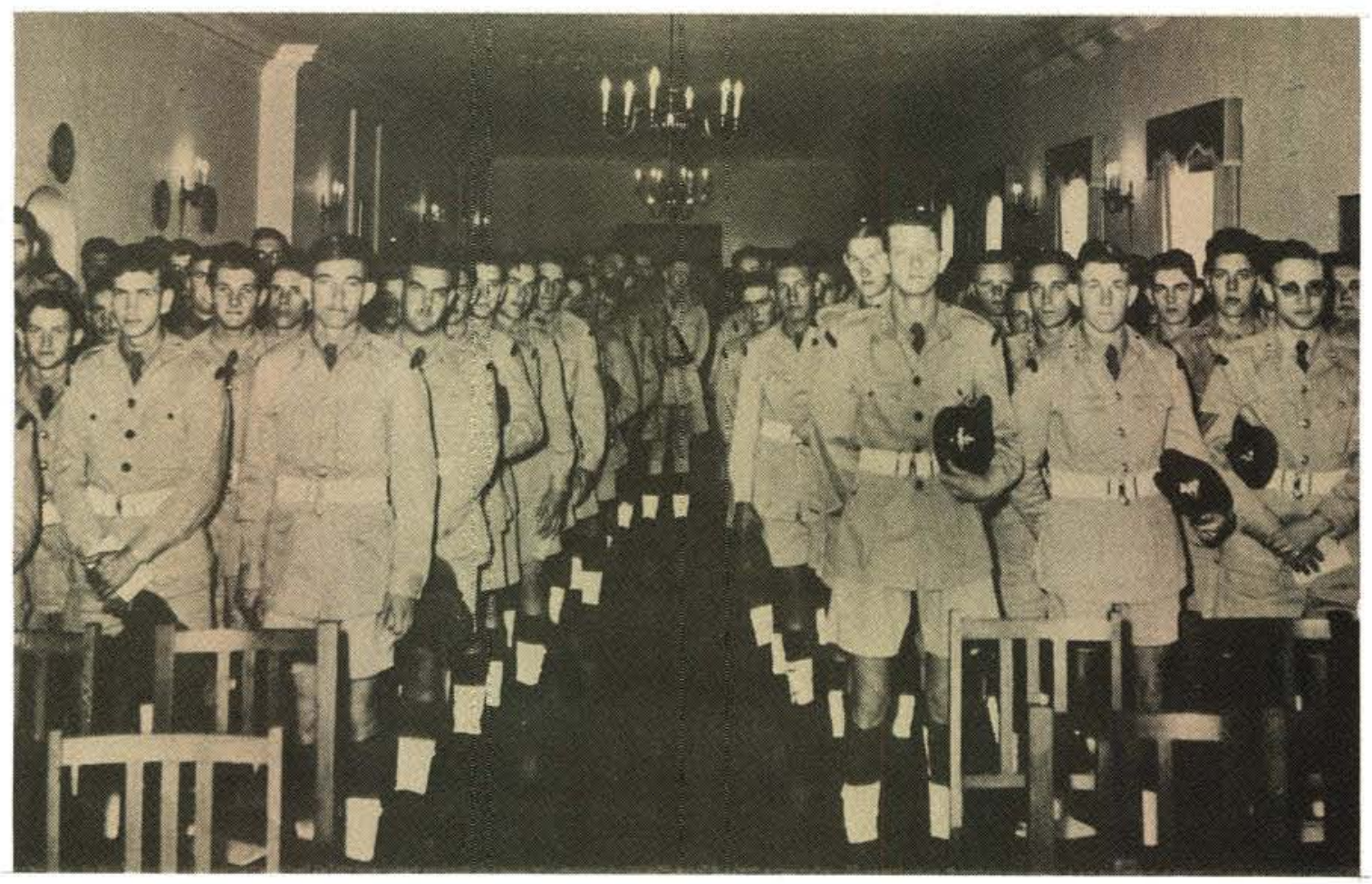

Church parade in the Lady Anne Barnard Ballroom for members of the Cape Field Artillery circa 1963.

Friday Church parade in the Inner Courtyard for personnel of Western Province Command Headquarters in 1979.
Kerkparade in die Lady Anne Barnard Balsaal vir lede van die Cape Field Artillerie in 1963.

Kerkparade op Vrydag in die binneplaas vir personeel van Kmamt WP HK in 1979.

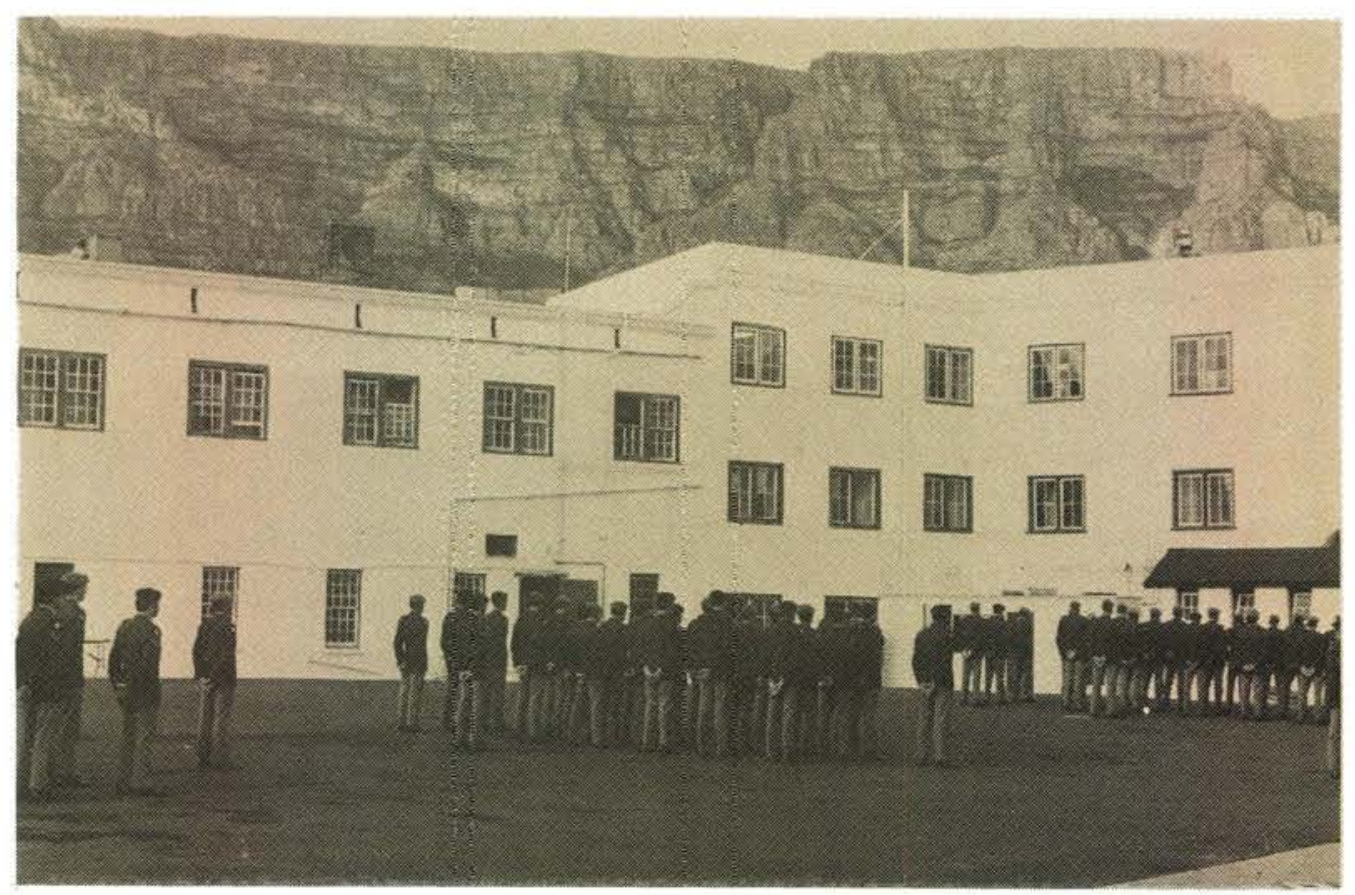




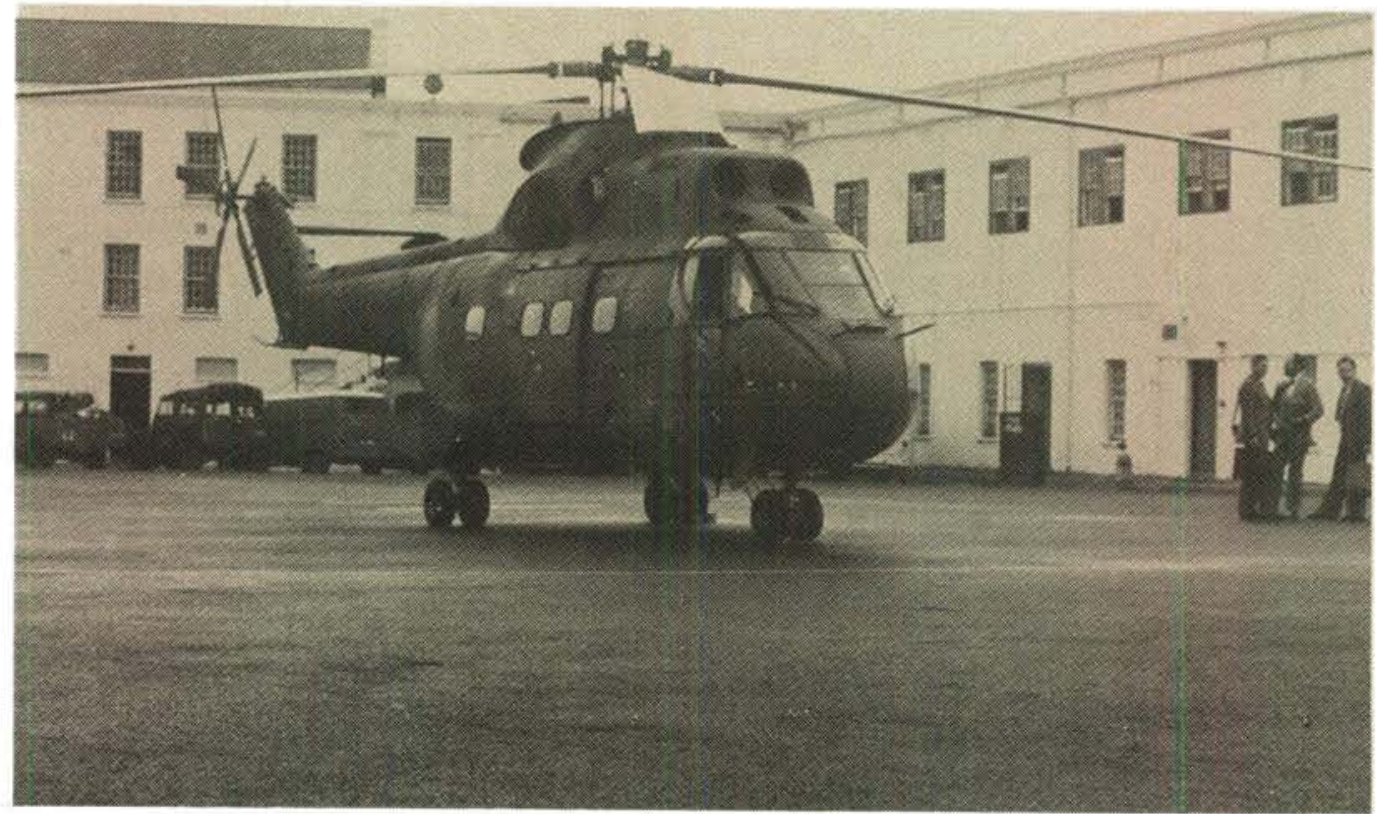

A Puma helicopter in the Inner Courtyard in the late 1970's.

The thrilling mock-attack on the Castle by the State President's Guard. 'n Puma-helikopter in die binneplaas in die laat sewentigerjare.
Die skynaanval wat die Staatspresidentswag op die Kasteel gedoen het.

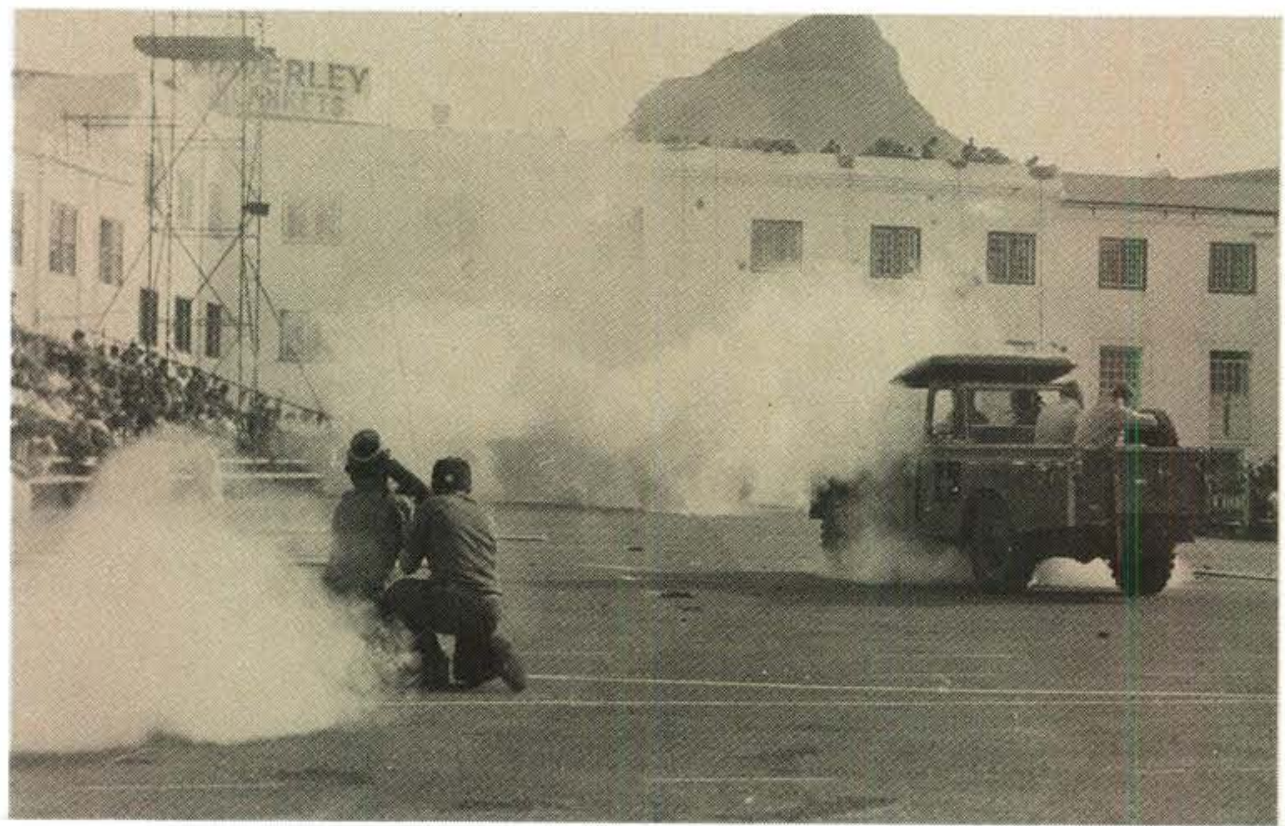




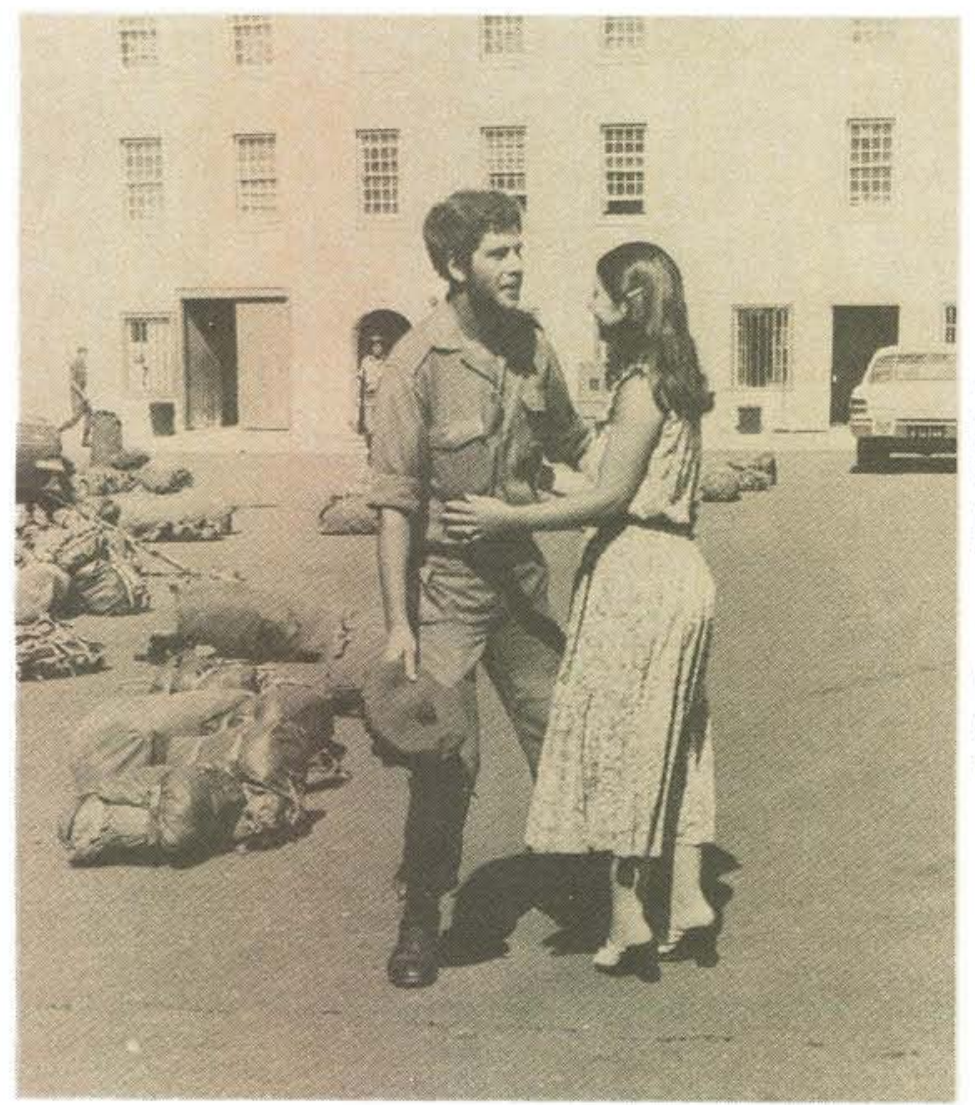

A joyful reunion at the Castle for a Cape Town Highlander home from Border duty in time for Christmas in December 1978.

in Vreugdevolle herontmoeting vir 'n Cape Highlander wat betyds terug is van die grens vir Kersfees 1978.

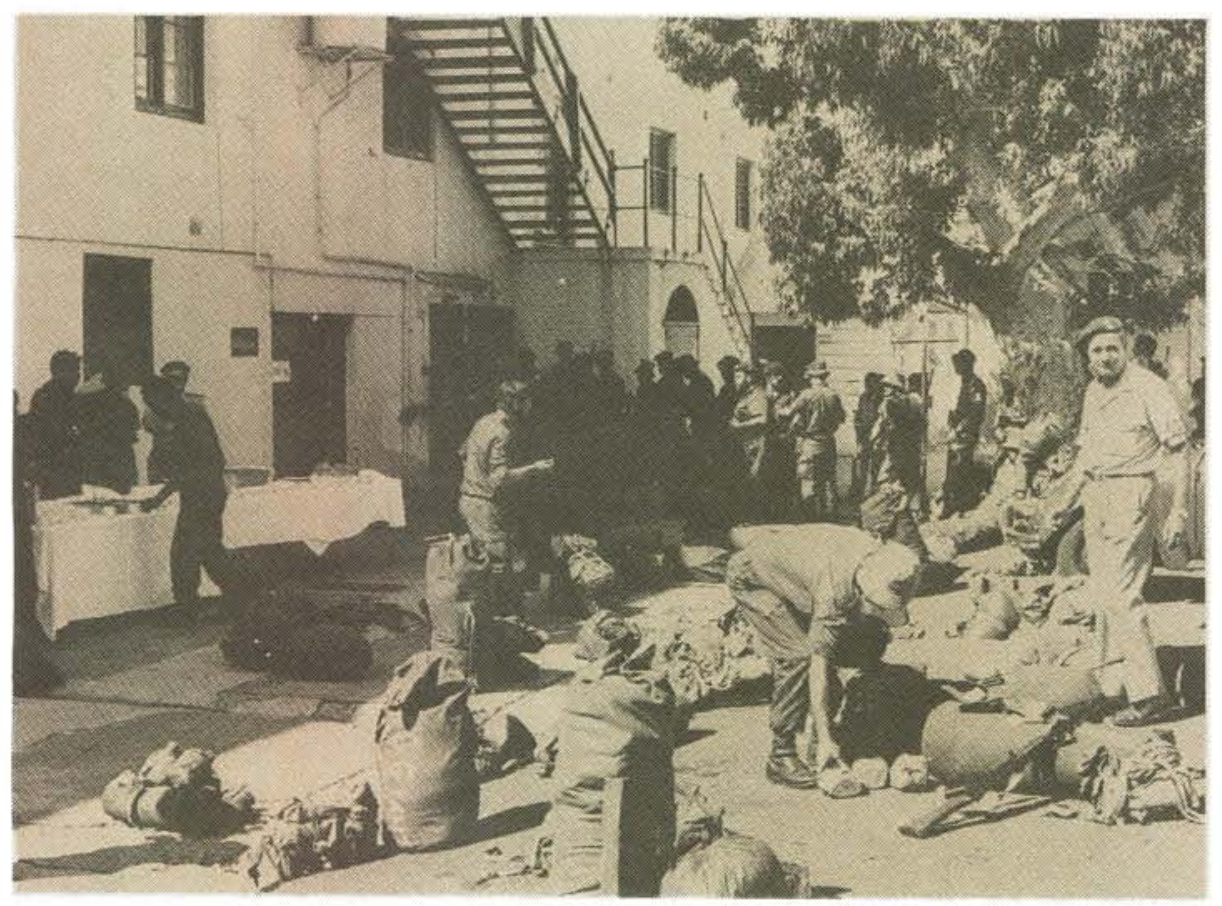

Light refreshments for men home from the border in time for Christmas in December 1978. Supervising operations are Commandant $A$. Moëlich partly obscured by the soldier in front of the table and the Command Regimental Sergeant Major, WOI W.J. Nell, on the extreme right.

Ligte verversings vir die manne wat betyds vir Kersfees 1978 van die grens teruggekeer het. Toesighoudend is Kmat A. Moëlich, wat agter die soldaat voor die tafel uitsteek en RSM, AOI W.J. Nell heel regs. 


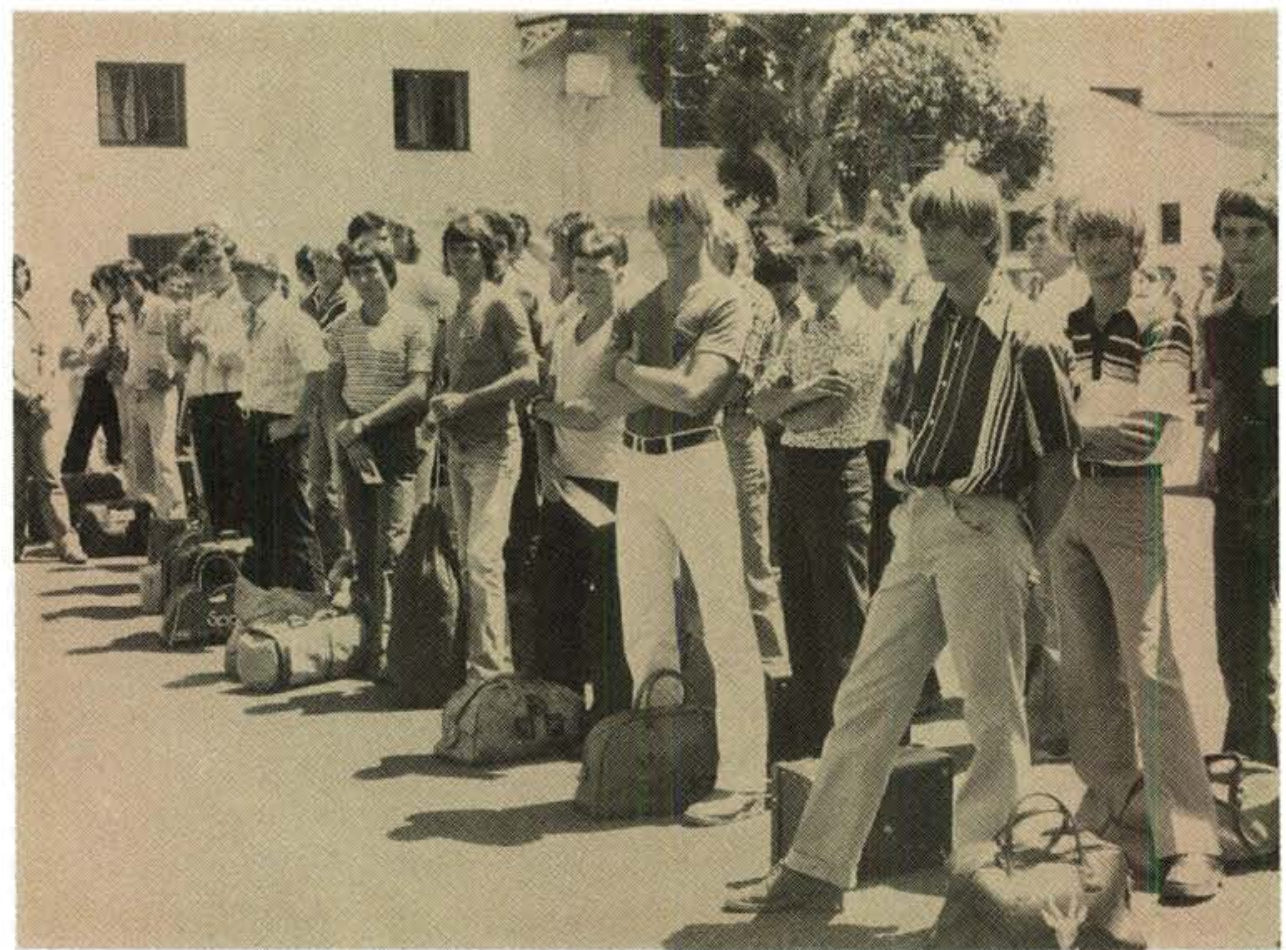

For many years young men from homes in the Cape Peninsula reported at the Castle before marching to the railway station to entrain for upcountry training bases. This photograph was taken in January 1980.

Vir etlike jare al rapporteer duisende jong manne vanaf die Kaapse Skiereiland by die Kasteel voordat hulle na die stasie marsjeer om na opleidingsbasisse dwars oor die land te vertrek.

Their first roll-call in the historic Castle of Good Hope in January 1980.

Hulle eerste kennismaking met die presensielys by die geskiedkundige Kasteel die Goeie Hoop in Januarie 1980.

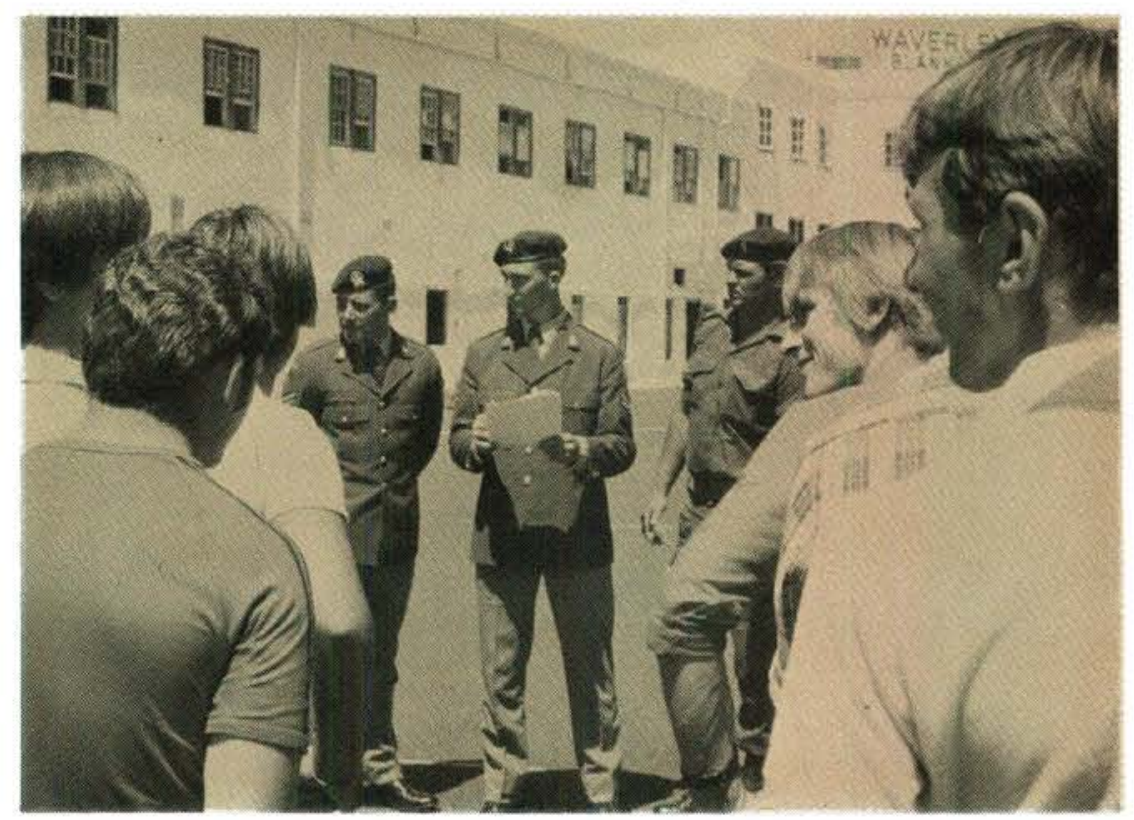




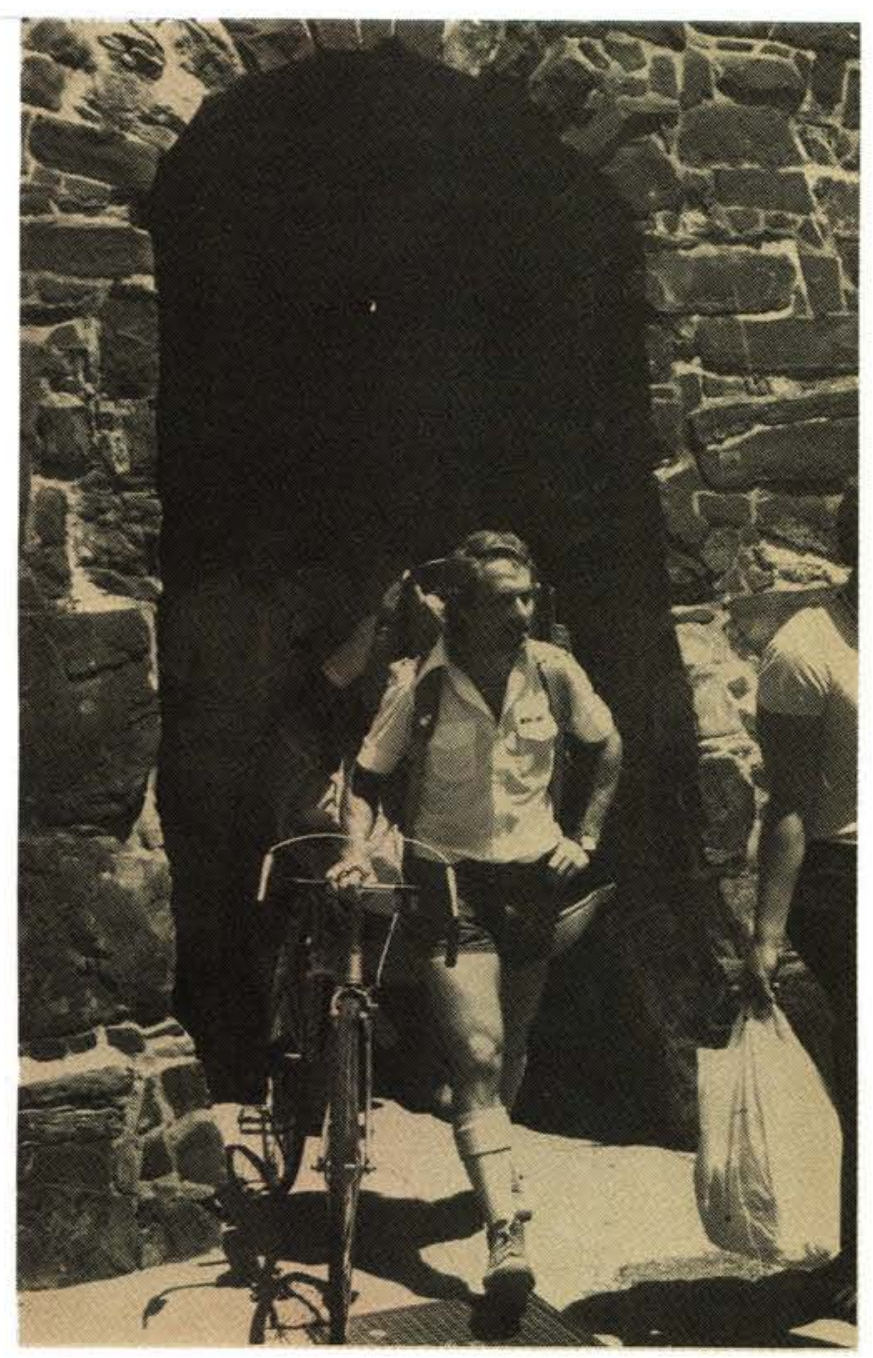

National Servicemen pass through the Sally Port at the Castle on their way to Cape Town Station in January 1980.

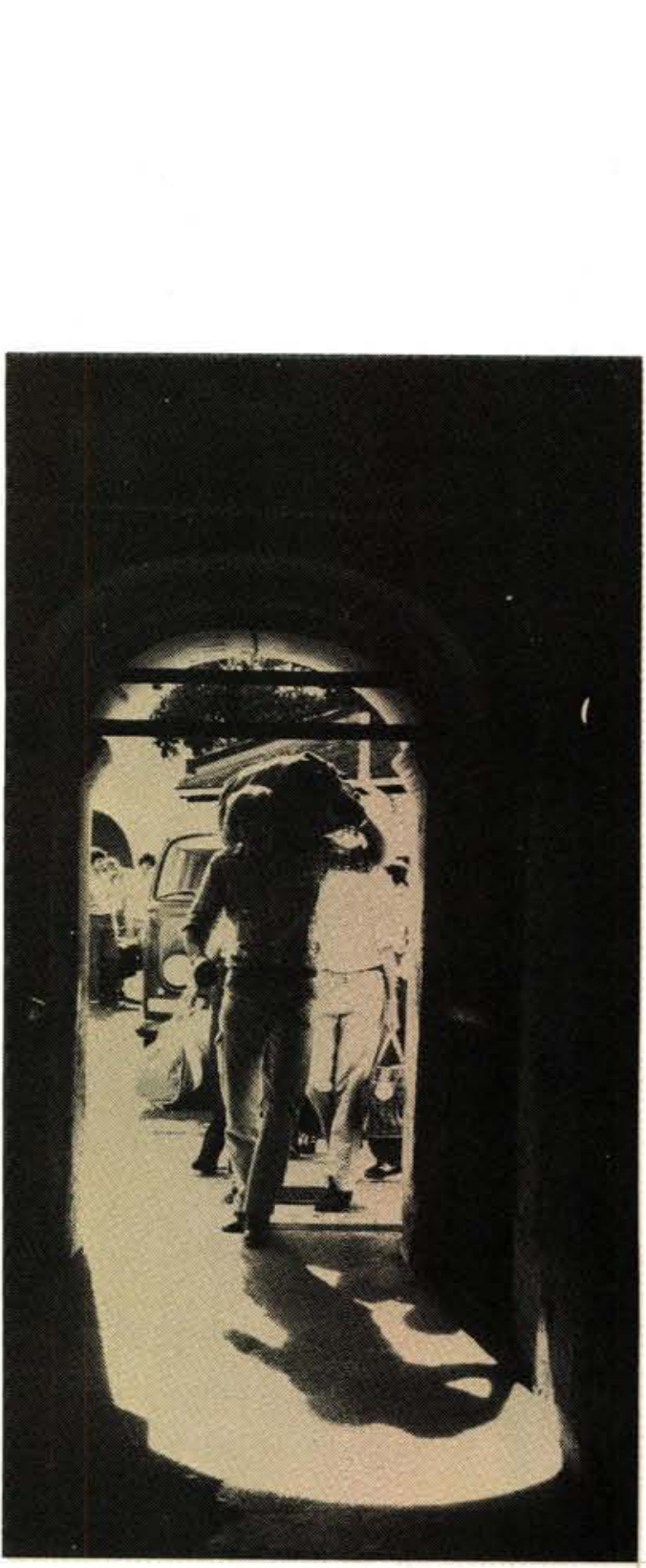

Nasionale Dienspligtiges gaan deur die Uitvalspoort by die Kasteel op pad na die Kaapstadstasie in Januarie 1980. 


\section{As accommodation for Governors, Commanding Officers and Officers}

\section{As huisvesting vir Goewerneurs, Bevelvoerders en Offisiere}

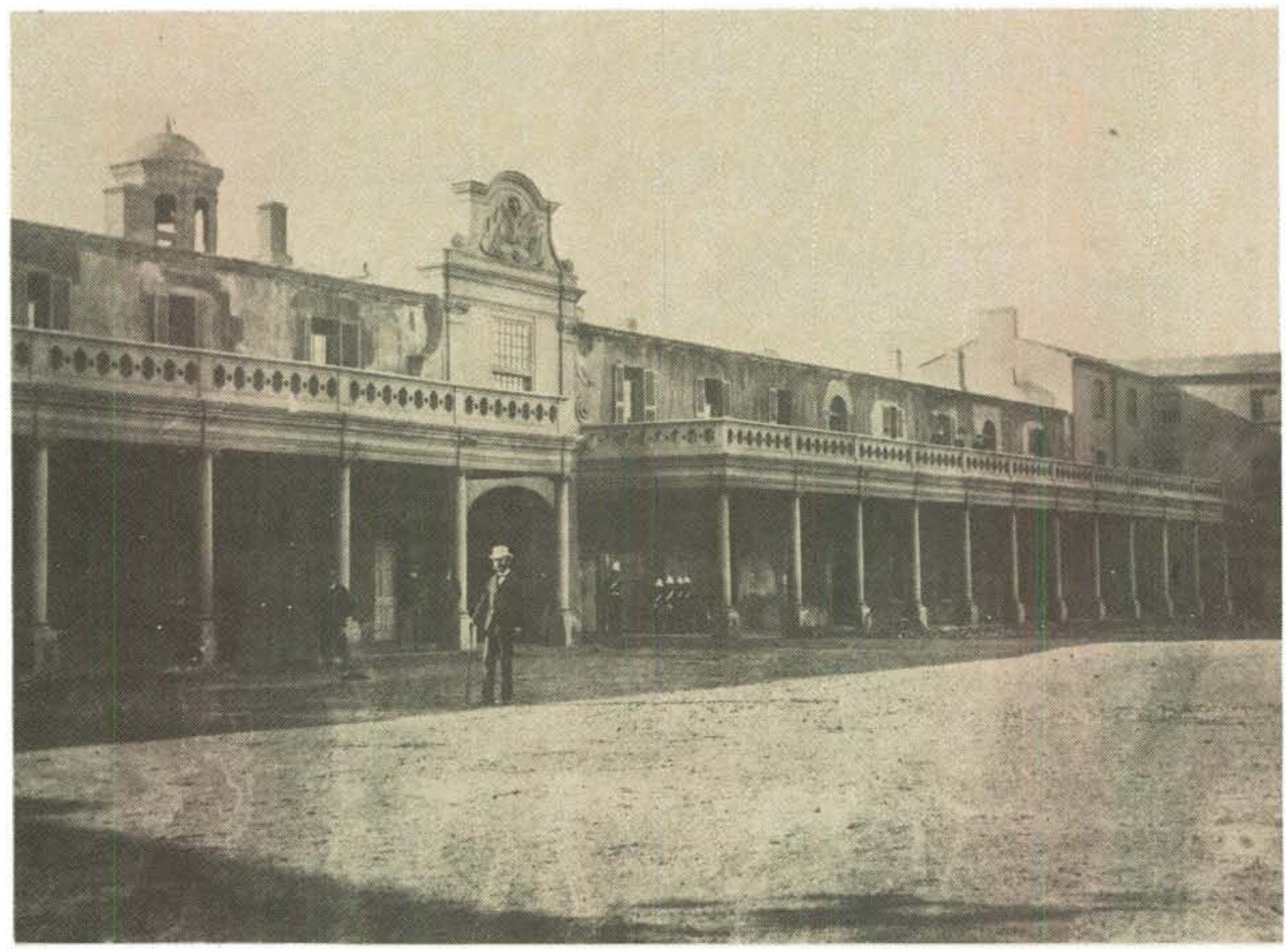

When the Governor moved to Government House in the Gardens, the Government House in the Castle became the residence of the General Officer Commanding. Colonel B.C. Judd. He visited Gen Sir William Gordon Cameron, GCB, in 1893 and lunched with him and his family on the roof of his quarters part of which was decorated with flowers and shrubs in tubs.

Nadat die Goewerneur na Goewermentshuis in die Tuine verhuis het, het die Goewermenthuis in die Kasteel die tuiste geword van die Bevelvoerder, kol B.C. Judd. Hy het genl sir William Gordon Cameron, GCB, in 1893 besoek en middagete saam met hom en sy familie genuttig op die dak van sy kwartiere, wat met blomme en struike versier was. 


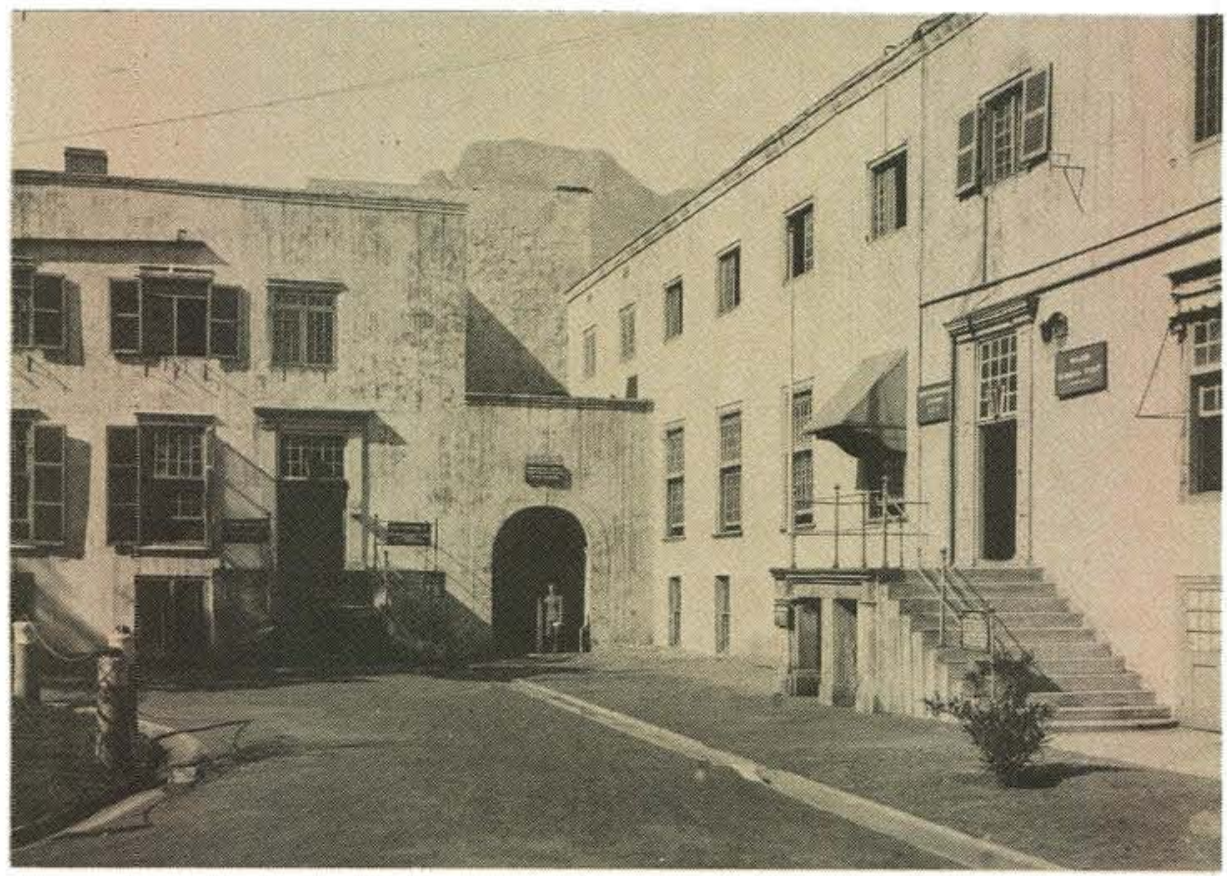

The former Government House left and General's office (right) at the Castle circa 1911. When this photograph was taken the General's official residence was no longer the former Government House but Charlie's Hope in Rosebank.

Die vroeëre Goewermentshuis (links) en die Generaal se kantoor (regs) by die Kasteel omstreeks 1911. Toe hierdie foto geneem is, was die Generaal se amptelike tuiste nie meer die vroeëre Goewermentshuis nie, maar "Charlies Hope" te Rosebank.

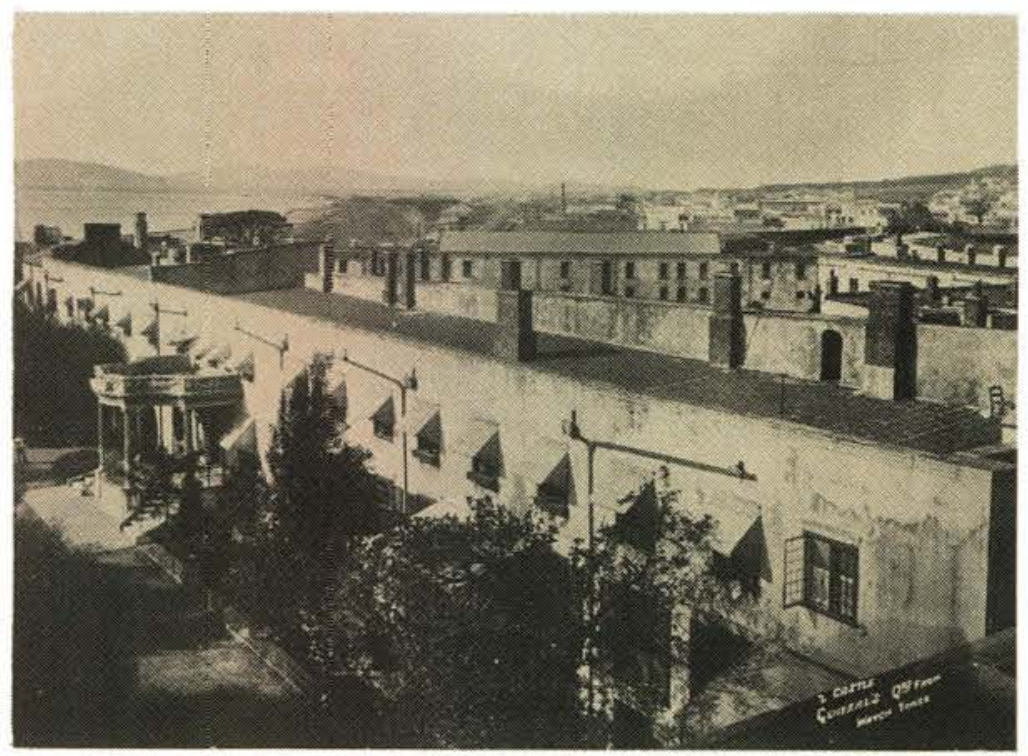

The Outer Courtyard at the end of the 19th Century. The 1912 plan of the Castle shows that the upstairs rooms on the right of the archway were officer's quarters. Those on the left were the Garrison Officer's Mess which consisted of a billiard room, mess room and pantry.

Die buitenste Binnehof teen die einde van die 19de eeu. Die 1912 plan van die Kasteel toon dat die boonste vertrekke, regs van die boog, offisierskwartiere was. Dié aan die linkerkant was die Garnisoen Offisiersmenasie wat uit 'n snoekerkamer, eetkamer en 'n spens bestaan het. 
The official residence of the British General when it was transferred to the Union Government on 1 December 1921.

Die amptelike woning van die Britse Bevelvoerder aan die Kaap toe dit oorgedra is aan die Unieregering op 1 Desember 1921.
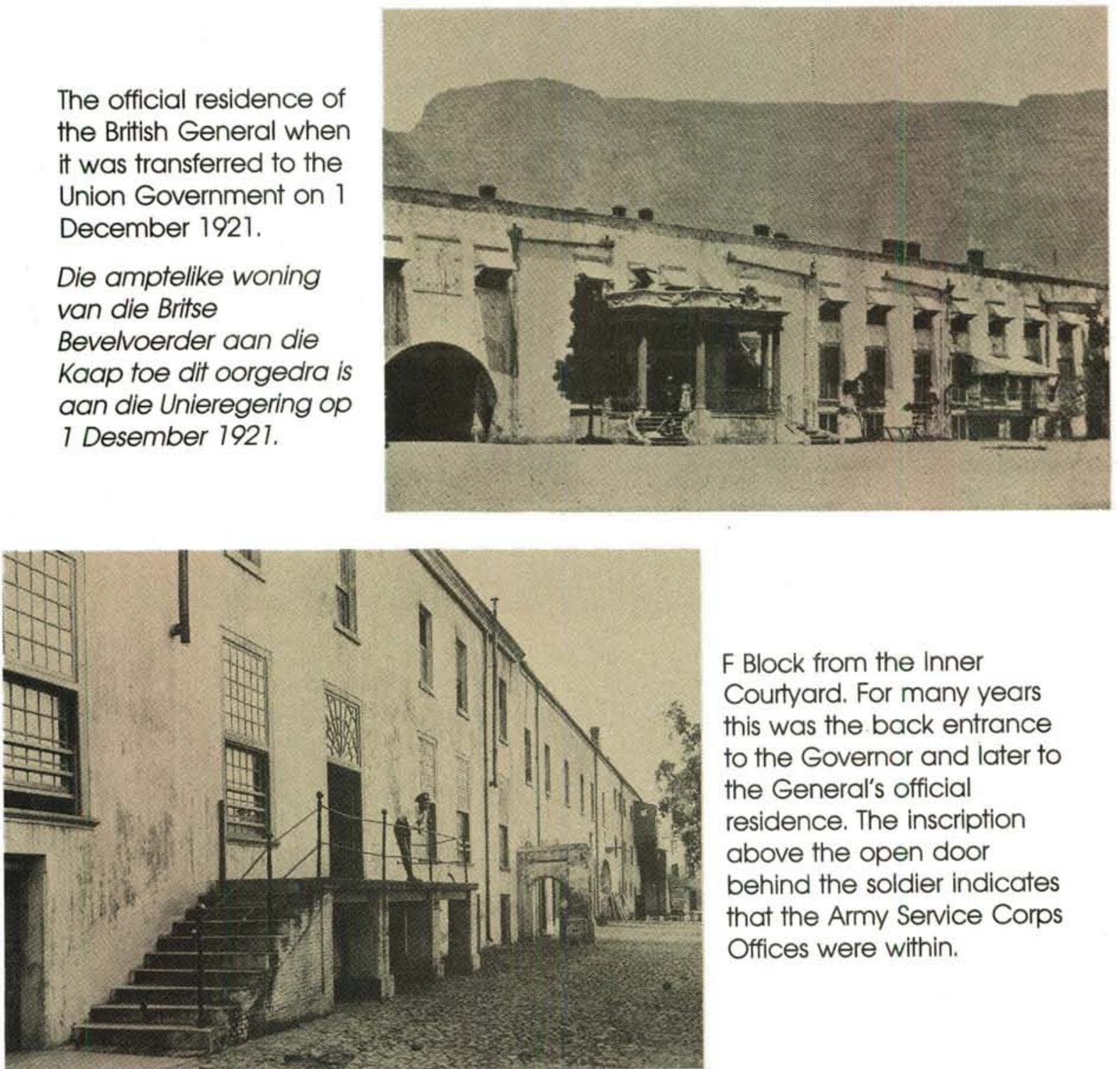

F Block from the Inner Courtyard. For many years this was the back entrance to the Governor and later to the General's official residence. The inscription above the open door behind the soldier indicates that the Army Service Corps Offices were within.

F Blok vanaf die interne binnehof gesien. Dit was vir baie jare die agterste ingang na die Goewerneur en later die Generaal se amptelike woning. Die inskripsie bo-aan die oop deur, agter die soldaat, toon dat die Leër Dienskorps se kantore daar binne geleë was.

Entrance to the office of the Officer Commanding circa 1948.

Ingang na die Bevelvoerder se kantoor ongeveer 1948.

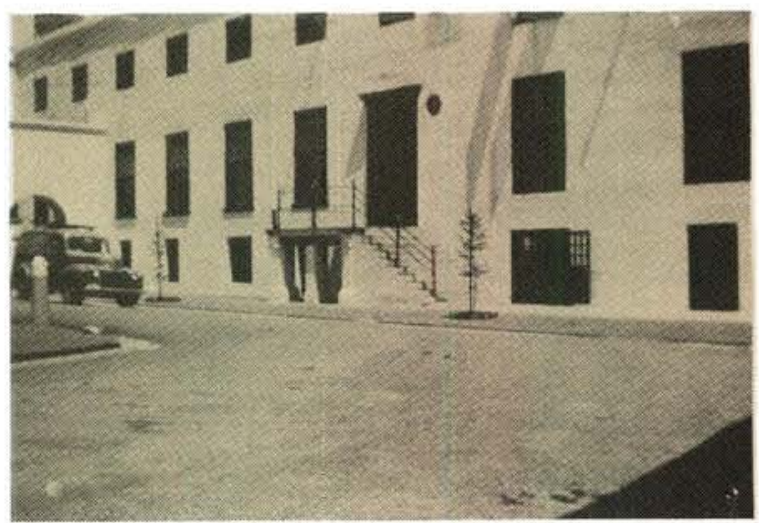




\section{As barracks for troops As troepebarakke}

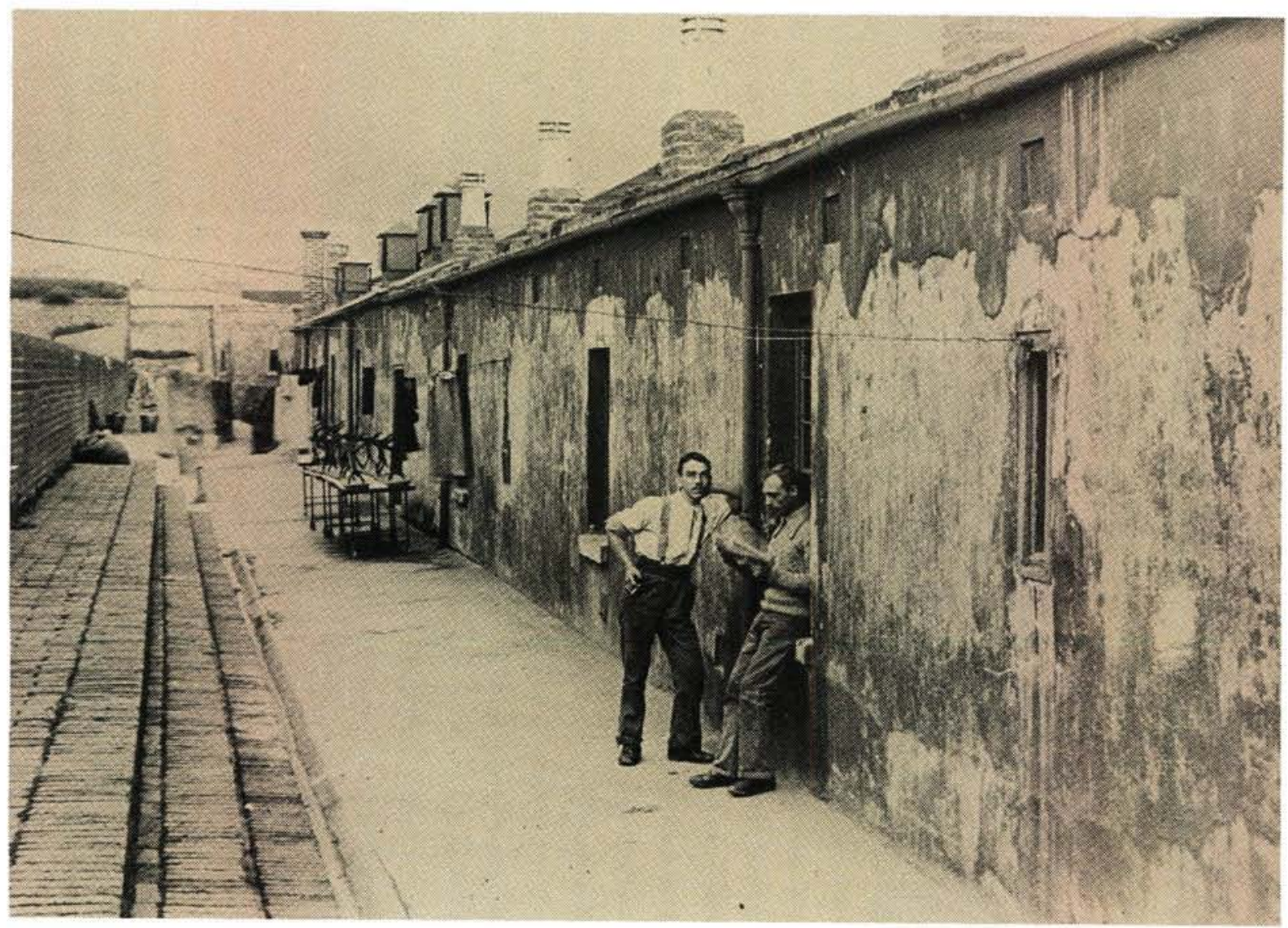

The battlements between Katzenellenbogen and Nassau bastions. In 1913 the area which is now the Maritime Museum was divided into barrack rooms 13 and 14 each of which housed 28 men. Roughly midway between the bastions part of the three tiered firestep (on the left) was removed and showers and urinals were built there. These were demolished in 1977. In May 1959 arrangements were made for SA Defence Force sodliers on casual leave in Cape Town to be housed in these barrack rooms.

Die borswering tussen Katzenellenbogen en Nassau bastions. In 1913 is die gebied wat vandag die Maritieme Museum is, verdeel in barakke 13 en 14 wat elk 28 man gehuisves

het. Ongeveer halfpad tussen die twee bastions is 'n gedeelte van die drie-vlak brandtrappe (aan die linkerkant) verwyder en storte en urinale is daar gebou. Dit is in 1977 gesloop. Vanaf 1959 kon soldate wat met geleentheidsverlof in Kaapstad is, in hierdie barakke gehuisves word. 


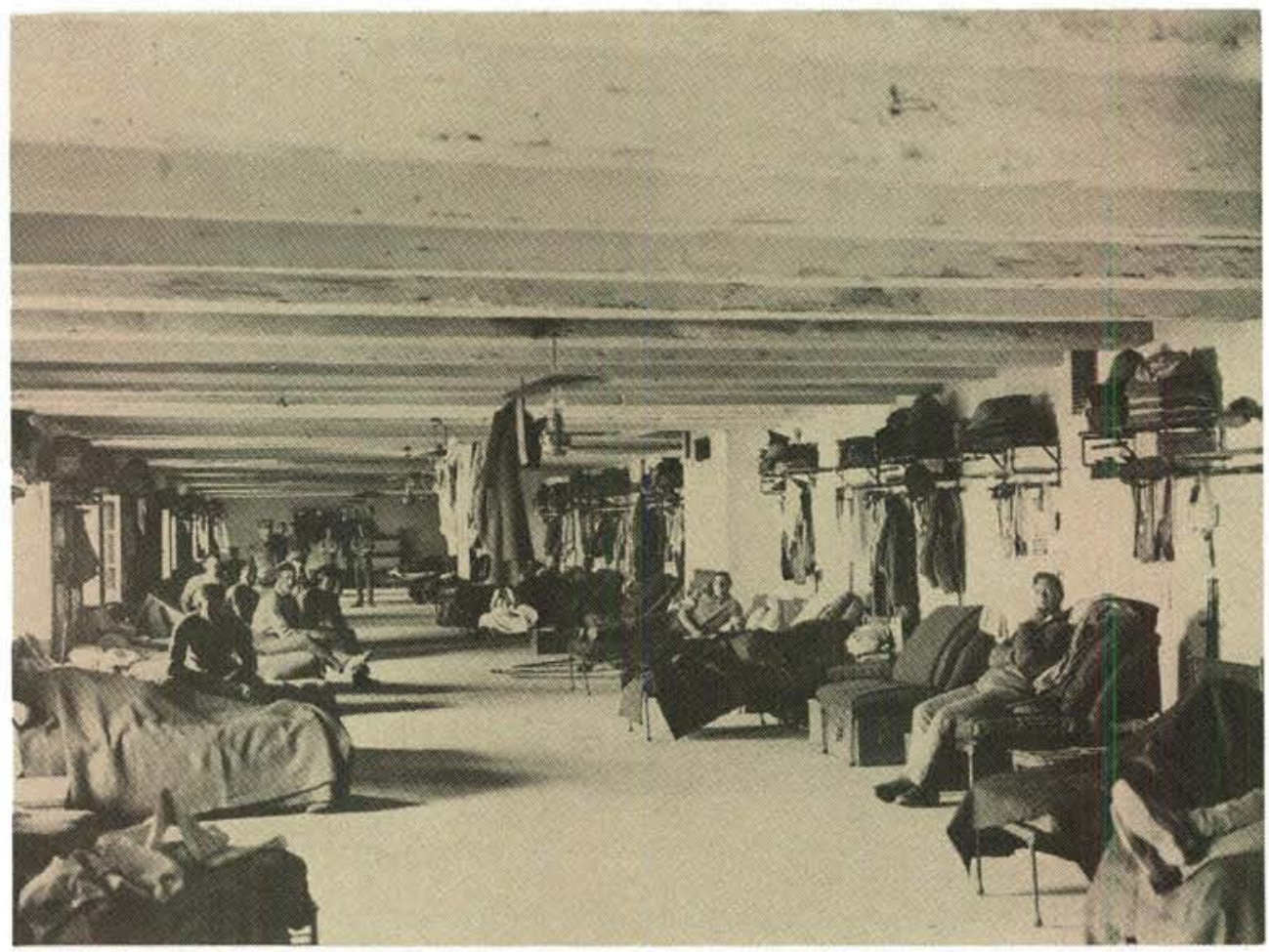

British Regular Army soldiers in their barrack room on the first floor of F Block in the Castle before the First World War. They complained that their rooms were unpleasantly hot in summer and cold and draughty in winter.

Britse Staandemag Leërsoldate in hulle barakke op die eerste vloer van blok $F$ in die Kasteel, voor die eerste Wêreldoorlog. Hulle het gekla dat hulle kamers ondraaglik warm was in die somer en koud en trekkerig in die winter.

The belfry seen from the battlements. The rooms on the left today house the Officer's Messes of the Cape Town Highlanders and Cape Town Rifles.

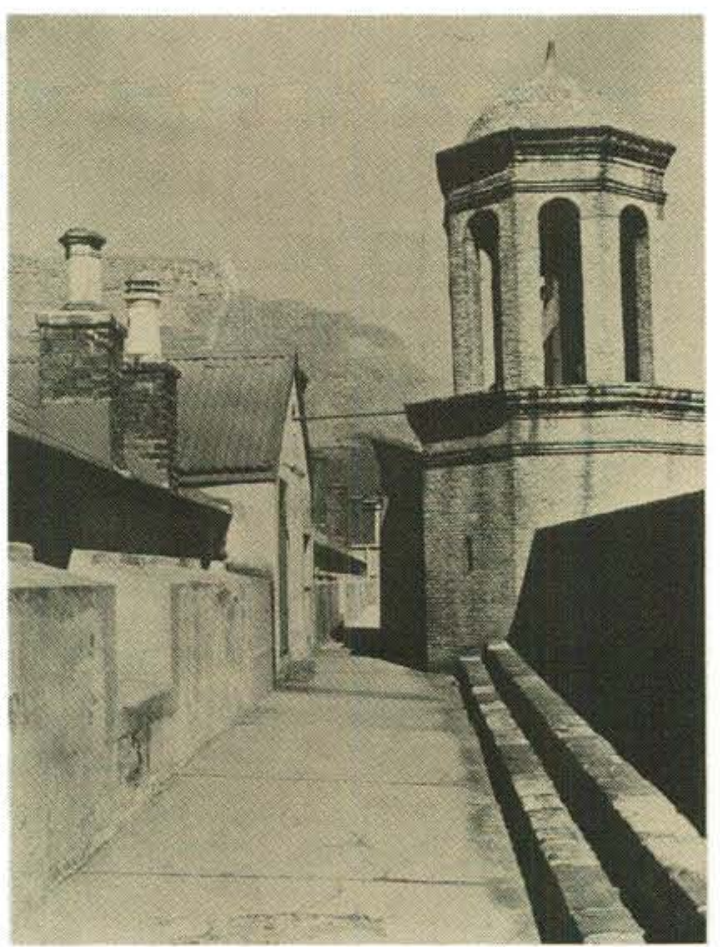

Die kloktoring gesien vanaf die borswering. Die vertrekke aan die linkerkant huisves tans die offisiersmenasie van die Cape Town Highlanders en Cape Town Rifles. 


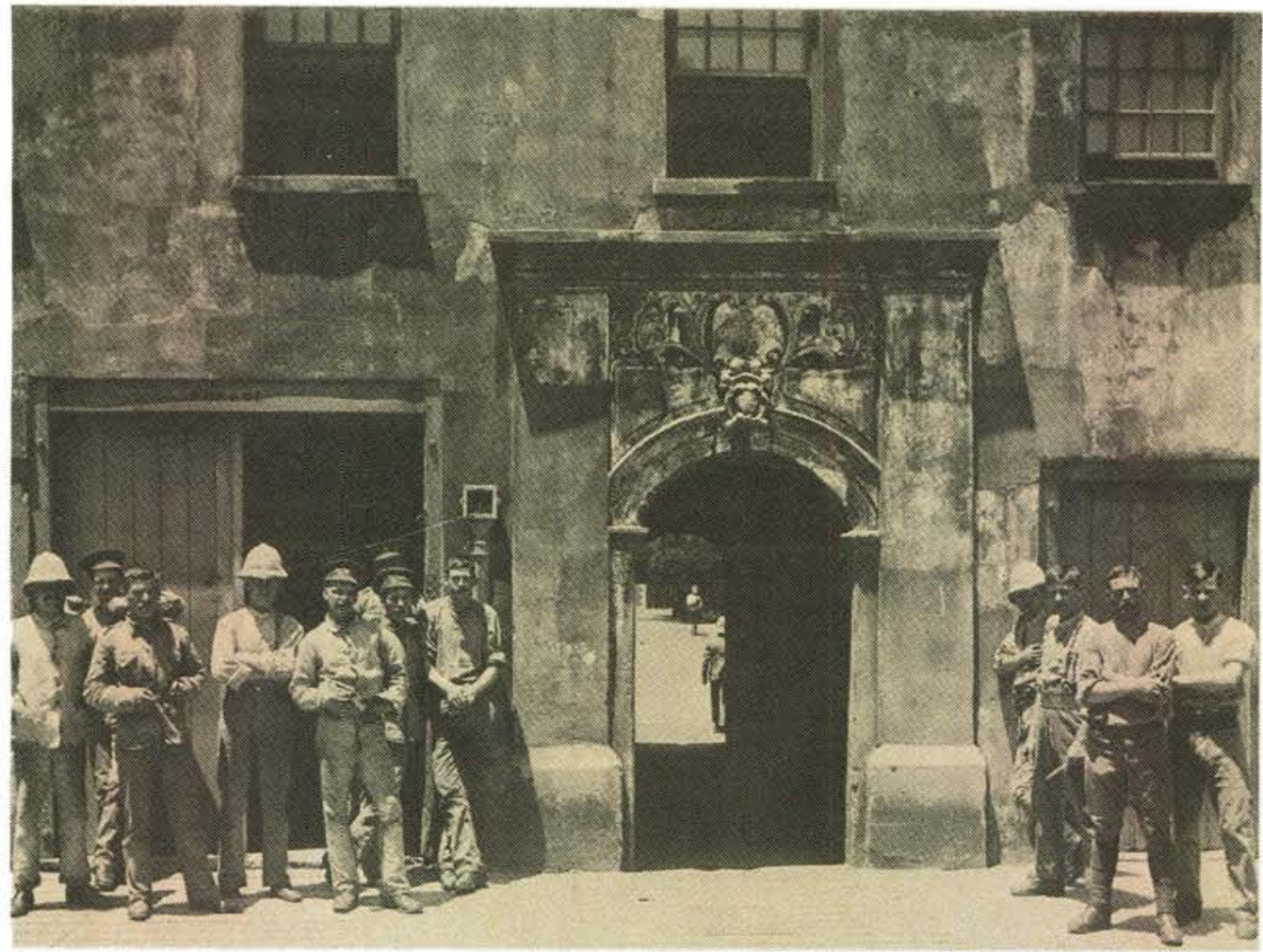

British Infantrymen outside the Sally Port between the Katzenellenbogen and Nassau bastions at the Castle. Notices above the doors on the left and right of the Sally Port indicate that these rooms were used for forage and groceries respectively.
Britse Infanterie buite die Uitvalspoort tussen die Katzenellenbogen en Nassau bastion by die Kasteel. Kennisgewings bokant die deure links en regs van die Uitvalspoort toon dat hierdie vertrekke gebruik is vir voer en kruideniersware onderskeidelik.

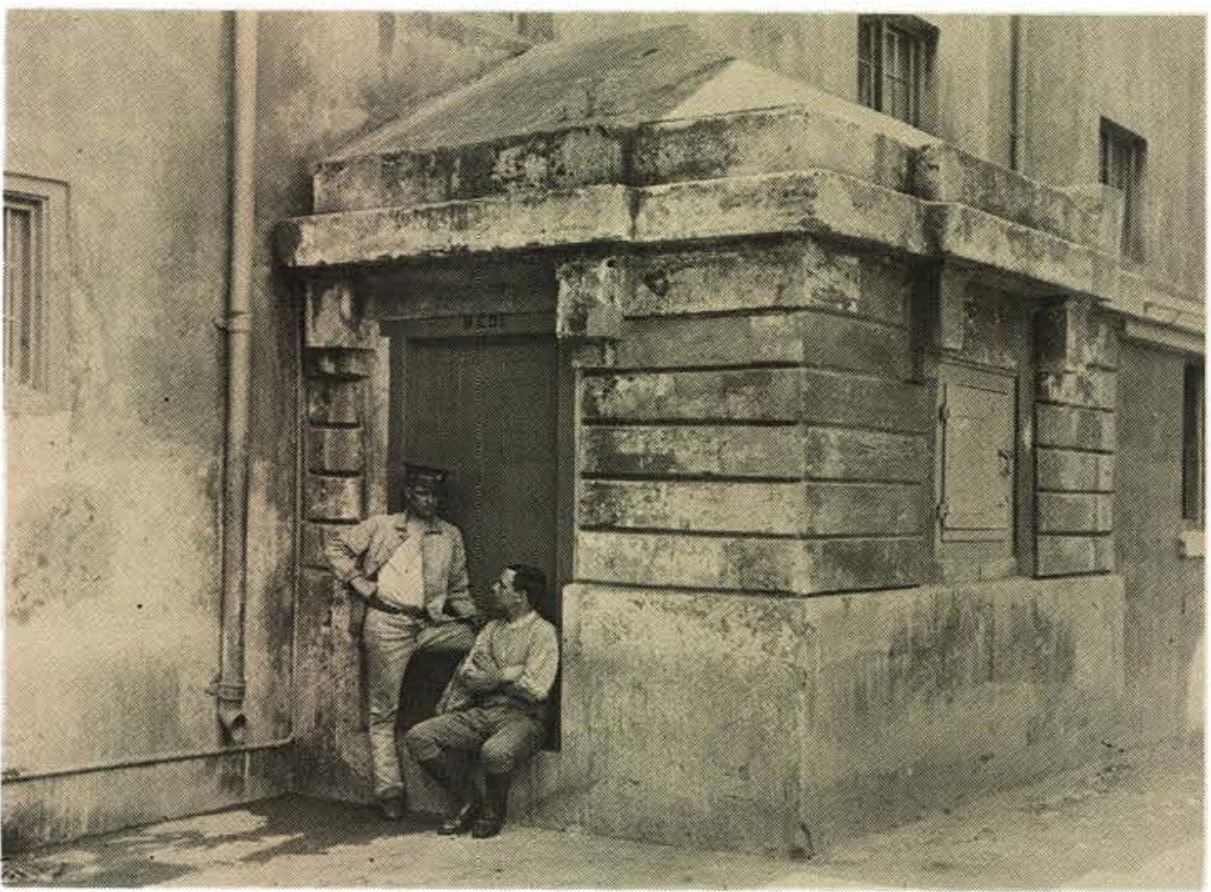

British riflemen are seen outside a Powder Magazine which was then used as a bedding store. Britse skutters word gesien buite die kruitmagasyn wat as linnestoor gebruik is. 
A barrack room in the Castle in April 1952.

'n Kasernekamer in die Kasteel in April 1952.
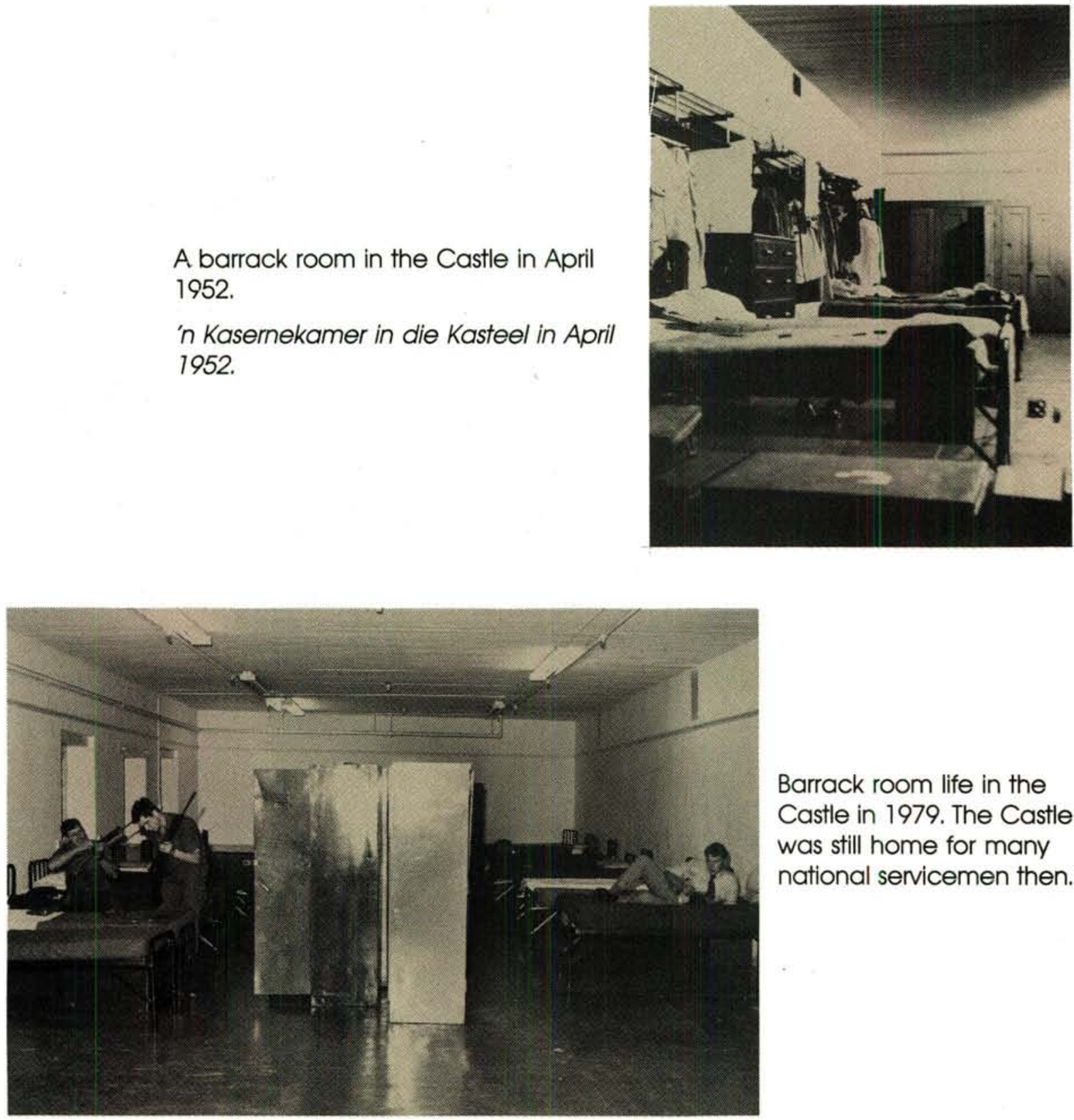

Barrack room life in the Castle in 1979. The Castle was still home for many national servicemen then.

Die kasernelewe in die Kasteel in 1979. Destyds was die Kasteel nog die tuiste van baie dienspligtiges.

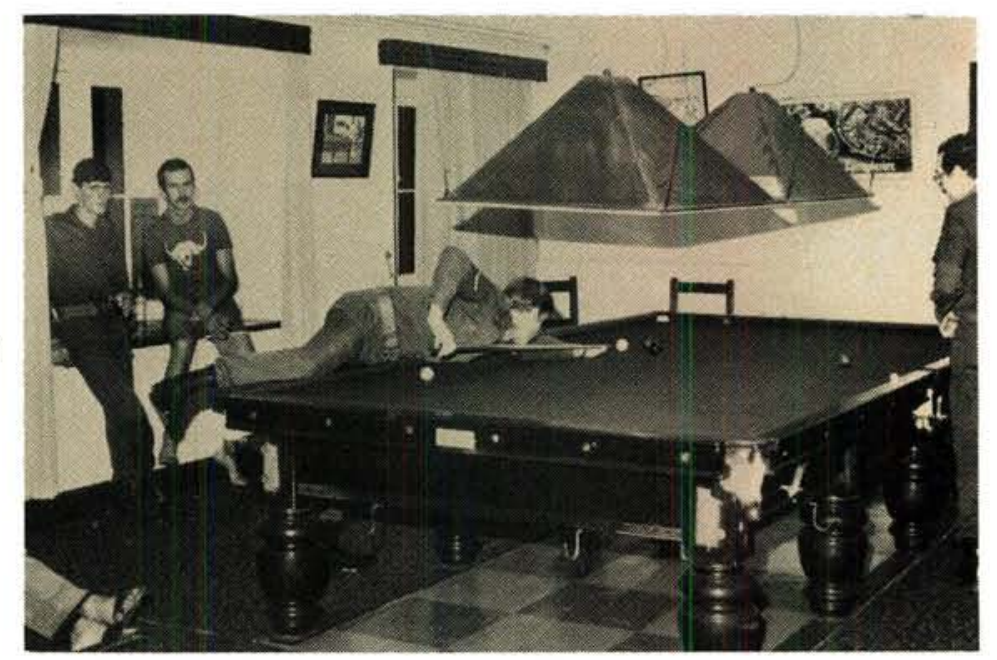




\section{Important visitors at the Castle}

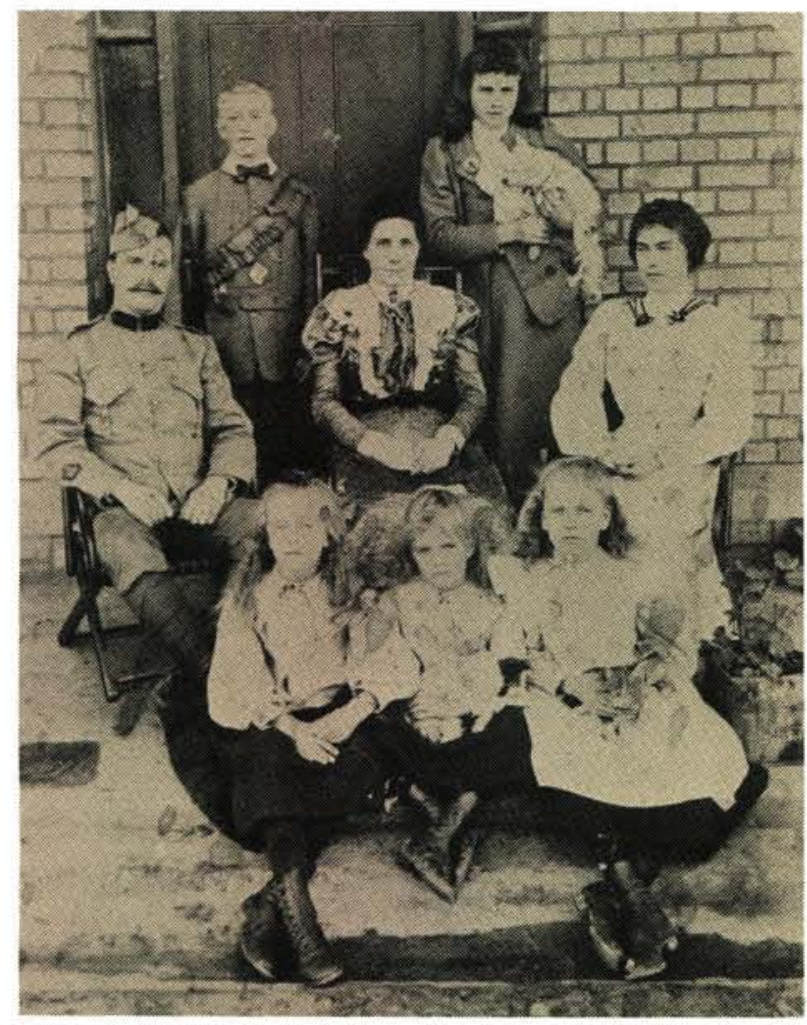

The British Garrison sergeant major at the Castle, Regimental Sergeant Major W.D.H. Beattie, with his wife and family circa 1896. He later rose to the rank of captain in the Union Defence Forces and settled in South Africa.

Die Britse Garnisoen sersant-majoor by die Kasteel, regiment sersant majoor W.D.H. Beattie, met sy vrou en kinders omstreeks 1896. Hy het later die rang van kaptein in die Unieverdedigingsmag beklee en hom in Suid-Afrika gevestig.

An Infantry Guard of Honour for a British Vice-Admiral, thought to be Vice-Admiral Sir Rudolph W. Bettinck, Commander-in-Chief South Atlantic (1922-25). At this time the walls of the Castle were light brown.

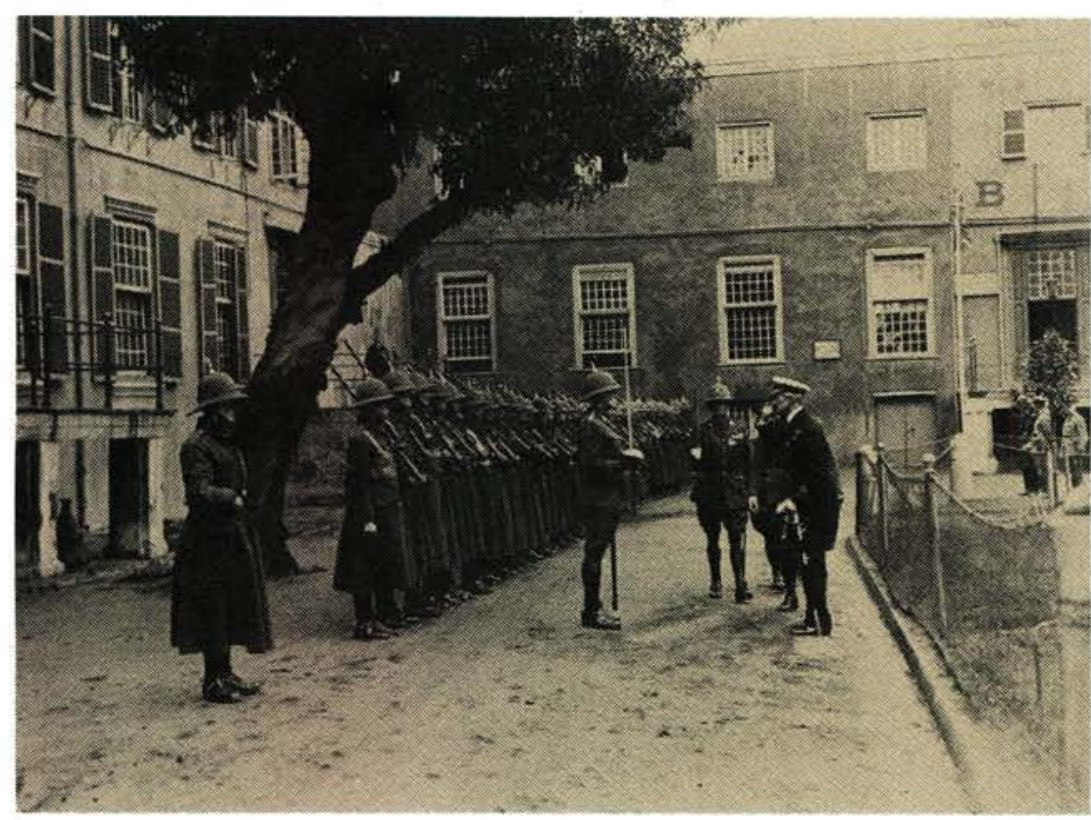

'n Infanterie erewag vir 'n Britse vise-admiraal, vermoedelik $v$-adm/ sir Rudolf W. Bettinck, Opperbevelhebber van die Suid-Atlantiese Oseaan (1922-1925). Die mure van die Kasteel was op dié stadium ligbruin. 


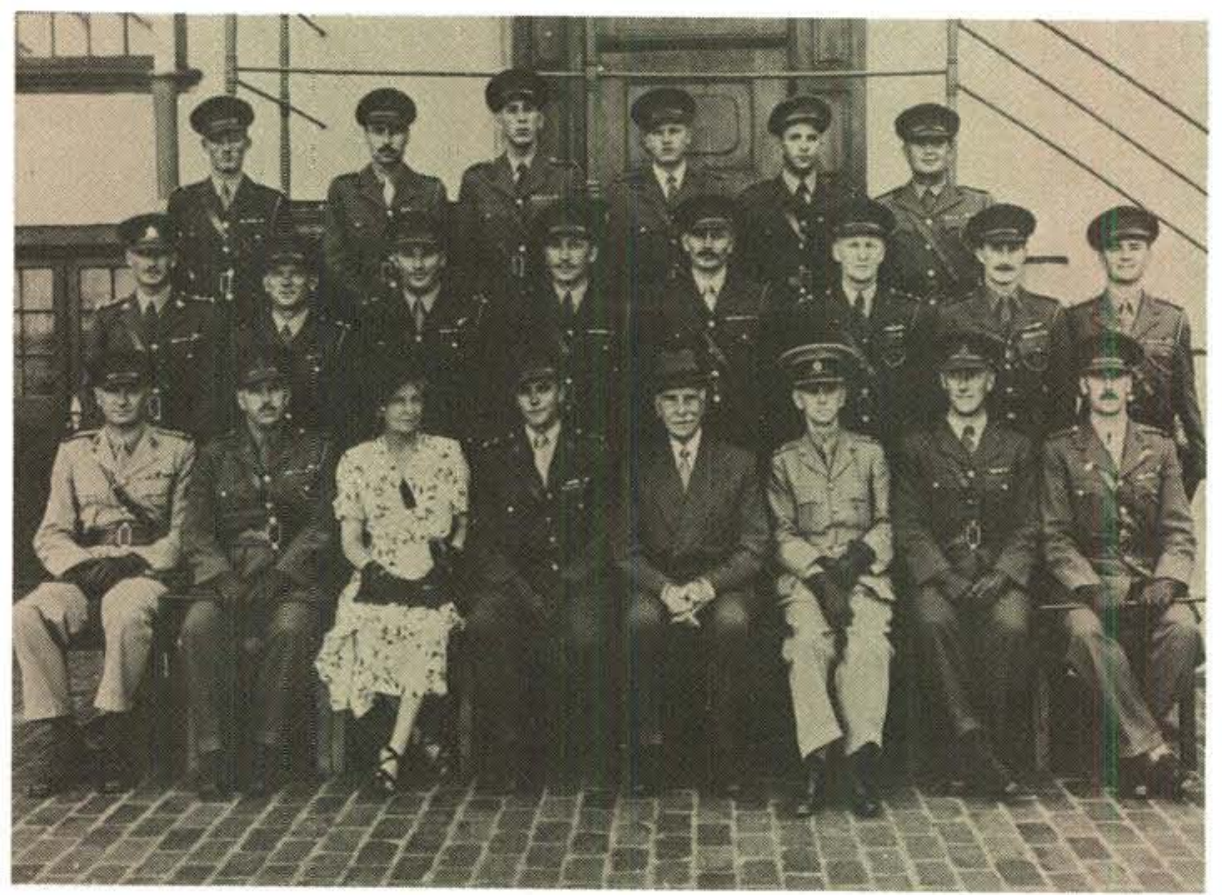

Although a number of members of the British Royal Family have visited the Castle few photographs of them here have survived. This one shows HRH Princess Alice, granddaughter of Queen Victoria, and Major General the Earl of Athlone, brother of Queen Mary and Colonel in Chief of the Duke of Edinburgh's Own Rifles with the Officers of the Regiment on 24 January 1948.

Hoewel 'n aantal lede van die Britse Koninklike familie die Kasteel besoek het, het slegs 'n paar foto's daarvan behoue gebly. Hier sit haar Majesteit

Prinses Alice, kleindogter van Koningin Victoria; genl-maj die Graaf van Athlone, broer van Koningin Mary en hoof van die Duke of Edinburgh's Own Rifles saam met die offisiere van die Regiment (24 Jan 1948).

Field Marshall Viscount Montgomery of El Alamein gave a lecture at the Castle in December 1947. On his right is the Deputy Chief of the General Staff, Major General W.H.E. Poole, behind them are the Officer Commanding Cape Command, Colonel Maurice de Villiers and Major P. Fourie.

\section{Veldmaarskalk Burggraaf Montgomery} van El Alamein het in Desember 1947 'n lesing by die Kasteel gegee. Regs van hom is die Adjunk-Hoof van die Generale Staf, genl-maj W.H.E. Poole. Agter hom is die Bevelvoerder van die Kaapse Kommandement, kol Maurice de Villiers en maj $P$. Fourie.

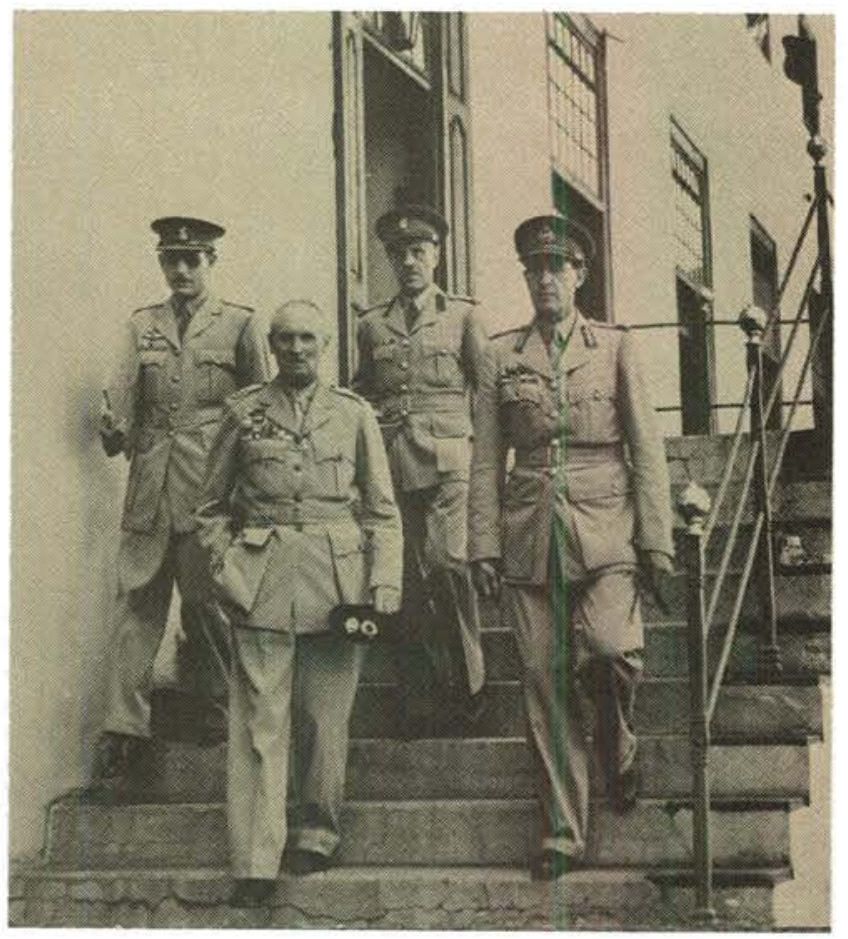




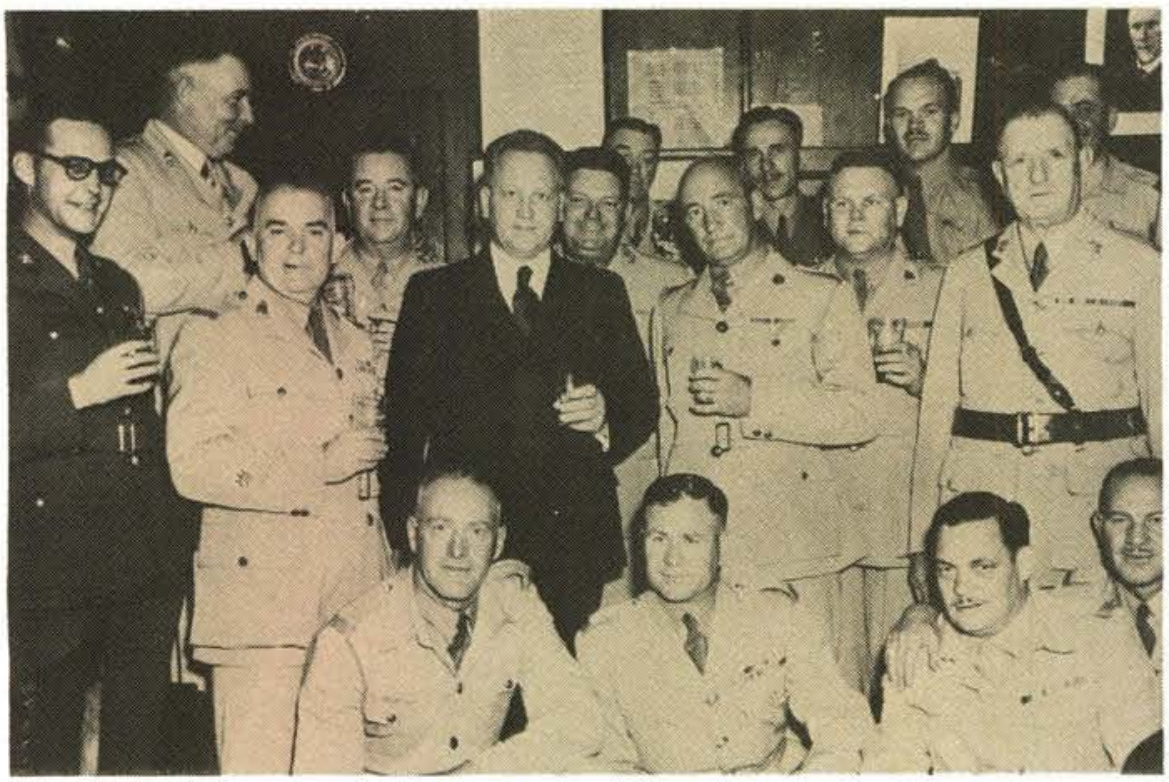

Sy Edele F.C.

Erasmus, Minister van Verdediging (1948-59) saam met adjudantoffisiere en senior onderoffisiere in die

Offisiersmenasie by die Kasteel in 1948.

The Hon F.C. Erasmus, Minister of Defence 1948-59 with Warrant Officers and senior Non-Commissioned Officers in the Non-Commissioned Officers' Mess at the Castle in 1948.

One of the founder members of the Union Defence Forces, Maj the Hon Piet van der Bijl, MC, acknowledges the salute of a contingent from the University of Cape Town of which he was the first Honorary Colonel from 1967-75.

Maj Piet van der Byl, MC, een van die stigterslede van die Unie Verdedigingsmag erken die saluut van 'n kontingent van die Universiteit van Kaapstad waarvan hy die eerste ere-kolonel was van 1967-75.
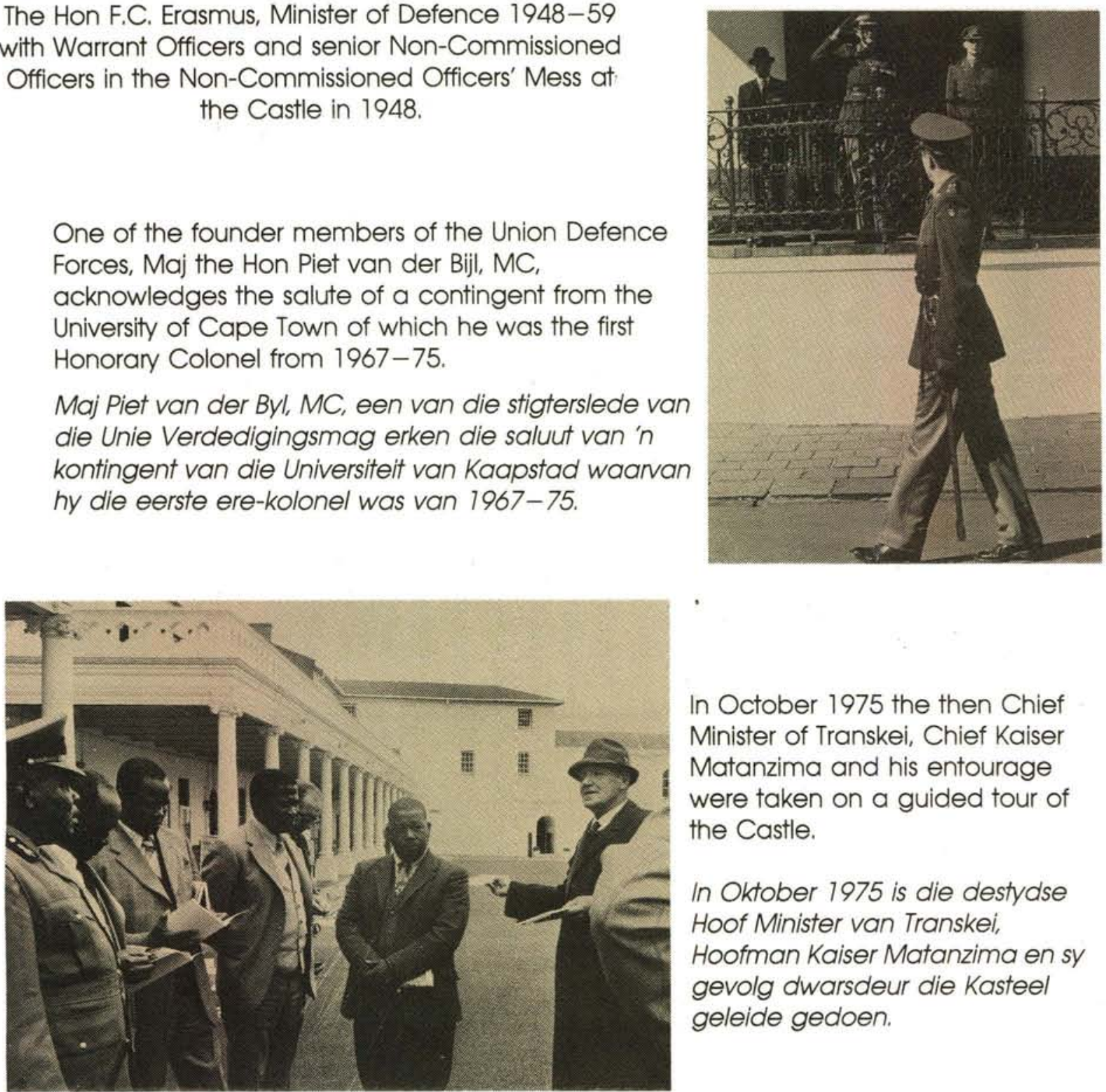

In October 1975 the then Chief Minister of Transkei, Chief Kaiser Matanzima and his entourage were taken on a guided tour of the Castle.

In Oktober 1975 is die destydse Hoof Minister van Transkei, Hoofman Kaiser Matanzima en sy gevolg dwarsdeur die Kasteel geleide gedoen. 


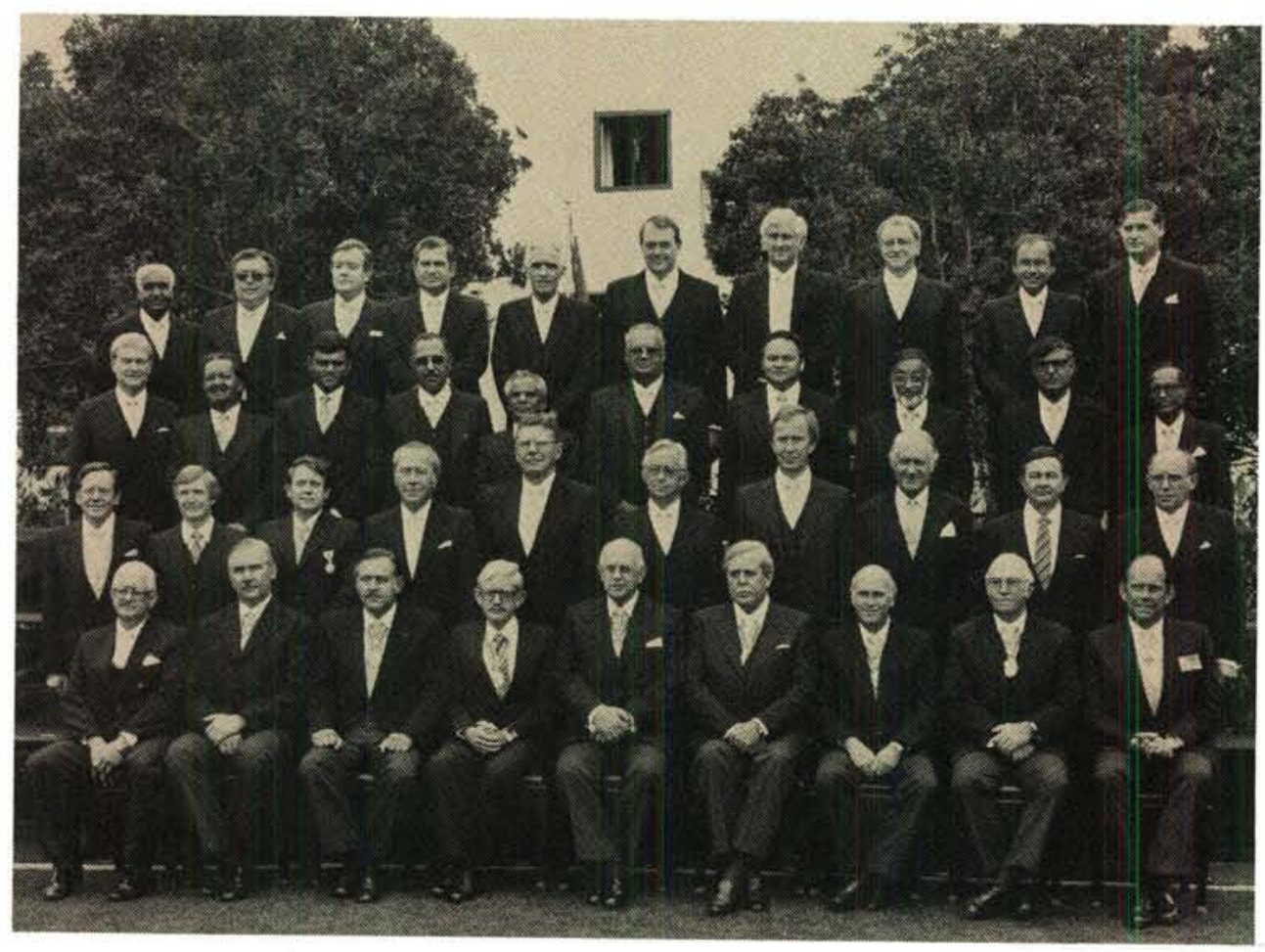

The first multi-racial Cabinet under the new constitution (8th Parliament) pose with the State President, Mr P.W. Botha, after being sworn in at the Castle, 17 September 1984.
Die eerste veelrassige Kabinet in die nuwe bedeling (8ste Parlement) saam met die Staatspresident, mnr P.W. Botha, nadat hulle op 17 September 1984 by die Kasteel ingesweer is.
The signing of the Cahora Bassa

agreement at the Castle on 2 May 1984. From left to right are seen Portuguese Foreign Minister Dr Jaime Gama, SA Minister of Foreign Affairs, Mr Pik Botha and Mozambican Minister of Planning, Mr Mario Machungo. The agreement was signed to resume water supplies from the Cahora Bassa hydro-electric scheme to South Africa.

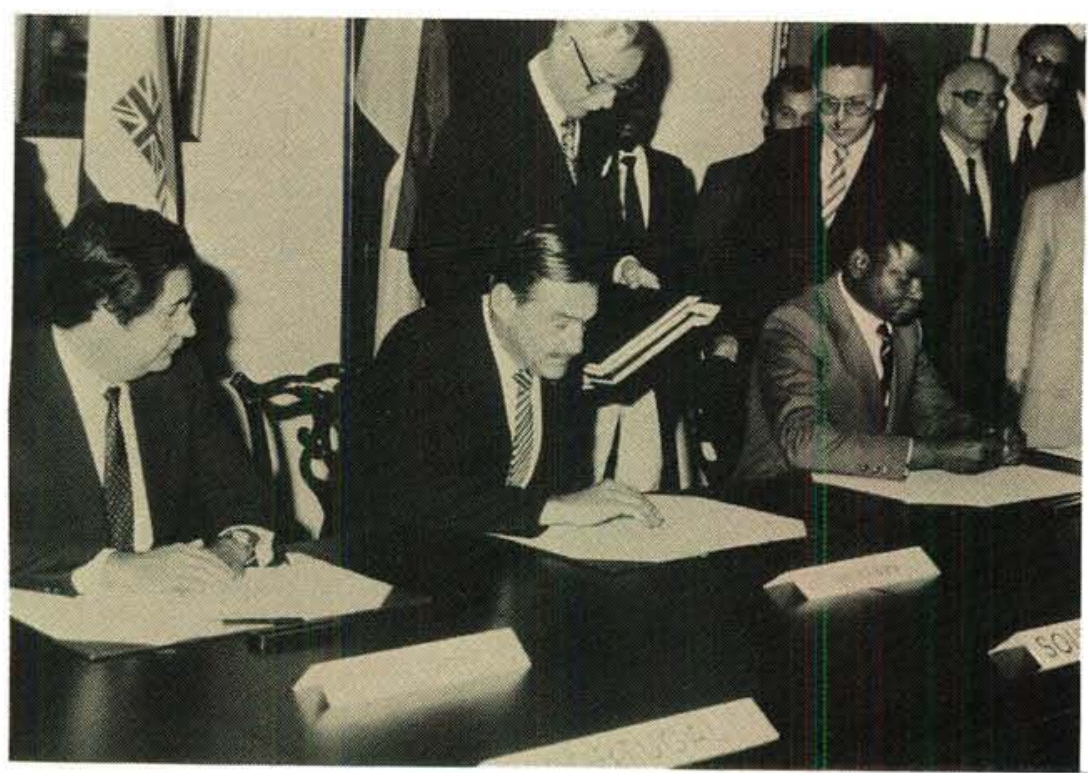

Die ondertekening van die Cahora Bassa ooreenkoms by die Kasteel op $2 \mathrm{Mei}$ 1984. Van links na regs is Portuguese Buitelandse Minister dr Jaime Gama, SA Minister van Buitelandse Sake, mnr Pik

Botha en Mosambiekse Minister van Beplanning, mnr Mario Machungo. Die ooreenkomste is onderteken om die voorsiening van water vanaf die Cahora Bassa hidro-elektriese skema na SuidAfrika voort te sit. 


\section{The No. 1 Military District and Cape Command Visitors' Books 1919-1957}

Cdr W.M. Bisset

Although the Castle of Good Hope in Cape Town is South Africa's oldest and most important building, a history of it, covering the period from 1713 until the present, has yet to be written. The recent chance discovery of the Visitors' Books of the British General Officer Commanding South African Military Command and his South African successor, the Officer Commanding No 1 Military District (Cape Command from 1934), is consequently of considerable importance. The two books cover the period from 29 May 1919 until 8 October 1957 and are probably the only conclusive evidence that those whose signatures they contain, were at the Castle in Cape Town on the dates recorded opposite their names.

Although most of the British Garrison left South Africa soon after the outbreak of the
First World War, the Union Government did not assume full responsibility for the country's landward defence until 1921 when transfer of the Castle and other British War Department property was given and taken. The British General Officer Commanding's Visitors' Book was left for his South African successor who continued to use it until 22 November 1937. Then, although the book was at that stage by no means full, it was replaced by a new UDF looseleaf book with three bilingual column headings: date, name and address. Each page was now a DD.33 form.

Although they are visitors' books, it does not necessarily follow that all those whose signatures they contain were seen by the Officer Commanding of the day. Visiting officers (including Active Citizen Force officers) from

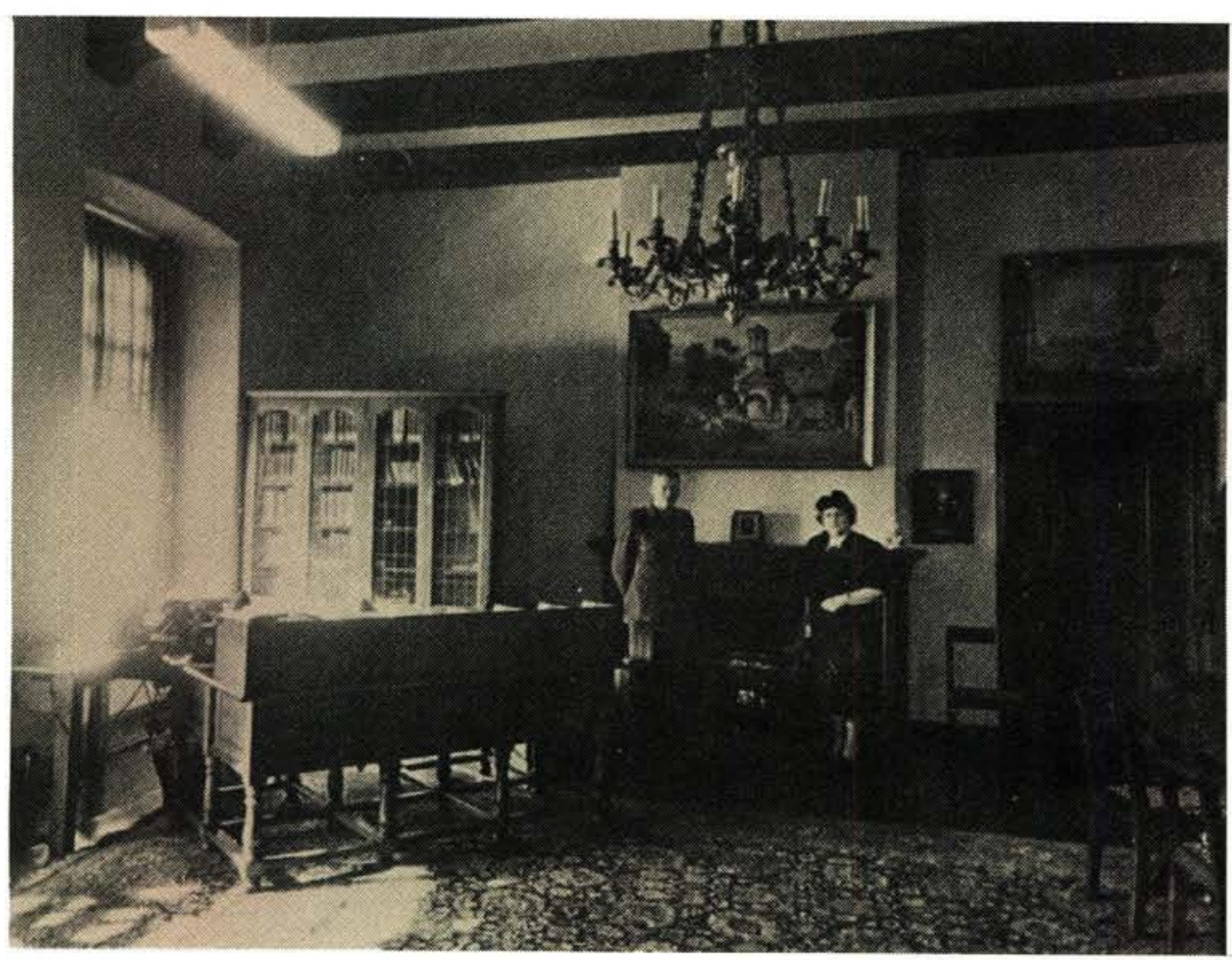

The Fortress Commander, Brig C.E. Borain, DSO, MC,

VD, ED and Mrs Borain in his office in the Castle circa 
out of town or other commands were expected, as a matter of courtesy, to call at the local Command Headquarters. If it was not possible for the Officer Commanding to see the officer, the fact that he had called and signed the Visitors' Book or left his card would suffice.'

These books contain the signatures of most, but by no means all of the distinguished visitors to the Castle during the period they cover. Although some of the signatures are impossible to decipher, I have nonetheless satisfied myself that they do not contain the signatures of HM King George II of the Hellenes who visited the Castle during the Secand World War or those of Their Majesties, King George VI and Queen Elizabeth, who were guests of Brigadier H.G. Willmott during the Royal Tour of 1947 and planted trees in the outer courtyard of the Castle. ${ }^{2}$ The signature of the Turkish Army Captain who served at the Castle during the Second World War can also not be found. ${ }^{3}$

The Visitors' Books do not reflect the names of those who visited the three ACF Officers' Messes within its walls (namely the Duke of Edinburgh's Own Rifles, Cape Field Artillery and Cape Town Highlanders) and the Wardroom of the RNVR Base between the Leerdam and Oranje bastions.

Nonetheless, the books contain enough legible signatures and other details to enable a researcher to compile statistics which would reveal fairly precisely just how many distinguished civilians, South African officers, British and foreign officers and other ranks signed the books.

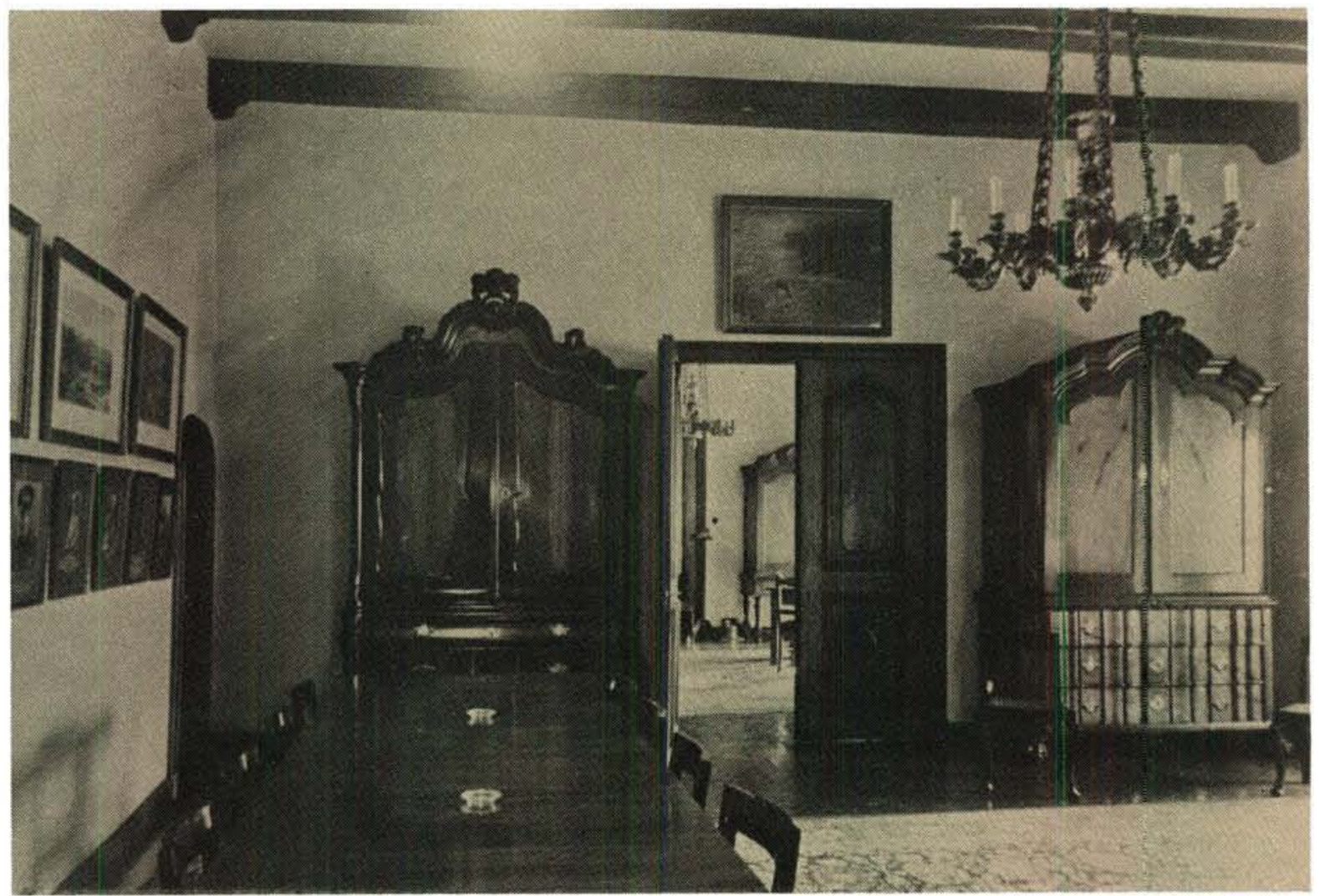

Another view of the Fortress Commander's office. 
Contained within the Visitors' Books are the signatures of almost every South African officer of note during the period they cover. Indeed, it would be easier to say whose signatures are missing. For this reason most of the South African officers' signatures have not been listed below. In some instances one can follow their progress from cadet to general. And there are reminders that some Permanent Force officers holding temporary wartime ranks reverted to their substantive ranks after the war. Brigadier Pieter de Waal was a temporary major general when he visited the Castle on 17 September 1946.

Some of the best known South African officers whose signatures are to be found in the books are Major General Sir Henry Lukin and his brother-in-law, Major General J.J. Collyer, General Sir Pierre van Ryneveld, Lieutenant Generals L. Beyers and C.L. de Wet du Toit, Commandant Generals S.A. Melville and R.C. Hiemstra and Admiral H.H. Biermann.
Although no Officer Commanding or Fortress Commander (the wartime designation) signed his own Visitors' Book, almost all of them did so before or after their period of command and this gives the books an added interest. The Castle was a place to which they would frequently return after a tour of duty in a war zone, elsewhere in South Africa or overseas and even after their retirement.

Space does not permit the publication of all the signatures in the two books. Some, as previously mentioned, are illegible and many would be of little interest. Since the significance of the details recorded in the books may not always be apparent to the reader, an additional column has been added which records the visitor's present occupation, post, rank or title or subsequent rank or title. Most of this information was found in the British Who's Who. In a number of instances the visitor has omitted the date.

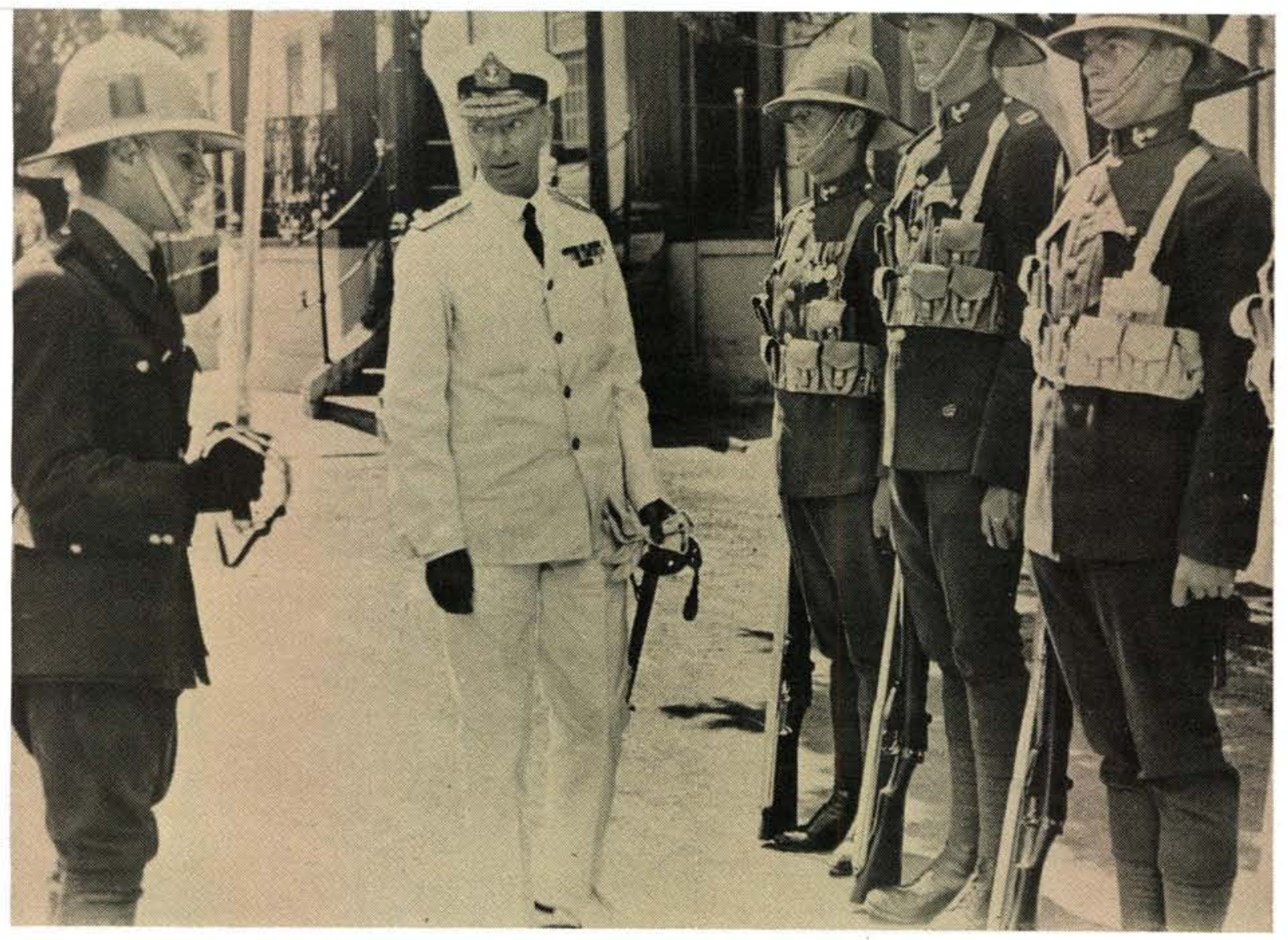

R Adm R.M. Burmester the RN Africa Station

Commander-in-Chief inspecting a SAPGA guard of honour at the Castle on 20 February 1929. 
These are indicated by a question mark after the date of the previous entry.

The kindness of Mrs W.H.E. Poole, Mr F.M. de Villiers and $\mathrm{Mr} \mathrm{C}$. Borain in donating the photographs which illustrate this article is gratefully acknowledged. The Military Information Bureau is deeply indebted to Cpl J.A. de Lannoy Copping who discovered the two Visitors' Books and realised their importance.

- Car W.M. Bissett is SOI SADF Museums Service

\section{References}

1. Cdr S.H.C. Payne, SA Nay Junior Officer's Handbook Durban 1955, p 13.

2. Interview with Maj Genl H.G. Willmott, CBE.

3. Notes by Mr R.K. Hallack. 


\section{Some of the Visitors' Book Entries}

Date

$24 / 2 / 20$

18.5.20

23 August 1920

27.8.20

10 th Sept

27.7.21

$1.10 .21(?)$

29.1.25

27.3.25

30.4 .25

21.1 .26

Nov 926

29.12 .27

Feb 201929

13 May 1929

16.4.30

16.4.30(?)

18.3 .33

$3 / 4 / 34$

16.5 .35

16 Aug 1935

27.8.35

5.11 .37

15 Aug 38

15 Aug 38(?)

16.3.39

26.5.39

15.8.39(?)

6.12 .39

7.3.40(?)

13 March 40

18.3.1940

17.7 .40

30.8 .40

$9.12 .40(?)$

14.3 .41

2.4 .41

23.iv.41

9.9 .41

9.10 .41

28.11 .41

27.xi.41

6.12 .41

$26 / 1 / 42$

$26 / 1 / 42$
Name

Flight Lt A. Beauchamp-Proctor, RAF

Lieut C.G. Finch-Davies, SAMR

The American Consul General

Vice Adml Sir W. Goodenough

Major R. Sinclair, RMLI

Louis Botha Capt (Disso's office)

Gen Sir G.F. Milne

Commander T.S.V. Phillips

F.M. Sir A. Barrett

Captain H.W.W. Hope, RN

Commander R.L. Burnett, Royal Nay

Colonel Sir Vernon G.W. Kell

Field Marshal Viscount Allenby

Rear Admiral R.M. Burmester

Captain L.C. Hollis, Royal Marines

P.O. Saver

J.G. Strijdom

Vice Admiral E.R.G.R. Evans

General Sir Alexander Godley

G. Brand van Zy!

Col F.H.P. Cresswell

Captain E.C. Mansergh

Sub Lt J.D. Nettleton, RNVR

Patrick Duncan

Alice Duncan

Lt Col H.T. Newman, Royal Marines

Devonshire

John, Cape Town

W. Brinton

Professor Edward Roworth

Captain B.C.S. Martin, RN

General Sir Archibald Wovell

\section{Lt Col E.R.C. Ames}

Capt Leif Egeland

Sir Stewart Symes

Lt Col B.J. Schonland

Air Vice Marshal C. Pulford, RAF

Capt J.T. Borrett, RN

Consul General for Czechoslovakia and Madam Blahovska

General Sir James Marshall-Cornwall

R.G. Lewis Maj Gen

Dr S. Guvrilovic

J.F. Evetts Major General

Brigadier C.A. Lyon

R. Brooke-Popham
Address

Civil Service Club, Cape Town

The Castle

rank, occupation, etc.

Mount Nelson Hotel

C-in-C Africa

Clocktower, Docks, Cape Town

District Staff Office Cape Town

England

HMS VERBENA

Shambrook, Beds, England

HMS REPULSE

HMS WALLFLOWER

War Office, London

Rust en Vrede, Muizenberg (Home of Sir Abe Bailey)

C-in-C Africa Station

The Pebble, Seaforth, Simonstown

Stellenbosch

Nylstroom

Admiralty House, Simonstown

\section{Guards' Club}

Normanhurst, Sea Point

Kuils River

Royal Artillery, R.M. Academy,

Woolwich

The Castle, CT

Government House

Government House

The Castle

Bishopscourt, Claremont

Mayor Cape Town

Directors' House, National Gallery

HMS DORSETSHIRE

GHQ, Middel East, Cairo

\section{OC Troops, MAURETANIA}

House of Assembly, Cape Town

Mt Nelson Hotel

International Hotel from $\mathrm{DHQ}$

Hd Qtr RAF Singapore

\section{HMS SHROPSHIRE}

"Humbleback" cor Tennant Rd and Lovers Walk Wynberg

GO C-in-C British Troops in Egypt

War Office London

Yugoslav Consul General

Army and Novy Club, London

HMT

HMT
VC, DSO, MC and Bar, DFC

Eminent bird illustrator

Son of Gen Louis Botha Later'Field Marshal, Lord and CIGS

Later Admiral

Field Marshal

Later Admiral

C-in-C, South Atlantic

1944-46

Head of M15

Later Admiral

Later General

Later Cabinet Minister

Later Prime Minister

Later Admiral Lord

Mountevans

Later Governor-General

Minister of Defence 1924-33

Born in SA. Later General,

$\mathrm{GCB}, \mathrm{KBE}, \mathrm{MC}$

Later Wing Codr. Awarded the VC

H.E. the Governor-General

Lady Duncan

Seconded UDF 1939-42, later Maj Genl

His Grace the Duke of Devonshire, GCVO

Anglican Archbishop

Artist

Later Vice-Admiral

Later Field Marshal, Earl,

Viceroy of India

MP and later High

Commissioner

Governor-General of the

Sudan

Eminent scientist

Air Officer Commanding, Far East

\section{DQMG}

Asst CIGS 1942

Air Chief Marshal Sir, C-in-C Far East 1940-1941 


\begin{tabular}{|c|c|c|c|}
\hline Date & Name & Address & $\begin{array}{l}\text { Present or subsequent post, } \\
\text { rank, occupation, etc. }\end{array}$ \\
\hline 7.3 .42 & $\begin{array}{l}\text { Maj Gen Sir J. and Lady Scobell and } \\
\text { Miss Scobell }\end{array}$ & Passing through & $\begin{array}{l}\text { Commanding troops Malta } \\
1939-42\end{array}$ \\
\hline $18 / 6 / 42$ & Sir E.J. Harding & High Commissioner's Office & $\begin{array}{l}\text { CT representative of British } \\
\text { High Commissioner 1942-44 }\end{array}$ \\
\hline 19.10 .42 & Charles N.R. Brown Lieut General & Passing through & \\
\hline 19.10 .42 & Colonel J.G. Smyth & Passing through & Brigadier, VC, Bart, MP \\
\hline 27.10 .42 & $\begin{array}{l}\text { Baron Morund Fighting French } \\
\text { Delegate }\end{array}$ & Ivan's Hotel, Sea Point & \\
\hline 28.10 .42 & R.G. Sturges Maj Gen & London & Later Lt Genl \\
\hline 12.1 .43 & Capt J.C. Smuts SAEC & Groote Schuur, Rondebosch & Son of Gen Smuts \\
\hline 17.2 .43 & Mrs Dan Pienaar & Pretoria & $\begin{array}{l}\text { Widow of Maj Gen D.H. } \\
\text { Pienaar, CB, DSO }\end{array}$ \\
\hline 6.4 .43 & Read Admiral C.N. Reyne & Transit & Convoy Commodore \\
\hline 15.9 .43 & C.W. Meredith AVM & Salisbury & Air Vice Marshal, KBE \\
\hline $21 / 2 / 44$ & B.E. Skyrme $2 / O$ & SANF HQ Cape Town & Only SWANS officer \\
\hline $4 / 3 / 44$ & Noel Coward & London & Actor and playwright \\
\hline 17.4 .44 & B.F. Giles Brig Gen USA & USAFIME & \\
\hline 10.6.44 & G.S. Ashley Comdr USNR & US Naval Attache & \\
\hline 30.8 .44 & Marie Ney & London & $\begin{array}{l}\text { Actress Producer with SABC } \\
1942-44\end{array}$ \\
\hline 3.11 .44 & Keith Park & HQ RAF Cairo & $\begin{array}{l}\text { Air Chief Marshal AOC-in-C } \\
1944\end{array}$ \\
\hline 27.12 .44 & L.T. Burrage Lt & 2 Clifton Ct, Victoria Rd, Clifton & South African war artist \\
\hline 10.2 .45 & C. van Riet Lowe & Historical Monuments Commission & \\
\hline 16 February & Vice Admiral Sir Campbell Tait & Salisbury, Southern Rhodesia & Governor and C-in-C \\
\hline 22.2 .45 & T.J. Kelly AVM RAF & $\mathrm{HQ}$ RAF Italy & $\begin{array}{l}\text { PMO Mediterranean and } \\
\text { Middle East } 1944-46\end{array}$ \\
\hline 14.3 .45 & Lady Mary Baring & High Commission House & Wife of H.C. \\
\hline 14.3 .45 & Mrs F.O. Stohr (Elsie Hall) & Victoria House, Rondebosch & Pianist \\
\hline 16.3 .45 & R.M. Deshmukh & High Commissioner for India & \\
\hline 18.5 .45 & $\begin{array}{l}\text { H. Earle Russell, American Consul } \\
\text { General }\end{array}$ & Cape Times Bldg & \\
\hline June 51945 & Geo B. MCManus Commander USNR & US Naval Attache Cape Town & \\
\hline 18th August & Harry Lawrence & Union Buildings, Pretoria & Cabinet Minister \\
\hline 3.9 .45 & A.W. Tedder Air Chief Marshal & England & $\begin{array}{l}\text { Marshal of the RAF Lord, } \\
\text { Depuly Supreme Commander } \\
\text { AEF Western Europe 1943-45 }\end{array}$ \\
\hline 3.9 .45 & Marie Tedder & England & Lady Tedder \\
\hline 6.9 .45 & Maj J.A.l. Agar-Hamilton & GHQ Pretoria & War historian \\
\hline 27th Nov & Leathers & London & $\begin{array}{l}\text { Lord, PC, CH, British Minister of } \\
\text { War Transport } 1941-45\end{array}$ \\
\hline 16 Jul 46 & Lieut Commander P.J. Hill-Norton RN & HMS NIGERIA, Simonstown & Admiral of the Fleet, Lord \\
\hline 20.9 .46 & A. de Rooy Captain R Neth $\mathrm{N}$ & HNMS KAREL DOORMAN & \\
\hline $20.9 .46(?)$ & M. Visser, Netherlands Minister & & \\
\hline 21.9 .46 & Major and Mrs Francis Brett-Young & 'Alacen', Leighton Road, St James & Author \\
\hline 12.11 .46 & Harry Smith, Capt US Navy & US Naval Attache & \\
\hline 26.9 .47 & G.D. Lestrade Commander & Argentine Training Ship & PUEYRREDON \\
\hline $3 . x i .47$ & General Sir Walter Kirke & Admiralty Lodge Simonstown & IG British Home Defences 1939 \\
\hline 27.11 .47 & Montgomery of Alamein Field' Marshal & CIGS & \\
\hline 29.12 .47 & Vasco Lopes Alves & NRP AFONSO DE ALBUQUERQUE & \\
\hline 16 Oct 1948 & James H. Fiskett, Rear Admiral & US Nay & \\
\hline 18 Oct 48 & M.J. Mansergh Rear Admiral & $\begin{array}{l}\text { Commanding 3rd Aircraft Carrier } \\
\text { Squadron }\end{array}$ & \\
\hline 22 Dec 48(?) & F.C. Erasmus & & Minister of Defence \\
\hline 29.12 .48 & E. Haimet & Consul for France & \\
\hline 16.9 .49 & Sir William and Lady Murphy & At Glen Dirk Constantia & $\begin{array}{l}\text { Governor and C-in-C, } \\
\text { Bahamas } 1945-49\end{array}$ \\
\hline $23 / 9 / 49$ & G.B. Parkinson Brig & New Zealand Military Forces & \\
\hline 1.2 .50 & Y. Ganlan, Consul for Israel & Hotel Genina, Sea Point & \\
\hline 28th April 1950 & Lieut General Sir Arthur A.B. Dowler & $\begin{array}{l}\text { GOC East Africa Command, } \\
\text { Kenya }\end{array}$ & \\
\hline
\end{tabular}




\begin{tabular}{|c|c|c|c|}
\hline Date & Name & Address & $\begin{array}{l}\text { Present or subsequent post, } \\
\text { rank, occupation, etc. }\end{array}$ \\
\hline 30th Sep 1950 & H.A. Packer & $\begin{array}{l}\text { Commander-in-Chief South } \\
\text { Atlantic }\end{array}$ & Admiral \\
\hline 5.1 .51 & $\begin{array}{l}\text { Captain di Vaisseau de Toulouse - } \\
\text { Lautier }\end{array}$ & Commandant la JEANNE D' ARC & \\
\hline 25.1 .51 & Abdelmegid Ahmed Saleh & Consul General for Egypt & \\
\hline 2 May 1951 & General Sir Brian Robertson & C-in-C GHQ MELF & Middle East Land Forces \\
\hline 5 April 1952 & E.G. Jansen & Goewerneurswoning & H.E. the Governor-General \\
\hline 3.5.55 & Wm Fehr & Kenilworth (Cape) & Antique collector \\
\hline 3.8 .55 & I.M.R. Campbell & C-in-C South Atlantic & Vice Adm, KBE \\
\hline 7.6 .56 & Geoffrey Robson & $\begin{array}{l}\text { Commander-in-Chief, South } \\
\text { Atlantic }\end{array}$ & Vice Admiral \\
\hline 2.10 .57 & Oliver Leese & $\begin{array}{l}\text { Lower Hall, Worfield Bridgnorth, } \\
\text { England }\end{array}$ & Lt Gen Sir \\
\hline
\end{tabular}




\section{Officers Commanding WP Command 1914-1981}

Officer

Designation of Post

Period of Command

Lt Col G. Hodgson, CBE

Col W.E.C. Tanner, CB, CMG, DSO

District Staff Officer, No 1 Military District

Lt Col F.S. Dawson, CMG, DSO \& Bar, ADC

4.9.1914-26.8.1919

Lt Col T.H. Blew, DSO

Brig Gen W.E.C. Tanner, CB, CMG, DSO

Col F.G. Harvey, CBE, DSO

Lt Col B.C. Judd, OBE

Col B.D. Bouwer, DTD, DSO

Lt Col H.S. Wakefield, OBE

Lt Col P. de Waal

Col G.E. Brink. DSO

Brig Gen K.R. van der Spuy, MC

Brig B.F. Armstrong

Lt Col H.E. Cilliers

Brig C.J. Venter, DFC

Brig Gen W.E.C. Tanner, CB, CMG, DSO

Brig W.H.E. Poole

Col A.H.K. Jopp, DSO

Brig C.E. Borain, DSO, MC, VD

Brig B.F. Armstrong, DSO

Brig H.G. Willmott, CBE

Brig M. de Villiers

Brig J. Daniel, CBE

Col L. du Toit

Col P.S. de Lange, MC

Col L.J. Klootwyk

Col G.N. Nauhaus. OBE

Col P.J. Jacobs, SM

Col G. Dunbar-Moodie

Col P.F. van der Hoven

Brig P.E. Ferguson, MC, ED

Brig P.F. van der Hoven

Brig J. Fourie, SM

T/Brig L.H. Robertson, SM

Brig J. Fourie, SM

T/Brig L.H. Robertson, SM

Brig M.A. de M. Malan, SM

Brig H. Roos

OC, No 1 Military District

$26.8 .1919-13.10 .1919$

$11.11 .1919-11.5 .1920$

$5.12 .1920-27.12 .1921$

$28.12 .1921-1.9 .1925$

$1.9 .1925-2.10 .1928$

$2.10 .1928-1.2 .1929$

$1.2 .1929-1.5 .1931$

1.5.1931-24.11.1932

OC. Cape Command

$24.11 .1932-7.12 .1933$

$13.12 .1933-31.1 .1937$

1.2.1937-2.10.1937

Acting OC, Cape Command

OC, Cape Command

2.4.1937-2.10.1937

3.10.1937-30.6.1939

Acting OC, Cape Command

OC, Cape Command

$1.7 .1939-12.7 .1939$

$13.7 .1939-4.11 .1940$

$1.11 .1940-30.6 .1942$

Commander, Cape Fortress

$1.7 .1942-6.8 .1942$

Acting Commander, Cape Fortress

Commander, Cape Fortress

oC Cape Command

$7.8 .1942-5.10 .1942$

$6 / 10.1942-29.5 .1945$

29.5.1945-11.7.1945

$12.7 .1945-15.10 .1946$

$16.10 .1946-18.9 .1947$

19.9.1947-26.1.1948

$27.1 .1948-13.12 .1950$

$14.12 .1950-21.4 .1955$

22.4.1955-12.12.1956

$15.12 .1956-7.11 .1958$

$8.11 .1958-11.1 .1960$

OC, WP Command $\quad 11.1 .1960-30.1 .1961$

$31.1 .1961-11.7 .1961$

12.7.1961-31.7.1963

$1.8 .1963-16.7 .1966$

$17.7 .1966-31.12 .1968$

$1.1 .1969-19.11 .1970$

Acting OC, WP Command

OC. WP Command

$19.11 .1970-18.7 .1971$

$19.7 .1971-3.1 .1972$

Acting OC, WP Command

OC. WP Command

$27.7 .1971-2.1 .1972$

4.1.1972-2.1.1973

$3.1 .1973-3.1 .1974$

4.1.1974-24.1.1980

24.1.1980-1985

Brig S.J. van der Spuy

Brig $Y$, de Bruyn 


\section{Functions held at the Castle} Official and Military

\section{Funksies gehou by die Kasteel}

\section{Amptelik en Militêr}

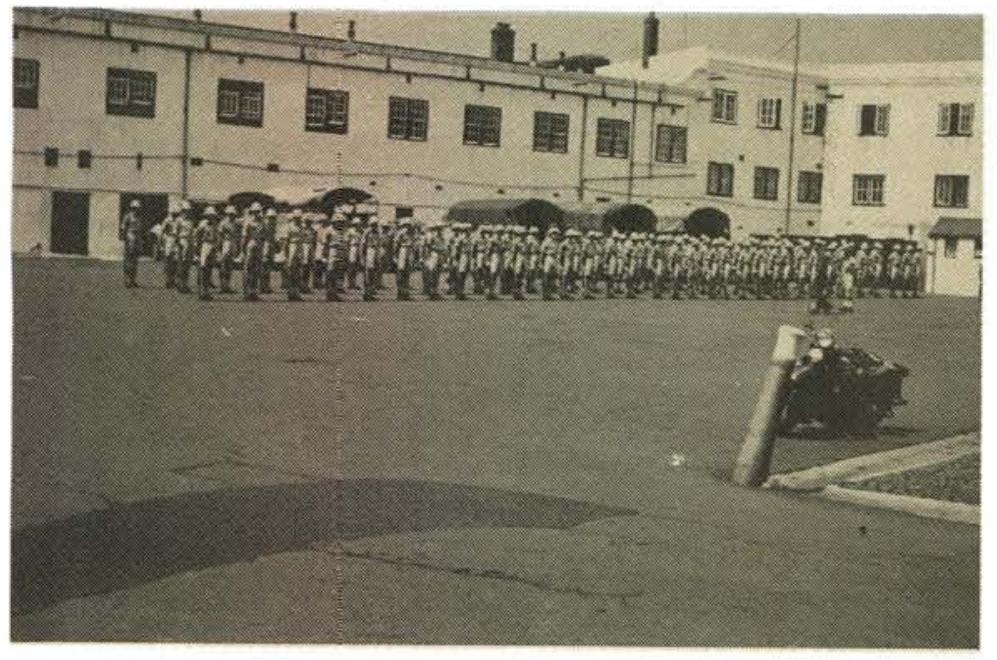

The Guard of Honour of 2

Battalion Railways and Harbours Brigade parade in the inner courtyard of the Castle prior to the opening of Parliament on 22 January 1950.

Die erewag van die $2 \mathrm{Bn}$ Spoonweg en Hawens brigade in die binnehof van die Kasteel voor die opening van die parlement op 20 Januarie 1950.

The State President's Guard march past the Commandant General SA Defence Force, General R.C. Hiemstra on 29 January 1969.

Die Staatspresidentswag marsjeer verby genl R.C. Hiemstra (Kmatt-genl SA Weermag) op 29 Januarie 1969.
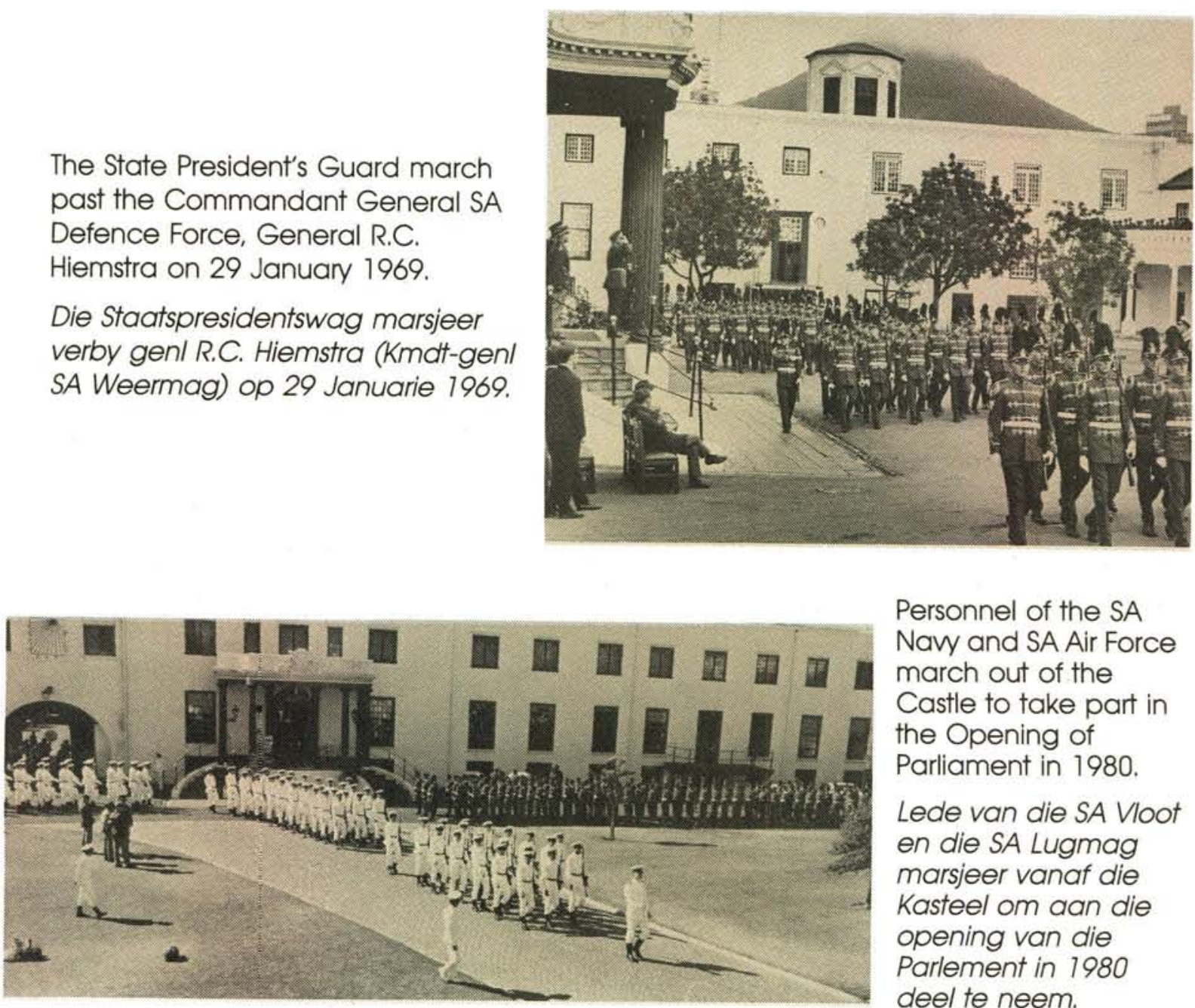

Personnel of the SA Nawy and SA Air Force march out of the Castle to take part in the Opening of Parliament in 1980. Lede van die SA Vloot en die SA Lugmag marsjeer vanaf die Kasteel om aan die opening van die Parlement in 1980 deel te neem. 
The Royal Marine Band followed by a SA Corps of Marines Guard of Honour marching out of the Castle on Coronation Day, 2 June 1953.

Die Koninklike Vlootorkes gevolg deur die $S A$

Vlooterewagkorps marsjeer op

Kroningsdag 2 April 1952 uit die Kasteel uit.
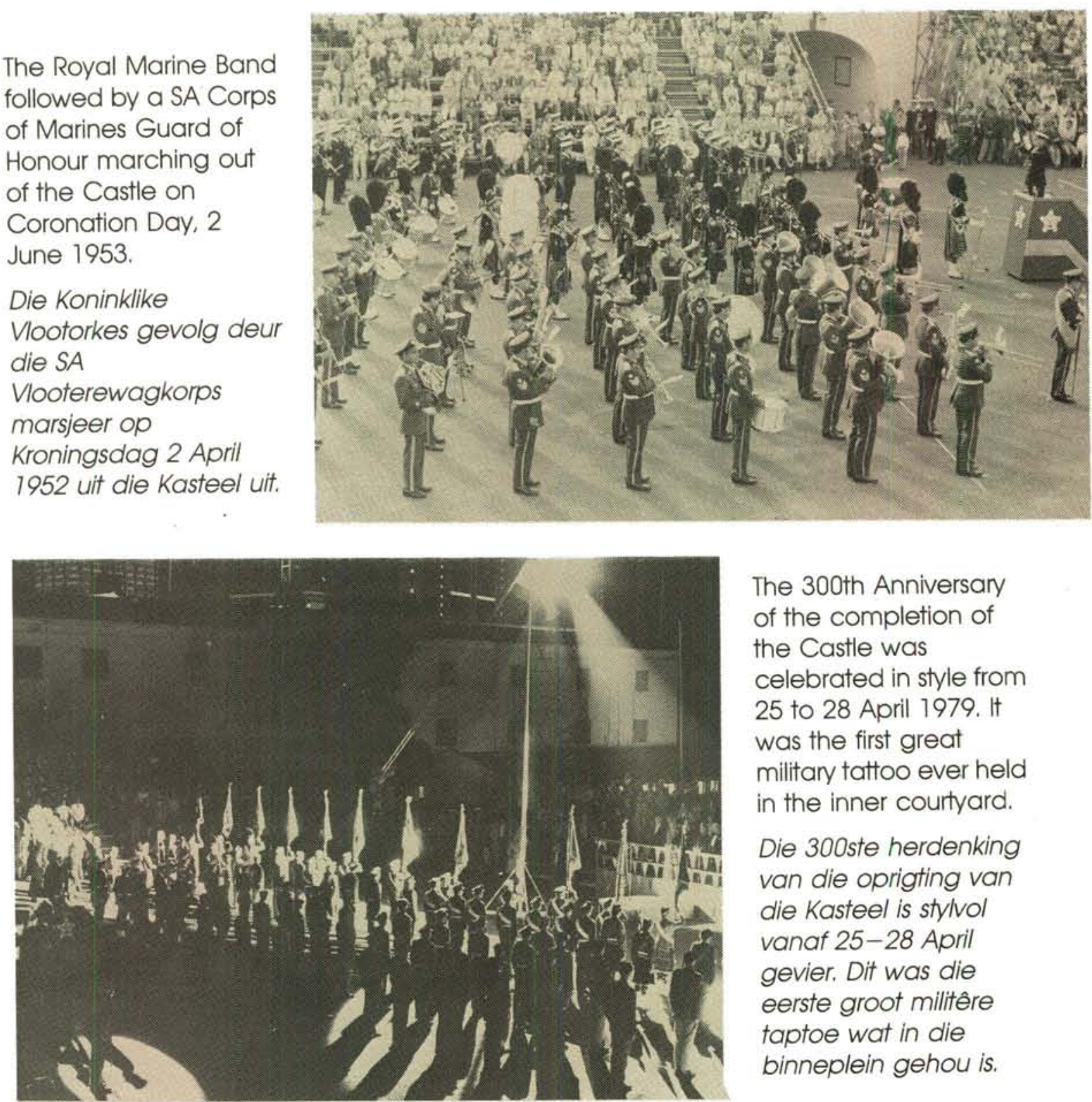

The 300th Anniversary of the completion of the Castle was celebrated in style from 25 to 28 April 1979. It was the first great military tattoo ever held in the inner courtyard.

Die 300ste herdenking van die oprigting van die Kasteel is stylvol vanaf 25-28 April gevier. Dit was die eerste groot militêre taptoe wat in die binneplein gehou is.

A view of the moving finale of the tattoo.

Die aangrypende finale van die taptoe.

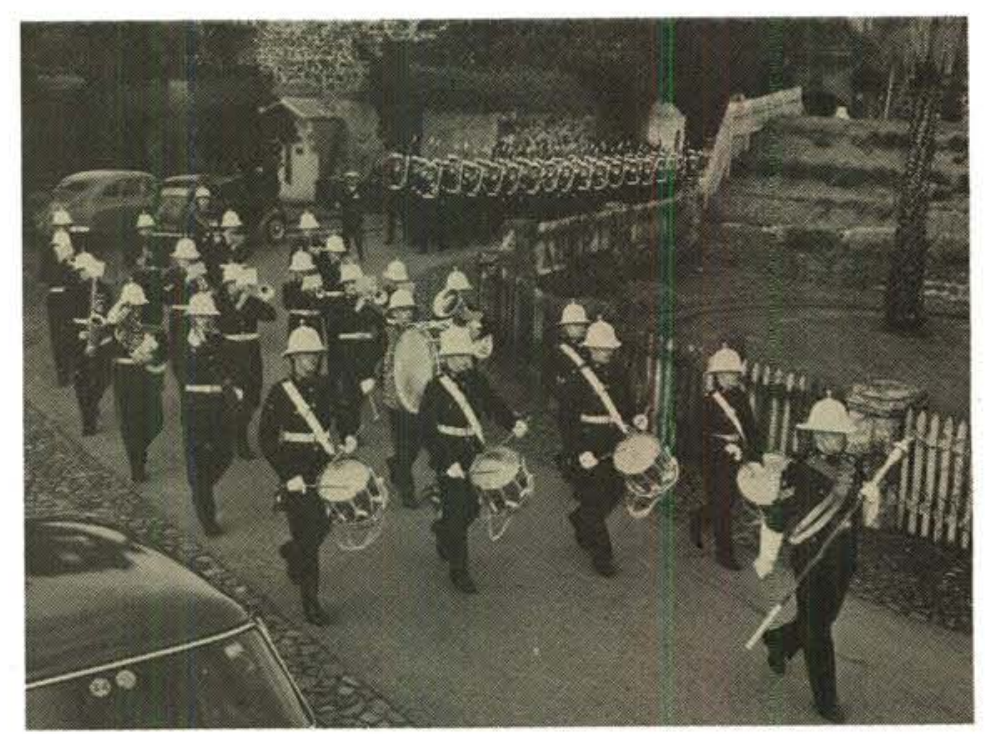



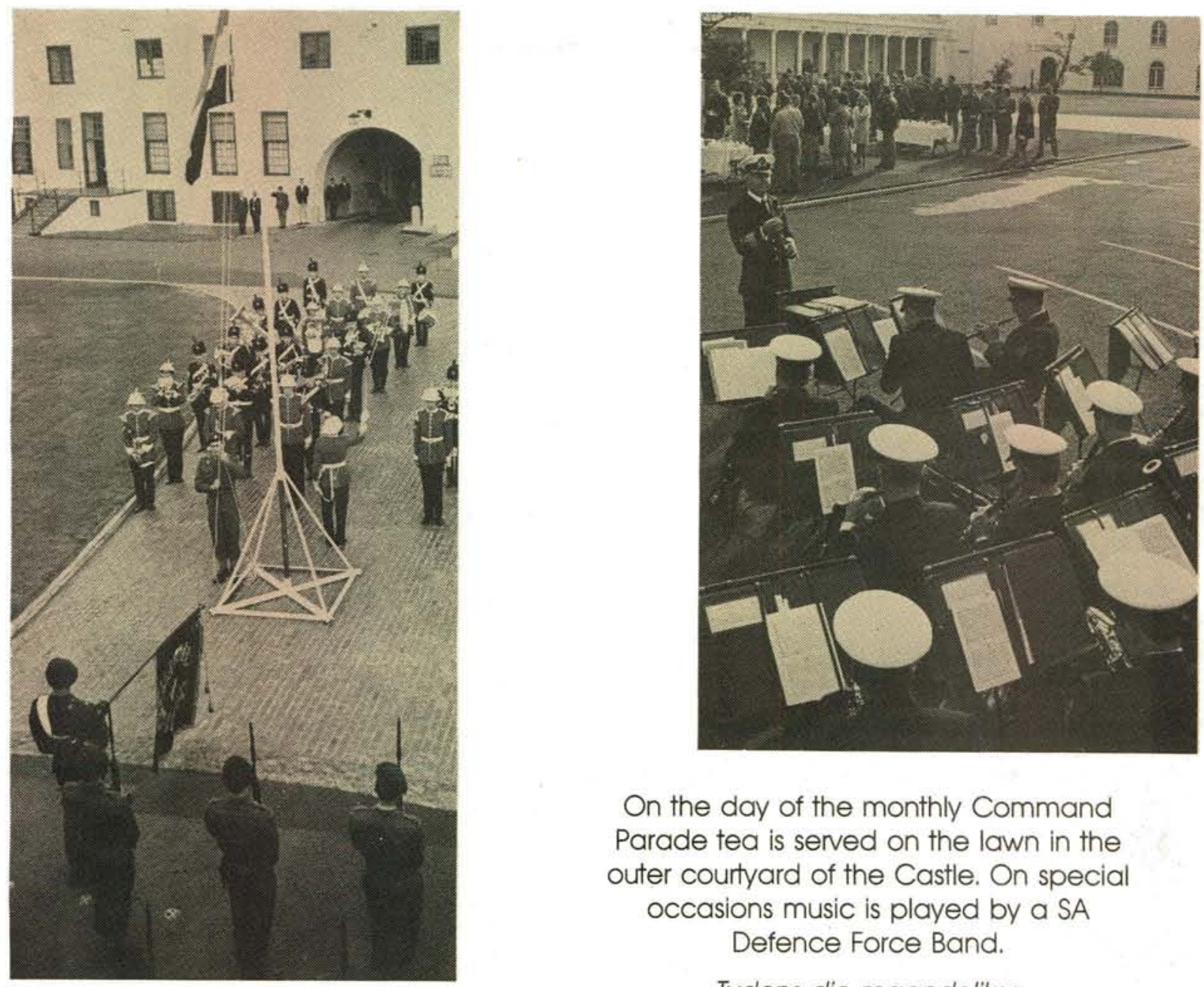

On the day of the monthly Command

Parade tea is served on the lawn in the outer courtyard of the Castle. On special occasions music is played by a SA Defence Force Band.

Tydens die maandelikse Kommandementsparade word tee op die grasperk van die Kasteel se binneplaas bedien. Met spesiale geleenthede tree die SA Weermagorkes op.

Many retreat ceremonies have been held at the Castle. On the photograph appear bands of the Cape Town Rifles (Dukes) and the Cape Field Artillery (26 May 1969).

By die Kasteel is baie vlaghysingseremonies gehou. Op die foto verskyn die orkeste van die Cape Town Rifles (Dukes) en die Cape Field Artillery (16 Mei 1969).

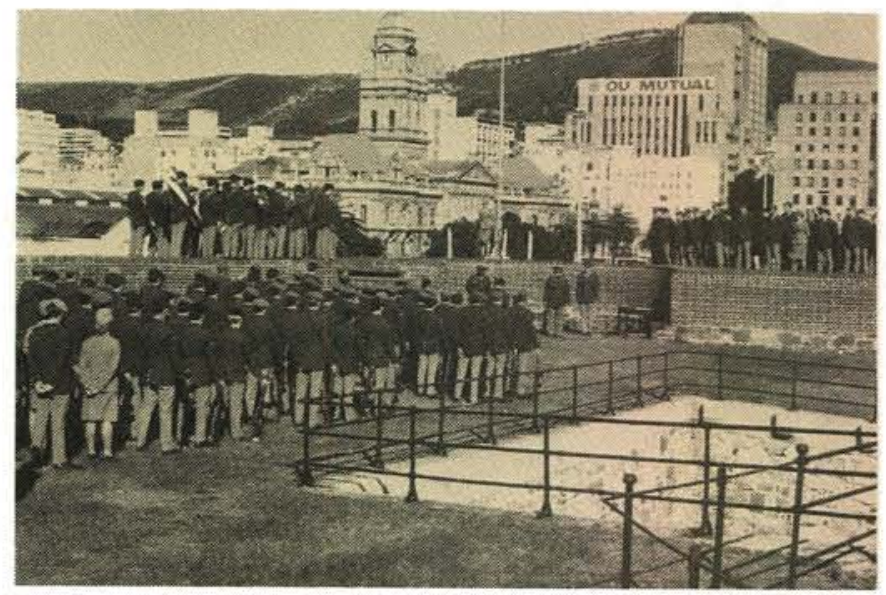

This Western Province Command monthly Command Parade was held on Leerdam Bastion in 1979.

Kmamt WP het hierdie Kommandementsparade in 1979, by die Leerdam bastion gehou. 


\section{Commemorative and social functions}

A happy photograph of what is believed to have been the last wedding reception held in the Lady Anne Barnard Ballroom. Colonel H.F. Prinsloo, OBE, ED, and Mrs Prinsloo are seen cutting their wedding cake watched by Colonel R.D. Pilkington Jordan.

in Gelukkige foto van moontlik die laaste huweliksonthaal wat in April 1945 in die Lady Anne Barnard Balsaal gehou is. Kol H.F. Prinsloo, $O B E, E D$, en mev Prinsloo is besig om hulle troukoek te sny, terwyl kol R.D. Pilkington Jordan toekyk.

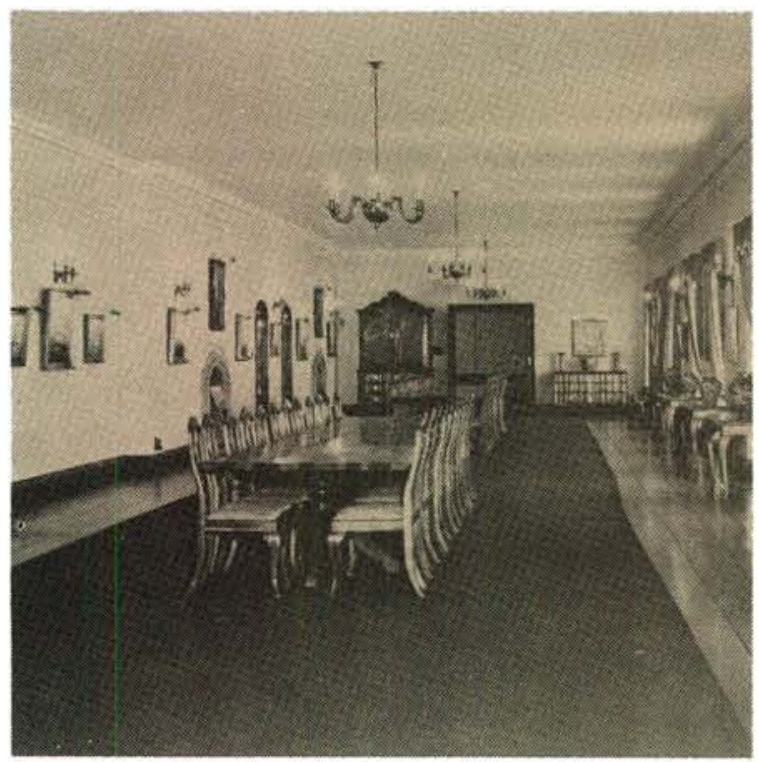

\section{Herdenkings en sosiale geleenthede}

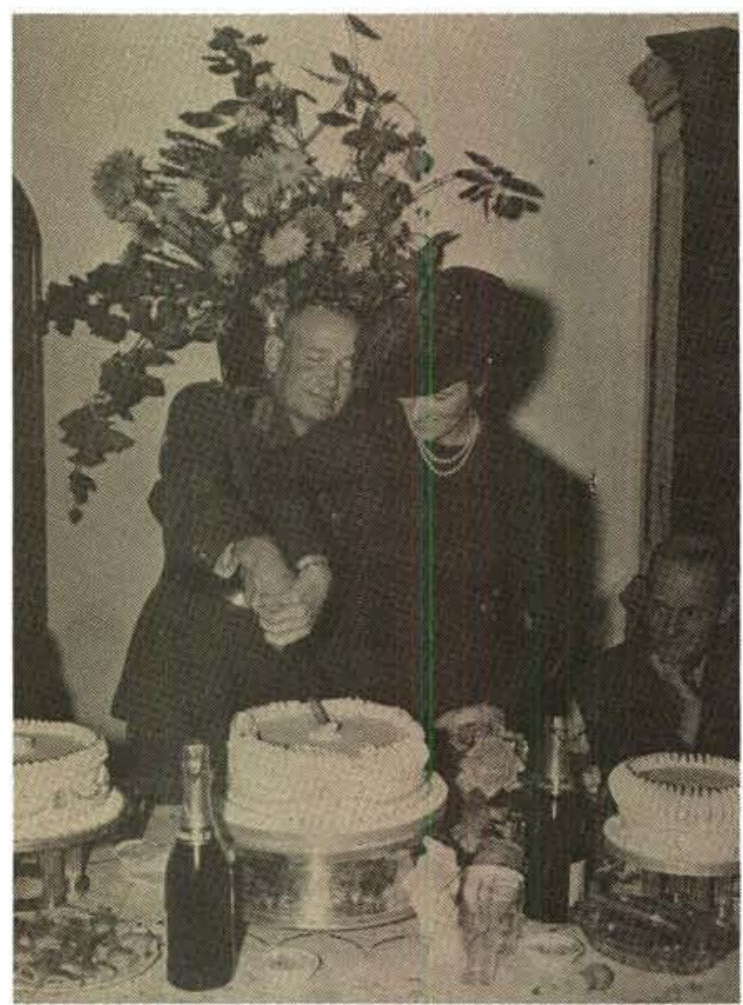

The Lady Anne Barnard Ballroom or Banqueting Room at the Castle is 180 feet long.

Die Lady Anne Barnard Bal- of Banketsaal by die Kasteel wat 180 voet lank is.

Major-General W.H.E. Poole (Depuly Chief of the General Staff) with Mrs J. Daniel at the first dance held in the Lady Anne Barnard Ballroom after the Second World War in March 1948.

Genl-maj W.H.E. Poole (Adjunk Hoof van die Generale Staf), saam met mev J. Daniel, by die eerste dans wat na die Tweede Wêreldoorlog in die Lady Anne Barnard Balsaal gehou is.

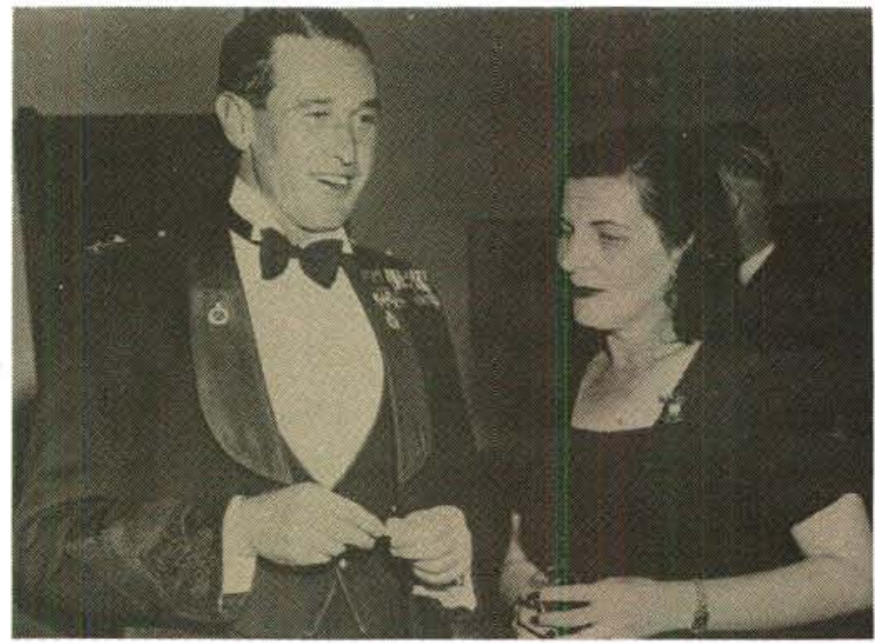




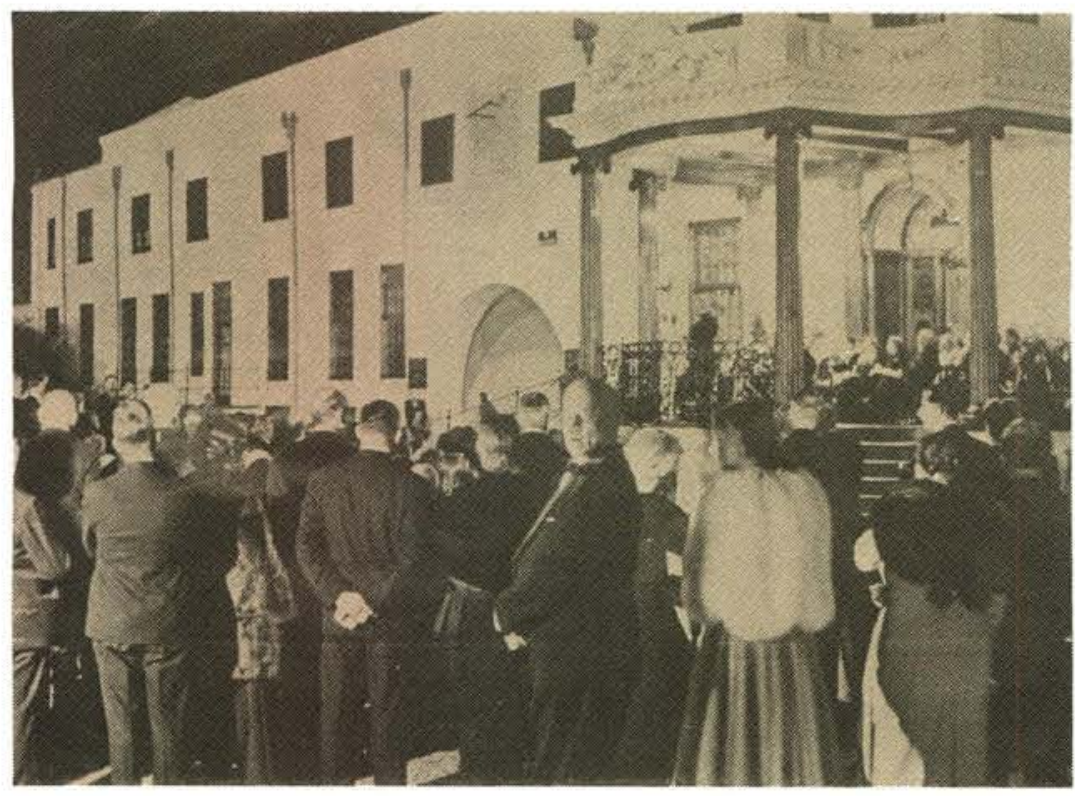

On 20th February 1952

the Governor General Dr E.G. Jansen, opened the Van Riebeeck Festival of Art at the Castle.

\section{Die Goewerneur}

Generaal dr E.G. Jansen open op 20 Februarie 1952 die Van Riebeeck Kunsfees by die Kasteel.

Dr and Mrs William Fehr and their daughter at a buffet supper party at the Castle. Dr Fehr's collection of antiques was borrowed during the Van Riebeeck Festival in 1952 and purchased in 1964.

Dr en mev William Fehr en hulle dogter, tydens 'n buffetete by die Kasteel. Dr Fehr se versameling oudhede is met die Van Riebeeckfees in 1952 geleen en later aangekoop.
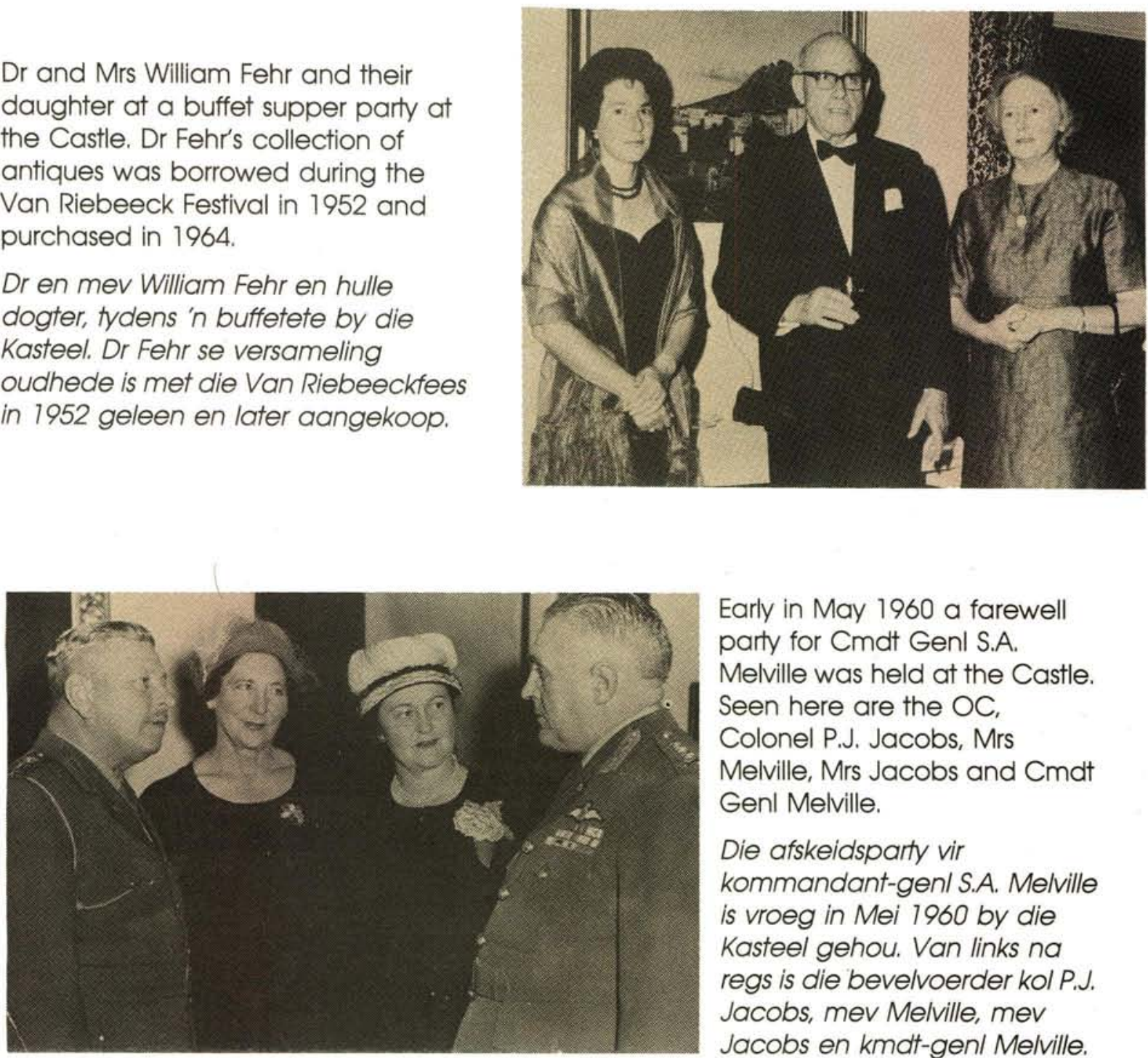

Early in May 1960 a farewell party for Cmat Genl S.A. Melville was held at the Castle. Seen here are the OC, Colonel P.J. Jacobs, Mrs Melville, Mrs Jacobs and Cmdt Genl Melville.

Die afskeidsparty vir kommandant-gen/ S.A. Melville is vroeg in Mei 1960 by die Kasteel gehou. Van links na regs is die bevelvoerder kol P.J. Jacobs, mev Melville, mev Jacobs en kmat-genl Melville. 


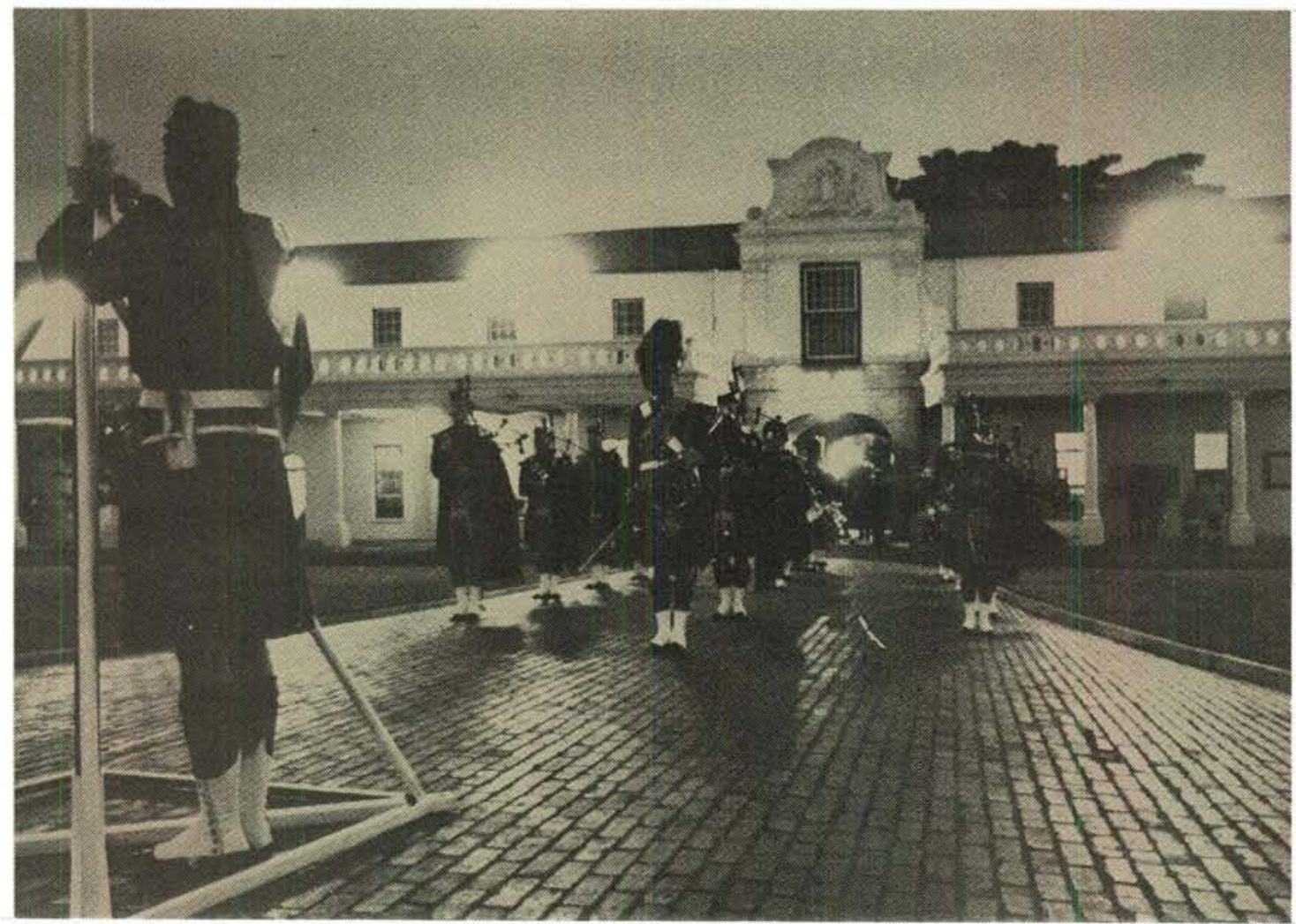

On the 150th Anniversary of the arrival of the 1820 settlers a Retreat Ceremony was t, va by the Cape Town Highlanders.

Tydens die 150ste herdenking van die aankoms van die 1820 Setlaars aan die Kaap, is 'n Vlaghysingseremonie deur die Cape Town Highlanders gehou.

Miss Sarah Goldblatt, centre, arrives at the Castle for a ceremony to mark the handing over of the "Vlaglied" to the SA Defence Force in 1973.

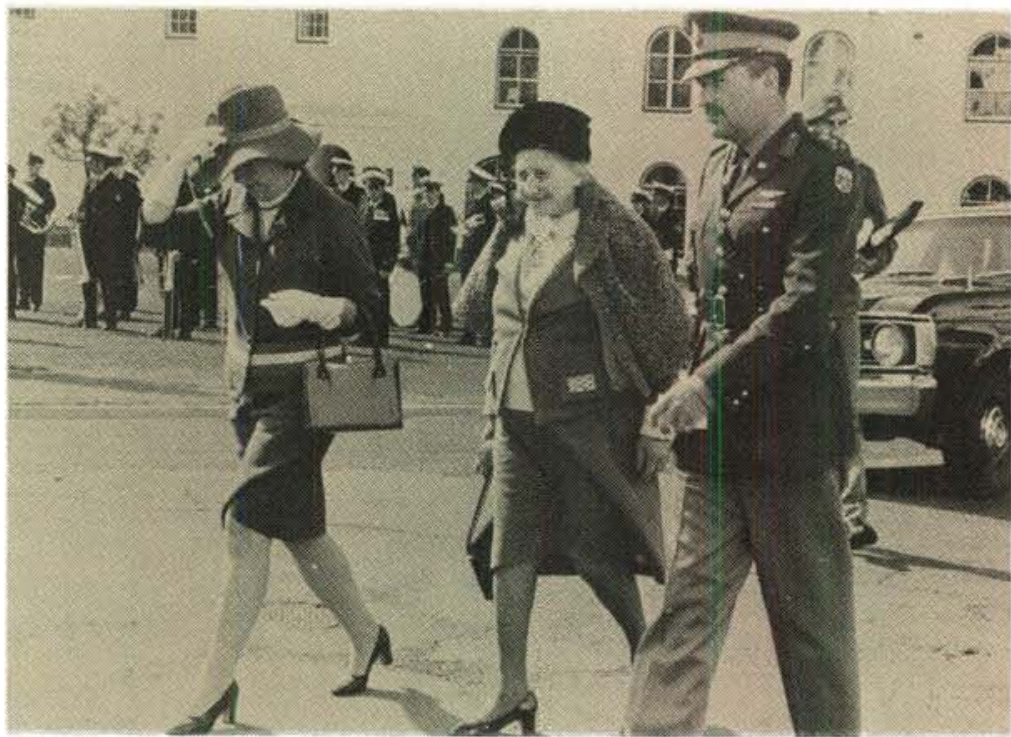

Mej Sarah Goldblatt (middel) arriveer by die Kasteel vir 'n seremonie waartydens die Vlaglied aan die SA Weermag oorhandig is in 1973. 


\section{Presentation of Medals, Decorations and Awards}

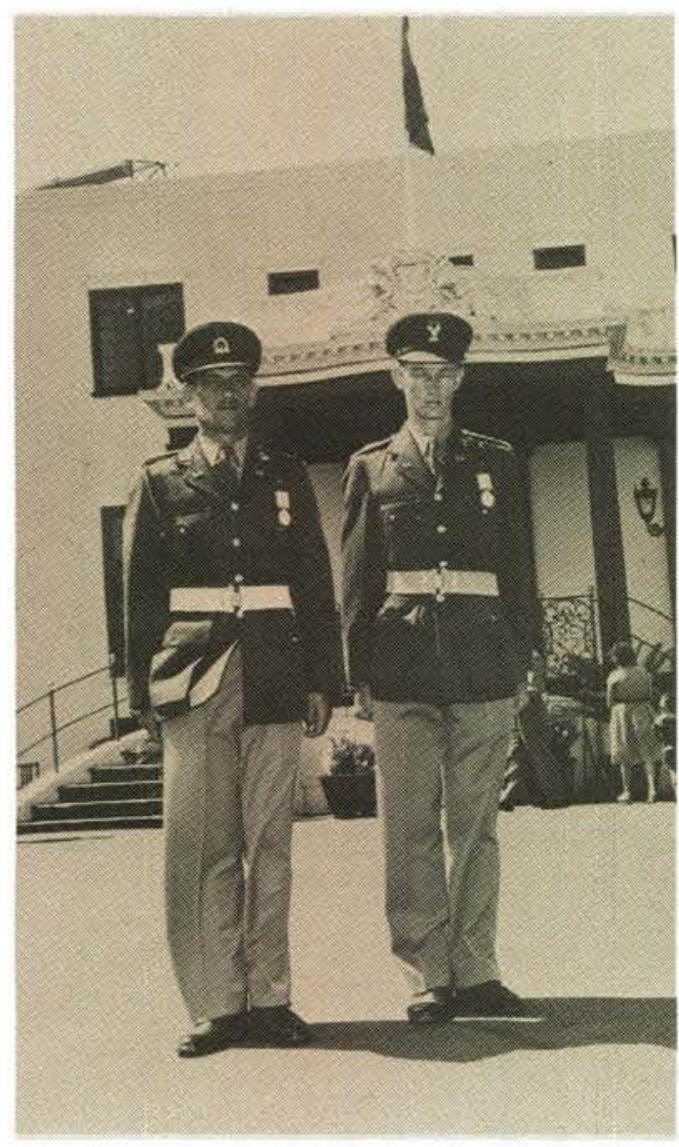

Brig M.A. de M. Malan is decorated with the Southern Cross Medal by Major-General H.A. Kotze at the Castle on the 29th August 1969.

Brig M.A. de M. Malan ontvang die Suiderkruismedalje van genl-maj H.A. Kotze op 29 Augustus 1969 by die Kasteel.

\section{Toekenning van Medaljes, Dekorasies en Eerbewyse}

Sergeant F.P. Stephens and Rifleman J.J.P. van Wyk after being decorated with the Louw Wepener Medal awarded for conspicuous courage in extreme danger by State President C.R. Swart on 26th January 1964.

Sersant F.P. Stephens en sktr J.J.P. van Wyk nadat die Louw Wepener Medalje vir voortreflike dapperheid tydens uiterste gevaar, op 26 Januarie 1964 deur Staatspresident C.R. Swart aan hulle oorhandig is.

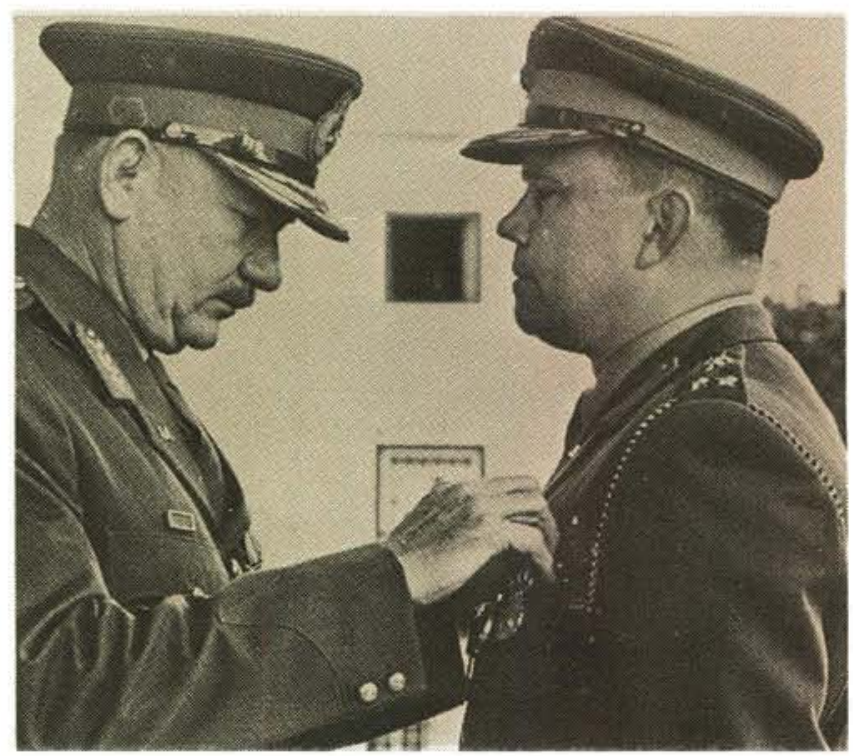


State President J.J. Fouché congratulates Major-General F.W. Loots after decorating him with the Star of South Africa in 1969. ViceAdmiral H.H. Bierman, then Chief of the Navy, looks on.

\section{Staatspresident J.J. Fouché wens} genl-maj F.W. Loots geluk met die ontvangs van die Ster van Suid-Afrika in 1969. Vise-admiraal H.H. Bierman, destydse Hoof van die Vloot, kyk toe.
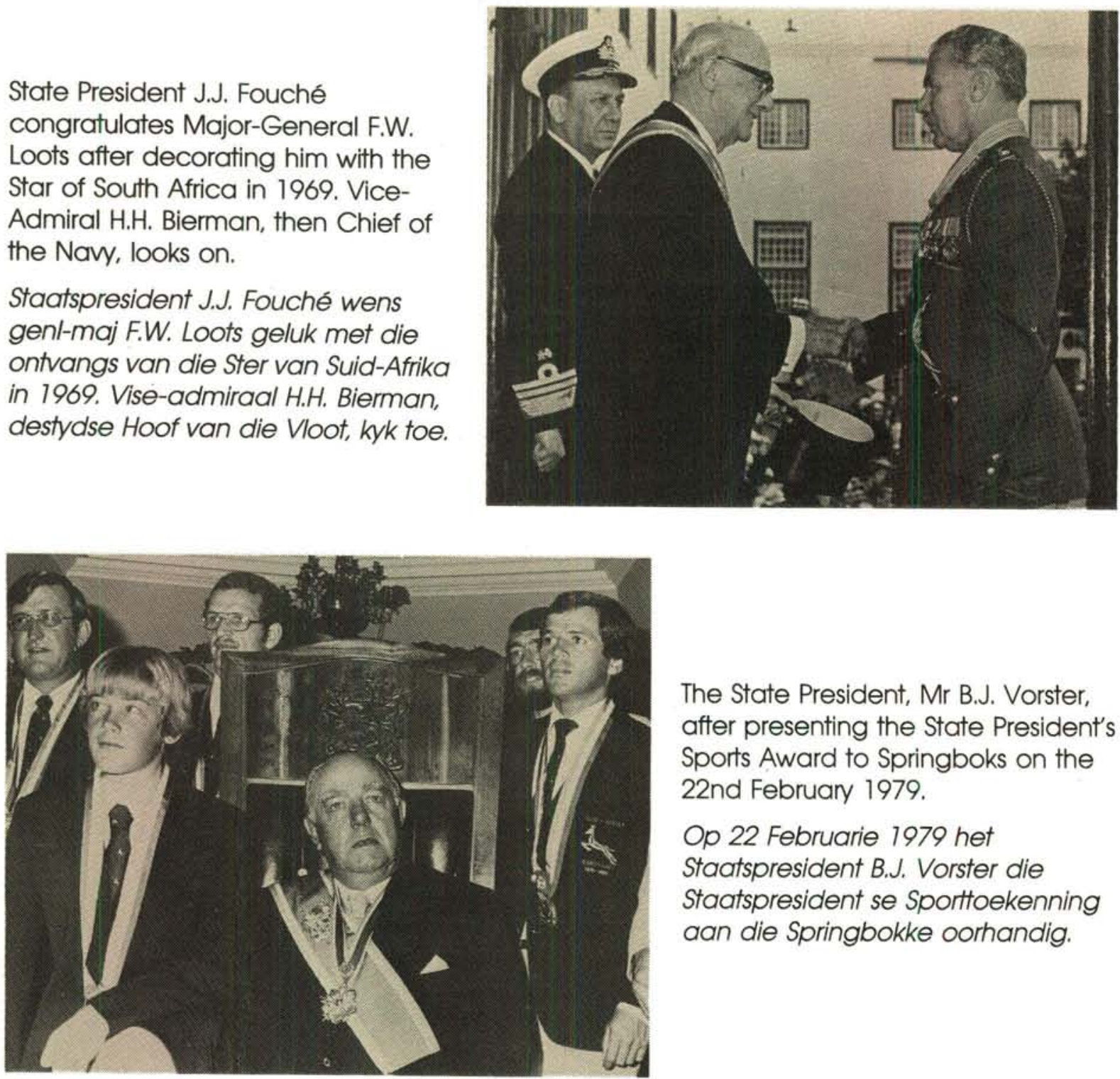

The State President, Mr B.J. Vorster, after presenting the State President's Sports Award to Springboks on the 22nd February 1979.

Op 22 Februarie 1979 het Staatspresident B.J. Vorster die Staatspresident se Sporttoekenning aan die Springbokke oorhandig.

The then Prime Minister, Mr P.W. Botha, Mr C. Eglin, then leader of the Opposition and Major General N.N. Webster, receive honorary membership of the Gunners' Council on 8th June 1979.

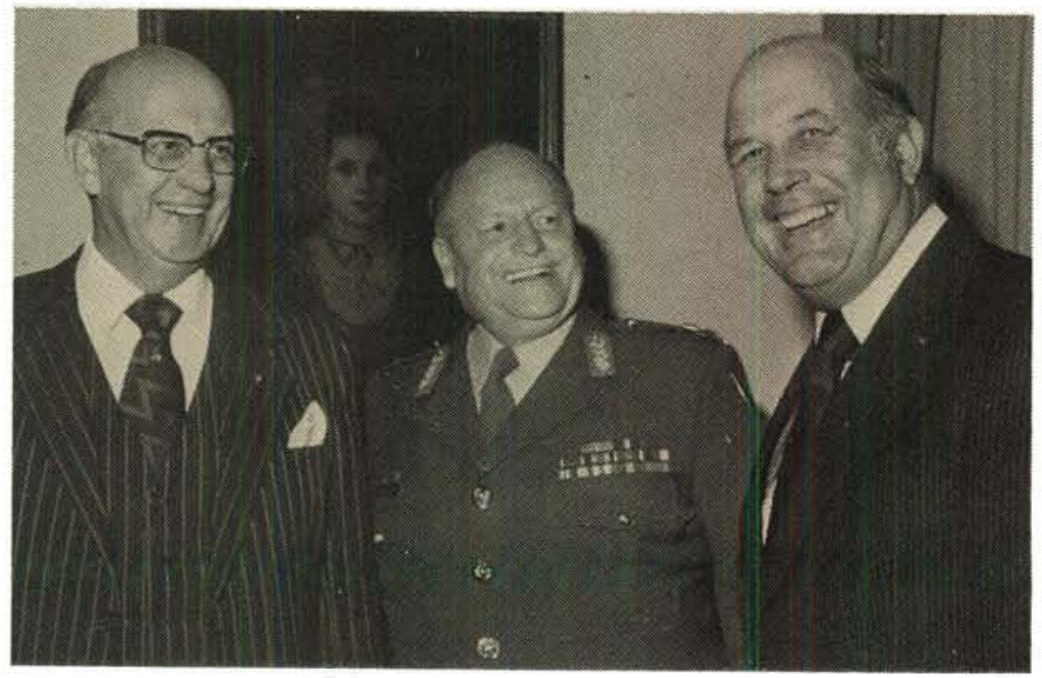

Die eertydse Eersteminister, mnr P.W. Botha, mnr C. Eglin, die toenmalige leier van die Opposisie en genl-maj N.N. Webster het op 8 Junie 1979 erelidmaatskap van die Gunners' Council ontvang. 


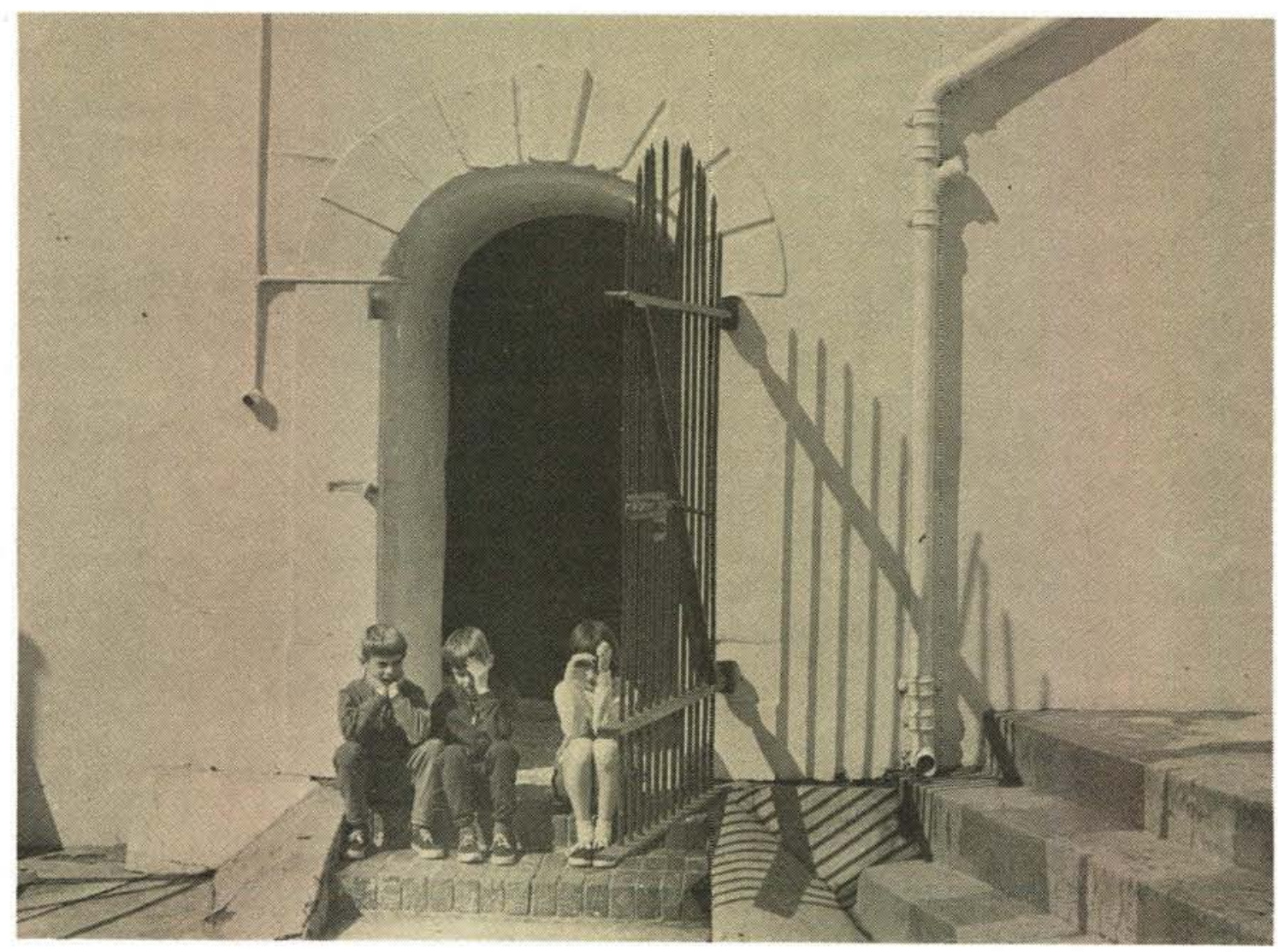

Entrance to the Cells, Katzenellenbogen bastion. On the left is a water tank. Ingang na die selle, Katzenellenbogen bastion. Aan die linkerkant is 'n watertenk. 


\section{The Dark Hole}

\section{Lt A.M. le Roux}

Against one of the walls of the bastion Katzenellenbogen a staircase runs down to the second courtyard. It is here that the Dark Hole, the most feared "room" in the Castle is to be found. A pitch dark, unventilated subterranean cell against which the health of no prisoner was equal for long.

The court of justice was seated in the Castle and prisoners who were sentenced, or sentenced to. die, were detained in the cells underneath Katzenellenbogen. If an accused refused to talk or admit that he committed a crime, he was often locked up in the notorious Black Hole for a time. Even threats to put prisoners on a diet of bread and water, to use the rack or to banish them to Mauritius were used. Accused were sometimes also tortured in the torture room to extract information from them.

This was necessary during the judicature of those years, as convictions could not be made without a confession. Confessions were mostly obtained with the aid of the rack in the Castle and the condemned were executed in the Leerdam bastion.

\section{Prisoners in the Hole}

In an effort to strengthen the Castle, W.A. van der Stel ordered additional defences to be erected. As a result of his poor management, it took longer than necessary and after his corruption came to light, he had those responsible arrested.

This resulted therein that one of the esteemed citizens of the community, Jacobus van der Heyden, was taken by a sergeant, a corporal and four men, "iujt de waght met halve picken, nevens den geweldiger scerpregter en drie of vier caffers in't donker gat gebragt". The procedure adopted by the governor was outrageous, as it was the custom that imprisonment was only applied in the case of "vise en sware dilenquanten, maar noijt den menschen tot straff aangewend is nie".

\section{Die Donker Gat}

Lf A.M. le Roux

Teen een van die mure van die bastion Katzenellenbogen loop ' $n$ stel trappe af tot by die tweede binneplaas. Dit is hier waar die Donker Gat - seker die mees gevreesde "vertrek" in die Kasteel - te vinde is. 'n Stikdonker, ongeventileerde, onderaardse sel waarteen geen gevangene se gesondheid lank bestand was nie.

Die geregshof het in die Kasteel sitting gehad en gevangenes wat gevonnis of ten dood veroordeel is, is in die selle onder die Katzenellenbogen aangehou. Wanneer ' $n$ beskuldigde nie wou praat of erken dat hy' $n$ misdaad gepleeg het nie, is hy dikwels 'n tydlank in die berugte Donker Gat opgesluit. Selfs die dreigemente om gevangenes op brood en water te sit; om die pynbank te gebruik of om hulle na Mauritius te verban, is gebruik. Beskuldigdes is soms ook in die folterkamer gemartel om 'n erkenning van hulle te $k r y$.

Dit was in daardie jare se regspleging nodig omdat teregstellings nie sonder 'n bekentenis uitgevoer kon word nie. Bekentenisse is meestal mbv die pynbank in die Kasteel gekry en terdoodveroordeeldes is in die bastion Leerdam tereggestel.

\section{Gevangenes van die Gat}

In 'n poging om die Kasteel te versterk het W.A. van der Stel bykomende verdedigingswerke laat aanlê. Vanweë sy swak bestuur het dit langer gevat as wat nodig was en nadat sy korrupsie aan die lig gebring is, het hy die verantwoordelike persone laat arresteer.

Dit het tot gevolg gehad dat een van die gesiene burgers van die samelewing, Jacobus van der Heyden, na sy verhoor deur 'n sersant, 'n korporaal en vier man "uijt de waght met halve pieken, nevens den geweldiger, scerpregter en drie of vier caffers in't donker gat gebracht". Die handelswyse van die Goewerneur was verregaande aangesien dit die gewoonte was dat opsluiting al- 
Imprisonment in the Hole was the worst penalty that could be imposed on a transgressor. No wonder that Van der Heyden, after a few days "in de grootste angst en benaauwdhijd des waerelds" became so ill that he eventually died.

Out of fear of what might happen, some prisoners immediately gave "satisfactory" answers. Adam Tas was imprisoned in the Castle by Van der Stel for 14 months. He spent one night in the Dark Hole after which he amended his accusation against the Governor to such an extent that he was imprisoned elsewhere in the Castle. Others had to spend weeks in unhealthy cells before they gave in. Jacques de Savoye and one Pieter de Meyer personally had to make the acquaintance of the Dark Hole.

Two other prisoners were already on a ship preparing to sail for Mauritius, before they signed the admission of guilt. In this manner the Governor blackmailed several prisoners as it best suited him.

\section{Bibliography}

1. RAS, A.C. Die Kasteel en andere vroee Kaapse vestingswerke, 1652-1713, Tafelberg Uitgewers (Edms) Bpk, Kaapstad, 1959.

2. Wêreldspektrum Deel 14, Ensiklopedie Afrikana (Edms) Bpk 1982. leen teenoor "vise en sware dilenquanten, maar noijt den menschen tot straff aangewend is nie".

Gevangehouding in die Gat was die ergste straf wat 'n oortreder te beurt kon val. Geen wonder dat Van der Heyden na 'n paar dae "in de grootste angst en benaauwdheyd des waerelds" so siek geword het dat hy uiteindelik oorlede is nie.

Uit vrees vir wat kan gebeur, het sommige gevangenes dadelik "bevredigende" antwoorde gegee. Adam Tas is deur Van der Stel vir 14 maande in die Kasteel opgesluit. Hy het een nag in die Donker Gat deurgebring en daarna sy aanklag teen die Goewerneur.so gewysig dat hy elders in die Kasteel opges/uit is. Ander moes eers weke in ongesonde selle deurbring voordat hulle wou ingee. Jacques de Savoye en ene Pieter de Meyer moes self met die Donker Gat kennis maak. Twee ander gevangenes was reeds op 'n skip wat op vertrek na Mauritius gestaan het, voordat hulle bekentenisse onderteken het. Op hierdie manier het die Goewerneur verskeie gevangenes afgepers soos wat dit hom pas.

\section{Bibliografie}

1. RAS, A.C. Die Kasteel en andere vroeé Kaapse Vestingswerke, 1652-1712. Tafelberg Uitgewers (Edms) Bpk, Kaapstad, 1959.

2. Wêreldspektrum Deel 14, Ensiklopedie Afrikana (Edms) Bpk, 1982 


\section{As Prison}

\section{As Gevangenis}

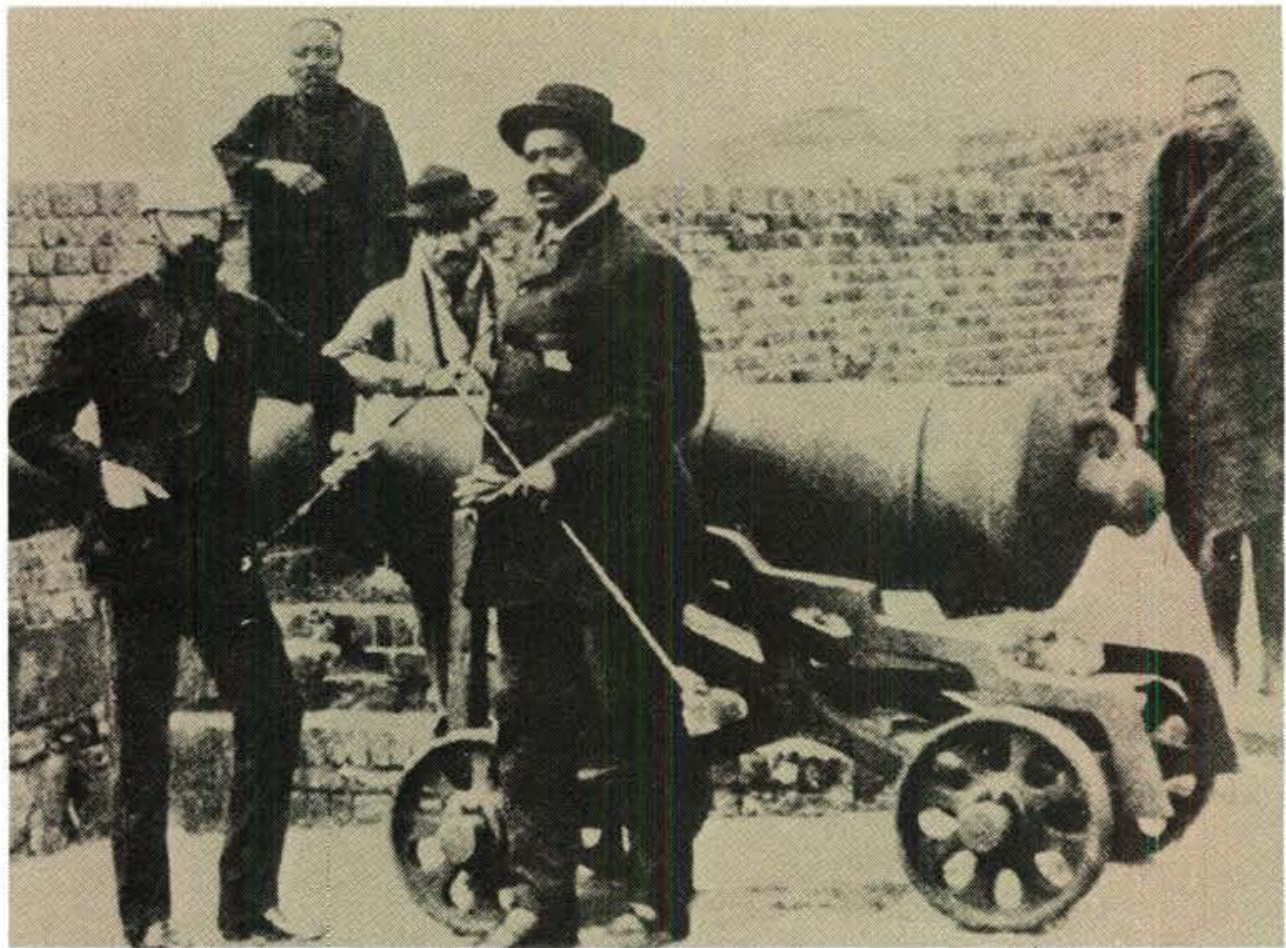

King Cetshwayo and his entourage were conveyed to the Castle on 15 September 1879 and were accommodated in the upstairs room in E Block nearest to the Provost Cells.
Koning Cetshwayo en sy gevolg is op 15 September 1879 na die Kasteel geneem en in die boonste kamers in E Blok naaste aan die Provoosselle gehuisves.
Entrance to the Provost cells in Katzenellenbogen in April 1952. King Cetshwayo's bathroom was on the left of the water tank.

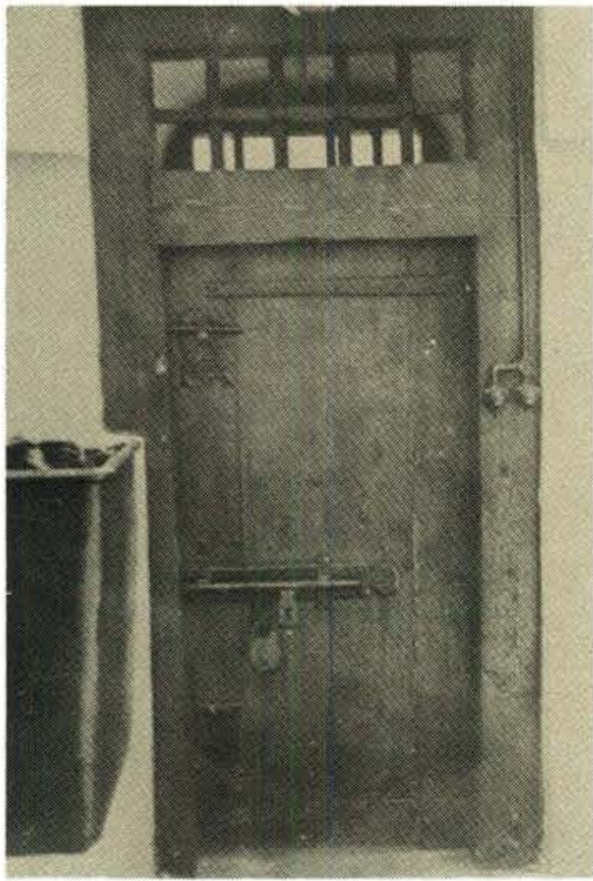

Ingang na die

Provoosselle in

Katzenellenbogen in April 1952. Koning Cetshwayo se badkamer was net links van hierdie watertenk. 


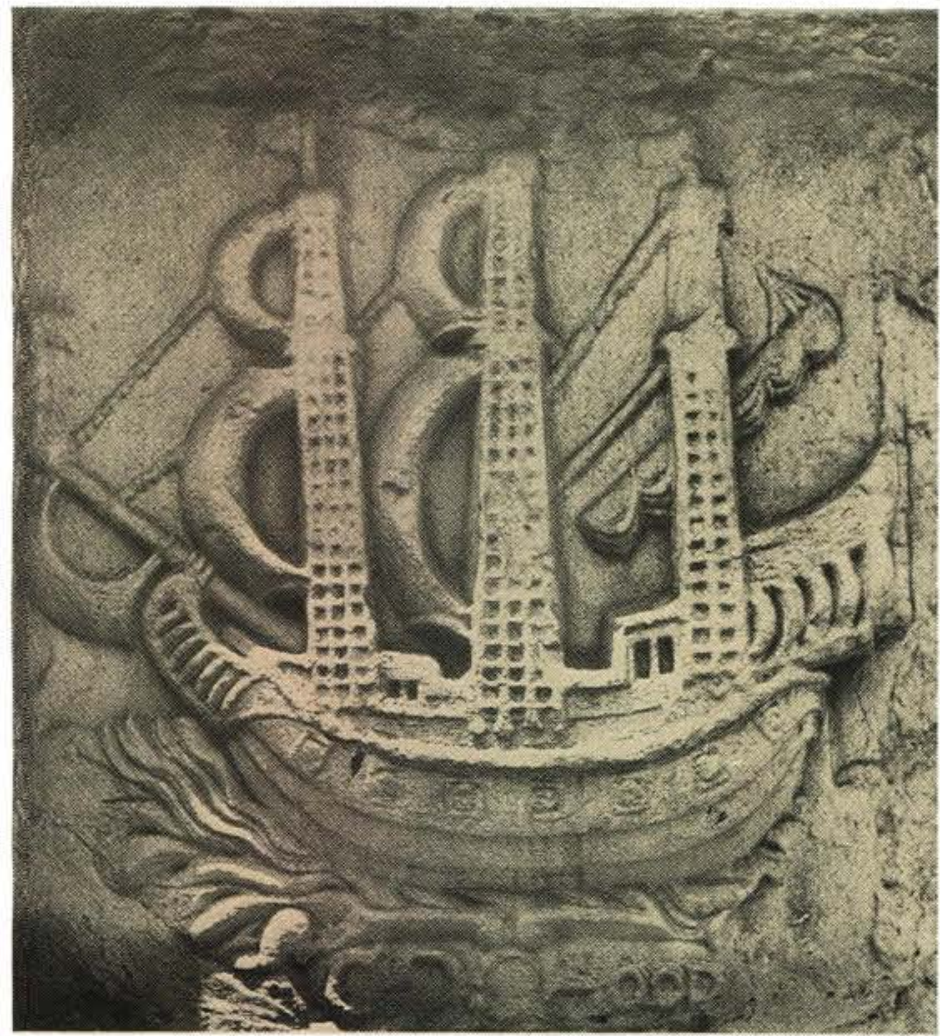

The seal of the Dutch East India Company carved in stone and mounted on the wall alongside the steps leading down to the cells in Katzenellenbogen. It may have come from Jan van Riebeeck's fort, later to be used to decorate the original entrance to the Castle, the watergate.

Die seell van die HOIK wat in steen uitgegraveer is, is te vinde langs die trappe wat afgaan na die selle in Katzenellenbogen. Dit is moontlik dat dit van Jan van Riebeeck se fort gekom het en later gebruik is om die oorspronklike ingang na die Kasteel te versier.

For many years it was thought that this dark room was the notorious Black Hole.

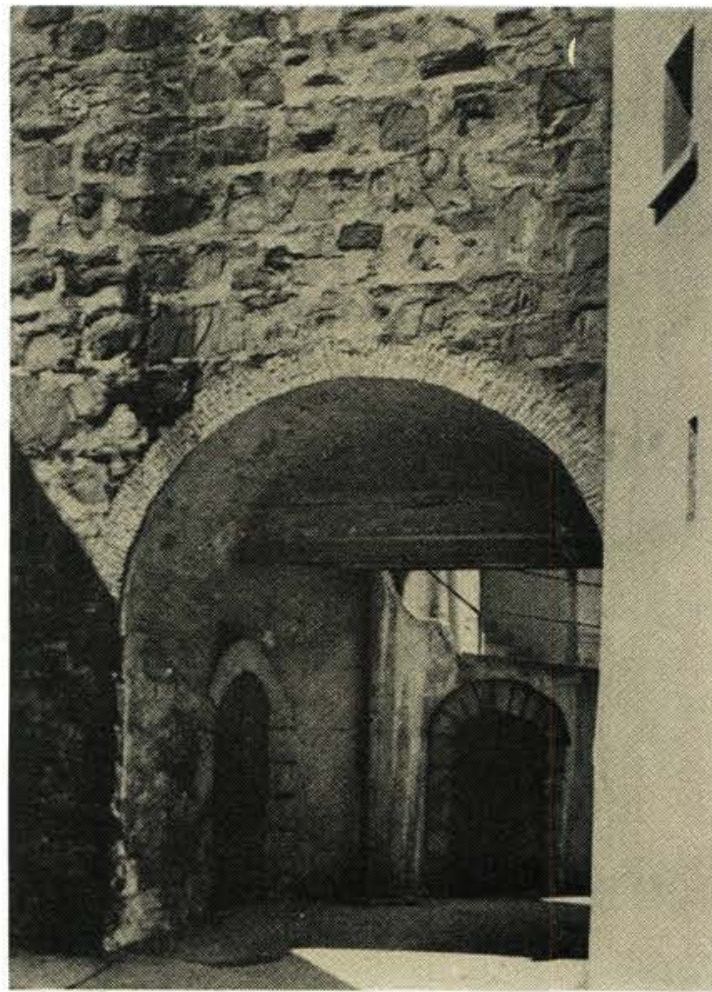

Daar is vir baie jare geglo dat dié donker kamer die berugte Donker Gat is. 


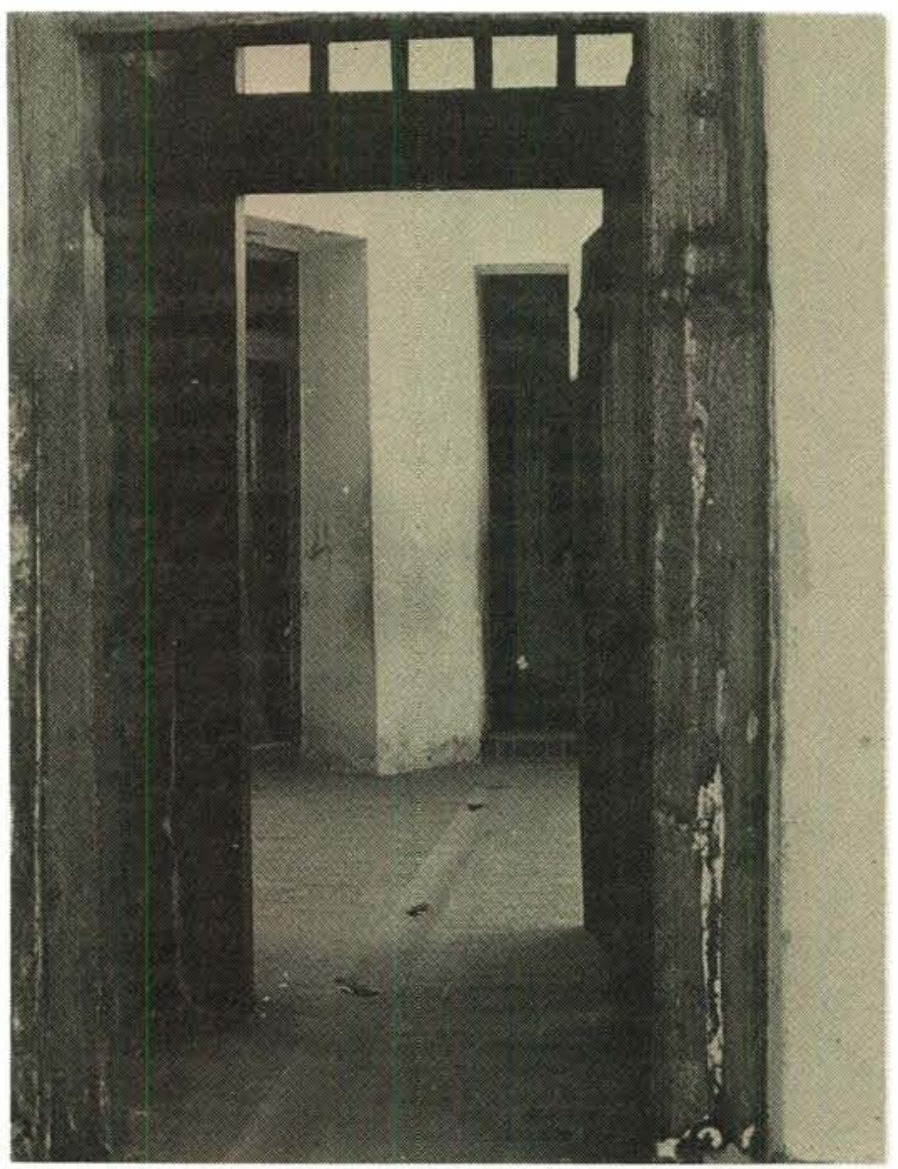

Entrance to the provost cells in Katzenellenbogen which were built in 1786 and designed by Captain L.M. Thibault. They were still in use in 1947.

Die ingang na die provoosselle in Katzenellenbogen wat deur kaptein L.M. Thibault ontwerp en in 1786 gebou is. Hierdie selle was in 1947 nog steeds in gebruik.

A reminder of how some prisoners at the Castle tried to while away the time. I. Hickey was a British soldier who received a $2 \frac{1}{2}$ year sentence for being absent without leave for two weeks in 1806.

'n Blik op hoe gevangenes in die Kasteel hulle tyd verdryf het. Hickey was 'n Engelse soldaat wat 'n $2 \frac{1}{2}$ jaar vonnis gekry het, nadat hy in 1806 twee weke afwesig was sonder verlof.

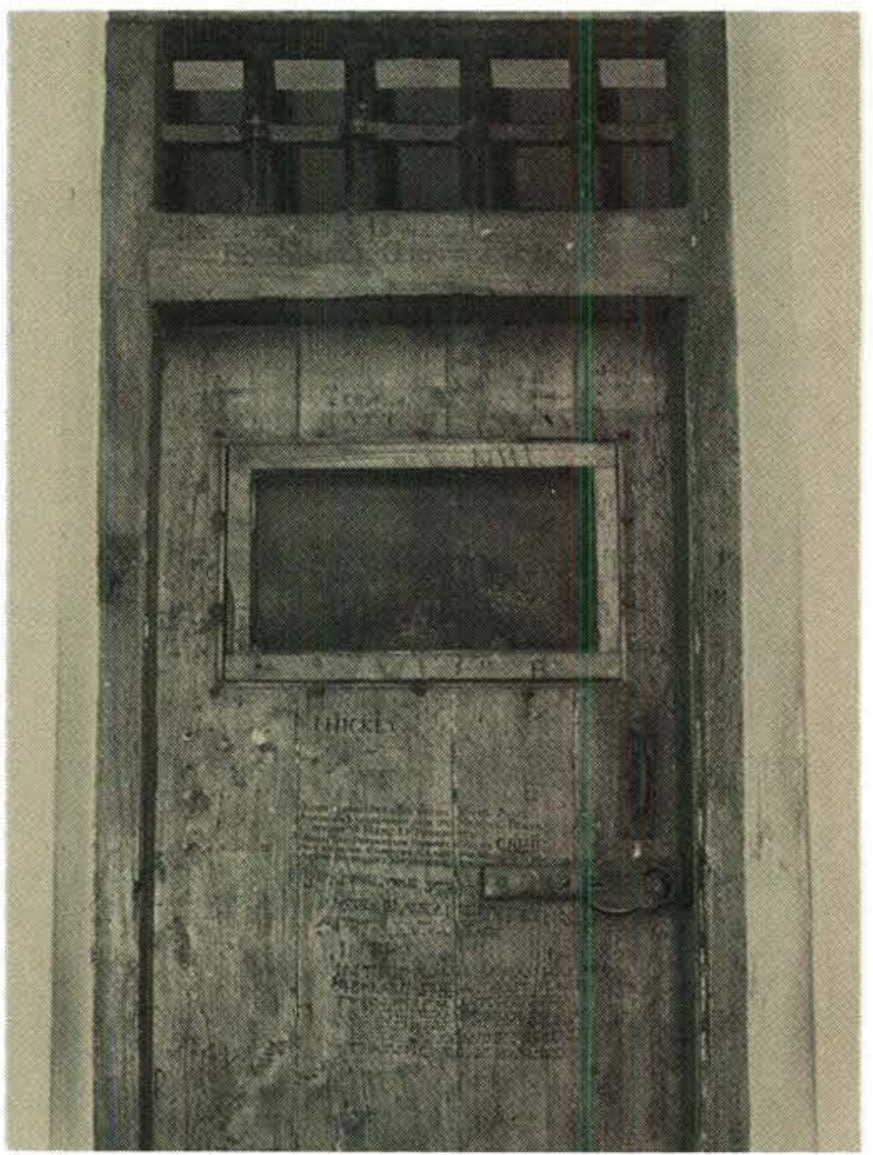




\section{The Castle's museums}

\section{Die Kasteel se museums}

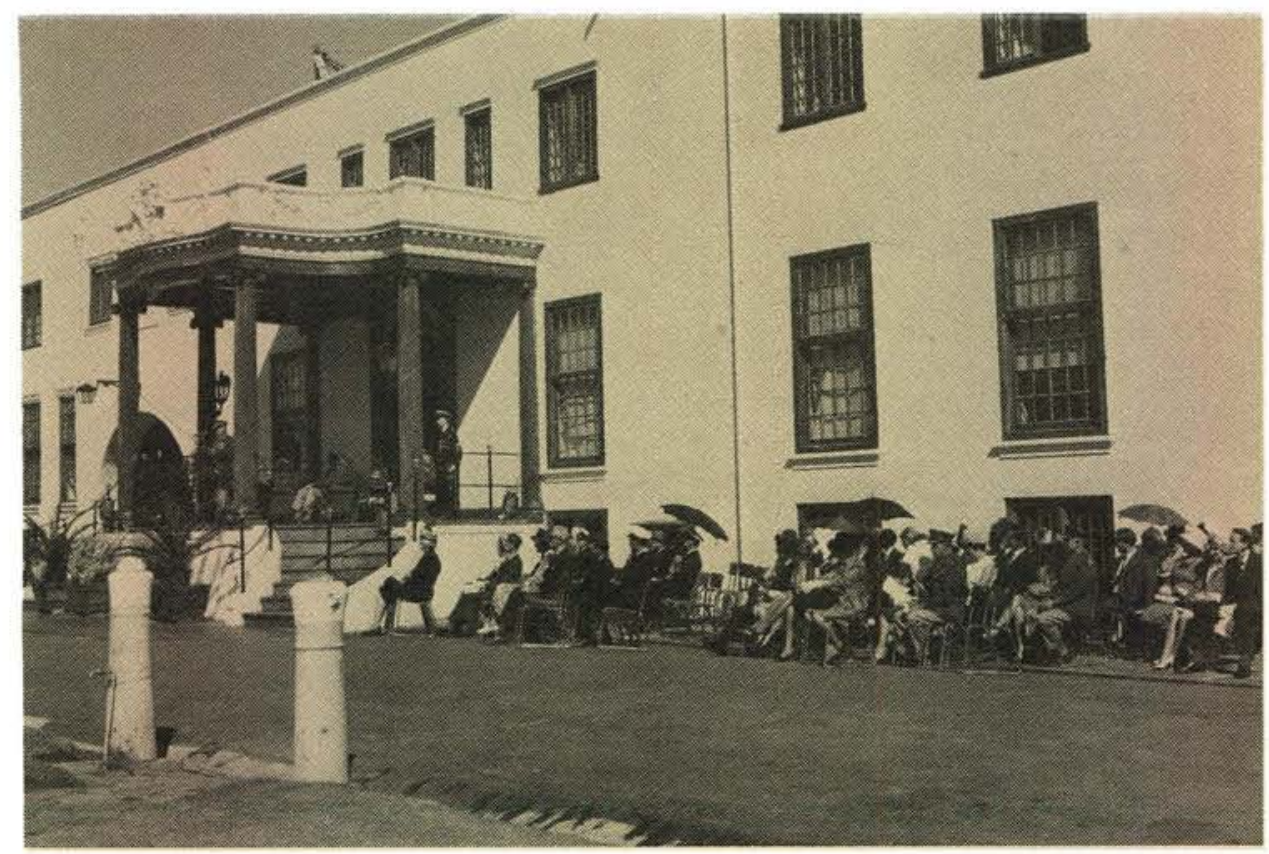

General Hiemstra delivering his speech at the opening of the Military Museum on 25 November 1966.
Generaal Hiemstra lewer sy toespraak tydens die opening van die Militêre museum by die Kasteel op 25 November 1966.

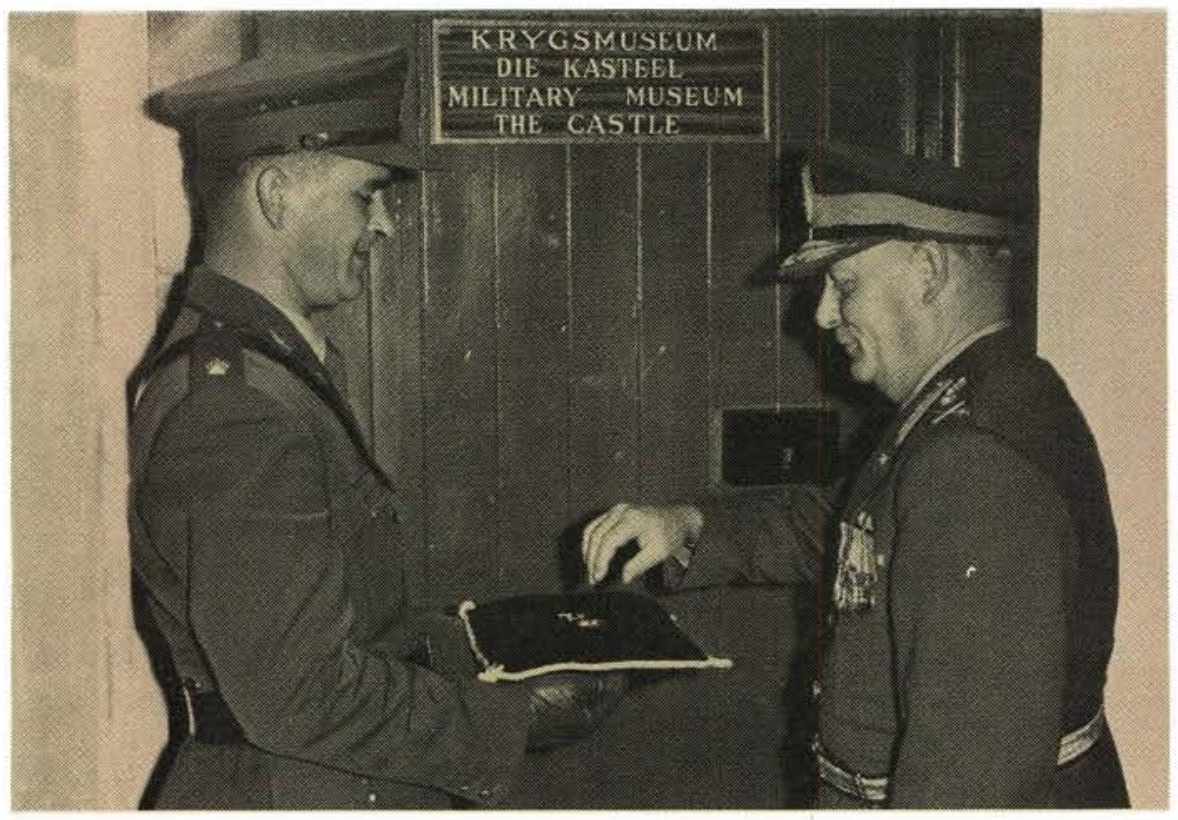

The opening of the Military Museum at the Castle by the Commandant General of the SA Defence Force, General R.C. Hiemstra. He receives the key of the Museum door from Major L.S. Kruger.
Die kommandant-generaal van die SA Weermag, genl R.C. Hiemstra, open die Militêre museum by die Kasteel. Hier ontvang hy die Museum se sleutel van maj L.S. Kruger. 


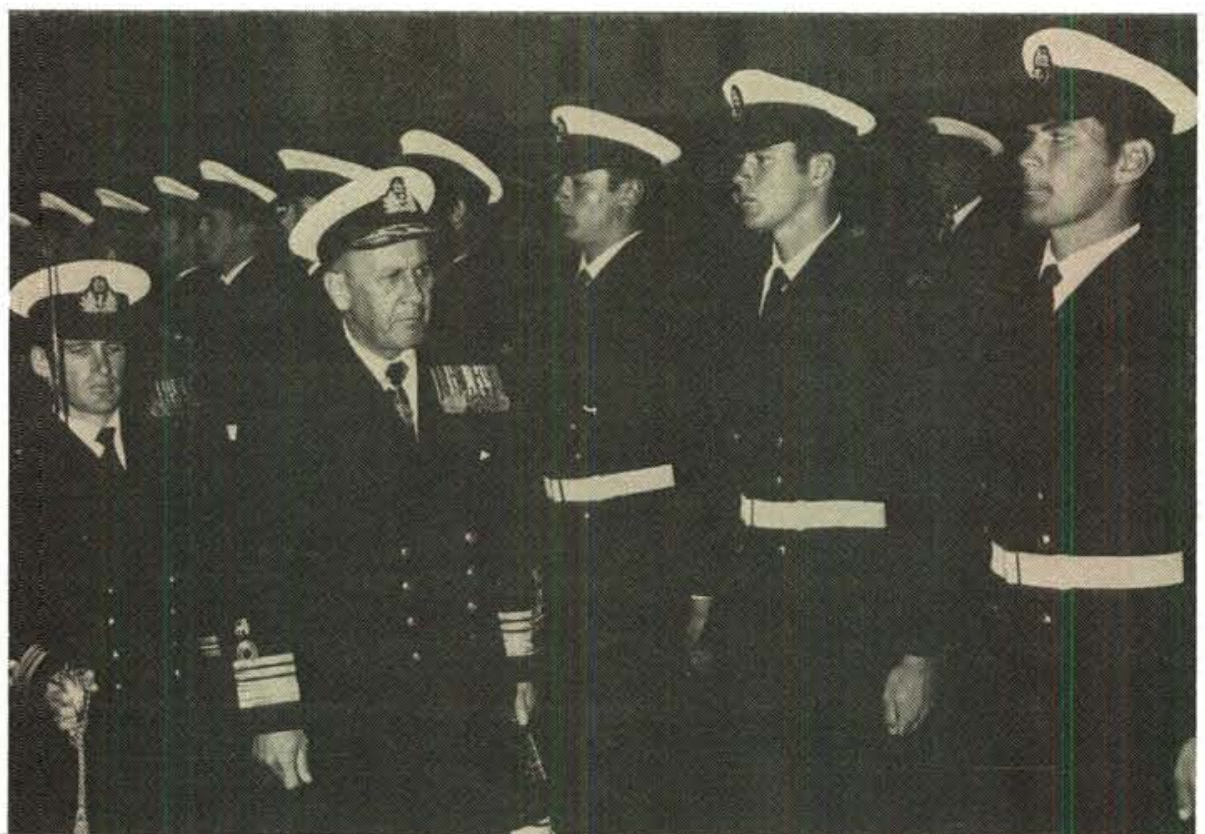

Vice-Admiral H.H. Bierman, SSA, OBE, Chief of the Navy, accompanied by Lt Cdr J.C. Reyneke, inspects a Naval Guard of Honour prior to the opening of the Maritime Museum at the Castle. On 18 May 1971.

Vise-admiraal H.H. Bierman, SSA OBE, Hoof van die Vloot, vergesel van Ht-kdr J.C. Reyneke, inspekteer 'n vlooterewag voor die opening van die Maritieme Museum by die Kasteel op $18 \mathrm{Mei} 1971$.

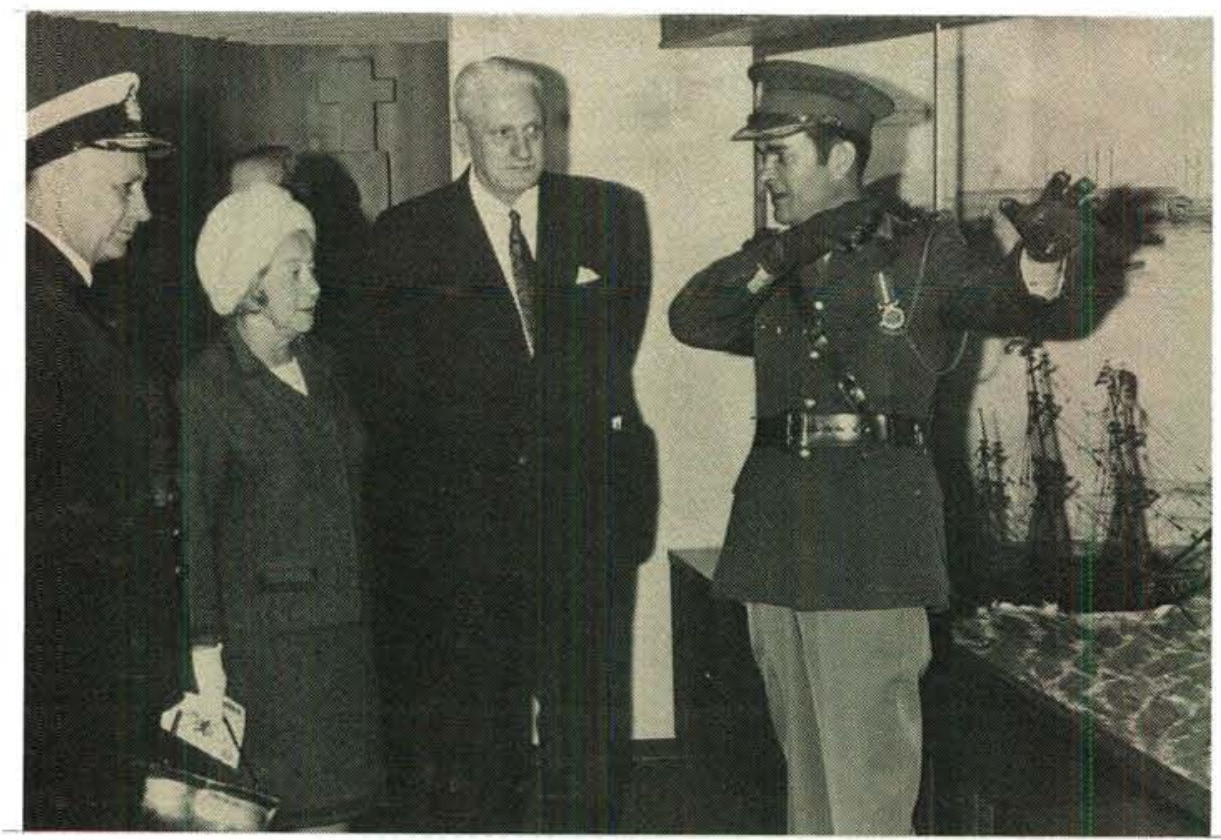

The opening of the Maritime Museum at the Castle. From left to right: ViceAdmiral H.H. Bierman who opened the Museum, Mrs Ferry, Councillor E. Ferry and Colonel L.S. Kruger.

Die opening van die Maritieme Museum by die Kasteel. Van links na regs: Vise-Admiraal H.H. Bierman wat die museum geopen het, mev Ferry, raadslid G.E. Ferry en kolonel L.S. Kruger. 